GRADISCA DE OLIVEIRA WERNECK DE CAPISTRANO

A vila nos textos de Alberti e Palladio

Tese apresentada ao Instituto de Arquitetura e Urbanismo da Universidade de São Paulo para obtenção do título de Doutora em Arquitetura e Urbanismo

Área de Concentração: Teoria e História da Arquitetura e do Urbanismo

Orientador: Professor Associado Joubert José Lancha 
AUTORIZO A REPRODUÇÃO TOTAL OU PARCIAL DESTE TRABALHO, POR QUALQUER MEIO CONVENCIONAL OU ELETRÔNICO, PARA FINS DE ESTUDO E PESQUISA, DESDE QUE CITADA A FONTE.

Capistrano, Gradisca de Oliveira Werneck de
C243a A vila nos textos de Alberti e Palladio / Gradisca de Oliveira Werneck de Capistrano; orientador Joubert José Lancha. São Carlos, 2014.

Tese (Doutorado) - Programa de Pós-Graduação em Arquitetura e Urbanismo e Área de Concentração em Teoria e História da Arquitetura e do Urbanismo -Instituto de Arquitetura e Urbanismo da Universidade de São Paulo, 2014.

1. vila. 2. Alberti. 3. Palladio. 4. tratados de arquitetura. I. Título. 


\section{FOLHA DE JULGAMENTO}

Candidata: Arquiteta e Urbanista Gradisca de Oliveira Werneck de Capistrano

Título da tese: "A vila nos textos de Alberti e Palladio".

Data da defesa: 14/11/2014

Comissão Julgadora:

Prof. Dr. Joubert José Lancha (Orientador)

(Instituto de Arquitetura e Urbanismo - USP)<smiles>CC(C)(C)C1CCCCC1C#N</smiles>

Prof. Dr. Francisco José Barata Fernandes

(Faculdade de Arquitectura- Universidade do Porto)

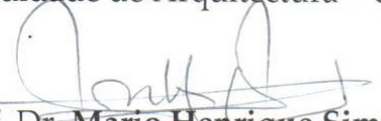

Prof. Dr. Mario Henrique Simão D'Agostino

(Faculdade de Arquitetura e Urbanismo - USP)

\section{Prof. Dr. Paulo Cesar Castral}

(Instituto de Arquitetura e Urbanismo - USP)

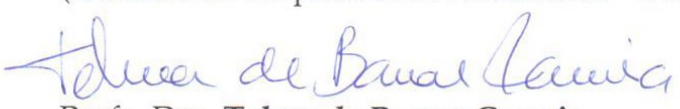

Profa. Dra. Telma de Barros Correia

(Instituto de Arquitetura e Urbanismo - USP)

\section{Resultado:}

APROUQA DA
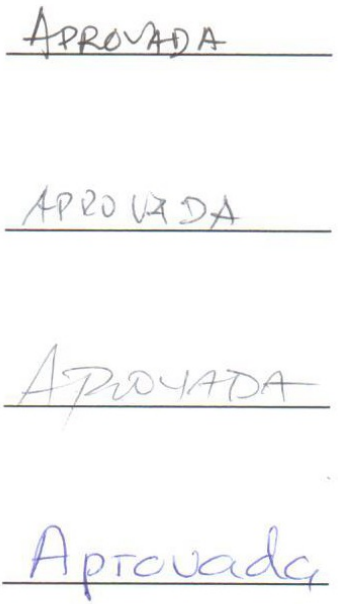

Coordenador e Presidente da Comissão de Pós-Graduação do Programa de PósGraduação em Arquitetura e Urbanismo: Prof. Dr. Márcio Minto Fabrício 

Para Giovanni 



\section{AGRADECIMENTOS}

Ao meu orientador, Joubert Lancha, pela paciência, dedicação e atenção com que me acompanhou e auxiliou na realização dessa pesquisa.

Aos professores Marcos F. Barnabé (in memoriam), Jorge Daniel de Melo Moura e Ricardo Dias Silva, da Universidade Estadual de Londrina, que despertaram em mim o interesse pela pesquisa e sempre me motivaram a buscar conhecimento.

Ao meu esposo, Giovanni, que esteve sempre ao meu lado e me apoiou, em todos os momentos e todas as mudanças por que passamos durante desenvolvimento desse trabalho.

Aos meus pais, Wael e Rui, que desde cedo me motivaram a estudar e a apreciar a leitura e a escrita. E que, mesmo comigo a distâncias cada vez maiores, sempre fizeram o possível para me incentivar e me acompanhar a cada dia.

Aos meus avós, Walter e Elza, e minhas irmãs, Milena e Anä̈s, sempre muito carinhosos e presentes.

Aos meus amigos, sempre pacientes e compreensivos nas muitas vezes em que não pude estar presente.

À Universidade de São Paulo, pela oportunidade de realizar o doutorado e toda a estrutura que encontrei para isso.

À Pró-Reitoria de Pesquisa da USP, pela bolsa concedida dentro do convênio USP-UP, que tornou possível a realização de um período de estudos na FAUP.

Aos professores e funcionários do Instituto de Arquitetura e Urbanismo - USP, por todo apoio durante o desenvolvimento desse trabalho.

À Capes, pelos meses em que concedeu bolsa de doutorado no início do desenvolvimento desse trabalho. 



\section{RESUMO}

CAPISTRANO, G. de O. W. de. A vila nos textos de Alberti e Palladio. 2014. 247p. Tese (Doutorado) - Instituto de Arquitetura e Urbanismo, Universidade de São Paulo, São Carlos, 2014 .

Alberti e Palladio foram dois dos principais nomes na constituição dos modelos de vilas que caracterizaram o Renascimento italiano. Enquanto Alberti, em seu De re aedificatoria, estabeleceu as bases e a fundamentação teórica sobre o tema, no início do período, Palladio com I Quattro Libri dell'Architettura, sistematizou um repertório formal que - tornou responsável pela difusão do modelo ao redor do mundo. Tendo-se em vista a importância da contribuição de ambos os autores e considerando que Palladio leu o tratado de Alberti, foi feito um estudo comparativo desses dois modelos de vila, visando detectar suas aproximações e divergências. Partindo-se da exposição do tema no corpo dos tratados e passando pelas definições do termo vila são abordados diversos aspectos da argumentação dos dois autores. Considerando a grande contribuição de Alberti e Palladio no campo da representação gráfica da arquitetura e do processo intelectual de projeto, foi discutida a relação desses dois temas, tanto na composição quanto na apresentação das vilas (especificamente no tratado paladiano). São analisadas ainda, o estabelecimento das hierarquias que são utilizadas na adequação das vilas à classes sociais de seus proprietários, a setorização proposta na organização da vila e da casa de vila e, por fim, a compartimentação desses edifícios. Mesmo considerando que os dois autores leram Vitruvio, de onde poderiam ter surgido diversos pontos que apresentam em comum, deve-se considerar que, para o projeto e a concepção das vilas, o texto de Vitruvio foi de pouca utilidade. Sendo assim, é surpreendente e também reveladora a semelhança que se percebe nas vilas de Alberti e Palladio. Em diversos trechos dos tratados, os discursos são tão próximos que parecem complementares, como também se pode utilizar projetos paladianos para exemplificar indicações teorizadas por Alberti. Esse trabalho não pretende esgotar o argumento, mas verificar a existência de uma relação entre a vila para ambos e, com essa relação mostrando-se tão forte, superaram-se todas as expectativas iniciais.

Palavras-chave: vilas, tratados de arquitetura, Leon Battista Alberti, Andrea Palladio 



\section{ABSTRACT}

CAPISTRANO, G. de O. W. de. The villa in the writings of Alberti and Palladio. 2014. 247p. PhD Thesis - Instituto de Arquitetura e Urbanismo, Universidade de São Paulo, São Carlos, 2014 .

Alberti and Palladio were two of the leading names in the establishment of models for villas, which characterized the Italian Renaissance. At the beginning of the Renaissance period, Alberti in his De Re Aedificatoria established the foundation and the theoretical background of the subject. Afterward Palladio, in his I Quattro Libri Dell'Architettura, systematized a set of formal rules that made him responsible for the diffusion of a general model of villa around the world. Bearing in mind the importance of the contribution of both authors and considering that Palladio read Alberti's treatise, we made a comparative study of these two models of villa, in order to detect their similarities and differences. Several aspects of both authors' arguments are addressed, starting from the development of the subject in the body of the treaties and including the different definitions of the term villa. Given the important contributions of Alberti and Palladio in the field of graphic representation of architecture and intellectual process of project, the relationship between these two topics was discussed, both in the composition and in the presentation of villas (specifically in the Palladian treaty). Furthermore, we analyzed the establishment of hierarchies used in adapting the villas to the social class of their owners; we investigated the sections proposed for the organization of the villa and, finally, we examined the partitions of these buildings. Although the two authors read Vitruvius, who could have provided them with a common theoretical background, it must be stressed that Vitruvius's writings were of little use in the conception and project of villas. Therefore, it is surprising and revealing the resemblance noticed in the villas of Alberti and Palladio. In different parts of the treaties, discussions are so close that they seem complementary. Besides, Palladian projects can also be used to exemplify indications theorized by Alberti. The present study does not bring to an end the discussion; instead, it intends to check the existence of a relationship between the ideas of in both authors. We demonstrate that this relationship is actually strong, overcoming all the initial speculations of tight connections.

Keywords: villa, architecture treaties, Leon Battista Alberti, Andrea Palladio 



\section{LISTA DE FIGURAS}

Figura 1 - Ateliê de Peter Parler, corte da Catedral de Praga, cerca de 1430. Fonte: Ackerman (2003, p.39). p.35

Figura 2 - Detalhe do projeto para o Campanário da Catedral de Florença, primeiro quarto do século XV. Fonte:Ackerman(2003,p.43).p.38

Figura 3 - Leonardo da Vinci. O Homem Vitruviano. A proporção das partes é igual ao número de ouro ( $\Phi)$. Fonte: Andrade (2008, p.5) . p.40

Figura 4 - Ruínas de Villa Iovis (esq.), situada em Capri. Uma das doze residências de Tibério (42 a.C a 37 d.C). p.61.

Figura 5 - Ruínas de vila em Pompeia, onde se vê a paisagem ao fundo (dir.). p.61

Figura 6 - Reconstrução em planta e perspectiva da Villa Laurentinum, de Plínio o Jovem. Fonte: Ackerman (1992, p.66). p.63

Figura 7 - Reprodução da vila romana de Boscoreale. Fonte: Ackerman (1992, p.55) p.66

Figura 8 - Representação da Villa Medici Trebbio, por Giusto Utens. Fonte: Trebbio utens. Con licenza Public domain tramite Wikimedia Commons (sup.). p. 82

Figura 9 - Representação da Villa Medici Cafaggiolo, por Giusto Utens (inf.). Fonte: Con licenza Public domain tramite Wikimedia Commons (sup.) p.82

Figura 10 - Villa Poggio a Caiano, representação de Giusto Utens, 1599-1602. Fonte: Beltramini;Burns (2010, p.223). p.85.

Figura 11 - Planta da Villa di Poggioreale publicada no tratado de Serlio ${ }^{1}$. Fonte: Beltramini; Burns (2010, p.231). p.89.

Figura 12 - Cortile del Belvedere. Fonte: Burns (2012, p.135). p.89.

Figura 13 - Página onde é apresentado o projeto da Villa Pisani

Montagnana, no Livro II. Fonte: Palladio Livro II, Cap. XIIII (1570, p.51). p.117.

Figura 14 - (esq.) Página 35v do Taccuino Senese, de Giuliano da Sangallo. Fonte: Biblioteca Digital Mundial, disponível em: <http//: http://www.wdl.org/pt/item/10597/view/1/72/>. p.133.

Figura 15 - (dir.) Página do Livro IV de Palladio. Fonte: Palladio (1570, p.106). p.133.

Figura 16 - Detalhe das orientações para o projeto segundo a ordem Dórica, contendo capitel e entablamento. Fonte: Palladio, Livro I, Cap. XV (1570, p.25). p.134.

\footnotetext{
1 Ainda que Serlio não tenha conhecido a Villa di Poggioreale pessoalmente, conheceu os desenhos que Baldassare Peruzzi fez da vila após visitá-la e publicou-os em seu tratado, aumentando seu alcance. (Burns, 2012, p.51).
} 
Figura 17 - Detalhe do capitel e entablamento de Ordem Coríntia encontrados no Tempio de Marte Vendicatore. Fonte: Palladio: Livro IV, Cap. XVII. (1570, p.20). p.134.

Figura 18 - Representação esquemática das fachadas das vilas apresentadas no tratado. Em preto, as vilas dos proprietários de terra firme e em vermelho as vilas dos proprietários venezianos. p.142.

Figura 19 - Villa Godi, projeto apresentado no tratado (sup) p p.145.

Figura 20 - vista da fachada atual (inf.). p.145.

Figura 21 - Página do tratado em que é apresentado o projeto da Villa Barbaro, com destaque para o volume que se estende à frente do corpo principal. p.148.

Figura 22 - Vista lateral da vila mostrando o avanço do corpo central em relação à loggia lateral. p.148.

Figura 23: Detalhe da arquitrave da Vila Godi, onde se percebe a utilização de madeira revestida com estuque. p.150.

Figura 24: Colunas de tijolos na loggia da Villa Foscari. p.150.

Figura 25 - Planta esquemática da Villa Capra (sup.) e da Villa Trissino, em Meledo (inf.). p.154.

Figura 26 -Duas das páginas do tratado onde Palladio apresenta modelos de escadas (inf.). Fonte: Palladio (1570, Livro I, p.62-63). p.159.

Figura 27 - Escadas de acesso ao edifício residencial da Villa Barbaro (esq). p.160.

Figura 28 - Rampa de acesso ao edifício residencial da Villa Emo (dir). p.160.

Figura 29 - Vista a partir da sala principal da Villa Godi, com as aberturas internas alinhadas (esq.). p.163.

Figura 30 - Vista a partir de um dos cômodos internos da Villa Godi, com aberturas internas e externas alinhadas (dir.). p.163.

Figura 31 - Átrio de quatro colunas, corte e planta. Fonte: Palladio $(2009, \mathrm{p} .96)$. p.170.

Figura 32 - Átrio coríntio no Convento della Carità, em Veneza. Palladio (2009, p.98).p.173.

Figura 33 - Detalhe do Átrio coríntio no Convento della Carità, em Veneza. p.174.

Figura 34: Síntese das formas principais descritas por Alberti (Azul) e Palladio (amarelo) e aquelas que são referidas pelos dois autores (verdes). Fonte: Adaptado de Almeida (2005) . p.179.

Figura 35 - Acima as proporções utilizadas na composição da Villa Godi - Todos os cômodos guardam as mesmas proporções entre seus lados. Abaixo as proporções utilizadas na compartimentação da Villa Foscari Destaque para a relação de 3:8, segundo a qual é composta a loggia. p. 180 . 


\section{LISTA DE TABELAS}

Tabela 1 - Compilação das versões do tratado de Alberti nos diversos idiomas em que foi publicado - pela primeira vez - até 2011. Fonte: Adaptado de $\mathrm{AMO}^{2}$. p.18

Tabela 2 - Compilação dos tratados de arquitetura desenvolvidos no arco temporal do Renascimento. Adaptado de Evers (2003). p.53

Tabela 3 - Todas as vilas projetadas por Palladio em ordem cronológica. *data estimada; **cerca de; Fonte: Adaptado de Puppi (1999).p.101

Tabela 4 - Vilas apresentadas no tratado na ordem definida por

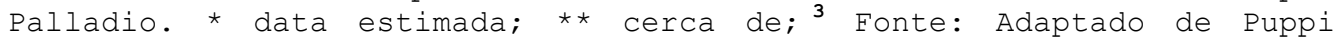
(1999). P.115-116

Tabela 5 - Síntese da classificação hierárquica dos proprietários dos homens para Vitruvio, Alberti e Palladio.p.139

2 Amo (1988).

3 As datas foram obtidas no Cisapalladio, e estão disponíveis em: $<$ http://http://mediatecapalladiomuseum.org/palladio/opere.php?tipologia=7\&S=c\&S $\underline{\mathrm{D}}=\mathrm{A} \& \mathrm{~V}=1 \& \mathrm{RN}=12 \& \mathrm{TR}=33 \& \mathrm{P}=1>$, acesso em 09/04/2014. 



\section{SUMÁRIO}

Introdução p.19

1. Produção arquitetônica na Itália renascentista $\mathbf{p . 2 7}$

O desenho de arquitetura p.33

O retorno a Vitruvio $\mathbf{p . 4 2}$

A arquitetura no Renascimento $\mathbf{p . 4 5}$

Os tratados e a profissão de arquiteto $\mathbf{p} .49$

2. Desenvolvimento do território e surgimento das vilas p.55

Viver no campo na Antiguidade Clássica $\mathbf{p . 5 7}$

Alberti e as vilas p.68

Florença e as primeiras vilas Médici p.79

A difusão das vilas $\mathbf{p} . \mathbf{8 7}$

As vilas vênetas p.91

Palladio e o Vêneto $\boldsymbol{p} .95$

3. A vila para Alberti e Palladio p.105

A organização do tratado e as vilas p.105

De re Aedificatoria p.105

I Quattro Libri dell'Architettura p.114

Definições de vila p.118

Escolha do lugar p.122

Processo de Projeto e Representação Gráfica na Arquitetura p. 127

Hierarquia social - Adequação das vilas aos proprietários p.135

Compartimentação e setorização $\mathbf{p} .151$

Compartimentação e dimensionamento p. 166

Loggia $\mathbf{p} .166$

O seio da casa $p .167$

Stanze p.174

Aberturas p.174

Proporções e Harmonia p.176

4. Considerações finais p.185 p.185

Referências p.191 
Apêndice A - Tradução da autora para Villa, de Leon Battista Alberti p.199

Apêndice B - p.203 


\section{Introdução}

Desde que, no Renascimento, os tratados de arquitetura foram reconhecidos como importantes veículos de comunicação e transmissão do conhecimento, nos períodos sucessivos a influência que eles exerceram nos profissionais da área foi variável. Em um contexto de retorno ao Classicismo, que marcou - Renascimento nas mais diversas áreas, os arquitetos desse período reencontraram o tratado de Vitruvio e não só o estudaram como também tiveram-no como base para conceber seus próprios tratados de arquitetura.

A pesquisa pictórica e a teorização filosófica criaram, contemporaneamente, os pressupostos para uma profunda mudança das concepções espaciais do ambiente físico e, consequentemente, da arquitetura ${ }^{1}$.

A reapropriação do texto de Vitruvio pelos humanistas e, especialmente, sua reproposição, a partir do De re Aedificatoria de Leon Battista Alberti, favoreceu um imponente florescimento das reflexões teóricas acerca do fazer arquitetônico.

O tratado de Alberti marcou o início da produção teórica dos arquitetos do Renascimento e a sistematização dos conhecimentos envolvidos na produção da arquitetura, que passava por grandes transformações. Assim como ocorria com todas as artes figurativas, a arquitetura também buscava sua inclusão no rol de artes liberais e o De re Aedificatoria contribuiu para isso, com a proposição de um corpus teórico acerca das atribuições do arquiteto, destacando sua vertente intelectual.

- Renascimento transpôs os limites da península italiana ${ }^{2}$ e, no decorrer do século XVI e XVII, os tratados começaram a se popularizar e se espalhar pela Europa $^{3}$, chegando inclusive à

\footnotetext{
1 Furnari (1993, p.175).

2 Nesse momento a Itália ainda não existia enquanto Estado Nacional, tendo significado apenas enquanto denominação geográfica. O território italiano durante o arco temporal compreendido nessa pesquisa era subdividido em vários pequenos reinados, alguns dos quais passaram por períodos de dominação estrangeira.

3 Maior destaque para os tratados ilustrados, como os de Palladio, Vignola e Serlio, que muitas vezes serviam como manuais ilustrados. Ramos (2011, p.59) afirma que, entre todos, o 'Regola delle cinque ordine', de Vignola, seria o "best-seller".
} 
América recém-descoberta, com os colonizadores europeus ${ }^{4}$. 0 tratado de Alberti foi traduzido para diversos idiomas ao longo do tempo, como se pode ver na Tabela 1:

\begin{tabular}{|c|c|c|c|}
\hline Local & data & idioma & Obs. \\
\hline Florença & 1485 & latim & Primeira edição impressa \\
\hline Paris & 1512 & latim & \\
\hline Estrasburgo & 1541 & latim & \\
\hline Veneza & 1546 & italiano & \\
\hline Florença & 1550 & florentino & $\begin{array}{l}\text { Edição de de Cosimo } \\
\text { Bartoli(reeditada seis vezes } \\
\text { entre XVI e XIX) - ilustrada }\end{array}$ \\
\hline Paris & 1553 & francês & \\
\hline Madrid & 1582 & espanhol & $\begin{array}{l}\text { corrigida e reeditada no } \\
\text { final do século XVIII }\end{array}$ \\
\hline Londres & 1726 & $\begin{array}{c}\text { italiana/inglesa } \\
\text { (bilíngue) }\end{array}$ & $\begin{array}{c}\text { A versão italiana publicada } \\
\text { é a de Cosimo Bartoli }\end{array}$ \\
\hline Viena & 1912 & alemão & \\
\hline Moscou & 1937 & russo & \\
\hline Praga & 1956 & tcheco & \\
\hline Varsóvia & 1960 & polonês & \\
\hline Milão & 1966 & italiano/latim & \\
\hline Lisboa & 2011 & português & \\
\hline
\end{tabular}

Tabela 1 - Compilação das versões do tratado de Alberti nos diversos idiomas em que foi publicado - pela primeira vez - até 2011. Fonte: Adaptado de $\mathrm{AMO}^{5}$.

Após Alberti, vários outros arquitetos trabalharam o tratado de Vitruvio, inclusive propondo edições ilustradas e tornando-o mais acessível. Um desses arquitetos, que estabeleceu uma relação diferente daquela albertiana com o texto de Vitruvio, foi Andrea Palladio. Enquanto Alberti inaugurou a tratadística arquitetônica renascentista, Palladio a encerrou.

Com caráter manualístico, ao lançar mão de seus próprios projetos como exemplos do que seria correto, Palladio sintetizou e sistematizou suas proposições, atingindo um público extremamente variado e, provavelmente, obtendo um alcance muito maior que o autor poderia sonhar.

Os dois tratados possuem diversos pontos de convergência e divergência que poderiam ser analisados, mas nessa pesquisa o enfoque se dá sobre as vilas, especialmente no modo como elas foram descritas por Alberti e Palladio em seus textos.

Trata-se de um programa recuperado da Roma Antiga e relacionado a muitas das mudanças que caracterizaram o

\footnotetext{
${ }^{4}$ Bueno (2011).

5 Amo (1988).
} 
Renascimento e o início da Idade Moderna. Assim como os tratados, as vilas também tiveram intensa produção no período, e também estiveram relacionadas com as profundas e diversas transformações que ocorriam na península itálica. Cada um à sua maneira, ambos os autores prestaram grandes contribuições ao desenvolvimento do tema.

Alberti participou da retomada dos textos antigos e formação da literatura renascentista sobre as vilas, no momento em que o sistema feudal entrava em declínio, com consequente expansão das cidades e mudança na forma de ocupação dos campos. Já a produção de Palladio aconteceu em um momento em que programa já estava mais maduro.

o objetivo desse trabalho é comparar os modelos de vila descritos por Alberti e Palladio, identificando os pontos de convergência e divergência entre eles. A opção por comparar as vilas que os dois autores apresentam em seus tratados, mesmo com a grande quantidade de vilas paladianas efetivamente construídas, deu-se pela intenção de se comparar os modelos de vilas que cada autor tinha como ideal.

É evidente que algumas das recomendações dos autores podem ser semelhantes por serem ambas originadas a partir do texto de Vitruvio, mas a discussão não visa estabelecer a genealogia do tema, e sim qual é o modelo de vila - ou modelos - para eles e quais suas semelhanças e diferenças.

De Alberti foi analisado seu tratado sobre a arquitetura, intitulado Da Arte de Construir, em que ele aborda diversos assuntos relacionados à arquitetura, de forma bastante detalhada. Para complementar a teorização acerca da vila albertiana, foram empregados o pequeno volume intitulado Villa e o I Libri della Famgilia. O autor apresenta várias diretrizes referentes à vida no campo e como deve ser a propriedade como um todo, desde sua localização até a organização e compartimentação interna dos espaços.

De Palladio foi analisado texto e os desenhos apresentados nos I Quattro Libri dell'Architettura. Ainda que, conforme já mencionado, muitos projetos de Palladio tenham sido construídos, a opção de não incluir esses edifícios no estudo exceto para elucidar eventuais dúvidas e ilustrar recomendações - é a grande variação que ocorre entre os projetos feitos inicialmente por Palladio, os edifícios efetivamente executados e aqueles publicados no tratado. 
Além disso, mesmo com contínuos esforços de datação e identificação da autoria das intervenções feitas nas vilas, ainda não se sabe com precisão quais variações em relação ao que foi publicado no tratado foram feitas na época de Palladio e, principalmente, sob sua supervisão, e quais foram feitas independentemente dele. Outro ponto importante é que, no tratado, ele incluiu a versão que, para ele, seria a ideal desses seus projetos, independendo de recursos para execução, aproveitamento de estruturas pré-existentes, ou quaisquer outros fatores externos.

Para desenvolvimento das comparações entre textos, desenhos e, eventualmente, edifícios, parte-se de duas premissas: a primeira é que o desenho e o texto são as grandes escrituras intelectuais da arquitetura, que tomaram a forma que têm ainda hoje no Renascimento; e a segunda, é que - como observa Howard Burns - o próprio Alberti faz a leitura de edifícios como se fossem textos.

A pesquisa foi iniciada consultando-se uma versão italiana do tratado de Alberti, organizada por Valeria Giontella e publicada em 2009. Em 2011, foi publicada a primeira tradução para a língua portuguesa - realizada em Portugal - a partir da edição latina, sob a criteriosa revisão disciplinar de Mário Júlio Teixeira Krüger. Professor Doutor da Universidade de Coimbra, Krüger é membro da Societè Internationale Leon Battista Alberti, que reúne os maiores estudiosos da obra de Alberti em todo o mundo e, por isso, essa passou a ser a edição de referência no desenvolvimento desse trabalho. Tanto a versão italiana, que estava sendo estudada anteriormente, quanto a versão publicada por Cosimo Bartoli, em 1565 - em florentino e com ilustrações (fac-símile) - foram utilizadas como apoio e consultadas para esclarecimento de eventuais dúvidas quanto à interpretação do texto.

A edição de referência do tratado de Palladio utilizada para desenvolvimento da pesquisa é - desde o início - a brasileira, publicada em 2009 e coordenada por Joubert José Lancha, professor Doutor do Instituto de Arquitetura e Urbanismo da Universidade de São Paulo, estudioso da obra de Palladio e orientador no desenvolvimento dessa tese. Essa edição, além da qualidade da tradução e das notas, possui ilustrações de melhor resolução que as demais, o que foi de grande importância para a compreensão das medidas inseridas por Palladio em seus desenhos e, consequentemente, para a 
reprodução esquemática dos projetos para realização do estudo. As edições de apoio são: a italiana original, de 1570, e uma edição espanhola de 1767, ambas disponíveis em fac-símile na internet.

Tendo em vista que Alberti também falou sobre as vilas em suas outras obras I Libri della Famiglia e Villa, elas também foram utilizadas nas comparações, de forma a esclarecer e ajudar na compreensão dos argumentos desenvolvidos no tratado. Sobre a obra de Palladio é feita a mesma concessão acerca de seus projetos Palladio desenvolvidos e não incluídos no tratado, como também de suas vilas efetivamente construídas.

Inicialmente é feita uma apresentação das mudanças e do contexto envolvido na produção dos tratados e das vilas, tendose em foco o modo como eles tenham sido influenciados. Depois são discutidas as vilas em um panorama mais amplo, que coloca Alberti e Palladio em dois extremos opostos do período.

Por fim, são feitas análises ponto a ponto acerca das obras de ambos os autores, identificando aproximações e divergências. Na pesquisa preliminar para desenvolvimento dessa tese já tinham sido identificadas algumas aproximações entre as proposições dos dois autores, mas esperava-se identificar mais divergências, tendo em vista as muitas diferenças que as fundamentavam. Mesmo estando em regiões diferentes, em épocas diferentes, escrevendo para um público completamente diferente e, por fim, planejando vilas para comitentes também diferentes, as aproximações entre as duas obras são surpreendentemente numerosas.

Foram utilizados diversos parâmetros para estabelecer a comparação entre as abordagens dos dois autores, o primeiro deles é a própria Organização dos tratados e sua relação com as vilas. Enquanto Alberti utiliza somente texto para compor um tratado em que os conteúdos se entrelaçam e se desenvolvem em vários livros e capítulos, formando uma espécie de teia, Palladio elabora um tratado conciso e linear, em que suas ilustrações são tão ou mais importantes que os textos.

O segundo parâmetro envolve a contraposição das Definições de Vila dos dois autores, onde se pode perceber claramente um reflexo do período e do local em que elas foram concebidas. Alberti participa do momento inicial, quando o tema é retomado na Toscana e precisa ser constituído apresentando, ao longo de aproximadamente dez anos, três diferentes 
definições que amadurecem conforme o tipo de uso que se tinha nas vilas desse período. Cerca de cem anos mais tarde, a vila de Palladio já tem definição mais madura e próxima do que se entendia por vila no Vêneto do século XVI.

Essa situação se repete também no terceiro parâmetro, onde são discutidas as orientações de ambos para a Escolha do Lugar onde implantar a vila.

O quarto parâmetro de comparação é o Processo de Projeto e a Representação Gráfica na Arquitetura, onde são percebidas algumas divergências e muitas aproximações entre os dois tratados. Em determinados trechos de seu tratado, Palladio parece estar ilustrando orientações albertianas, enquanto em outros ele desenvolve e aplica suas próprias regras.

No quinto parâmetro, onde é discutida a Hierarquia Social e adequação das vilas aos proprietários, percebe-se uma importante diferença entre os critérios apresentados por Palladio. No texto seus critérios se afastam daqueles albertianos, já nos desenhos eles são muito semelhantes ao que prescreve Alberti.

o sexto parâmetro de discussão é a relação entre a Compartimentação e a setorização para cada um dos autores. Também aqui são percebidas inúmeras aproximações entre as propostas, com trechos de texto que parecem complementares, tamanha semelhança, sobretudo no que se refere à organização da vila como um todo. Apesar disso, aqui também é identificada uma diferença significativa, quanto à organização do interior da casa de vila: enquanto Alberti propõe uma setorização tripartida que parece antecipar a tripartição residencial burguesa, Palladio opta por - cerca de cem anos mais tarde defender um modelo bipartido, próximo do que se utilizava à época, mas com algumas inovações no tratamento e na divisão dos fluxos.

Por fim, no sétimo e último parâmetro é feita uma discussão acerca da Compartimentação e Dimensionamento das casas de vila. São identificadas tanto divergências quanto aproximações, na conceituação e também nas orientações específicas para o projeto. Um ponto bastante significativo é a utilização das proporções musicais para estabelecer as relações entre cada uma das partes do edifício e entre as partes com o todo. Ainda que Palladio, em seu texto, não faça referência a 
todas as proporções sugeridas por Alberti, percebe-se que nos projetos ele lança mão de várias delas.

Ao longo dessa análise, percebe-se que o modelo de vila concebido por Palladio tem vários pontos em comum com aquele descrito por Alberti. Ainda que os dois autores tenham atuado em épocas e locais diversos, seus modelos de vila apresentam quase tantas semelhanças quanto diferenças.

Em seu tratado, Palladio cita Alberti, indicando que leu De re Aedificatoria e, ao longo dessa pesquisa, percebe-se que ele não só o leu como teve como uma de suas bases ao compor I Quattro Libri.

Além das semelhanças entre os dois tratados, onde a relação entre os dois é mais óbvia, Palladio parece dialogar com Alberti também nos momentos em que interrompe essas semelhanças com rupturas bruscas e mudanças de foco em relação aos preceitos de seu antecessor.

Ainda há muitos aspectos das duas obras que poderiam ser investigadas e comparadas, mas nessa primeira análise, os resultados obtidos superaram em muito o que se esperava no início. 



\section{Produção arquitetônica na Itália renascentista}

Grande parte da dificuldade para se situar temporalmente - Renascimento advém das diferentes formas com que ele se manifestou nos países do continente europeu, e do seu alargado arco temporal. Nesse trabalho, o enfoque principal está nas manifestações que caracterizaram o Renascimento na Itália, pois os dois arquitetos, cujas vilas são aqui discutidas, foram produtos desse contexto. Embora existam muitas divergências a respeito dos limites cronológicos do Renascimento, seu início está associado às grandes transformações que, tendo início ainda no século XI, marcaram a passagem da Idade Média para a Idade Moderna.

A realização das Cruzadas propiciou a retomada do comércio no mar Mediterrâneo, favorecendo a implantação de um eixo comercial entre Ocidente e Oriente e, com isso, o surgimento da burguesia mercante. Além do que, também marcaram esse momento as grandes navegações, que em 1492 culminaram com a descoberta da América; a invenção da impressora com tipos móveis, por Johannes Gutenberg (1445); a perda de poder da Igreja Católica e as reformas religiosas; e ainda a formação dos estados nacionais europeus.

Durante a maior parte da Idade Média, os mosteiros foram os centros de cultura europeus, nos quais os monges preservavam manuscritos e obras da Antiguidade Clássica, enquanto o restante da sociedade era formado por analfabetos. As primeiras Universidades, criadas a partir do século XII, também estavam vinculadas à Igreja, o que fez com que mesmo no início do Renascimento elas mantivessem forte ligação com a filosofia e as tradições medievais. As "igrejas e monastérios converteramse no centro espacial, político e econômico europeu, ao incorporarem as verdades divinas que deveriam reger o mundo humano" ${ }^{1}$.

Nesse período, a importância da arquitetura para a Igreja era muito grande visto que, por meio dessas obras, o espírito do leigo era impressionado e colocado em contato com a escolástica ${ }^{2}$. A catedral medieval era pensada para levar os fiéis ao altar, que era o ponto culminante da organização

\footnotetext{
1 Cf. Brandão (1999, 39).

2 Nesse ponto, Brandão (1999, p.49) sugere a leitura de Architecture gothique et penseé scolastique, de Erwin Panofsky, 1976.
} 
espacial ${ }^{3}$. O peso formal das catedrais românicas e depois a verticalidade das catedrais góticas, com suas estruturas aparentes, visavam provocar nos fiéis uma sensação de pequenez frente à Igreja e ao poder divino.

A produção arquitetônica nesse período estava quase sempre vinculada à Igreja e o modo como eram produzidas as grandes catedrais concentrava os profissionais da construção de várias gerações nesses canteiros, o que também limitava o espaço à formação da consciência e expressão individual.

o homem era visto como membro de uma família, povo, partido, corporação, raça ou alguma outra coletividade. Esse modelo fixava o universo compositivo de cada classe no cumprimento de uma rígida disciplina comportamental, fazendo com que qualquer manifestação da criatividade individual fosse bloqueada, ignorada ou relegada ao esquecimento ${ }^{4}$.

A loja dos construtores, que se formou nos séculos XII e XIII, era uma espécie de cooperativa de artistas e artesãos encarregados da construção de grandes igrejas ou catedrais. Quando uma comunidade ou instituição encomendava um edifício, nomeava ou aprovava um magister lapidum, responsável pelo planejamento artístico, a distribuição de tarefas e a coordenação do trabalho dos indivíduos, e também um magister operis, encarregado do fornecimento de materiais e mão-de-obra. Assim, a esses dois mestres - ou, em alguns casos, um mestre que desempenhava os dois papéis - cabia a tarefa de executar as obras sob regras pré-definidas pelas suas corporações ${ }^{5}$. Não havia um momento de criação ou de projeto distinto daquele da fase de realização da obra, o projeto e a construção aconteciam simultaneamente.

Na coletividade das lojas, o 'saber fazer' era objeto de sigilo por parte de seus membros. No caso dos artesãos das lojas que trabalhavam na construção de edifícios, esse conhecimento - 'saber fazer' - englobava também os processos que permitiam traçar a elevação a partir da planta e outros procedimentos sigilosos no exercício da profissão do arquiteto ${ }^{6}$.

\footnotetext{
3 Cf. Malard (2006, p.65).

4 Cf. Tavares $(2003, \mathrm{p} .17)$.

5 Cf. Hauser $(2000$, p.248).

6 Cf. Oliveira (2002). Esse é um dos motivos apresentados pelo autor para a falta de desenhos no período medieval mais antigo, os demais são: poucos desenhos em pergaminho, devido a seu alto custo; desenhos restritos a 28
} 
A nobreza feudal, cujo poder se baseava na propriedade de terras e na economia agrícola, não tinha interesse na expansão e desenvolvimento das cidades, mas no decorrer dos séculos XII e XIII, com o enfraquecimento do sistema feudal, esse cenário mudou. Com a migração dos camponeses para as cidades, buscando refúgio contra as lutas entre príncipes e os ataques de salteadores ${ }^{7}$, o comércio nesses centros se desenvolveu e passou a atrair sempre mais pessoas que deixavam as terras senhoriais.

Entre o fim do século XIII e o início do século XIV, com a grande expansão econômica e política de Florença, a arquitetura teve um forte impulso, quando surgiram Santa Maria del Fiore, Santa Croce, Santa Trinità e Santa Maria Novella. Passava-se do gótico, ao gótico tardio, onde se deixava de buscar o prestígio arquitetônico das grandes obras e preferindo edifícios menores e muito ornamentados ${ }^{8}$.

O pagamento dos trabalhadores da construção mudou radicalmente a organização do trabalho que vigorava até o momento, pois tornava possível a migração da mão de obra de uma construção para outra, em função do orçamento destinado a sua execução. Ainda que no início do uso da mão-de-obra livre a migração tenha ocorrido em escala reduzida, com o passar do tempo começou a se intensificar, causando variações na quantidade de trabalhadores em uma obra durante as diferentes etapas de sua execução.

A possibilidade de deslocamento da mão de obra fez com que as construções góticas, diferentemente das sempre morosas construções românicas, tivessem a velocidade de sua construção vinculada à disponibilidade de dinheiro. De acordo com os recursos do patrocinador, a obra poderia avançar rapidamente com os mesmos trabalhadores empregados ou poucas mudanças, ou poderia ter interrupções e mudanças de ritmo, sendo empregadas maiores ou quantidades de artistas e artesãos em diferentes momentos ${ }^{9}$.

Nesse momento, as lojas tinham uma capacidade de deslocamento notável, mas, a despeito de toda e qualquer

monumentos de grande porte; marcação das plantas em verdadeira grandeza no próprio terreno; utilização dos pisos preparados para riscos que os ingleses denominavam tracing floor e das pranchetas (ostrichboard); reutilização dos pergaminhos para escrita, outros desenhos ou encadernação.

Cf. Koch (1994, p.31).

${ }^{8}$ Cf. Argan, (1999, p.49).

9 Cf. Hauser (2000, p.250). 
mobilidade, elas ainda estavam vinculadas aos meios de execução, não tendo, portanto, autonomia referente à concepção dos trabalhos que desenvolviam.

Durante o século XIV, além do comércio e do artesanato, outras atividades prosperaram e impulsionaram um crescimento ainda maior das cidades, aumentando a mão de obra disponível e possibilitando também a formação de um mercado consumidor.

Formava-se a burguesia, uma nova classe social constituída pelos comerciantes enriquecidos e que almejavam um papel tão importante no cenário político como o que tinham no econômico. Seus interesses iam muito além do valor do dinheiro, passando por artes, História, habilidades de escrita, aprendizado de línguas, entre outros, culminando na busca de prestígio. "A nova camada burguesa, pretendendo impor-se socialmente, precisava combater a cultura medieval, no interior da qual ela aparecia como uma porção inferior e sem importância da população. "10.

A interferência da burguesia no mercado de arte passou a ocorrer tanto pelo consumo por parte dos próprios comerciantes, quanto por uma nova mercadoria a ser negociada ${ }^{11}$, formando um cenário propício para que artistas e artesãos buscassem independência profissional. Para pintores e escultores isso se tornou possível já no decorrer do século XIV, mas para os artesãos que trabalhavam na construção, somente dois séculos mais tarde as encomendas de cidadãos particulares atingiram um volume suficiente para que eles pudessem atuar por conta própria ${ }^{12}$.

Chegando às cidades esses trabalhadores estavam livres das muitas regras que tinham nas lojas, mas para atuar como mestres independentes deveriam aderir a corporações citadinas chamadas guildas, que pretendiam ser associações de empresários em igualdade de condições e que, apesar de seu caráter protecionista, criaram um cenário favorável ao desenvolvimento da expressão individual, pois, permitiam que os mestres que as

10 Cf. Sevcenko (1988, p.24).

11 Warnke (2001, p.127) descreve esse cenário e sinaliza que Vasari já fazia essa afirmação em seu Le vite dei più eccellenti architetti, pittori et scultori italiani, da Cimabue ai tempi nostri.

12 Também nessa época aconteceu a proliferação das vilas em toda a Itália, o que tornou esse programa, livre das limitações dos terrenos citadinos, um campo fértil para o desenvolvimento das características individuais dos arquitetos. 
integravam dispusessem de seu próprio tempo e escolhessem seus meios artísticos ${ }^{13}$.

Ainda não existia, entretanto, a valorização das características individuais das obras de arte e a personalidade do artista ainda não era reconhecida como tal, mas surgiam as bases para que isso acontecesse.

Se na época medieval os pormenores da obra eram estabelecidos durante sua execução pelos mestres de obras e seus auxiliares, dali por diante, por meio da representação gráfica, o projeto podia conter uma grande parte dos detalhes necessários para sua execução. Nesse panorama, a técnica era apenas "o prolongamento da invenção na realidade física e só neste sentido interessa ao arquiteto deixando a outros as preocupações de ordem prática e procurando apenas fazer com que tais exigências não interfiram com o resultado final." ${ }^{14}$. o executor era encarregado apenas da realização manual do projeto, enquanto surgia a figura do arquiteto detentor do conhecimento científico e da teoria - demonstrando, dessa maneira, o caráter intelectual do processo compositivo.

\begin{abstract}
"Ela <a perspectiva> possibilita ao arquiteto, então, deter-se na ideia contida no projeto mais do que na própria construção; surge como a verdadeira essência da obra de arte. O artista deixa de ser artesão e torna-se intelectual, e a arquitetura perde o caráter orgânico determinado pela matéria para tornar-se mais abstrata, mais desenhada, revelando a lógica matemática pela qual o homem projetou o espaço." 15
\end{abstract}

A criação artística, vista como atividade intelectual, passava a gozar de maior prestígio que a execução, considerada uma atividade meramente manual. Pintores, escultores e arquitetos reivindicaram o reconhecimento da autonomia da intelectualidade em seu processo produtivo, de forma que ele não fosse visto apenas como trabalho braçal, repetitivo e, sobretudo, coletivo.

Foi travada uma espécie de disputa para estabelecer qual seria a maior das artes, com os artistas defendendo a superioridade de sua prática profissional em relação às demais

13 Cf. Hauser (2000, p.253-255).

14 Benevolo discorre sobre o tema em Introdução à Arquitetura (1972, p.144 a 147).

${ }^{15}$ Cf. Brandão (1999, p.86). 
e reivindicando a inclusão dela no rol das sete artes liberais: - trivium - Gramática, Retórica e Dialética - e o quadrivium Aritmética, Geometria, Música e Astronomia.

"Chamava-se 'livre' (liberalis), a 'arte' (ars)
que fosse digna de um homem livre, portanto, a
que não fosse exercida por meio do trabalho
físico nem em vista de uma remuneraço; a que
fosse exercida por prazer desinteressado. (...)
Quem, em resultado de sua atividade intelectual,
é responsável pela criaça da 'obra', o opus, na
mente, pode deixar sua realizaça para os
artesãos, que dominam as técnicas da scientia.
Essa atividade secundária pode ser calculada,
avaliada e paga. A verdadeira produção da virtude
é incomensurável e pode apenas ser 'patrocinada'
e 'estimulada'."

Apesar disso, "foi somente no decorrer do século XV que, seguindo à emancipação do artista sustentada por uma teoria artística classicista e idealizante, «arte alta» e «arte popular» foram separadas."17. Nas cortes italianas os artistas se aproximaram desse status ideal, pois lá

"desenvolveram-se liberdades para os artistas que, sem a retaguarda da corte, jamais lhes seriam concedidas nas cidades. (...) o serviço aos príncipes era basicamente uma atividade 'livre', não um serviço remunerado, mas um serviço de virtude, baseado no juramento de lealdade recíproca." ${ }^{18}$

A admissão de artistas, especialmente pintores, nessas cortes era motivo de constantes protestos por parte das corporações. Existirem profissionais desempenhando suas funções sem estarem vinculados a alguma guilda e tampouco sem terem as qualificações necessárias - segundo as próprias guildas - para - exercício das atividades era algo bastante negativo para a manutenção dessas instituições. Além disso, os artistas de corte gozavam de um prestígio muito maior que os mestres que atuavam nas cidades ${ }^{19}$.

"Diferente do que estamos acostumados a pensar hoje, o valor do conhecimento e das virtudes dependia então de sua representação para um público, e de seu reconhecimento e apreciação por um público. Estamos diante de um tipo de sociedade

\footnotetext{
16 Cf. Warnke (2001, p.65).

Cf. Wittkower (1992, p.197).

18 Cf. Warnke (2001, p.60-65).

19 Idem, p. 70 .
} 
em que a visão se impunha como o órgão regulador do comportamento por excelência e em que a admiração do outro era a recompensa do comportamento bem-sucedido. Essa era a sociedade de corte. "20

Nesse período, o surgimento do ideal de gênio com talento inato veio de encontro a todas as regras corporativistas que imperavam na atuação dos artistas vinculados às lojas e guildas, uma vez que o desenvolvimento dessa espécie de dom não dependeria de algum vínculo com as instituições de origem medieval. Passou a ser possível acreditar em afirmações como a seguinte:

"Um iniciante poderá, graças a 'seu amor pela
arte', desenvolver-se também 'sem qualquer
orientação de um mestre'; mas em geral o que
acontece é que um jovem, justamente em
consequência desse amor espontâneo pela pintura,
tem necessidade de um aprendizado".

Os iniciantes nesse período tinham formação cultural bastante variada, visando sua aproximação do ideal renascentista de Homem Universal. Esse cenário favorecia uma situação bastante comum: quando um grande artista sobressaía em determinado campo, era frequentemente chamado a atuar em outra área, não porque entendesse do ofício, mas apenas porque era um grande artista ${ }^{22}$.

Dois fatores foram fundamentais para a reivindicação da arquitetura como arte liberal e serão apresentados a seguir: a produção de tratados, que formou a base teórica para essa mudança, exaltando o processo de trabalho artístico e destacando sua concepção intelectual; e o desenvolvimento do desenho, que reivindicava ser, além de uma ferramenta de trabalho, uma espécie de documentação desse processo mental.

\section{O desenho de arquitetura}

o uso do desenho em si não era uma novidade, pois foi durante o período medieval, mais precisamente no século XII,

20 Cf. Paiva (2009, p.92).

21 Cennino Cennini, em Il Libro dell'Arte, nos capítulos.2 e 3 afirma que, mesmo tendo talento natural, o próprio iniciante, por amor à arte, irá buscar um bom mestre com quem aprender (apud Warnke, 2001, p.71).

${ }^{22}$ Cf. Malard (2006, p.60). 
que a geometria de Euclides foi traduzida, mas permaneceu como segredo profissional até meados do século XV. ${ }^{23}$

"Um dos detalhes da formação do arquiteto
medieval deveria ser o desenvolvimento da
sua habilidade na técnica de representação
gráfica, ao lado do ensinamento dos
procedimentos geométricos geradores dos
traçados. A alta qualidade gráfica de alguns
conhecidos exemplares assim o atesta. (...)
Além da evidêcia apoiada pelos inúmeros
exemplares encontrados, existem outras
tantas referências literárias que nos falam
sobre o desenho medieval e a sua importância
para prafissional do
arquiteto." ${ }^{24}$

Frequentemente era necessário recorrer à ortogonalidade para se representar com precisão os elementos estruturais esbeltos no projeto das catedrais góticas do norte da Europa (Figura 1).

'Através do exame dos desenhos medievais,
verifica-se que inicialmente o desenho
esteve atrelado à função operacional e, aos
poucos, foi ganhando amplitude de trabalho
nas operaçoses Os chamados álbuns de
desenhos revelam que, como por exemplo
aquele de Villard de Honnercourt, as
representações poderiam atender a
finalidades diversas, mas, de modo geral,
anunciavam a emancipação do arquiteto
enquanto caminhavam "da condição de mero
serviçal" nos trabalhos e na execução da
obra "à posição de elemento enunciador do
executável"."25

23 Oliveira (2002) defende a utilização da geometria euclidiana e do sigilo em torno dos métodos e argumenta com a citação do Artigo 13 da convenção de Regensburg, feita por Paul Frankl, em the secret of the mediaeval masons. Art Bulletin, New York, v.28, n.1, p.47-60, Mar: 1945. p.46, "Também nenhum operário, quer mestre, quer encarregado, quer companheiro, ensinará a quem quer que seja, qualquer que seja o seu título, não sendo do nosso ofício ou nunca tendo feito trabalho de pedreiro, como conseguir a elevação partindo do plano."

${ }^{24}$ Cf. Oliveira (2002, p.133).

${ }^{25}$ Cf. Souza (2006, p.62). 


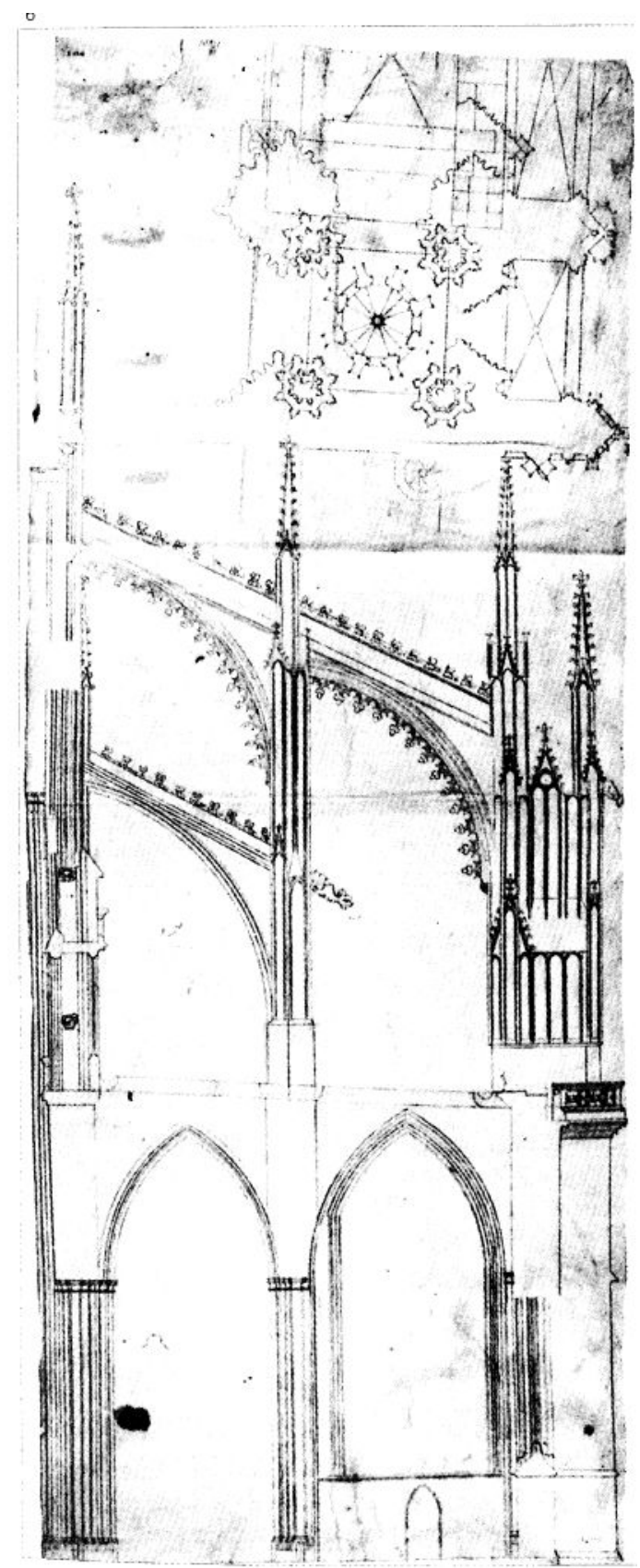

Figura 1 - Ateliê de Peter Parler, corte da Catedral de Praga, cerca de 1430. Fonte: Ackerman, 2003, p.39. 
Até então, por desenho de arquitetura se entendia toda a forma de grafismo destinado a representar o edifício ou parte dele, com a finalidade de comunicar a idéia de um projeto, ou cadastrar uma construção, por motivos didáticos ou pró-memória. Muitas vezes se desenhava em notas de trabalho ou mesmo em esquemas distributivos pouco desenvolvidos.

Sua importância decorria de ser um componente do processo construtivo do edifício, que englobava principalmente o conhecimento técnico da execução das obras, já que a cultura arquitetônica se baseava essencialmente na prática de canteiro e se ocupava da resolução de problemas construtivos:

"O Gótico estava solidamente ancorado na
prática construtiva do seu tempo, as
oficinas de pedreiros ou os locais de
construça faziam também as vezes de locais
de aprendizagem, onde os saberes e os saber-
fazer (..) se transmitiam oralmente de
geração em geração."

A novidade, nesse momento, passa a ser na verdade a utilização do desenho para conceber o edifício, e não somente para representá-lo. Para os arquitetos renascentistas, esse uso do desenho no processo de concepção do projeto era essencial para conferir à arquitetura status de arte intelectual e, também, para reaproximá-la de conceitos como proporção, equilíbrio, simetria, harmonia e outros, que na Idade Média haviam perdido importância.

"A geometria é também o fundamento estético
do Renascimento. Alberti ensina que a beleza
reside em duas qualidades: a geometria e o
ornamento. A geometria assegura as
proporços e as dimensões que irão fazer
belas formas. o ornamento é acrescentado à
geometria como um adicional de beleza. Esse
conceito é muito próximo do entendimento
platônico de que ordem e beleza são
sinônimos." 27

$\mathrm{Na}$ Itália e nos demais países do sul da Europa, no período medieval a representação gráfica de edifícios também empregava a ortogonalidade mas com certa aproximação às

${ }^{26}$ Cf. Thoenes (2003, p.10).
27 Cf. Malard (2006, p.65). 
técnicas de pintura perceptível pelo uso de efeitos de luz e sombra, para simular diferentes profundidades (Figura 2).

O primeiro arquiteto renascentista a se manifestar contra a utilização das técnicas de pintura na representação arquitetônica, por considerá-las inadequadas às exigências da construção, foi Leon Battista Alberti. Ele destacava a importância do que hoje se conhece como projeção ortogonal e das perspectivas geométricas, como sendo a única forma de se garantir a precisão do desenho de um edifício existente ou futuro $^{28}$. O ponto de vista expresso por Baldassare Castiglione e Rafael Sanzio em sua Lettera a Leone $X$ aproximou-se muito do que preconizava Alberti:

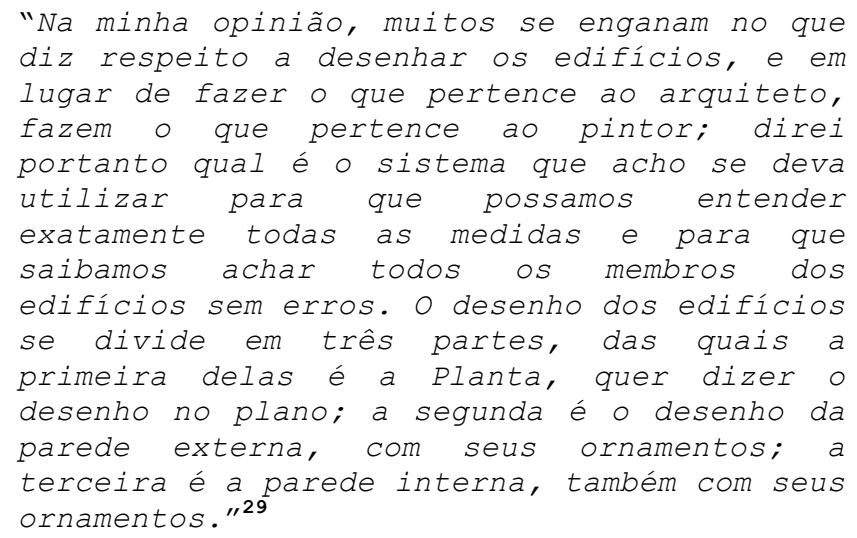

Os edifícios do Renascimento deveriam exaltar a beleza das geometrias puras, com cada elemento inserido em um desenho harmônico e bem proporcionado. Formas regulares se repetiam nas plantas da época: o quadrado, a cruz grega e, sobretudo, a circunferência - que simbolizava a harmonia e o equilíbrio perfeitos. Segundo Alberti, apenas a circunferência poderia exprimir a essência perfeita de Deus e de sua criação; além disso, os estudos das proporções demonstraram que o corpo humano cabia exatamente na circunferência.

28 Cf. Ackerman (2003, p.49).

${ }^{29}$ Cf. Souza, (2006, p.137). 


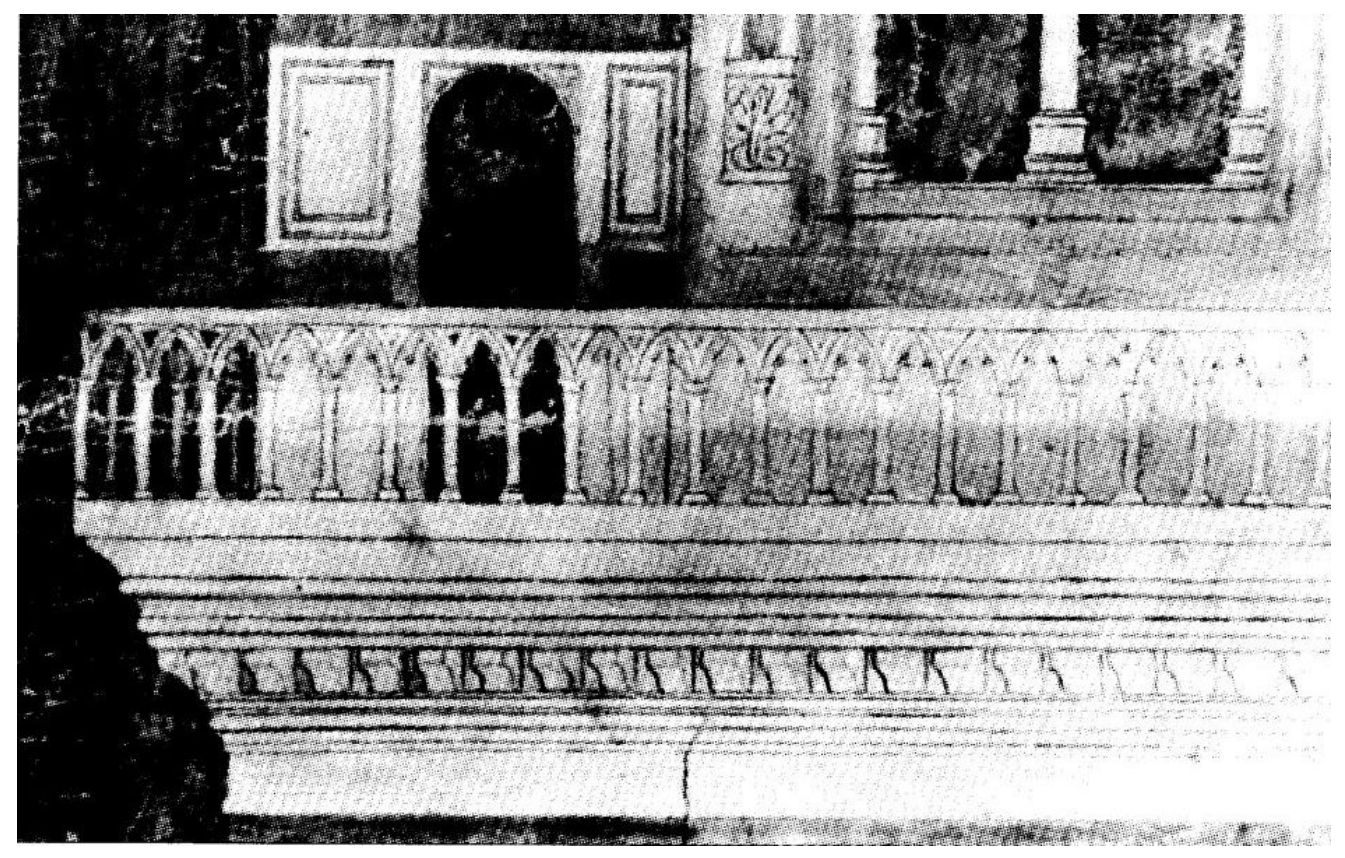

Figura 2 - Detalhe do projeto para o Campanário da Catedral de Florença, primeiro quarto do século XV. Fonte: Ackerman (2003, p.43). 
Interessados em variadas áreas do conhecimento e imbuídos das ideias estéticas e filosóficas em voga, os artistas e humanistas da Renascença também se dedicaram ao estudo das proporções do corpo humano - cânone da composição formal desenvolvida na Grécia Antiga. Diversos arquitetos e artistas desse período desenvolveram estudos de proporções antropométricas, retomando aquelas enunciadas por Vitruvio em seu tratado, escrito no século I a.C, intitulado De Architectura Libri Decem ${ }^{30}$ :

"O umbigo é, naturalmente, o centro do
corpo; com efeito, se um homem se puser
deitado de costas com as mãos e os pés
estendidos e colocarmos um centro de
compasso no seu umbigo, descrevendo uma
circunferência, serão tocados pela linha
curva os dedos de qualquer uma das masos ou
dos pés."

O estudo que se tornou mais conhecido foi um desenvolvido por Leonardo Da Vinci (Figura 3). A ideia do homem definido como o centro foi transportada para um sistema de apreensão e representação espacial: a construção do espaço baseada em uma perspectiva com ponto de fuga central. Para desenvolvê-la, Filippo Brunelleschi utilizou a geometria euclidiana.

"Baseado no teorema de Euclides, que
estabelece uma relação matemática
proporcional entre objeto e e sua
representação pictórica, Brunelleschi
instituiu a técnica do 'olho fixo', que
observa o espaço como que através de um
instrumento ótico e define as proporções dos
objetos e do espaço entre eles em relação a
esse único foco visual. (...) Esse método
obteve de imediato uma tal aceitação dos
pintores, por sua qualidade de lhes
propiciar um total controle do espaço
representado, que foi denominado 'construção
legitima'."

${ }^{30}$ Cf. Pollio (2007, p.168). Vitruvio, ao falar sobre a construção de templos, argumenta que seu projeto deveria ser bem proporcionado assim como, com justas proporções, a natureza concebeu o corpo humano.

31 Cf. Sevcenko (1988, p.30). 


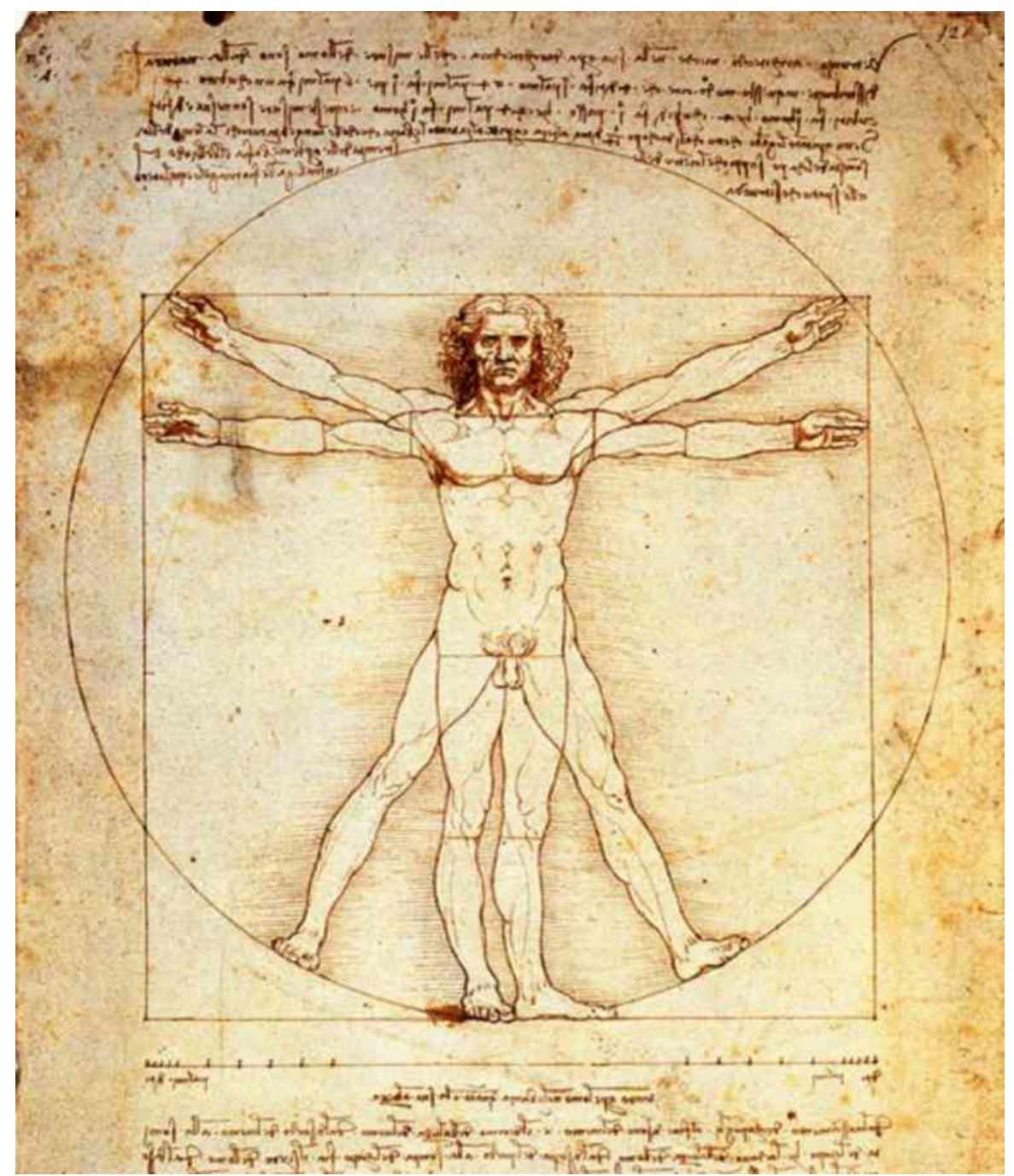

Figura 3 - Leonardo da Vinci. O Homem Vitruviano. A proporção das partes é igual ao número de ouro (Ф). Fonte: Andrade (2008, p.5). 
Com a aplicação correta da geometria, construída sobre leis racionais, acreditava-se que seria possível assegurar um bom resultado estético. Não era somente "uma reflexão intelectual sobre o dado percebido pelos olhos, mas o modo de ver segundo o intelecto, primeiro com a mente, depois com os olhos. "132

A influência do Humanismo e do intelectualismo do século XV na arquitetura também se manifestou em termos espaciais, resumidos em leis e relações mais facilmente compreensíveis:

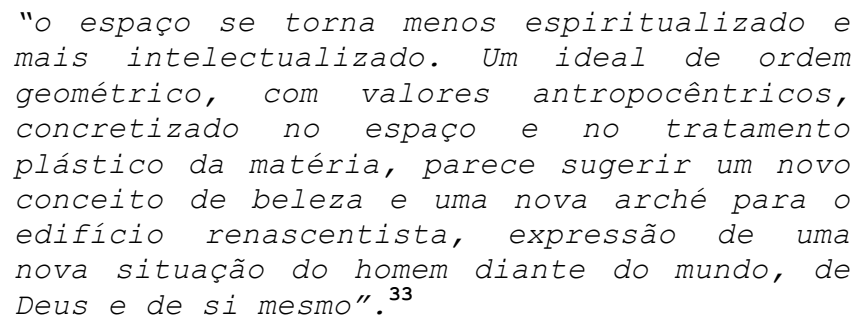

Ao invés de o espaço oprimir e possuir o homem, ele é que era capaz de apreender as leis simples que governavam o espaço e, em poucos momentos, obter o segredo do edifício ${ }^{34}$. A beleza, para os arquitetos renascentistas, estava vinculada à racionalidade compositiva e provinha de "uma razão matemática, inspirada na nova maneira burguesa de ver o universo, que substitui a racionalidade metafísico-religiosa da escolástica característica do século XIII"135.

Nesta busca de justa proporção e harmonia, o Renascimento retomou a linguagem clássica da arquitetura que havia desaparecido progressivamente durante a Idade Média.

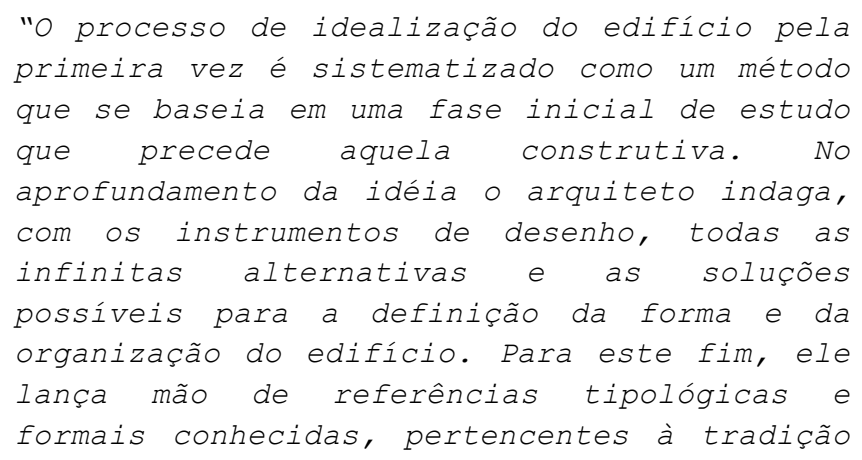

32 Cf. Argan (2003, p.132).

33 Cf. Brandão (1999, p.66-67).

34 Cf. Zevi (op cit).

35 Cf. Brandão (1999, p.70). 
da arquitetura clássica, e se vale de um corpo de regras proporcionais e dimensionais estabelecidas antecipadamente, que o ajudam a harmonizar e combinar estes elementos. "36

\title{
o retorno a Vitruvio
}

O discurso teórico dos arquitetos renascentistas, além de se basear no estudo dos edifícios construídos no período clássico, também empregou referências escritas, na busca de prerrogativas teóricas dessa arquitetura que pudessem ser úteis no novo contexto.

\begin{abstract}
"oferecia-se uma nova via ao arquitecto: a produção 'literária'. Não que ela fosse (apenas) o meio de melhorar a sua posição na corte, mas o manuseamento da palavra tocava no coração e no princípio do seu trabalho. Ao escrever, ele procurava verificar aquilo que realizava enquanto construtor. Foi portanto o nível da reflexão e do aprofundamento filológico que se efetuaram a elaboração do estilo e a constituição de um novo cânone formal 'all'antica'." ${ }^{37}$
\end{abstract}

o único tratado remanescente desse período é o De Architectura Libri Decem, de Vitruvio, que durante a Idade Média já tinha sido copiado, analisado e ilustrado, mas que era conhecido somente no universo monástico. No início do Quattrocento, o humanista Poggio Bracciolini ${ }^{38}$ foi um dos primeiros humanistas do mundo moderno a estudá-lo e, a partir daí

"o texto vitruviano tornou-se interlocutor
obrigatório da tratadística arquitetônica,
bem como de arquitetos, pintores, escultores
e, igualmente, músicos. Como único tratado
da Antiguidade em seu gênero que sobreviveu,
sendo, portanto, elevado à natural condição

36 Cf. Furnari (1993, p.175) tradução da autora, do italiano: Il processo di ideazione dell'edificio per la prima volta viene sistematizzato come un metodo che si basa su di una fase iniziale di studio che precede quella costruttiva. Nell'approfondimento dell'idea l'architetto indaga, con gli strumenti del disegno, tutte le infinite alternative e le soluzioni possibili per la definizione della forma e dellorganizzazione dell'edificio. A tal fine egli attinge a riferimenti tipologici e formali conosciuti, che appartengono tutti alla tradizione dell'architettura classica, e si avvale di un corpo di regole proporzionali e dimensionali stabilite a priori, che lo aiutano ad armonizzare e a mettere insieme questi elementi.

37 Cf. Thoenes (2003, p.23).

38 Vários autores citam a redescoberta do tratado de Vitruvio no Renascimento, mas Murray (2007, p.XIII) atribui essa redescoberta especificamente a Poggio Bracciolini. 


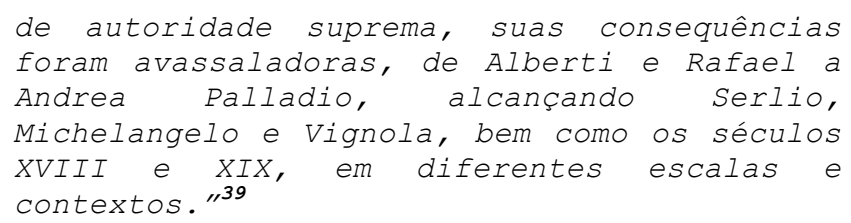

A divulgação desse texto fortaleceu ainda mais a relação entre a arquitetura do Renascimento e a arquitetura Clássica: "com a reapropriação do texto de Vitruvio pelos humanistas, quando Leon Battista Alberti, reconhecendo nos Dez Livros um modelo exemplar, Ihe confere o estatuto de norma arquitectónica, as ordens de colunas clássicas tornam-se um cânone obrigatório" ${ }^{40}$.

Ainda que tenha sofrido duras críticas em relação à linguagem e também ao conteúdo, o tratado de Vitruvio favoreceu - florescimento das reflexões teóricas acerca do fazer arquitetônico,

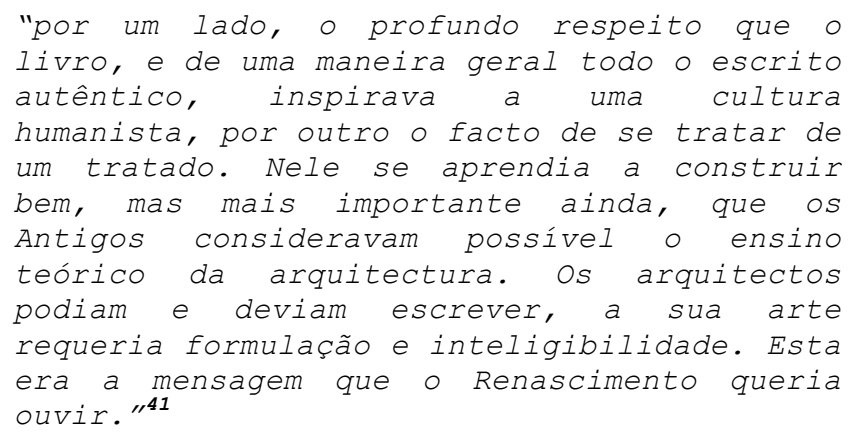

Vários arquitetos do período estudaram o tratado de Vitruvio, inclusive propondo novas edições ilustradas que contribuíram não somente para torná-lo mais acessível, como também para transformar a Teoria da Arquitetura em um gênero próprio dentro da Teoria da Arte ${ }^{42}$. A grande novidade nesse momento era "passar dos estudos dos textos ao dos actos construídos, compreender as fórmulas vitruvianas, combiná-las com o conhecimento dos vestígios antigos, representar a arquitectura greco-latina e finalmente transpor o todo para a prática." "43

${ }^{39}$ Cf. Brolezzi (2007, p.25-26).

40 Cf. Evers (2003, p.6).

41 Cf. Thoenes $(2003$, p.9).

42 Cf. Evers (2003, p.6).

${ }^{43}$ Cf. Thoenes (2003, p.10). 
Os arquitetos do Renascimento buscaram, com a elaboração de tratados sobre a arquitetura, uma sistematização dos conceitos. De Alberti a Scamozii ${ }^{44}$, eles se empenharam em estabelecer as bases conceituais da construção da arquitetura do Renascimento. A pesquisa pictórica e a teorização filosófica criaram, contemporaneamente, os pressupostos para uma profunda mudança das concepções espaciais do ambiente físico e, consequentemente, da arquitetura ${ }^{45}$.

"Os tratados de arquitetura são livros, e é
através deles que o arquitecto se torna uma
pessoa pública. Na Idade Média, a teoria
arquitectónica era ainda cifrada,
'misteriosa', elaborada de cima para baixo,
por escalóes sucessivos, e transmitida no
seio das lojas de pedreiros. Com o tratado,
ela emerge do seu mundo fechado e espalha-
se, atingindo uma clientela que vem de todos
os horizontes e que conta tanto com
especialistas como com amadores."46

A parte II do Livro I do tratado de Vitruvio teve grande influência sobre os tratadistas do Renascimento, pois lá ele defendia que existe uma diferença entre arquitetura e construção. Esta distinção se apoiava, além de na emoção, na categoria da beleza manifestada através de uma harmonia universal que pode ser encontrada na natureza e, consequentemente, no homem. Conceito exaustivamente repetido e explorado nos tratados sobre a arquitetura desenvolvidos no Renascimento. Entre todos os conhecimentos que um arquiteto deve ter para exercício de seu trabalho, Vitruvio destacava a representação arquitetônica afirmando que o arquiteto

"deverá ser instruido na ciência do desenho,
a fim de que disponha da capacidade de mais
facilmente representar a forma que deseja
para as suas obras, através de modelos
pintados. A geometria, por sua vez,
proporciona à arquitetura muitos recursos.
(...) através da aritmética, se calculam as
despesas dos edificios, se define a lógica
das medidas e se encontram soluços para as
dificeis questóes das comensurabilidades

44 Ainda que muitas vezes os tratados de Palladio e, sobretudo, Scamozzi sejam considerados maneiristas, aqui foi adotada a classificação proposta por Evers (2003).

${ }_{45}^{45}$ Cf. Furnari (1993, p.175).

${ }^{46} \mathrm{Cf}$. Thoenes (2003, p.14). 
através da lógica e de métodos
geométricos." ${ }^{\mathbf{4 7}}$

\section{A Arquitetura no Renascimento}

Filippo Brunelleschi, que para muitos estudiosos assinala - início do Renascimento na arquitetura, foi o responsável por organizar as primeiras escavações à procura de vestígios de edifícios antigos, em Roma, no ano de $1400^{48}$. Bruno Zevi ${ }^{49}$ destaca que, a partir de Brunelleschi, o novo elemento que aparece na arquitetura do século XV não vem integralmente da arquitetura clássica, mas é "essencialmente uma reflexão matemática desenvolvida sobre a métrica românica e gótica. Busca-se uma ordem, uma lei, uma disciplina contra a incomensurabilidade, a infinitude e a dispersão do espaço gótico, e a casualidade do românico". Segundo Argan ${ }^{50}$, Filippo Brunelleschi foi o responsável por estabelecer a diferença entre o arquiteto e o mestre de obras "o que é uma revolução em relação à hierarquia unitária da Idade Média". Já para Benevolo ${ }^{51}$, a grande importância de Brunelleschi para a arquitetura do Renascimento foi estabelecer, na primeira metade do século XV, uma relação entre suas duas principais características, que tinham trajetórias precedentes independentes uma da outra: a discussão sobre o papel social do arquiteto e a formação de um repertório formal, resgatado da arquitetura clássica.

o estudo das formas, elementos e soluções empregadas pelos antigos em seus edifícios constituía uma parte importante da formação dos arquitetos. Murray ${ }^{52}$ sinaliza que, em suas várias estadas em Roma, Brunelleschi teria se dedicado ao estudo dos princípios construtivos de edifícios antigos que as ruínas romanas sugeriam. De acordo com Tavares"53 "há referência a que terá desenhado e medido, em alçados aproximados, quase todos os edificios antigos da época imperial na cidade e em muitos lugares dos arredores." A partir desses estudos é que ele teria desenvolvido o sistema construtivo da cúpula de santa Maria del Fiore, o Duomo de Florença.

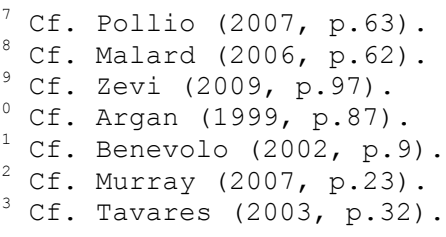


O trabalho do arquiteto consistia em estudar os vestígios da antiguidade, ordenar seus fragmentos e reconstruir o original, sem a interferência dos acréscimos e alterações que pudessem ter sofrido ${ }^{54}$. Para isso o emprego do desenho era fundamental, de acordo com Lancha 55, "A obra de arquitetura possui uma determinada consistência e um absoluto encerramento: os desenhos servem para decompor essa consistência e romper seu hermetismo".

A confecção de cadernos de desenho se tornava comum Florença. Chamados de taccuini, eles se tornavam verdadeiros catálogos antiquários confeccionados com textos e desenhos realizados in loco ou mesmo a partir de desenhos produzidos por outros arquitetos. O Taccuino Senese ${ }^{56}$, de Giuliano da Sangallo, foi um dos cadernos de desenho amplamente copiados por outros artistas. A organização das ilustrações utilizada por Andrea Palladio no quarto livro de seu tratado se assemelha muito a algumas páginas do Taccuino Senese ${ }^{57}$.

Em edifícios como o Ospedale degli Innocenti, ou a Basilica di San Lorenzo, Brunelleschi emprega colunas com capitéis coríntios, arcos plenos ${ }^{58}$ e abóbadas perfeitamente esféricas, elementos resgatados da antiguidade clássica e que remetem à perfeição do círculo. Thoenes ${ }^{59}$, ao buscar a origem do emprego das ordens clássicas na arquitetura do Renascimento, afirma que Brunelleschi foi aquele que primeiramente conseguiu analisar as estruturas românicas e romanas e obter um sistema tectônico que somente com a palavra ordem é descrito adequadamente. "Através da perspectiva era possível dominar o espaço, suas regras de articulação, os efeitos da luz, da sombra, da distância, da altura e da profundidade" 60 . A construção era submetida a um módulo que determinava não somente a proporção entre seus elementos, mas todo o efeito visual que ela proporcionava ${ }^{61}$.

54 Cf. Thoenes (2003, p.11).

${ }^{55}$ Cf. Lancha $(2006$, p.51).

56 Cf. Souza (2006, p.65).

57 Argumento que será retomado no capítulo 3.

58 Brandão (2000, p.83) afirma que, para os arquitetos do período, o arco pleno era perfeito e se ligava geometricamente aos demais elementos do edifício por meio do seu raio.

${ }_{59}$ Cf. Thoenes (1998, p.126).

60 Malard $(2006$, p.62).

${ }^{61}$ Cf. Heydenreich (1998, p.24). 
Não bastava somente conhecer as ruínas e edifícios clássicos, era necessário um método racional para a aplicação dessa linguagem à arquitetura do Renascimento. A normalização dessas formas visava possibilitar o destaque dos valores proporcionais na composição dos edifícios ${ }^{62}$, independentemente do significado que tinham antigamente.

Os artistas do Renascimento não buscavam na Antiguidade Clássica apenas um repertório formal, mas as leis matemáticas fundamentais que estavam ocultas na natureza e que os antigos teriam decifrado e aplicado na arte ${ }^{63}$. Tratava-se da "crença num ideal ordenador, que constrói a própria natureza, que a submete a um rigoroso canon e afirma a racionalidade humana, a história humana e a cultura frente à natureza imediata" ${ }^{64}$.

"quando falamos do classicismo da arquitetura
renascentista, falamos, dombém,
antropocentrismo e do humanismo nela presentes, e
pretendemos mostrar que tais traços se encontram
intimamente ligados às leis matemáticas que
construíam, um edifício e uma visão do universo.
Conclui-se, então, que a arché do quattrocento é
retirada da natureza geometrizada e da história, e
que a arquitetura daí resultante expressa um novo
indivíduo e uma nova relação com o mundo". ${ }^{65}$

De fato, a forma como os renascentistas empregam a linguagem clássica não é exatamente um retorno ao antigo, mas uma tentativa de diminuir a distância entre teoria e prática nos próprios projetos. Buscava-se um instrumento capaz de embasar teoricamente a aplicação dessa linguagem à arquitetura do seu tempo. O importante era o novo comportamento do arquiteto frente aos exemplares clássicos: ao invés de copiá-lo como tal, saber extrair as regras sobre as quais a arquitetura renascentista se funda ${ }^{66}$.

Brandão ${ }^{67}$ aponta as características que, para ele, são as mais importantes na arquitetura renascentista: a modulação com base nas ordens clássicas que, com a repetição de intercolúnios regulares, expressaria a típica visão racional capaz de ordenar

${ }^{62}$ Cf. Benevolo (2002, p.4).

63 Cf. ARGAN, G.C. El concepto Del espacio arquitectónico desde El Barroco a nuestros dias. Trad. Liliana Rainis. Buenos Aires: Nueva VIsión, 1961. p.15,16 e 27, apud Brandão (1999, p.71)

64 Brandão (1999, p.71-72) .

65 Idem.

${ }^{66}$ Cf. Thoenes (1998, p.126).

67 Ibidem p.80. 
e sistematizar o espaço; a simetria que, mais do que destacar o ponto central da perspectiva, seria um importante princípio na ordenação homogênea das partes do edifício; a composição de todo o edifício com uma mesma lei geométrica, demonstrando uma nova concepção matemática do universo; e a centralidade espacial, obtida através da utilização de esquemas e repertórios arquitetônicos baseados no círculo e na planta em cruz grega.

Assim como as formas passaram a ser empregadas em um contexto totalmente novo e com finalidade muito diferente daquela em que foram concebidas na antiguidade clássica, também a função estrutural desses elementos foi bastante modificada durante o Renascimento. Imitava-se a massa, mas apenas formalmente, muitas vezes, por trás de uma aparência robusta e maciça, se escondia uma estrutura extremamente leve e delgada. As formas clássicas podiam compor apenas um cenário, representando funções que já não mais desempenhavam. Muito diferente do que ocorria na arquitetura gótica, na renascentista, aos poucos, estrutura e forma se desvincularam, abrindo espaço para uma maior precisão na delimitação do campo de atuação do arquiteto:

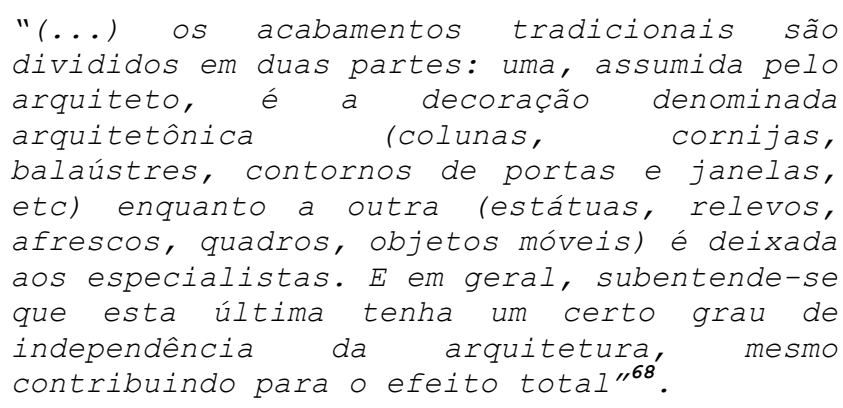

Christof Thoenes ${ }^{69}$ propõe alguns pontos acerca dessa ilusão criada pelos arquitetos renascentistas, para imitar os antigos romanos: o pilar não é o que aparenta - estrutura e aspecto visual são desvinculados; a fachada renascentista cria a imagem de massa, mascarando uma estrutura delgada, onde a imitação visual das formas romanas é feita sobre um substrato

${ }^{68}$ Cf. Benévolo (1972, p.149).

69 Cf. Thoenes (1998, p.59-61-69), tradução da autora, do italiano: "Il ruolo portante che la colonna ha implicito nella sua forma e che essa ha anche effettivamente svolto in Brunelleschi come sostegno dell'arco, adesso è diventato soltanto una finzione nel sistema dell'ordine inquadrante, una pura aparenza." 
técnico moderno; quando surgiam conflitos entre a estrutura e a forma, decorrentes dessa imitação, para manterem-se fiéis à forma romana, os renascentistas optavam pela ilusão e omitiam a verdadeira estrutura. Ainda segundo o autor "a função portante que a coluna traz implícita em sua forma e que ela efetivamente desempenhou em Brunelleschi, como sustentação do arco, agora se tornou somente um fingimento no sistema das ordens emoldurantes, somente aparência".

Para Thoenes"70, "pode-se deduzir que o pilar renascentista não é aquilo que aparenta, estrutura e aparência se separam. (...) Imitando a bela 'maneira' da arquitetura antiga - isto é, renunciando à realidade material do ato imitativo - criou-se a ilusão de seu renascimento." O autor fala em ilusão de renascimento porque, como passaram a ser empregadas nesse período, as formas clássicas nunca existiram anteriormente. Para ele, o que se chama de redescoberta, na verdade teria sido uma série de tentativas de reconstruir um sistema que, como tal, nunca tinha existido; se tratava de uma construção moderna, mas com formas antigas. Benevolo defende que essa era uma escolha consciente e intencional ${ }^{71}$ : "pela primeira vez, a cultura arquitetônica se subtrai a uma tradição dada e lhe contrapõe uma tradição escolhida, não aceita o passado como é, mas reivindica o direito de realizar uma avaliação e uma discriminação crítica".

Não se pretendia repetir as formas do passado, mas buscava-se "um reencontro com a grandeza perdida do império romano, procurando (...) a afirmação da sua identidade com um passado reivindicado como próprio, num processo de autoafirmação nacionalista" ${ }^{72}$, especialmente no momento que a península itálica atravessava.

\section{Os tratados e a profissão de arquiteto}

Quase no final do primeiro livro do De re Aedificatoria, aparece a primeira referência feita por Alberti às ordens clássicas, deixando claro o ideal de empregar as referências

70 Cf. Thoenes (1998, p.59-63), tradução da autora, do italiano: "Se ne deduce che Il pilastro rinascimentale non è quello che sembra: struttura e aparenza visiva sono scisse; (...) Imitando la bella 'maniera' dell'architettura antica cioè, rinunciando alla realtà materiale dell'atto imitativo - si creò l'illusione della sua rinascita."

71 Cf. Benevolo (1972, p.143).

72 Cf. Tavares (2003, p.19). 
antigas, não no intuito de copiar o que foi desenvolvido anteriormente, mas de emular essa tradição:

\begin{abstract}
"Desde o momento que até mesmo os mais famosos arquitetos demonstraram apreciar nas suas obras a partição dórica, jônica, coríntia ou toscana como a melhor das soluções, não por isso nas nossas obras devemos seguir literalmente os seus preceitos como se fossem normas indiscutíveis, mas preferivelmente, inspirados pelo desejo de produzir novas soluções, tentaremos conseguir uma fama semelhante à deles, ou se possível maior. "73
\end{abstract}

Após ele, Filarete, no oitavo livro de seu tratado, relaciona o tipo de coluna a ser empregado com a destinação dos edifícios. São três ordens de colunas para três diferentes tipos de homens ${ }^{74}$ : para a nobreza, próxima do príncipe, a ordem dórica; para a classe intermediária, útil, mas que oferece menos adornamentos que os gentis, a ordem coríntia; no lugar mais baixo, estão os mais ínfimos, trabalhadores que se fadigam, representados pelo estilo jônico.

O tratado de Serlio, ainda que tenha recebido ilustrações de qualidade desigual em suas primeiras edições (em função dos limites da xilogravura ${ }^{75}$ e da capacidade técnica dos artesãos anônimos que a realizavam), teve um papel importante pois foi "o primeiro também a ter encontrado uma clientela no mercado do livro e invertido a relação entre o texto e a imagem: Serlio escolheu apresentar desenhos comentados, e foi precisamente esse expediente que garantiu o sucesso do seu livro"76. Também foi ele o primeiro a concretizar em seu tratado a noção de ordem, com uma sistematização das formas recuperadas da antiguidade clássica.

73 Cf. Alberti (2010, p.35), tradução da autora, do italiano: "Dal momento che anche i più famosi Architetti hanno dimostrato di apprezzare nelle loro opere la partizione dorica, ionica, corinzia o tuscanica come la migliore delle soluzioni, non per questo nelle nostre opere dobbiamo seguire alla lettera i loro precetti come fossero dettami indiscutibili, ma piuttosto, ispirati dal desiderio di mettere a punto nuove soluzioni, cercheremo di conseguire una fama pari alla loro, o se possibile maggiore."

74 Cf. Thoenes (1998, p.72).

75 A xilogravura consiste em entalhes sobre placas de madeira. A técnica de impressão depende das diferenças de profundidades entre os entalhes. A tinta se deposita na superfície da matriz e é transferida para o suporte com a aplicação de pressão manual sobre o verso da placa. Dessa forma, ela não permite a expressão de detalhes muito pequenos.

${ }^{76} \mathrm{Cf}$. Thoenes (2003, p.15). 
Vignola, por sua vez, aperfeiçoou essa noção propondo um método normatizado para o uso das formas clássicas. Ele não só formulou regras para a aplicação das proporções e formas, como também estabeleceu critérios próprios de projeto para cada uma das ordens.

Os tratados de Danielle Barbaro, Andrea Palladio e Vincenzo Scamozzi, foram ricamente ilustrados. Nesse momento, grande parte da reprodução das ilustrações já era feita por meio da gravura em metal, especialmente 0 cobre ${ }^{77}$, o que garantia maior qualidade e, principalmente, maior uniformidade nas cópias.

Palladio faz uma abordagem inovadora das ordens ao apresentá-las no mesmo livro que trata da materialização da construção. Assim, há uma justaposição dos materiais de construção, fundações, muros e outros elementos construtivos, à sistematização das ordens arquitetônicas. Por meio desse recurso ele deixa claro seu ponto de vista prático, em que os elementos para composição formal e material do edifício têm o mesmo peso, sendo apenas partes para combinação e obtenção do todo.

Vincenzo Scamozii, em Idea dell'architettura universale, fala das cinco ordens como um sistema estável, milenar e imutável:

"A própria natureza, do princípio do mundo até nossos dias sempre teve uma mesma ordem (...) e assim continua; e quanto aos povos, nos primeiros tempos após o Dilúvio Universal a Itália se contentou com apenas uma ordem, que foi a Toscana. Depois os gregos se firmaram algum tempo com a ordem dórica; e depois progressivamente acrescentaram a Jônica, e igualmente a Coríntia (...) e finalmente os romanos chegaram ao número quinário das ordens, e não o passaram jamais." ${ }^{78}$

\footnotetext{
77 Diferentemente da xilogravura, a gravura em metal permite a expressão de pequenos detalhes, já que a impressão ocorre em função do depósito de tinta nos próprios entalhes na superfície do metal. De acordo com o método de gravação utilizado, é possível obter diferentes efeitos com a gravura em metal. Outra vantagem que ela possui em relação à xilogravura, é que a matriz resiste a uma quantidade muito maior de impressões e, consequentemente, diminui o risco de alterações nos desenhos em função da imprecisão das cópias realizadas por artesãos.

${ }^{78}$ Cf. Scamozi, V. L'idea della architettura universale. Venezia, 1625, parte II, p.15 sg. Apud Thoenes (1998, p.125).
} 
$\mathrm{Na}$ Tabela 2 estão reunidos os tratados de arquitetura desenvolvidos nesse período ${ }^{79}$. Mallard ${ }^{80}$ usa a Lei dos três estados de Focilion (1945), para analisar as fases do Renascimento. Segundo essa lei, todo estilo passa por três estados: pré-clássico, de formação, com experimentações de ideias novas; clássico, apogeu do estilo, caracterizado por grande harmonia do conjunto; e barroco, com transformações em que há ruptura com a harmonia plástica.

Essa crise na produção do período também teria se refletido nos tratados, como se os primeiros fizessem uma ampla análise, com a grande responsabilidade de delimitar a área de atuação e o campo de conhecimentos dos arquitetos. Os últimos, por sua vez, encontravam processos e vocabulários de projeto consolidados, cabendo a eles o trabalho de sintetizar o que ainda lhes interessava.

\begin{tabular}{|c|c|c|}
\hline Autor & Título original & Data \\
\hline Leon Battista Alberti & $\begin{array}{c}\text { De re aedificatoria libri } \\
\text { decem }^{81}\end{array}$ & $1442-1452$ \\
\hline $\begin{array}{l}\text { Antonio Averlino, dito } \\
\text { Filarete }\end{array}$ & $\begin{array}{c}\text { Codex Magiabechianus, II, } \\
\text { I, } 140\end{array}$ & Cerca de 1400-1465 \\
\hline $\begin{array}{l}\text { Francesco di Giorgio } \\
\text { Martini }\end{array}$ & $\begin{array}{c}\text { Codex Ashburnham } 361 \\
\text { Codex Saluzzianus } 148 \\
\text { Codex Magliabechianus II, } \\
\text { I, } 141\end{array}$ & $\begin{array}{c}\text { Cerca de } 1470-1490 \\
\text { Cerca de } 1482-1486 \\
1489-1492\end{array}$ \\
\hline Anônimo & Hypnerotomachia Poliphili & 1499 \\
\hline $\begin{array}{l}\text { Fra Giovanni Giocondo } \\
\text { da }\end{array}$ & $\begin{array}{l}\text { M. Vitruvius per locundum } \\
\text { solito castigatior }\end{array}$ & 1511 \\
\hline
\end{tabular}

79 Cf. Evers (2003).

80 Cf. Mallard (2006, p.72).

${ }^{81}$ Verônica Biermann (EVERS, 2003, p.22) traduz o título em português para 'Dez Livros sobre a Arquitetura', mas atualmente as novas traduções tendem a incorporar no título a vertente artística que se pretendia para a arquitetura à época. Em 2010 foi realizada uma edição em italiano, coordenada por valeria Giontella, e o título foi traduzido como 'L'arte di construire'; em 2011 foi publicada uma edição portuguesa, coordenada pelo professor Mario Krüger, da Universidade de Coimbra. Essa edição foi traduzida diretamente do latim, e intitulada 'Da Arte Edificatória'; por fim, em 2012 foi realizada a primeira edição brasileira do tratado, organizada pelo linguista sergio Romanelli, cujo título foi 'Da Arte de Construir'. 


\begin{tabular}{|c|c|c|}
\hline Verona & $\begin{array}{l}\text { factus, com figuris et } \\
\text { tabula, ut iam legi et } \\
\text { intellegi possit }\end{array}$ & \\
\hline Sebastiano Serlio & $\begin{array}{c}\text { Tutte l'opere } \\
\text { d'architettura et } \\
\text { prospettiva }\end{array}$ & 1619 (1517) \\
\hline Cesare Cesariano & $\begin{array}{l}\text { Di Lucio Vitruvio } \\
\text { Pollione de Architectura }\end{array}$ & 1521 \\
\hline Pietro Cataneo Senese & $\begin{array}{c}\text { I Quattro Primi Libri di } \\
\text { Architettura }\end{array}$ & 1554 \\
\hline Daniele Barbaro & $\begin{array}{c}\text { I Dieci Libri } \\
\text { delI'Architettura di } \\
\text { M.Vitruvio }\end{array}$ & 1556 \\
\hline $\begin{array}{lll}\text { Jacopo } & \text { Barozzi } & \text { da } \\
\text { Vignola } & & \end{array}$ & $\begin{array}{l}\text { Regola Delli Cinque } \\
\text { Ordini d'Architettura }\end{array}$ & 1562 \\
\hline Andrea Palladio & $\begin{array}{l}\text { I Quattro Libri } \\
\text { Dell'architettura }\end{array}$ & 1570 \\
\hline Vincenzo Scamozzi & $\begin{array}{c}\text { L'idea dell'architettura } \\
\text { universale }\end{array}$ & 1615 \\
\hline
\end{tabular}

Tabela 2 - Compilação dos tratados de arquitetura desenvolvidos no arco temporal do Renascimento. Adaptado de Evers (2003).

De Fusco ${ }^{83}$ também aponta nesse sentido ao afirmar que a contração que podia ser percebida nos textos ao longo do tempo denotaria uma crise no gênero tratadístico:

"(...) o tratado de Palladio é também uma obra sintética. Não é por acaso que os dez livros de Vitruvio e Alberti, os vinte e cinco de Filarete, os sete de Francesco di Giorgio, os oito de Serlio (...) se reduzem

\footnotetext{
${ }^{82}$ O título desse tratado é bastante significativo e representativo das críticas feitas ao texto de Vitruvio: 'M.Vitruvio, Expurgado dos seus erros por Giocondo, com ilustrações e um índice das Matérias a fim de ser lido e compreendido'.

${ }^{83} \mathrm{Cf}$. De Fusco (2003, p.488), tradução da autora, do italiano: "Il trattato di Palladio è anche un'opera sintetica. Non è un caso che i dieci libri di Vitruvio e di Alberti, $i$ venticinque del Filarete, $i$ sette di Francesco di Giorgio, gli otto do serlio (...) si riducono ai soli quattro dell'opera palladiana. Questa contrazione segna indubbiamente una crisi del genere trattatistico, come dimostra la fortuna dell'unico volumetto manualistico del Vignola, ma denota anche l'inizio d'una fusione tra riflessione critica e attività operativa, fra teoria e storia dell'architettura. Pertanto, un altro carattere nuovo del trattato di Palladio, anche se anticipato da quello di Serlio, sta in ciò che esso è indissociabile dalla storia delle sue opere di architetto."
} 
aos somente quatro da obra paladiana. Esta contração assinala sem dúvida uma crise no gênero tratadístico, como demonstra o sucesso do único volume manualístico de Vignola, mas demonstra também o início de uma fusão entre reflexão crítica e atividade operativa, entre teoria e história da arquitetura. Portanto, uma outra característica nova do tratado de Palladio, ainda que antecipada por aquele de Serlio, está nele ser indissociável da história das suas obras como arquiteto." 


\section{Desenvolvimento do território e surgimento das vilas}

No decorrer dos séculos XII e XIII, os centros urbanos da Itália central passaram por um grande desenvolvimento e isso, ao mesmo tempo em que contribuiu para o enfraquecimento da aristocracia rural, gerou um aumento na demanda por gêneros agrícolas que a produção feudal não estava preparada para satisfazer ${ }^{1}$. Foram realizadas intervenções no território desmatamento e a aragem de áreas rurais, e a drenagem de terrenos pantanosos - a fim de restituir o aspecto ordenado que ele havia perdido, além de ampliar as zonas cultiváveis ${ }^{2}$.

A organização espacial predominante na Itália era diferente do que se via na maior parte da Europa Ocidental, lá nunca predominaram os castelos isolados, distantes dos centros urbanos. As propriedades rurais dos italianos se organizavam em torno das capitais das províncias, já densamente urbanizadas, e com elas mantinham uma forte ligação desde a Antiga Roma ${ }^{3}$, e que não fora rompida nem mesmo no sistema feudal.

O que começava a mudar, nesse momento, era o perfil dos proprietários de terras pois, uma vez que a burguesia mercantil crescia e prosperava nas cidades, ela passava a ver no campo um local onde investir parte de seus ganhos. "Os habitantes das cidades, de qualquer classe social, que tivessem alguma parcela de renda disponível teriam adquirido propriedades agrícolas"“4.

Assim como acontecia na Idade Média, no Renascimento a arquitetura estava atrelada ao poder, mas esse poder não estava mais centralizado na Igreja. "O Estado passa a ter presença tão importante - e até mais - do que a Igreja. O palácio do governante autocrático entra no cenário urbano competindo, em termos simbólicos, com os templos religiosos." ${ }^{5}$

Na Itália tardo-medieval, muitos nobres feudais passaram a construir palácios com torres defensivas nas cidades, mas suas residências principais continuavam sendo os castelos fortificados erigidos em suas propriedades rurais. Eles eram simbólica e materialmente centros de poder e influência, e sua antiguidade era valorizada como uma demonstração da nobreza em

\footnotetext{
Cf. Ackerman (1992, p.90).

Cf. Visentini (1995, p.41).

3 Burns (2012, p.24). O autor ainda destaca que a exceção se dava pelos venezianos que possuíam terras na região de Verona.

4 Burns, (2012, p.26). Tradução da autora, do italiano: "Gli abitanti delle città, di qualsiasi classe sociale, che si fossero trovati ad avere una quota di reddito disponibile avrebbero acquistato fondi agricoli."

${ }^{5}$ Cf. Malard (2006, p.63)
} 
relação à burguesia e remontava à tradição em um período de grandes transformações ${ }^{6}$.

Por outro lado, o domínio das cidades, ou a participação nesse domínio, passava a ser importante para a manutenção do poder econômico e político também no campo. Nas cidades onde não viviam príncipes, como Bolonha, Verona e Vicenza, a nobreza feudal participava do poder local por meio de conselhos citadinos e outros organismos semelhantes, sobrepujando os setores que detinham o controle até então ${ }^{7}$.

Percebe-se que, apesar de ser um tipo de edifício situado fora dos limites das cidades, a vila só pode ser compreendida a partir de sua relação com a cidade, pois "De fato, ela não existe para desempenhar funções autônomas, mas para contrabalançar valores e vantagens da vida urbana, e sua condição econômica é aquela de uma entidade satélite."8

Sobre isso, Corboz ${ }^{9}$ acrescenta que o fenômeno vila é paradoxal, pois, embora pareça uma manifestação típica do campo, "o comitente, o arquiteto, a tipologia, a expressão arquitetônica e assim por diante, provêm da cidade". Além disso, os recursos para manutenção da vila estão sempre associados à cidade, já que, do ponto de vista econômico, podese ter vilas em dois tipos de propriedades rurais, ambos dependentes de sua relação com as cidades: uma delas é a propriedade agrícola autossuficiente, que produz para consumo próprio e que gera lucro pela comercialização dos excedentes, que é feita no mercado citadino; e a outra é a vila concebida exclusivamente para deleite e cuja manutenção e funcionamento dependem de capitais excedentes das atividades urbanas de seu proprietário ${ }^{10}$.

Funcionalmente, as vilas eram mais próximas dos castelos, que também poderiam ser utilizados como repouso, e fonte de prazer ou estarem relacionados a atividades agrícolas, que às casas camponesas. Em função disso,

\footnotetext{
${ }^{6}$ Cf. Ackerman (1992, p.82-83).

Cf. Burns (2012, p.28).

8 Ackerman (1992, p.3). Tradução da autora, do italiano: "La villa non può essere compresa prescindendo dal suo rapporto con la città. Essa esiste infatti non per assolvere funzioni autonome ma per controbilanciare valori e vantaggi della vita urbana, e la sua condizione economica è quella di un'entità satellite."

${ }^{9}$ Cf. Corboz (1995, p.9).

10 Cf. Ackerman (1992, p.11-12). Nesse mesmo texto, o autor associa esse segundo modelo de vila a Alberti, mas no capítulo 3 vê-se que, no decorrer de sua obra, Alberti falou em diferentes tipos de vila e esse é somente um deles.
} 


"A casa camponesa tende a ser simples na
estrutura e a conservar formas
inveteradamente tradicionais, que não
implicam na intervenção de um projetista. Ao
contrário disso, a vila é o produto típico
da capacidade criativa de um arquiteto e
documenta a modernidade". 11

Com o aumento da segurança nos campos, os castelos e as residências fortificadas foram perdendo espaço para edifícios mais abertos e com maior liberdade compositiva que nas cidades, já que lá não existiam as limitações impostas pelas edificações vizinhas ou pelas dimensões e forma do terreno. A vila passava a ser vista como um instrumento de autorrepresentação, para dar visibilidade ao proprietário e ao arquiteto de pequeno grupo, que se diferenciava das práticas corriqueiras de construção de casas de campo, pois estavam imersos em experimentação e inovação ${ }^{12}$.

\section{Viver no campo na Antiguidade Clássica}

Havendo interesse tanto pela vida nos campos quanto pela antiguidade clássica, os renascentistas naturalmente se voltaram aos autores clássicos e às ruínas em busca de interlocutores e referências. Ao contrário do que aconteceu em relação a outros tipos de edifício, não havia exemplares de vila disponíveis para estudo entre as ruínas que se conhecia ${ }^{13}$ e, além disso, o tratado de Vitruvio também não permitia o esclarecimento dessas questões ${ }^{14}$.

A maior parte orientações para o projeto de residências que Vitruvio ${ }^{15}$ apresentou em seu tratado era direcionada para a construção de casas urbanas: tipos e medidas principais dos compartimentos (átrio, alas, tablino, etc); disposição das janelas; orientação dos compartimentos da casa; separação das

\footnotetext{
11 Ackerman (1992, p.3). Tradução da autora, do italiano: "La casa colonica tende a essere semplice nella struttura e a conservare forme inveteratamente tradizionali che non implicano l'intervento di un progettista. La villa è invece il prodotto tipico della capacità creativa di un architetto e ne documenta la modernità."

12 Cf. Burns (2012, p.37).

13 Não havia exemplares de vilas romanas que tivessem resistido à queda do Império romano no século $V$, as escavações em Pompéia e Herculano só foram realizadas séculos mais tarde.

14 Segundo Ackerman (1992, p.18 e 82), havia uma imprecisão geral na descrição das vilas apresentada por Vitruvio. Ela era basicamente uma discussão acerca da ordem dos compartimentos próximos à entrada que diferia das habitações urbanas. 15 As orientações referentes às residências estão no tratado de Vitruvio (2007), Livro VI. Do Capítulo III ao V (p.301-313) são tratadas as casas urbanas. No Capítulo VI (p.314-318) são discutidas as construções específicas para propriedades rurais. Já no Capítulo VII (p.319-323) o autor apresenta brevemente as casas gregas e suas principais diferenças em relação às romanas.
} 
partes comuns e privadas da casa; e, por fim, um ponto que foi retomado posteriormente tanto por Alberti quanto por Palladio. São eles, a adequação da casa à função e estatuto do proprietário ${ }^{16}$.

$\mathrm{Na}$ sequência ele caracteriza as construções rurais e associa as vilas à ideia de salubridade e à sua exposição solar. Um diferencial importante é que, no texto de Vitruvio, a vila é toda a propriedade rural, que tem por finalidade a produção agrícola e pecuária e, de fato, quase todas orientações que ele dá ao projeto fazem referência às atividades que nela serão desempenhadas (localização dos currais, manjedouras, cozinha, armazém, etc.). Sobre a casa de vila ele fala somente quanto à iluminação natural dos compartimentos, afirmando que lá ela é mais facilmente obtida do que nos edifícios localizados na cidade. Além disso, ele explica que todas as diretrizes dadas para as residências urbanas também se aplicam às rurais:

"Essas normas, por outro lado, não se
aplicam apenas na cidade mas também no
campo, com a diferença de que na cidade os
átrios costumam ficar mais próximos das
portas e, no campo, surgem logo peristilos
de tipo urbano e só depois vêm os átrios,
apresentando em volta pórticos pavimentados
voltados para palestras e passeios."17

Se, por um lado, o texto de Vitruvio não apresentava muitas orientações para o projeto de vilas, por outro, os tratados agronômicos publicados pelos antigos romanos ${ }^{18}$, nos quais estavam as raízes literárias da exaltação dos prazeres do campo, em oposição aos vícios e excessos citadinos ${ }^{19}$. Percebe-se que a vila era mais do que um centro de produção agrícola e a busca por lucros caminhava ao lado da busca pelos prazeres oriundos da vida no campo, que também é consequência da difusão da cultura helenística e da configuração do otium.

Vinda desde os ensinamentos de Epicuro (341-270 a.C), a valorização do tempo livre de ocupações e dedicado às atividades intelectuais, foi posteriormente definido por Cícero (106-43 a.C) como otiumº em oposição ao negotium:

"O termo negotium, a que Horácio atribui no verso citado («Beatus qui procul negotiis...

\footnotetext{
${ }^{6}$ Cf. Vitruvio, Livro VI, Cap. V (2007, p.311).

Cf. Vitruvio, Livro VI, Cap. V (2007, p.313).

Cf. Visentini (1995, p.41).

9 Cf. Ackerman (2009, p.7).

${ }^{20}$ Cf. Visentini (1995, p.14).
} 
») o significado de ocupação, tarefa, preocupação, dificuldade, como os outros autores latinos, constitui a antítese perene do otium, o tempo livre dos afazeres, condição ideal da vida campestre na mente dos cidadãos romanos". 21

Nos principais tratados agronômicos romanos que eram conhecidos - aqueles de Catão (234-149 a.C), Varrão (116-27 a.C) e Columella (séc.I) - foi registrada uma parte da evolução da vila romana conhecida como villa-fattoria, que era aquela vinculada a uma propriedade rural ${ }^{22}$.

No texto de Catão, a vila aparece como uma moradia muito simples e funcional e dotada de mínima comodidade, e era chamada de villa rustica. Posteriormente, Varrão retoma essa definição e a contrapõe à de villa urbana, que seria uma residência rural nos moldes das habitações urbanas e voltada para o prazer do proprietário e de seus hóspedes, que critica duramente ${ }^{23}$.

Esses dois textos quase pregam a austeridade das habitações como forma de se distanciar de tudo que estava relacionado com a cidade,

"próximos do estoicismo em seu tom asséptico
e moral, exortam o homem de negócios da
cidade a adquirir uma modesta casa rural em
uma pequena propriedade e a cultivar a terra
com pouca ou nenhuma ajuda; o próprio
trabalho manual é considerado como meio de
purificação das contaminações da cidade." ${ }^{24}$

Columella já apresenta uma descrição mais completa da vila relacionada às atividades agrícolas, composta por diversos edifícios. A villa urbana é a residência rural do proprietário, dotada de conforto e elegância, e a villa rustica, é a residência dos empregados, escravos e espaços para criação de animais. Ele ainda acrescenta a villa fructuaria, que é o edifício destinado ao trabalho dos grãos e produtos agrícolas ${ }^{25}$.

Outros dois tipos de vila que não são discutidos por Columella, por não serem destinados à atividade agrícola são a

\footnotetext{
21 Ackerman (1992, p.41). Tradução da autora, do italiano: "Il termine negotium cui Orazio nel verso citato («Beatus qui procul negotiis...») attribuisce come gli altri autori latini il significato di occupazione, affare, preoccupazione, difficoltà, costituisce l'antitesi perenne dell'otium, il tempo libero dalle occupazioni, condizione ideale della vita campestre nella mente dei cittadini romani."

22 Cf. Ackerman (1992, p.43).

23 Cf. Ackerman (1992, p.43-45).

${ }^{24}$ Cf. Ackerman (2009, p.3).

25 Cf. Ackerman (1992, p.51).
} 
villa suburbana, que é uma residência imediatamente fora dos limites da cidade e a villa marítima, que como o próprio nome sugere está localizada próxima do mar (Figura 4).

Em relação à forma das vilas da Roma Antiga, dois modelos se destacam. No primeiro modelo tem-se uma ampla estrutura aberta e assimétrica, que se integra com o terreno onde está inserida numa espécie de abraço - com o edifício envolvendo a paisagem ${ }^{26}$. Essa tipologia pode ser percebida na Villa Adriana ${ }^{27}$, em Tivoli, cuja conformação sugere que o desenvolvimento não segue um planejamento inicial para os acréscimos que vão sendo realizados ao longo do tempo, ainda que os edifícios estejam ligados entre si.

Já o segundo modelo tem estrutura cúbica e forma compacta, que se relaciona com o terreno de forma oposta à anterior, por meio de seu isolamento - nesse caso o edifício não envolve a paisagem, mas é envolvido por ela. Essa conformação é frequentemente empregada em subúrbios densamente povoados, como ocorria na Villa dei Misteri e outras vilas de Pompeia (Figura 5).

Mais tardiamente, as duas vilas de Plínio o Jovem (cerca de $61 \mathrm{~d} . \mathrm{C}$ a $112 \mathrm{~d} . \mathrm{C})$, constituíram o modelo mais maduro produzido na antiguidade ${ }^{28}$. Embora não tenham resistido ao tempo ${ }^{29}$, essas vilas foram estudadas no Renascimento a partir das descrições realizadas por Plínio em suas Epístolas.

\footnotetext{
${ }^{26}$ Cf. Ackerman (1992, p.18-19).

27 Construída entre 118 e 138d.C pelo Imperador Romano Adriano (Publius Aelius Hadrianus 76-138d.C) durante quase todo o tempo em que ele esteve à frente do Império.

${ }_{28}$ Cf. Ackerman (1992, p.7).

29 Somente no século XX foram realizadas escavações nos dois sítios, trazendo à luz algumas ruínas das vilas de Plínio o Jovem.
} 

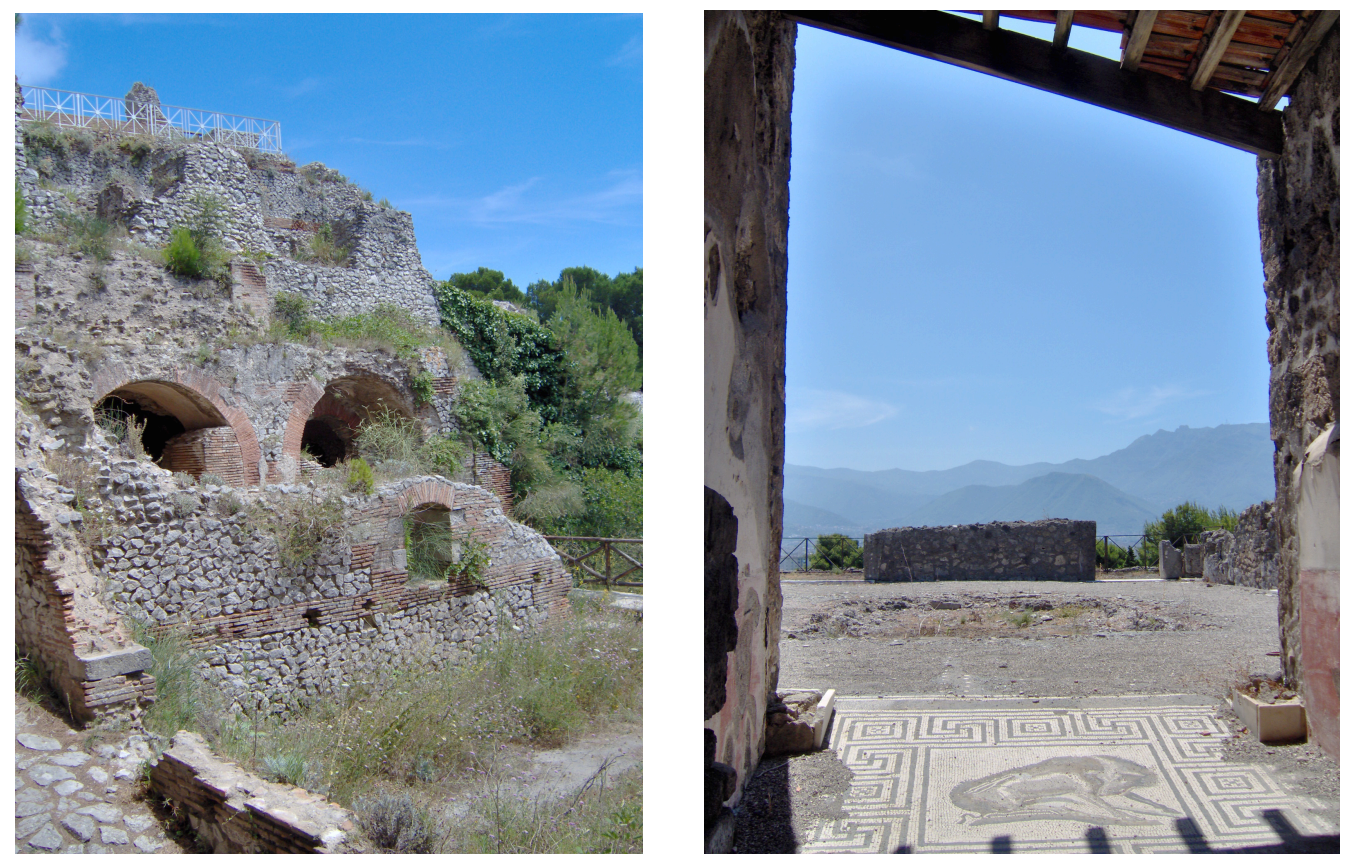

Figura 4 - Ruínas de Villa Iovis (esq.), situada em Capri. Uma das doze residências de Tibério (42 a.C a 37 d.C). Figura 5 - Ruínas de vila em Pompeia, onde se vê a paisagem ao fundo (dir.). 
Uma das vilas de Plínio, chamada Laurentinum, situava-se em Vicus Augustanus, uma pequena localidade próxima a Roma ${ }^{30}$, que não tinha finalidade agrícola, mas era utilizada para repouso e diversão aos finais de semana. A outra, chamada Tusci, se situava em Tifernum Tiberinum ${ }^{31}$ uma localidade na divisa entre Umbria e Toscana. Ao contrário da primeira, a vila de Tusci era destinada a períodos de permanência prolongados e abrigava atividades agrícolas, como o cultivo de vinhedos ${ }^{32}$. Além do tipo de uso, as duas vilas de Plínio também diferiam quanto à forma, enquanto a vila Laurentinum possuía forma compacta (Figura 6), a vila Tusci se distribuía de forma mais dispersa no terreno.

Nessa época, frequentemente as vilas eram localizadas no ponto mais alto do terreno, como o topo de uma colina ou a encosta de um morro, de onde fosse possível dominar visualmente seu entorno e, principalmente, a cidade com que ela se relacionava ${ }^{33}$. Se, por um lado, as duas vilas de Plínio apresentavam funções e formas diferentes, provavelmente ambas eram implantadas de forma a valorizar seu entorno.

"As repetidas descrições, que Plínio faz das
visuais que se pode admirar das janelas dos
vários ambientes de suas vilas, sugerem que
a implantação arquitetônica de suas duas
residências pode ter sido condicionada por
uma posição panorâmica particularmente
fascinante e bela"

\footnotetext{
30 Englobada por Roma, hoje essa localidade faz parte de uma das propriedades da Presidência da República Italiana.

31 Atualmente a localidade onde as ruínas dessa vila estão localizadas se chama San Giustino, na província de Peruggia.

32 Cf. Ackerman (1991, p.64).

33 Cf. Ackerman (1992, p.26).

34 Cf. Ackerman (1992, p.71). Tradução da autora, do italiano: "Le ripetute descrizioni che Plinio fa delle vedute che si possono godere dalle finestre dei vari ambienti delle sue ville, suggeriscono che la pianificazione architettonica delle sue due residenze poteva essere stata condizionata da una posizione panoramica di particolare suggestione e bellezza."
} 


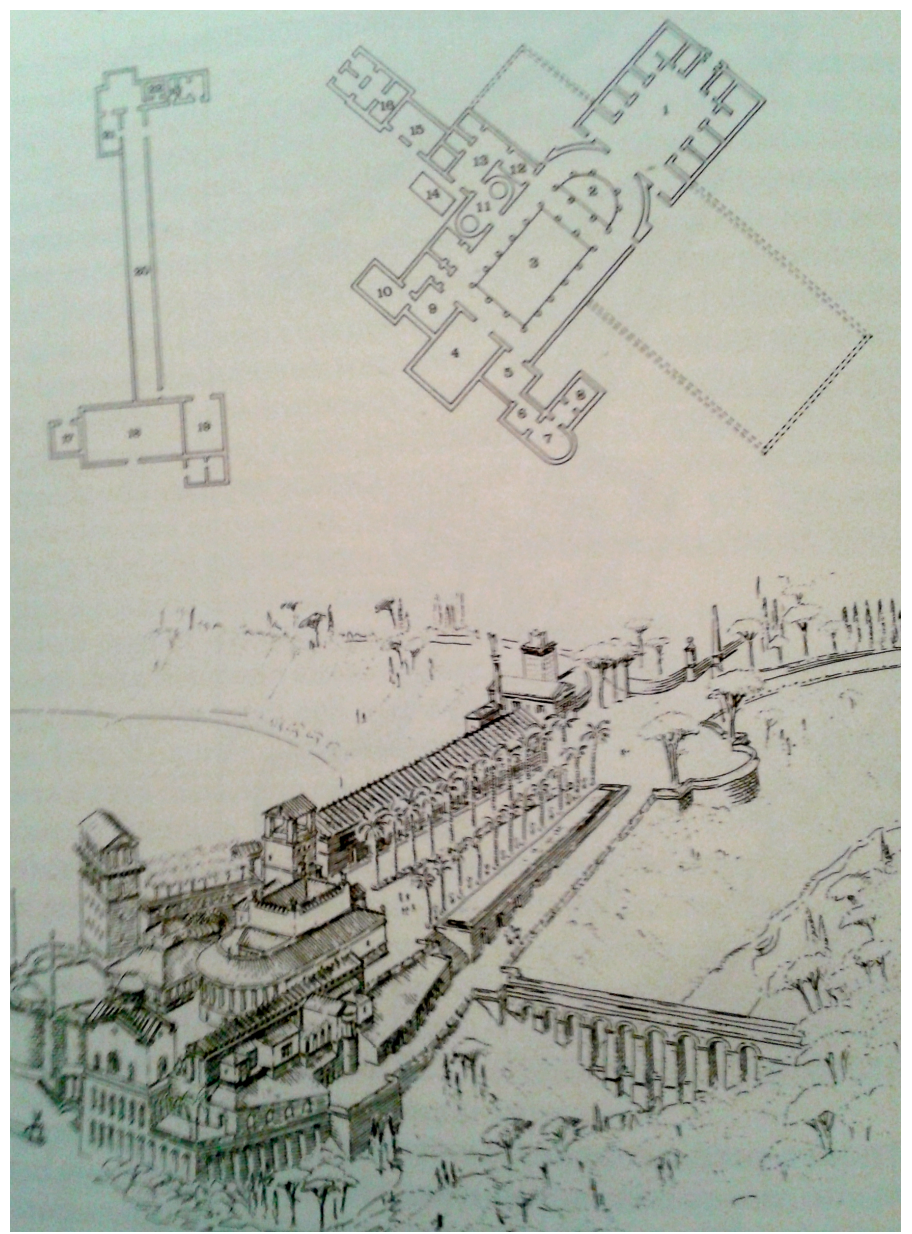

Figura 6 - Reconstrução em planta e perspectiva da Villa Laurentinum, de Plínio o Jovem. Fonte: Ackerman (1992, p.66). 
Por suas grandes dimensões, as descrições formais das vilas de Plínio eram pouco úteis a projetos de menor escala e orçamento, mas suas dissertações acerca dos prazeres da vida na vila, com suas paisagens e atividades recreativas, serviram de exemplo para os tempos vindouros"35: "nunca me encontro tão bem, seja intelectual ou fisicamente, como lá [na vila Tusci]. Treino meu espírito com as ocupações literárias e o corpo com a caça" ${ }^{36}$.

A ideologia e a literatura se voltavam à exaltação da vida no campo, onde esse viver em vila, para o proprietário da terra, era sinônimo de gozar das vantagens que ela propiciava ao corpo e ao espírito. Enquanto na cidade existiam os excessos, as doenças e os vícios, na vila o ambiente era saudável e purificador. "O significado da ideologia da vila é radicado no contraste entre campo e cidade, no qual as virtudes e os prazeres de um são apresentados em antítese aos vícios e excessos do outro" ${ }^{37}$.

"A história das residências de campo no ocidente foi marcada por uma constante: a ideologia, própria do habitante da cidade, da vida pastoral ou rústica, de um lugar com ar puro, espírito genuíno e relações humanas joviais, um lugar para se relaxar, mas também para fazer atividades físicas, sobretudo caça, um lugar caracterizado por vistas capazes de elevar o espírito, de tudo aquilo que era diverso da experiência da cidade. 138

Também contribuíram para a construção desse mito as três obras que o poeta Virgílio (70-19 a.C) dedicou à vida no campo: Bucoliche, Egloghe e Georgiche. O que o discurso de Virgilio acrescenta aos autores apresentados acima é que, para ele, o

\footnotetext{
35 Cf. Ackerman (2009, p.3).

36 Epístole V. VI. $45^{\prime}$ apud Ackerman, 1992, p.9. Tradução da autora, do italiano: "Non mi trovo mai cosí bene, sia intellettualmente che fisicamente, come là. Infatti tengo in allenamento il mio spirito con le occupazioni letterarie e il mio corpo con la caccia."

37 Cf. Ackerman (1992, p.7). Tradução da autora, do italiano: "Il significato dell'ideologia della villa è radicato nel contrasto tra campagna e città, nel quale le virtú e i piaceri dell'una sono presentati in antitesi ai vizi e agli eccessi dell'altra."

38 Ackerman (2009, p.3). Tradução da autora, do italiano: "La storia delle residenze di campagna in occidente è stata contrassegnata da una costante: l'ideologia, propria del cittadino, della vita pastorale o rustica, di un luogo per rilassarsi ma anche per fare attività fisica, soprattutto andando a caccia, un luogo caratterizzato da vedute in grado di elevare lo spirito, da tutto ciò che era diverso dall'esperienza della città."
} 
otium surgia como uma recompensa pelo trabalho duro que se executa nos campos.

Apesar dos exemplos citados na literatura fazerem referência a vilas de grandes dimensões, a maior parte das vilas romanas mais antigas reveladas pelas escavações arqueológicas, reunia as diferentes funções em um mesmo edifício de dimensões modestas. Pode-se ver em uma dessas vilas, datada do século I a.C e situada em Boscoreale, próximo a Pompeia, que não há distinção clara entre os espaços que eram destinados aos proprietários e aqueles de uso dos empregados. Um mesmo edifício (Figura 7) abrigava tanto a residência patronal quanto granários e espaços destinados à produção de vinho. A entrada do edifício está voltada diretamente para o pequeno pátio, onde ficavam os recipientes em que se armazenava o azeite e o vinho, sem átrio ou peristilo.

Em torno da metade do século XIV, o humanista Francesco Petrarca (1304-1374) teve papel de destaque no estudo dos textos clássicos e na reproposição do ideal de vida no campo e na vila, percebendo que havia um rico patrimônio de textos antigos acerca desse argumento ${ }^{39}$ :

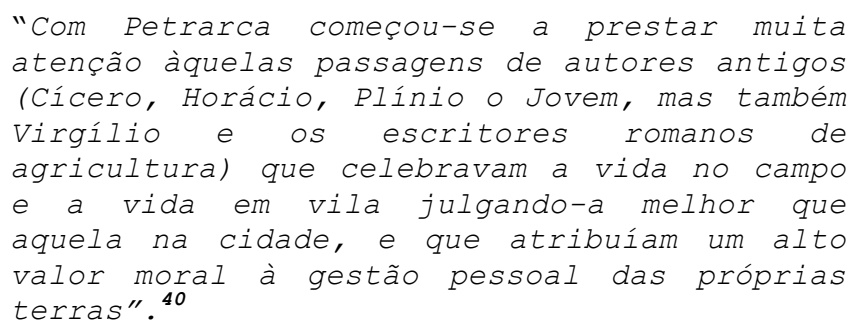

Giovanni Boccaccio (1313-1375) também contribuiu para a difusão do interesse pela vida no campo, ao refletir as ideias de Petrarca em seus livros de grande sucesso, especialmente o Decameron ${ }^{41}$. As cem histórias da coletânea são narradas por um grupo de dez jovens que tinha se refugiado da peste de $1348 \mathrm{em}$ uma vila no entorno de Florença ${ }^{42}$.

\footnotetext{
39 Cf. Burns (2012, p.36).

40 Burns (2012, p.33). Tradução da autora, do italiano: "Con Petrarca si cominciò a prestare molta attenzione a quei brani di autori antichi (Cicerone, Orazio, Plinio il Giovane, ma anche Virgilio e gli scrittori romani di agricoltura) che celebravano la vita di campagna e la vita in villa valutandole favorevolmente rispetto a quella di città, e che attribuivano un alto valore morale alla gestione personale del proprio fondo".

${ }^{41}$ Cf. Burns (2012, p.34).

42 Cf. Ackerman (1992, p.84).
} 


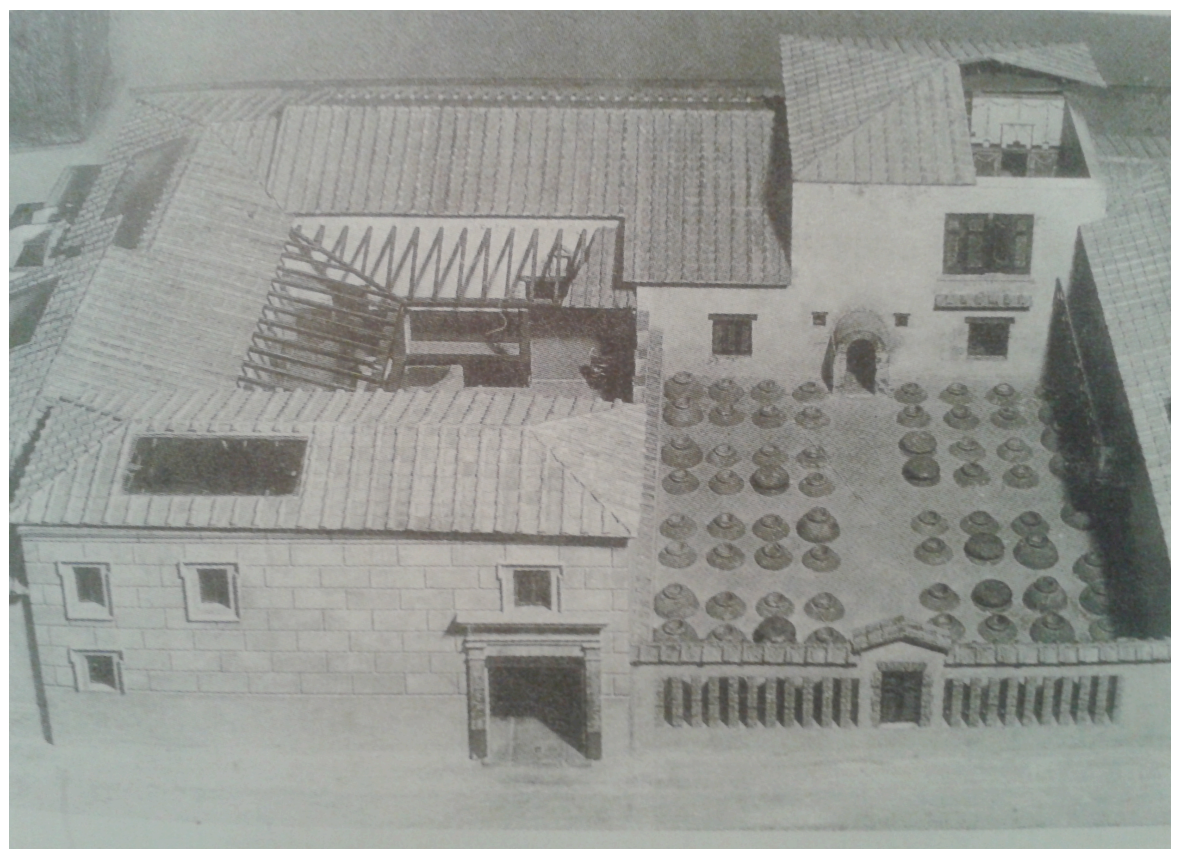

Figura 7 - Reprodução da vila romana de Boscoreale. Fonte: Ackerman (1992, p.55). 
Outro escritor renascentista importante para a
consolidação do ideal de vida no campo recuperado da antiguidade foi Pietro de' Crescenzi (1233-1320), que escreveu um livro sobre agricultura com informações trazidas de textos antigos e também com práticas contemporâneas. Esse livro foi publicado primeiramente em latim e logo traduzido para o italiano, sendo várias vezes impresso a partir do final do século XV.

Como se pode perceber,

"Os primeiros humanistas seguiram o exemplo
de Petrarca, evocando as vilas da
antiguidade com palavras antigas, ora
empregadas em referência as próprias,
provavelmente tradicionais, casas de campo.
Foi somente na metade do Quattrocento, com
Flavio Biondo (1342-1463) e Leon Battista
Alberti (1404-1472), que se difundiu um
conhecimento verdadeiro tanto dos textos
antigos pertinentes, quanto dos restos das
vilas romanas encontradas até o momento, e
consequentemente uma ideia aproximada do
aspecto da vila antiga"43

As interpretações dos modelos de vilas romanas no Renascimento foram feitas a partir de fontes literárias, e com as escavações realizadas em Pompeia e Herculano séculos mais tarde, mostraram-se ambíguas e até mesmo equivocadas. Foi somente a partir de Flavio Biondo (1392-1463) e Leon Battista Alberti (1404-1472) que se chegou a alguma ideia do aspecto da vila antiga ${ }^{44}$. Foi Alberti que, na primeira metade do século XV, assumiu o protagonismo da reproposição da antiga arquitetura de vila. "Ele leu Xenofonte e os autores romanos de agricultura e em seu texto juvenil Villa conseguiu juntar seus conselhos ainda úteis às práticas dos camponeses florentinos" ${ }^{45}$.

\footnotetext{
43 Burns (2012, p.38). Tradução da autora, do italiano: "I primi umanisti seguirono l'esempio di Petrarca, evocando le ville dell'antichità con parole antiche, ora impiegate in riferimento alle proprie, probabilmente tradizionali, case di campagna. Fu solo alla mettà del Quattrocento, con Flavio Biondo (13921463) e Leon Battista Alberti (1404-1472), che si diffuse una vera conoscenza sia dei testi antichi pertinenti sia dei resti delle ville romane giunte sino ad allora, e di conseguenza una qualche idea dell'aspetto della villa antica." 44 Cf. Burns (2012, p.38).

45 Burns (2012, p.39). Tradução da autora, do italiano: "Egli lesse Senofonte e gli autori romani di agricoltura, e nel suo breve componimento giovanile Villa fu in grado di mettere insieme i loro ancor utili consigli e la prassi dei contadini fiorentini."
} 


\section{Alberti e as vilas}

Leon Battista nasceu na cidade de Gênova em $1404^{46}$ e, entre 1416 e 141847, recebeu formação humanística em Latim, Retórica Antiga, Filosofia e Arte Poética, no Liceu de Pádua. Depois disso, frequentou a Universidade de Bolonha, onde começou a estudar direito. Ainda com vinte anos, ele escreveu uma comédia em latim que, por algum tempo, acreditou-se ser um dos manuscritos autenticamente antigos que estavam sendo redescobertos nesse momento ${ }^{48}$. Essa habilidade com a escrita era algo muito valorizado nesse momento,

"seja qual fosse a profissão liberal que escolhesse, ao jovem era solicitado uma capacidade básica: saber, isto é, como se servir de textos antigos defronte a problemas modernos. Era-lhes ensinado que obras escritas em um longínquo passado por autores pagãos ofereciam princípios que haviam uma relação direta com o seu mundo"."

Com a morte de seu pai antes que pudesse concluir os estudos, Alberti se viu sem proteção e suporte financeiro, optando então por adentrar ao meio universitário em Bolonha ${ }^{50}$ onde, em 1428, obteve a láurea em direito civil e canônico. Vários autores afirmam que, quando ainda estudava direito, Alberti teve um problema de saúde ${ }^{51}$, por isso resolveu se dedicar ao estudo das ciências naturais e artes visuais, como forma de se distrair.

\footnotetext{
46 Alberti é um dos dois filhos ilegítimos de Lorenzo Alberti, nobre banqueiro florentino que estava exilado em Gênova com sua família. Apesar do exílio, a família Alberti mantinha sua prosperidade econômica e, ainda que não fossem filhos legítimos, Leon Battista e seu irmão Carlo receberam de seu pai todas as condições necessárias para terem uma educação de excelente qualidade (Frommel, $2009, \mathrm{p} .45)$.

${ }_{47}$ Cf. Grafton (2003, p.7). Sobre isso, Biermann (EVERS, 2003, p. 22) acrescenta que Gasparino Barzizza, um dos maiores conhecedores de Cícero da sua época, foi responsável pela formação de Alberti no Liceu de Pádua.

${ }^{48}$ Cf. Murray (2007, p.47).

49 Cf. Grafton (2003, p.46), tradução da autora, do italiano: "Qualunque professione liberale sciegliesse, al giovane era richiesta una capacità di base: sapere, cioè, como servirsi di testi antichi di fronte a problemi moderni. Gli si insegnava che opere scritte in un passato da autori pagani offrivano principi che avevano un'attinenza diretta con il suo mondo".

50 Cf. Murray, A. Reason and Society in Medieval Europe. Oxford, 1978 apud Grafton (2003, p.44). As referidas universidades eram instituições que tinham o objetivo de produzir especialistas para determinadas funções de grande responsabilidade, necessárias para a vida de uma sociedade mercantil complexa e para o governo de uma cidade independente. Muitas vezes, essas instituições eram de administração municipal.

51 Cf. Grafton (2003, p.7) associa esse problema de saúde à preocupação de ter perdido o responsável pelo seu sustento. Além disso, uma observação interessante é que nesse período Alberti teria se dedicado ao estudo da natureza e das artes visuais para relaxar, uma argumentação que será recorrente na literatura albertiana sobre as vilas.
} 
Quando finalmente pôde se dirigir a Florença, em 1428, após a revogação do banimento de sua família, ele teve contato pela primeira vez com os novos edifícios e obras de arte que estavam sendo produzidos e com alguns de seus autores, como Brunelleschi, Donatello, Ghiberti e, provavelmente, Michelozzo.

Em 1431, Alberti adentrou à primeira das muitas cortes que viria a frequentar, tornando-se secretário de um representante do alto clero e, posteriormente, abreviador apostólico da cúria papal ${ }^{52}$. Já no exercício de suas novas funções, no início da década de 1430 Alberti foi a Roma e encontrou a cidade em uma crise decorrente da "perda progressiva dos valores da república, submergidos pela disputa do poder ao nível das oligarquias comerciais e financeiras."53

Em Roma ele se dedicou intensamente ao estudo dos edifícios clássicos, que estavam em condições precárias de conservação e escreveu o Descriptio urbis Romae ${ }^{54}$, que por muito tempo foi uma das principais referências sobre a cidade. A conservação dos edifícios se tornou um ponto tão importante para Alberti que, posteriormente, foi o tema do último livro do seu tratado sobre a arquitetura.

Também nesse período em Roma ele teria escrito I libri della famiglia, um livro enquadrado na produção dos moralistas e teóricos do século XV, responsáveis por uma grande mudança nos métodos educativos associada ao Humanismo ${ }^{55}$. Brandão ${ }^{56}$ destaca na pedagogia albertiana o incessante exercício contra o ócio e o triunfo da virtú sobre a fortuna.

Dos quatro livros que compõem I Libri della famiglia, Alberti afirma, em sua autobiografia, ter escrito os três primeiros antes de chegar a Florença, em 1434:

"Antes do ano trinta escreveu, e o fez na
lingua dos seus antepassados por amor a seus
parentes, de modo que pudesse ser lido por
eles, que desconheciam o latim, os seus
primeiro, segundo e terceiro livros Della
Famiglia em toscano. Concluiu-os em Roma, em

52 Segundo Grafton (2003, p.8), como abreviador apostólico, Alberti colocou sua habilidade de escrever a serviço dos maiores expoentes do alto clero. Além disso, o autor afirma que sua laurea em direito teria sido de grande importância para a obtenção desse cargo.

${ }^{53}$ Cf. Tavares $(2004, \mathrm{p} .15)$.

54 Benévolo (2002, p.94) cita outras três obras que ele teria escrito nesse período: o De Iunularum quadratura e o Ludi rerum mathematicarum, com questões matemáticas; e também o De punctis et lineis apud pictores, sobre pintura.

${ }_{55}$ Cf. Bensimon (1993, p.31).

56 Sobre os combates da virtu e da fortuna na obra de Alberti ver Brandão (2000) e Bianchi (1993). 
dezenove dias. Eles ainda eram, entretanto, brutos e inacabados, e não perfeitamente toscanos sob todos aspectos. De fato ele ainda não dominava a língua de seus antepassados, pois tinha crescido em terras estrangeiras durante o longo exilio dos Alberti. Era difícil escrever com elegância e finura em uma língua que somente naquele momento começava a usar com regularidade. contudo, rapidamente seus extremos esforços e sua dedicação permitiram-lhe atingir obter grande sucesso." "57

É nesse livro que Alberti aborda pela primeira vez o tema das vilas, destacando a importância de sua produção agrícola na economia familiar, tanto para a gestão econômica de grandes palácios como para o pequeno proprietário de terras:

"Esse é o primeiro ponto enfrentado por
Gianozzo, patriarca de uma familia
florentina, no diálogo de Leon Battista
Alberti sobre a administração familiar que
exprime alguma das tensões sociais
alimentadas pelos obstáculos encontrados
pela nova economia monetária nos confrontos
do sistema tradicional baseado na troca"58.

Sempre em busca da construção da virtu, ele cita Columella ${ }^{59}$, ao afirmar que as crianças criadas na vila, sob sol e esforço, são mais saudáveis e robustas que aquelas criadas no ócio, à sombra ${ }^{60}$. Também é apresentada no diálogo entre os personagens a recomendação de que a vila não seja muito distante da residência principal de seu proprietário, a fim de que ele possa receber os produtos das colheitas sem necessidade de grandes deslocamentos e também para que possa ir até lá a

\footnotetext{
57 FUBINI, R.; GALLORINI, A. M. L'autobiografia di Leon Battista Alberti: studio e edizione. In: Rinascimento. 2a.s., 12, 1972, pp.1-78, apud Grafton (2003, p.203), tradução da autora, do italiano: "Prima del trentesimo anno scrisse, e lo fece nella lingua dei suoi parenti, in modo che potesse essere letto da loro, che ignoravano il latino, i suoi primo, secondo e terzo libro Della Famiglia in toscano. Li fini a Roma, in diciannove giorni. Erano però grossolani e rozzi, e non perfettamente toscani sotto ogni aspetto. Egli non padroneggiava infatti la lingua dei suoi antenati, poiché era cresciuto in terre straniere durante il lungo esilio degli Alberti. Era difficile scrivere con eleganza e finezza in una lingua che stava solo allora iniziando ad adoperare con regolarità. In breve tempo, però, i suoi sforzi estremi e la sua operosità gli permisero di raggiungere un grande successo."

58 Ackerman (1992, p.91). Tradução da autora, do italiano: "Questo è il primo punto affrontato da Gianozzo, patriarca di una famiglia fiorentina, nel dialogo di Leon Battista Alberti sull'amministrazione familiare che esprime alcune delle tensioni sociali alimentate dagli ostacoli incontrati dalla nuova economia monetaria nei confronto del sistema tradizionale basato sul baratto." 59 Como aponta Visentini (1995, p.322), Columella é um proprietário de terras de origem espanhola contemporâneo de Sêneca, no século I. Para ele, ocupar-se da terra é um grande prazer, além de uma fonte de renda.

${ }^{60} \mathrm{Cf}$. Alberti (1994, p.51).
} 
fim de se exercitar. A presença constante do patrão também manteria os servos mais responsáveis e dedicados ao trabalho.

A relação da vila com o prazer, assim como a obtenção do prazer e da purificação por meio do trabalho também é discutida no texto, como pode-se ver no seguinte trecho da fala de Lionardo, um dos personagens dos diálogos:

"Qual homem seria aquele que não teria
prazer na vila? A vila proporciona lucros
enormes, corretos e certos (...). Enfim, é
assim: a vila se esforça para que em casa
não te falte nada, que em seu ânimo não haja
nenhuma melancolia, te encha de prazer e
lucros. E se a vila te dá algum trabalho,
não pretende como outros exercícios que ali
você seja triste, nem que se encha de
pensamentos, mas ela se agrada que seu
trabalho seja cheio de prazer". ${ }^{61}$

A vila nesse livro é descrita como um verdadeiro paraíso, onde é possível estar longe dos vícios e de todo tipo de maldade dos homens. Percebe-se uma aproximação do ideal clássico onde a vila era uma espécie de ilha de prazer e virtude, onde seu proprietário poderia se refugiar sempre que necessário. "Se os vícios habitam, como ocorre, entre os homens, a mim parece melhor criar os jovens na terra"62.

Também nesse livro Alberti fala das vilas encontradas em Florença, lugares agradáveis, com ar puro, belas paisagens, águas, bons ventos, mas que, apesar de todas essas características positivas, não deveriam nem ser mencionados, pois "são mais como palácios senhoriais, e tem mais a forma de castelos que de vilas."63

Escrever sobre Florença antes mesmo de chegar a essa cidade mostra que, mais que sobre as famílias florentinas, Alberti escrevia sobre sua própria familia. A famiglia Alberta é citada em diversas passagens do livro e a ela é dedicada a opção por escrevê-lo em vulgar, ao invés do latim empregado em quase todos textos albertianos, pois, ser lido pela própria família seria um prêmio para todo seu esforço ${ }^{64}$.

61 Cf. Alberti (1994, p.210-211).

62 C.f Alberti (1994, p.213).

63 Alberti (1994, p. 207). Tradução da autora, do italiano: "piú sono palagi da Signori, e piú tengono forma di castella che di ville."

${ }^{64}$ Cf. Alberti (1994, p.10). 
Após um período em Ferrara, Alberti voltou à província de Florença ${ }^{65}$, onde parecia ter alcançado o lugar que almejava ao afirmar que "o navio do estado navega melhor se alguém se dedica somente à reflexão, dizendo, àqueles que pedem conselhos, que coisa eles devem fazer." ${ }^{66}$ Para Grafton ${ }^{67}$, Alberti realmente era visto dessa forma

"A cultura de Leon Battista, sua coragem e
sua destreza em sociedade, que Ihe
permitiram fornecer seu parecer sobre muitos
argumentos sem parecer arrogante ou servil,
renderam-no um apreciado conselheiro nessas
cortes, um consultor erudito e dotado de
gosto impecável sobre questóes estéticas."

Florença era, nesse momento, o mais importante centro do Renascimento italiano e lá teve a oportunidade de acompanhar de perto os trabalhos dos artistas dos quais tinha se aproximado anteriormente e de tantos outros que veio a conhecer ${ }^{68}$, assim como de escrever dois tratados, o De pictura, sobre a pintura, e o De statua, sobre a escultura, ambas ainda consideradas artes manuais ${ }^{69}$. Esses dois tratados parecem ter finalidade divulgadora em relação à arte que se produzia em Florença e que, até aquele momento, era quase como se fosse um dialeto local ${ }^{70}$, pouco pronunciado ou conhecido fora dos limites da cidade. O fato de Alberti tê-los escrito em latim e prontamente traduzido para o vulgar ${ }^{71}$ demonstra a intenção de fazê-los atingirem públicos diversos,

"se a edição latina visava também a
predispor a recepça na corte de um novo
procedimento artístico cientificizante, a
edição vulgar italiana visava o público da

${ }^{65}$ Alberti havia recebido um cargo eclesiástico em San Martino a Gangalandi, que lhe proporcionou segurança econômica suficiente para que pudesse se voltar aos próprios interesses artísticos e humanísticos Cf. Frommel (2009, p.45).

${ }_{66}$ Cf. Thoenes (1998, p.70-72).

67 Cf. Grafton (2003, p.9). Tradução da autora, do italiano: "La cultura di Leon Battista, il suo coraggio e la sua destrezza in società, che gli permisero di fornire il suo parere su molti argomenti senza sembrare arrogante o servile, lo resero in queste corti un apprezzato consigliere, un consulente erudito e dotato di gusto impeccabile su questioni estetiche."

${ }_{68}^{6}$ Cf. Frommel (2009, p.45).

69 Benevolo (2002, p.94) aponta o De Pictura concluído em vulgar no dia 17 de julho de 1436 e em latim no dia 26 de setembro de 1436; já a data de conclusão do De Statua seria controversa, embora seja admitida como imediatamente anterior ao outro, pois no decorrer deste tratado Alberti se refere ao outro como um projeto futuro.

${ }^{70}$ Cf. Warnke (2001, p.77).

71 Algumas vezes são encontradas referências à tradução para o vulgar, que na verdade é apenas uma referência em oposição ao latim, que seria a língua dos intelectuais de formação humanista. Não se pode dizer que fosse italiano, já que o italiano como é conhecido hoje ainda não existia, as cidades da Itália nessa época possuíam, cada uma, seu dialeto local, de raiz latina. 
cidade, ao qual era sugerida a avaliação do artista que era corriqueira nas cortes: a edição vulgar era dedicada a Brunelleschi, que se via nesse momento, em 1434, envolvido num processo com a corporação dos construtores porque se recusava a pagar as taxas da corporação" ${ }^{72}$

Com o De Statua, Alberti teria fundado a noção de escultura enquanto ciência da representação tridimensional dos objetos no âmbito da representação projetiva, trabalhando com a proporção na passagem de uma escala a outra ${ }^{73}$. Já o De Pictura seria uma proposta para a sistematização dos preceitos da perspectiva central obtida a partir da planta, desenvolvidos por Brunelleschi, a quem, em julho de 1436, Alberti dedicou a versão em vulgar desse tratado. Nele o autor deixa claro seu ponto de vista - a geometria é o principal fundamento da pintura - mesmo sem afirmá-lo diretamente. Além de toda a discussão feita acerca dos métodos de trabalho do artista, o De Pictura teve um papel muito mais importante ao definir o lugar da pintura no novo sistema cultural, e avaliar objetivamente uma possível relação entre pintura e literatura. ${ }^{\mathbf{7 4}}$

"Na primeira parte apresenta a mais antiga
entre as descrições precisas relativas à
maneira de se criar um espaço prospéctico
sistemático e coerente em duas dimensões. o
resto do livro fornece uma descrição ainda
mais elaborada de qual deveria ser a
formação de um novo gênero de artista
culto."75

Esses dois textos foram fundamentados em argumentos propostos por autores clássicos e davam à pintura e à escultura um caráter intelectual e até mesmo erudito. Ao afirmar, por exemplo, que o valor primário da pintura está na emoção, Alberti parece fazer referência à retórica de Aristóteles, em que um bom discurso deveria ser capaz de mover emoções ${ }^{76}$. Da mesma forma, a aproximação de Alberti da arquitetura teria relação com o papel desempenhado pelos oradores de Cícero. ì época de Cícero, o orador era uma figura útil a serviço do bem

72 Cf. Warnke (2001, p.78). Já Grafton (2003, p.95) discorda, afirmando que não se tem provas concretas de qual das versões teria sido a original.

${ }^{73}$ Cf. Benevolo (2002, p.90).

74 Idem, p.94.

75 Cf. Grafton (2003, p.95), tradução da autora, do italiano: "Nella prima parte presenta la più antica tra le descrizioni precise relative al modo in cui creare uno spazio prospettico sistematico e coerente in due dimensioni. Il resto del libro fornisce una descrizione ancor più elaborata di quale dovesse essere il tirocinio di un nuovo genere di artista colto".

76 Idem, p.154. 
público, já no Renascimento Alberti repropõe esse papel por meio da arquitetura. Até mesmo o termo concinnitas ${ }^{\mathbf{7 7}}$, empregado frequentemente por Alberti para falar sobre harmonia e beleza, a partir da conformidade entre o todo e as partes, teria sido trazido da oratória ${ }^{78}$.

Para Panofsky ${ }^{79}$ a concinnitas albertiana pode ser chamada de conveniência ou conformidade, e pode ser percebida no modo como os arquitetos renascentistas tratavam a conclusão das obras góticas. Nesse momento, o estilo gótico já não era admitido, mas a não observação da concinnitas era ainda mais grave e, então, o autor apresenta as três soluções que seriam admitidas para esse problema. Na primeira opção, as partes préexistentes - e, portanto, góticas - eram remodeladas de acordo com os princípios renascentistas (como exemplo ele cita o Templo Malatestiano); na segunda, a obra poderia ser concluída com um estilo propositalmente semelhante ao gótico (o exemplo aqui são os desenhos de Bramante e Francesco di Giorgio para o Duomo de Milão); e na terceira, poderia ser buscado um meio termo entre as outras duas possibilidades (segundo o autor, o típico exemplo dessa solução é a fachada albertiana de Santa Maria Novella). Dessa forma, o emprego das formas góticas para completar estruturas pré-existentes não significa uma aceitação do estilo gótico, mas sim a adequação ao postulado da concinnitas.

Alberti repulsa quem não aceita a racionalidade da beleza, mas também não esclarece como obtê-la, em vez disso só afirma que existem princípios que governam as artes, razões que as caracterizam e os meios que as ampliam. Para Giontella, após afirmar que até mesmo para a natureza é difícil realizar uma obra bela, Alberti apresenta o emprego do ornamento como meio de completar essa forma ${ }^{80}$, como algo que pode ser acrescentado a

\footnotetext{
77 Sobre isso consultar Loewen (2007, p.29). A autora afirma que esse foi um dos muitos sinônimos empregados por Alberti para a beleza, que aparece de diversas formas, em diferentes contextos: pulchritudio, venustas, decoris, leporis, formosum, gratia, amoenitas, ornamentum e, por fim, concinnitas.

78 Loewen (2007, p.51) explica que, na arte oratória, concinnitas, compositio (composição) e numerus (ritmo) se referem à colocação das palavras.

79 Cf. Panofsky, E. Il significato nelle arti visive. Torino: Einaudi, 1962, p.188-192 apud De Fusco (2003, p.158). O autor também cita D.Hay, que em Profilo storico del Rinascimento italiano, também aborda o projeto de Alberti para o Templo Malatestiano, em Rimini, onde o interior teria sido restaurado no estilo gótico, mas no exterior foi composta uma espécie de máscara que o coloca de acordo com os parâmetros do novo estilo. Nesse sentido, então, até mesmo esse projeto que Panofsky classifica como uma adaptação do gótico ao estilo renascentista, aceita algo de gótico, chegando talvez a contrariar o princípio da concinnitas.

${ }^{80}$ Cf. Giontella (2010, p.213).
} 
essa forma no intuito de aperfeiçoá-la. Assim, o uso do ornamento seria uma forma de se aproximar a composição do conceito albertiano de beleza.

De acordo com Wittkower ${ }^{81}$, a principal característica da beleza albertiana é a ideia clássica de um sistema proporcional uniforme que governe todas as partes do edifício e a chave para a proporção correta é o sistema pitagórico da harmonia musical.

Ainda nessa passagem por Florença, por volta de 1440 Alberti teria escrito o "La Villa", um opúsculo dedicado à vida nas vilas, onde ele destaca seu papel não só como investimento, mas como lugar de refúgio e deleite: "Compre a vila para satisfação da sua família e não para deleite de outros"82.

A vila aqui descrita é mais voltada à produção rural que aquela do I Libri della Famiglia, onde a produção e o deleite pareciam ter peso igual. De fato, aqui como vila entende-se toda a propriedade rural, independentemente de nela existir ou não uma residência para o proprietário: "faz menos falta a casa às terras que as terras à casa" 83 .

Além disso, ele faz algumas observações, ainda que pouco objetivas, sobre como escolher a terra a ser comprada, destacando que a escolha deve ser ponderada sem pressa e levando em consideração os motivos que levaram o proprietário anterior a vendê-la. Segundo ele, é mais importante ter clima seja favorável que um solo pronto para o cultivo, pois o solo pode ser corrigido por meio da drenagem ou da adubação, mas não se pode interferir no céu ${ }^{84}$.

Alberti também ressalta a importância da produtividade da vila, a fim de que ela não seja somente uma casa longe do centro urbano. Não deve ser necessário comprar o que se pode produzir, mas pelo contrário, é interessante que se produza em abundância para que se possa vender os excessos: "Dotes a casa daquilo que precisas ou daquilo que podes vir a precisar. Não compres nenhuma das coisas que podes obter das tuas terras"85. A fim de obter maior produtividade ele dá conselhos acerca das atividades camponesas, relacionando-as com as fases da lua e a posição do sol, chegando a afirmar que "nada prejudica tanto

\footnotetext{
Cf. Wittkower (1952, p.37).

Cf. Alberti (2011b, p.2).

Cf. Alberti (2011b, p.2).

84 Cf. Alberti (2011b, p.3).

85 Cf. Alberti (2011b, p.3).
} 
toda a vila quanto não observar a cada dia onde o sol nasce e onde ele se põe" $e^{86}$.

O proprietário, para Alberti, tem o papel de gerenciar as atividades de todos os servos, para que servos e animais não fiquem desocupados: "aos servos e aos jumentos nunca darás ócio. Dizem que a fome e a necessidade vivem próximas do ócio" ${ }^{87}$.

Por fim, também nesse texto se verifica a busca da virtu, quando o autor louva o trabalho e o lucro obtido por meio da agricultura "Nenhuma virtude será maior que aquela livre de toda injustiça. Nada mais justo para enriquecer que a agricultura. E aquelas riquezas que se acumulam sem fraude são um bem divino" ${ }^{88}$.

No ano de 1447, Alberti volta a Roma, a convite do Papa Nicolau $V^{89}$ para "participar desde o princípio nas reflexões complexas sobre a restauração de São Pedro, que ameaçava ruína, assim como nos projectos de arranjo de toda a área do Vaticano"90, ou seja, tomar parte no plano de renovação arquitetônica e urbanística da cidade.

Especula-se que Alberti tenha participado do desenvolvimento de vários projetos nesse período ${ }^{91}$, ainda que, em muitos deles, não exista consenso sobre como tenha se dado essa participação. Alguns dos principais projetos a ele atribuídos são o Tempio Malatestiano, em Rimini, a fachada da Igreja de Santa Maria Novella e o Palazzo Rucellai, em Florença, e as Igrejas de Sant'Andrea e San Sebastiano, em Mântua.

Ao mesmo tempo em que desempenhava essa atividade como consultor da Santa Sé, Alberti escreveu o De Re Aedificatoria, seu tratado sobre a arte de construir que ainda hoje é uma importante referência no estudo da arquitetura do Renascimento italiano. Para elaborar esse tratado ele estudou as teorias arquitetônicas clássicas, confrontando-as com as ruínas de edifícios remanescentes desse período. Nessa sistematização do estudo dos edifícios antigos, Burns $^{\mathbf{9 2}}$ aponta uma contribuição

\footnotetext{
86 Cf. Alberti (2011b, p.8).

Cf. Alberti (2011b, p.3).

88 Cf. Alberti (2011b, p.8).

89 Tommaso Parentucelli de Sarzana (Nicolau V, pontificado 1447-1455) tinha sido seu colega de estudos e amigo.

90 Cf. Thoenes (2003, p.23).

91 Frommel cita o Portale Del Palazzo Vitelleeschi, em Tarquinia (1436-1439), 0 Palazzo Rucellai e também o Campanile da Catedral de Ferrara (1451-1454).

${ }_{92}$ Cf. Burns (1998, p.121).
} 
albertiana de notável importância, que é a leitura dos edifícios como se eles fossem verdadeiros textos instrutivos, podendo ser lidos da mesma forma que os humanistas estudavam as antigas obras literárias.

O De re Aedificatoria foi concluído em 1452, circulando em forma de manuscrito até que, em 1485, treze anos após a morte de Alberti, ele foi publicado pela primeira vez como livro impresso. "Alberti teria certamente aprovado esta iniciativa, sem que, contudo, a tivesse previsto: no seu manuscrito, ele pede aos copistas para transcreverem os números por extenso a fim de evitar erros."93 O tratado não se destinava apenas a um público especialista, mas também ao grande público de educação humanística e que conhecia o latim, visto que tinha sido publicado nesse idioma. A primeira edição em vulgar ocorreu somente em 1536 e em 1550, foi realizada a primeira edição ilustrada e traduzida em italiano, porém, segundo Thoenes" ${ }^{94}$ nesse momento "o texto já tem cem anos e já não oferece grande interesse."

Para escrever o De re Aedificatoria, Alberti demonstra ter consultado grande parte da literatura clássica a que teve acesso, sobre diversos temas. No decorrer do tratado, a cada menção a edifícios, materiais ou outros argumentos do gênero, são citadas diversas fontes antigas, ultrapassando um total de cinquenta referências ${ }^{95}$. Entre todas elas, entretanto, a única obra teórica que trata especificamente da arquitetura clássica é a de Vitruvio, que nem por isso se torna sua guia. Alberti assume uma postura crítica no confronto de Vitruvio, sobretudo no que diz respeito à sua redação.

Burns $^{96}$ aponta os principais pontos em que se percebe a referência a Vitruvio ao longo do De re Aedificatoria: a distinção entre edifícios públicos e privados; a tratativa acerca dos principais tipos de edifícios e das ordens; os problemas de proporcionalidade e a relação entre o todo e as partes; o clima, a salubridade e a orientação; o conceito de arquiteto profissional, adequadamente instruído; a arquitetura enquanto disciplina autônoma; e a tríade dos princípios fundamentais da arquitetura (firmitas, utilitas e venustas) a

\footnotetext{
3 Cf. Thoenes (2003, p.13).

4 Cf. Thoenes (2003, p.15).

95 Cf. Burns (1998, p.121).

96 Cf. Burns (1998, p.121).
} 
que soma seus próprios critérios de beleza: número (numerus), delimitação (finitio), disposição (collocatio) ${ }^{97}$.

Ao mesmo tempo em que são percebidas semelhanças entre os dois tratados, também existem várias diferenças. Alberti, como Vitruvio, escreve dez livros, mas eles são subdivididos em duas partes: os primeiros cinco dedicados exclusivamente aos problemas materiais da construção do edifício, e os demais enfocando o ornamento, ou seja, 'as formas de um ponto de vista estético ${ }^{\prime 98}$.

Ao longo de todo o De re Aedificatoria, Alberti faz um elogio à superioridade da concepção em relação à execução na arquitetura, aproximando-a do ideal vitruviano de arte liberal ${ }^{99}$. O arquiteto aparece como alguém que deve dominar completamente as disciplinas mais altas ${ }^{100}$, em consonância com Vitruvio, que propunha a ciência do arquiteto "ornada de muitas disciplinas e de vários saberes"101. Ele destaca a separação entre a concepção e a execução manual da obra afirmando que "a mão do carpinteiro serve somente de instrumento ao arquiteto" ${ }^{102}$.

O tratado de Alberti é dividido em dez livros: I - 0 delineamento dos edifícios ${ }^{103}$; II - Os materiais; III - A construção; IV - Edifícios para fins universais; V - Edifícios para fins particulares; VI - O ornamento; VII - O ornamento de edifícios sagrados; VIII - O ornamento de edifícios públicos profanos; IX - O ornamento de edifícios privados; X - O restauro das obras.

Em todo o tratado percebe-se um grande cuidado com as terminologias e os exemplos empregados. Alberti era um

97 Cf. Di Teodoro (2002).

98 Cf. Thoenes (1998, p.126).

99 Cf. Schlosser, J. La letteratura artistica. La nuova Italia: Firenze, 1956, p.122. apud De Fusco (2003, p.116).

100 Percebe-se aqui uma referência à hierarquia das artes existente nesse momento e já referida nos capítulos anteriores.

${ }_{101}$ Cf. Pollio (2007, p.61).

102 Cf. Alberti (2010, p.6), tradução nossa do original em italiano: "la mano del carpentiere serve solo da strumento all'Architettore".

103 O termo latino é lineamenta, traduzido por delineamento na edição portuguesa do tratado, publicada pela primeira vez em 2011. Na edição brasileira, de 2012, foi empregada a palavra desenho que, entretanto, não abarca a gama de procedimentos a que Alberti se refere nesse livro. Para ele os desenhos são "o traço constitutivo da forma, as linhas essenciais da idéia (...) eles não representam só a primeira etapa do projeto, mas a sua lógica". O mesmo acontece na edição italiana, de 2010. Nela, Giontella (2010, p.11) explica que, ao traduzir o texto do latim, a melhor significação para 'lineamenta' foi encontrada no termo 'Iineamenti' e não no termo 'disegno'. Segundo a autora, "Iineamenti" estaria mais próximo de corresponder à lógica albertiana e à estrutura da obra. 
humanista no modelo renascentista e, como tal, era versado em todas as disciplinas do trivium e do quadrivium, característica que fica evidente ao longo da exposição de suas ideias no De re Aedificatoria e no fato de possuir uma obra escrita que aborda quase todos os grandes temas da época ${ }^{104}$.

Apesar disso, não se pode deixar de notar que Alberti se propõe a fazer um discurso sistematizado e organizado, mas que suas ideias se misturam no decorrer do texto. Ao invés de um raciocínio linear, como parecia desejar na emulação de Vitruvio, ele constrói uma espécie de teia, em que os conceitos se interpenetram e, algumas vezes, até se contradizem, em função dos argumentos a que se relacionam nos diferentes trechos.

Independentemente disso, seu tratado apresenta contribuições muito significativas no estudo da arquitetura do início do Renascimento. "Os artistas do início do Quattrocento, cujas ideias ele exprime, eram inteiramente absortos pela exploração do universo visível que haviam recentemente descoberto. Precisavam de conselhos práticos, e não de especulações abstratas: e isso é exatamente o que Alberti lhes deu. "105

\section{Florença e as primeiras vilas Médici}

Florença foi modelo da formação de uma cidade-estado e da economia capitalista para todo o resto da Europa. Ela também foi bastante representativa da transformação ocorrida no campo, que deixou de ser zona de terras e fortalezas feudais, passando uma área mais valorizada que atraía investimentos e onde se multiplicavam as vilas ${ }^{106}$.

As vilas produzidas nesse período não resistiram ao passar do tempo, mas aparecem documentadas em pinturas e textos produzidos na época, como o Decameron de Giovanni Boccaccio. Por volta de 1350, Giovanni Villani, em sua Cronica ${ }^{107}$, também

\footnotetext{
104 Cf. Thoenes (1998, p.24).

105 Cf. Blunt, A. Le teoria artistiche, op cit, p.32-35, apud De Fusco (2003, p.186), tradução nossa, do italiano: "Gli artisti dell'inizio del Quattrocento, le cui idee egli esprime, erano interamente assorbiti dall'esplorazione dell'universo visibile che avevano da poco scoperto. Avevano bisogno di consigli pratici, non di speculazioni astratte: e questo è esattamente ciò che l'Alberti diede loro."

106 Cf. Ackerman (1992, p.84).

107 Villani, G. Cronica. Livro XI, cap. XCIV, Firenze 1847, III, p.326, e G. Gobbi, La villa fiorentina. Elementi storici e critici per una lettura, Firenze 1980, p.19. Apud Visentini (1995, p.41). Tradução nossa do original em italiano: "non $V^{\prime}$ era cittadino popolano o grande che non avesse edificato o che
} 
registrou as mudanças que ocorriam: "não havia cidadão pobre ou rico que não tivesse edificado ou que não edificasse no campo grandes propriedades, e habitações muito ricas, e com belos edifícios, e muito melhor que na cidade".

Nesse momento, Florença estava imersa em um intenso revival da antiguidade romana em todas as formas das artes, ciências e letras. Na construção civil, diferentemente do que acontecia em outras cidades italianas, cada palácio ou capela encomendada por ricos florentinos deveria excluir referências medievais e empregar somente a tipologia recuperada de antigos edifícios romanos ${ }^{108}$.

No campo, entretanto, ocorria situação oposta. As vilas antigas ressurgiram em formas medievais, talvez porque nesse momento ainda houvesse necessidade de defesa, já que os campos nessa época ainda não eram áreas protegidas e seguras como o interior das cidades fortificadas ${ }^{109}$.

A evolução formal das vilas desde essas primeiras construções fortificadas até Villa Madama, que foi o primeiro ponto alto na modernização dessa tipologia, ocorreu sob o comando de quatro gerações de Médici ${ }^{110}$.

As duas vilas Médici mais antigas, Villa Trebbio (Figura 8) e Villa Cafaggiolo (Figura 9) são atribuídas a Michelozzo por Giorgio Vasari ${ }^{111}$. Ambas encomendadas por Cosimo de' Medici, as duas vilas estavam localizadas em propriedades próximas da estrada que levava de Florença em direção ao norte, e serviam principalmente como centros de recebimento e distribuição da produção agrícola das propriedades que a família possuía na região ${ }^{112}$.

Embora nesse momento as vilas ainda não fossem vistas como símbolo de poder e prestígio, Villa Trebbio e Villa Cafaggiolo já assumiam as funções antigas de relaxamento e prazer, mas formalmente ainda se aproximavam das fortalezas medievais, o que pouco depois se repetiu na Villa Careggi, também encomendada por Cosimo.

"Os Médici, particularmente, devem ter sentido a necessidade de um retiro protegido

non edificasse in contado grande e ricca possessione, e abitura molto ricca, e con belli edificii, e molto meglio che in città".

108 Cf. Ackerman (1992, p.84).

109 Cf. Ackerman (1992, p.85).

110 Cf. Frommel (2009, p.12).

111 Cf. Vasari (1986, 348).

112 Cf. Ackerman (1992, p.86-88). 
onde se abrigar em caso de oposição violenta ao seu poder. Provavelmente foi essa a exigência que, nos anos seguintes ao exílio de 1433, levou-os a preferir arquiteturas fortificadas. "113

Alberti não aceitava a ambiguidade das vilas-castelo construídas por Cosimo e, provavelmente, suas críticas às vilas modernas com formas medievais eram dirigidas a ele $e^{114}$. Em seu De re Aedificatoria, ele criticou duramente o emprego de formas medievais, especialmente ameias, em residências, associando-as à tirania:

"Não merecem a minha aprovação aqueles que
encimaram as residências de cidadãos
privados com sacadas e ameias; esses
elementos são próprios de uma fortaleza ou
antes dos tiranos da cidade, e estranhos a
cidadãos pacíicos e a uma sociedade bem
ordenada, uma vez que significam ou medo
incutido ou agravo planeado."115

A primeira vila Médici construída sem a aparência fortificada foi a Villa Fiesole, encomendada por Giovanni de' Médici, filho de Cosimo, por volta de 1455. Ainda que Vasari também atribua Villa Fiesole a Michelozzo, atualmente há autores que defendem que ela tenha sido inspirada, senão projetada, por Alberti, pois apresenta grande afinidade com suas ideias ${ }^{116}$ tanto na forma quanto na função.

Situada no alto de uma colina de onde se avistava quase toda Florença, essa vila era destinada exclusivamente à realização de pequenas reuniões e breves estadas ao longo do ano, priorizando o otium ${ }^{117}$, ao contrário do que ocorria em suas antecessoras de finalidade agrícola.

\footnotetext{
113 Ackerman (1992, p.90). Tradução da autora, do italiano: "I Medici, in particolare, dovettero sentir ela necessità di un ritiro protetto nel quale riparare in caso di opposizioni violente al loro potere. Probabilmente fu questa l'esigenza che, negli anni seguenti l'esilio del 1433, li portò a preferire architetture fortificate."

114 Ackerman (1992, p.114) e Alberti (1994, p.207).

115 Alberti, Livro IX, Capítulo 4 (2011, p.590).

116 Cf. Burns (2012, p.42), Frommel (2010, p.12). Ackerman (1992, p.99) acrescenta que, ainda que tenha sido publicado somente em 1485, o De re Aedificatoria foi concluído contemporaneamente à execução da Villa fiesole.

117 Cf. Frommel (2009, p.12).
} 


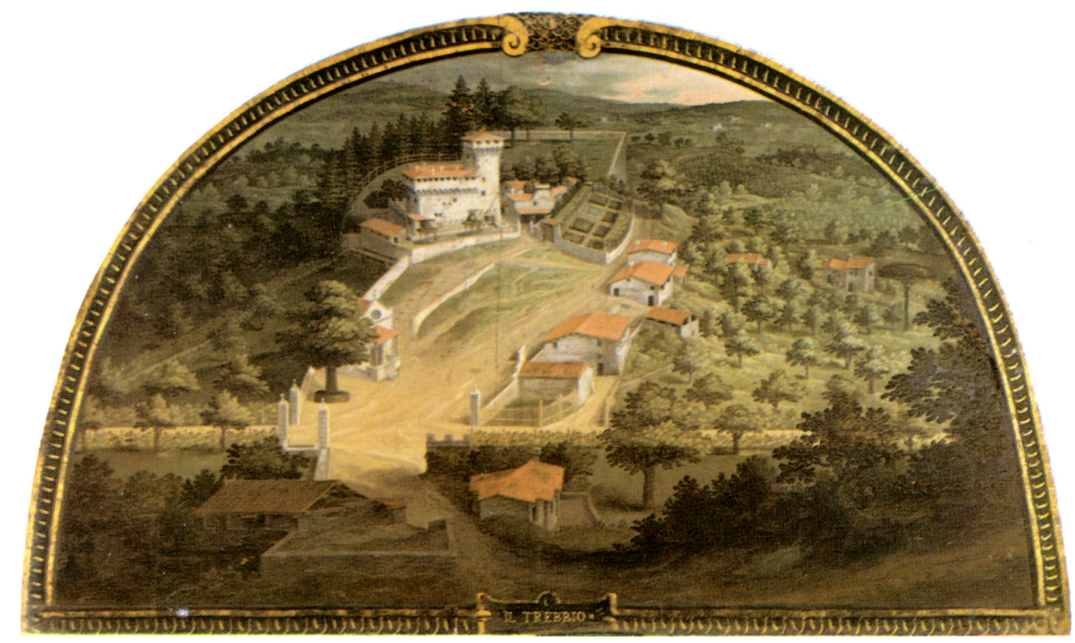

Figura 8 - Representação da Villa Medici Trebbio, por Giusto Utens. Fonte: Trebbio utens. Con licenza Public domain tramite Wikimedia Commons (sup.). 


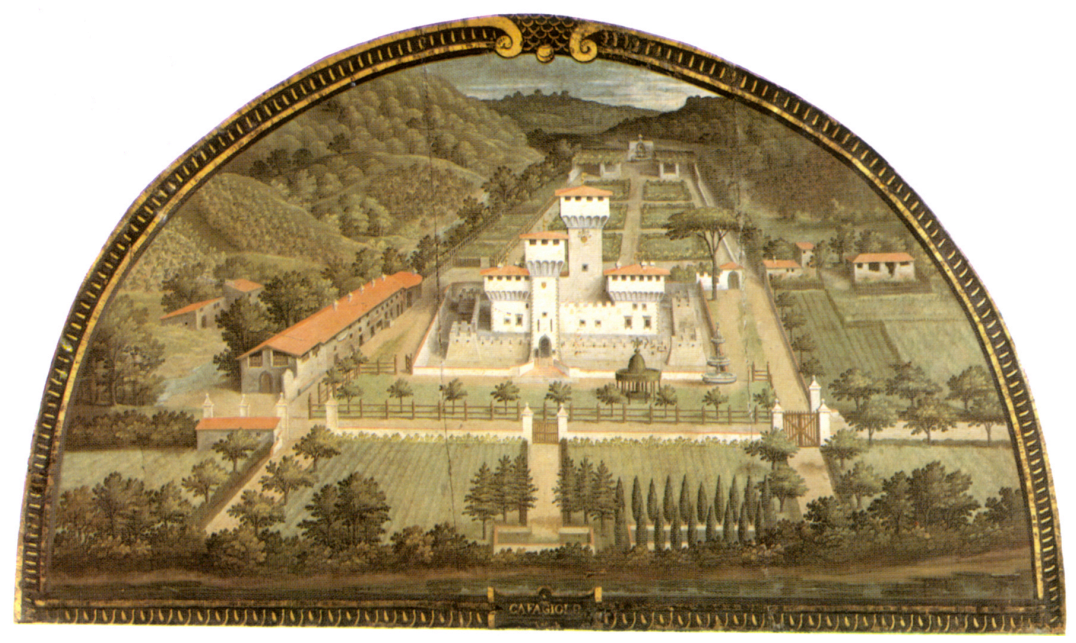

Figura 9 - Representação da Villa Medici Cafaggiolo, por Giusto Utens (inf.). Fonte: B Con licenza Public domain tramite Wikimedia Commons ( $\sup$. 
Essa é a primeira vila Médici voltada para o exterior, sem a presença de pátio central. Ao invés disso, ela possui estrutura cúbica rebocada e pintada de branco, com loggie fechadas por arcadas tanto na fachada frontal quanto na traseira. Percebe-se nessa vila o esforço para torná-la paradigma do estilo arquitetônico mais atual ${ }^{118}$, além de ser símbolo de poder mantendo domínio visual sobre a cidade, mesmo estando fora de seus limites.

Outra paradigmática vila Médici foi a Villa Poggio a Caiano, que de acordo com Vasari foi projetada em conjunto por Lorenzo de' Médici e Giuliano da Sangallo, em 1485. Ao contrário de Cosimo, Lorenzo teve um papel mais ativo na modernização da arquitetura recusando a tipologia das vilascastelo e não se limitando a comitente, mas assumindo a coautoria do projeto:

"Poggio a Caiano completava a formação de
Lorenzo como perfeito homem de vila, na
prática o principal fundador da cultura e da
arquitetura de vila do século XVI:
apaixonado por agricultura, cantor da vida
no campo, promotor da publicaço do tratado
de arquitetura de Alberti, (co)projetista e
construtor de vilas"

Situada em uma grande propriedade rural próxima a Florença, assim como Villa fiesole ela era composta por uma estrutura cúbica pintada de branco e estava implantada no alto de uma colina, de onde podia tanto admirar a cidade quanto, a partir dela, ser admirada (Figura 10).

Também nessa vila pode-se perceber a afinidade do edifício com os preceitos albertianos. Na fachada principal, um frontão destaca a entrada e, ainda que Alberti recomende que ele não seja feito "de modo a aspirar à imponência do templo"120, ele traz para os edifícios residenciais uma magnificência que até então estava reservada aos edifícios religiosos ${ }^{121}$.

\footnotetext{
118 Cf. Ackerman (1992, p.96).

119 Burns (2012, p.43). Tradução da autora, do italiano: "Poggio a Caiano completava la formazione di Lorenzo come perfetto uomo di villa, in pratica il principale fondatore della cultura e dell'architettura di villa del XVI secolo: appassionato d'agricoltura, cantore della vita di campagna, promotore della pubblicazione del trattato d'architettura di Alberti, (co)proggettista e costrutore di ville."

${ }_{120}$ Alberti, Livro IX, Capítulo 4 (2011, p.590).

121 Cf. Ackerman (1992, p.104).
} 


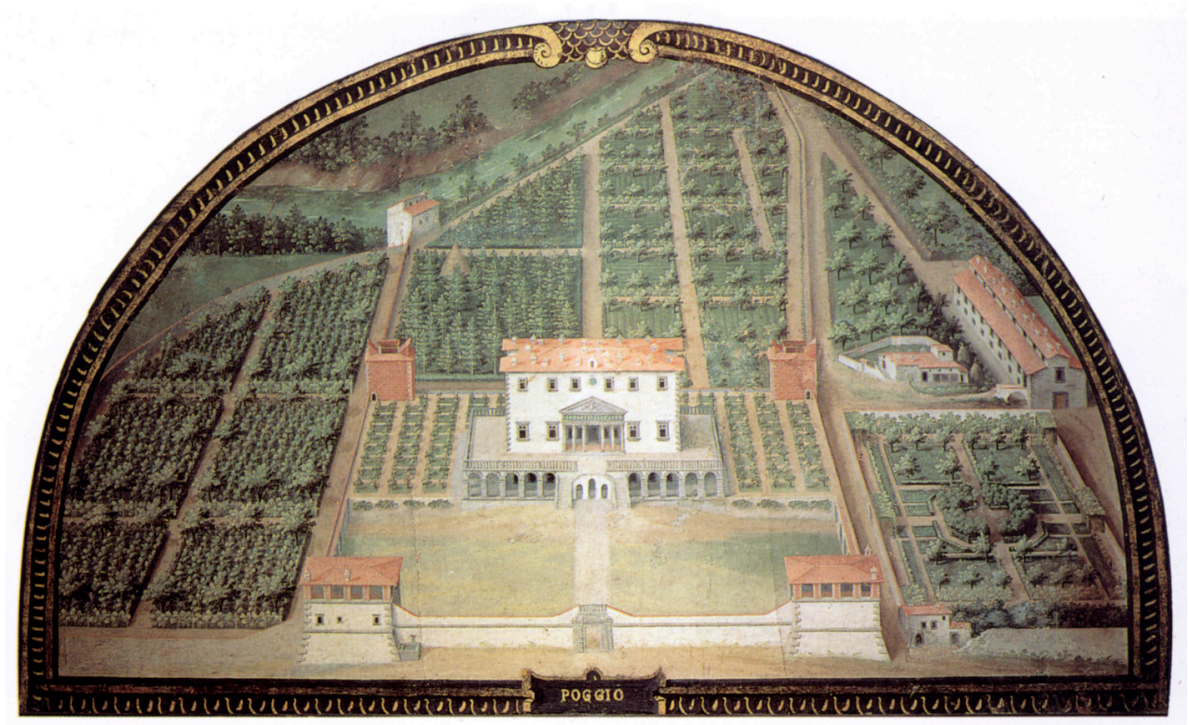

Figura 10 - Villa Poggio a Caiano, representação de Giusto Utens, 1599-1602. Fonte: Con licenza Public domain tramite Wikimedia Commons ( $\operatorname{sup.}$ ) 
o edifício apresenta uma hierarquia de setores verticalizada, com o setor de serviços situado no nível do terreno e do jardim. Para chegar ao pavimento principal o percurso é quase cerimonial, começando pelas duas escadas curvas, passando pela loggia que serve de vestíbulo e também pelo átrio que leva ao salão central. Em torno desse salão se organizam quatro apartamentos. Ainda que o exterior do edifício não seja ornamentado, ele se assemelha mais à casa de um príncipe ou a um palácio do que a um casa de campo ${ }^{122}$.

A disposição planimétrica determinada pelos eixos e pela proporção entre os ambientes também reflete a influência albertiana sobre a nova arquitetura Toscana. O salão central tem pé direito duplo, ocupando toda altura dos dois pavimentos e assumindo o caráter de coração da casa, com os demais ambientes agrupados em torno a ele, como preconizava Alberti.

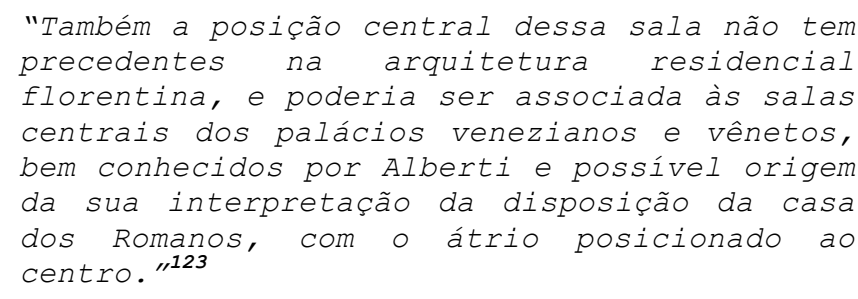

Outra vila projetada por Lorenzo de' Médici e Giuliano da Sangallo foi bastante inovadora e também influenciou grande parte das vilas produzidas nos séculos XVI e XVII, a Villa di Agnano. Concluída somente após a morte de Lorenzo, essa vila estava em uma grande propriedade rural próxima a Pisa e conjugava as funções agrícolas e de deleite.

Essa vila foi concebida com todas as estruturas dispostas ao longo de um eixo de simetria no terreno com um leve declive: as estruturas agrícolas atrás da casa e os jardins e tanques de peixes logo abaixo dela ${ }^{124}$.

Assim como em Poggio a Caiano, aqui o piano nobile também é elevado em relação ao nível do jardim externo, onde estava o piso destinado ao setor de serviços. Uma escada dupla leva o visitante até o piano nobile, mas não há loggia ou frontão, a

\footnotetext{
122 Cf. Frommel (2009, p.12).

123 Burns (2012, p.45). Tradução da autora, do italiano: "Anche la collocazione centrale di questa sala non ha precedenti nell'architettura residenziale fiorentina, e ricorda semmai le sale dei palazzi veneziani e veneti, ben noti da Alberti e possibile origine della sua interpretazione della disposizione della casa dei Romani, con l'atrio posizionato al centro."

${ }^{124}$ Cf. Burns (2012, p.46).
} 
entrada do vestíbulo é marcada por uma serliana. Um corredor estreito faz o papel de átrio e leva ao salão principal, como posteriormente é retomado em Villa Madama. Essa é a primeira vila com um piano nobile único, como se via nas casas antigas elogiadas por Alberti ${ }^{125}$.

\section{A difusão das vilas}

Com a difusão da aspiração ao viver à antiga, a construção civil se tornava um campo fértil para uma produção nova e significativa. Na falta de exemplos concretos utilizáveis da antiguidade e muitas vezes com a interpretação das difíceis indicações de Vitruvio, surgiam novas tipologias de habitação aptas a satisfazer as exigências de uma vasta gama de usuários que ia desde a alta corte a modestos artesãos e camponeses, passando pela rica nobreza, pela aristocracia religiosa e também por integrantes da burguesia de diversas faixas de renda ${ }^{126}$.

Os projetos de Lorenzo de' Medici e Giuliano da Sangallo tiveram grande repercussão e influenciaram muitas outras vilas posteriores. Em 1487 foram retomadas no sul da Itália várias características das vilas de Poggio a Caiano e Agnano na Villa di Poggioreale, um projeto realizado para o espanhol Ferrante de Aragão, rei de Napoli nesse momento da dominação espanhola no sul da Itália ${ }^{127}$.

Ainda que não haja consenso quanto à autoria do projeto, ele provavelmente foi concebido por Lorenzo de' Medici e Giuliano da Sangallo, e certamente executado por Giuliano da Maiano, que no decorrer dos trabalhos pode ter promovido alterações no projeto original ${ }^{128}$. Mesmo sendo posterior a Villa Poggio a Caiano e Villa Agnano, formalmente a Villa di Poggioreale era muito semelhante a um castelo, como as primeiras vilas Médici.

No centro do edifício, o salão central dá lugar a um cavaedium, que era um grande cortile rodeado por colunatas e degraus compondo um auditorium destinado a festas e espetáculos, ambiente que Alberti havia apontado como indispensável para as casas dos príncipes ${ }^{129}$ (Figura 11).

\footnotetext{
25 Cf. Frommel (2009, p.13).

126 Cf. Bruschi (2002, p.13).

127 Cf. Zecchino (2002, p.2).

128 Cf. Burns (2012, p.49); Frommel (2010, p.12).

129 Cf. Frommel (2009, p.12).
} 
Nessa vila os apartamentos se situavam em seus quatro ângulos, interligados por loggie, e sobre cada apartamento havia uma torre defensiva. A distribuição nesse edifício influenciou diversos projetos posteriores, como a Villa Soranza, de Michelle Sanmicheli, e também a Villa Mocenigo sul Brenta, de Andrea Palladio.

Da mesma forma, a partir de Villa Fiesole e Villa Poggio a Caiano a loggia ganhou importância, chegando a ser utilizada como elemento central da Villa Belvedere, encomendada pelo Papa Innocenzo VIII, e também na Villa Farnesina, de Agostino Chigi.

Na Villa Farnesina a loggia desempenha um papel ainda mais importante, funcionando como elemento articulador dos espaços e, portanto, assumindo o caráter albertiano de coração do edifício.

Após a morte de Lorenzo de' Medici, ocorrida em 1492, Giuliano da Sangallo se tornou arquiteto pessoal do cardeal Giuliano della Rovere, um dos maiores comitentes da época e que, em 1503 ele se tornou o papa Júlio II.

Decidido a modernizar a residência papal e dar a ela um caráter imperial, Júlio II encomendou o projeto do Cortile del Belvedere (Figura 11) a Bramante e nomeou Giuliano da Sangallo segundo arquiteto ${ }^{130}$.

Como o próprio nome sugere, o cortile não é uma vila, em sua inauguração foi apresentado como uma rua de ligação entre o Palazzo Vaticano e a Villa Belvedere, mas apesar disso ele retoma aspectos das mais suntuosas vilas da antiguidade em seus amplos espaços abertos. O projeto apresentado se desenvolve simetricamente em torno de um eixo central, com princípios da composição prospéctica, realçando seu efeito cenográfico ${ }^{131}$. Dois corredores ligam os edifícios, dividindo 0 vasto terreno ascendente em três níveis ${ }^{132}$ e tratando da mesma forma a arquitetura e a paisagem ${ }^{133}$.

130 Cf. Frommel (2009, p.13).

131 Cf. Burns (2012, p.52).

132 Cf. Frommel (2009, p.13).

133 Cf. Barbosa (2005, p.72). 

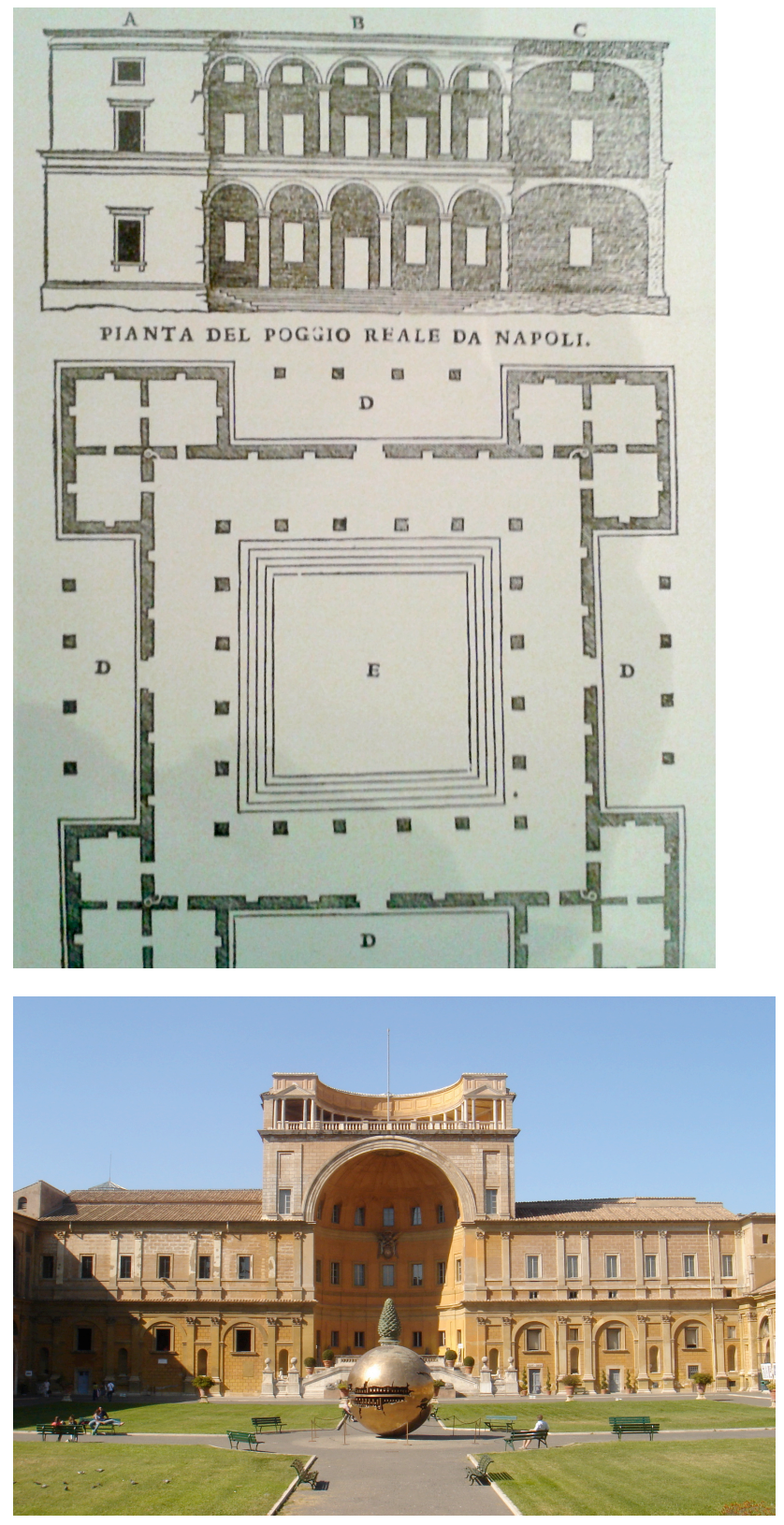

Figura 11 - Planta da Villa di Poggioreale publicada no tratado de Serlio ${ }^{134}$. Fonte: Beltramini; Burns (2010, p.231). Figura 12 - Cortile del Belvedere. Fonte: Burns (2012, p.135).

\footnotetext{
134 Ainda que Serlio não tenha conhecido a Villa di Poggioreale pessoalmente, conheceu os desenhos que Baldassare Peruzzi fez da vila após visitá-la e publicou-os em seu tratado, aumentando seu alcance. (Burns, 2012, p.51).
} 
Com a morte de Julio II, em 1513, o filho de Lorenzo Medici, Giovanni, foi eleito papa, adotando o nome de Leão X. Ele foi o comitente e encarregou Raffaello Sanzio do projeto de uma das mais significativas vilas do século XVI, a Villa Madama. "Situada sobre a ponte Milvio, a vila deve se tornar símbolo da magnificência dos Médici para acolher os visitantes antes que cheguem ao Vaticano."135

Foram elaboradas várias versões diferentes do projeto até que, em 1518, a construção da vila começou. É curiosa a relação que se percebe entre a descrição que Rafaello faz de Villa Madama, em uma carta a Baldassare Castiglione, e as descrições que Plinio o Jovem fez de suas vilas. A afinidade entre as cartas pode ser percebida tanto nas expressões utilizadas, quanto no enfoque à orientação e às experiências e sensações propiciadas pelo edifício ${ }^{136}$.

Assim como acontecia em vilas antigas e foi retomado nas vilas Médici nos arredores de Florença, Villa Madama foi implantada na encosta de uma colina. A zona de serviços é colocada no pavimento inferior. Rafaello pretendia liberar a fachada de elementos defensivos, criando uma loggia com sacada de onde o papa pudesse saudar e abençoar os hóspedes. Também retomava elementos do Cortile del Belvedere, como uma sequência de jardins em diferentes cotas, a fim de superar o desnível de $26 \mathrm{~m}$ entre as extremidades do terreno.

O edifício foi concebido como uma grande vila romana, e não somente com formas recuperadas da antiguidade, um processo que posteriormente se repete na obra de Palladio. Embora o projeto de Rafaello não tenha sido concluído, ele se tornou conhecido a partir de sua publicação no tratado de Serlio.

Nessa época era usual que os edifícios novos fossem logo visitados e comentados ${ }^{137}$, e Serlio, além das antiguidades romanas, incluiu em seu tratado edifícios modernos de grande importância. Além da Villa Madama, ele representou os romanos Cortile del Belvedere, Tempietto de Bramante, o projeto da Basilica di San Pietro e também a Villa di Poggioreale, em Napoli.

\footnotetext{
135 Frommel (2009, p.18). Tradução da autora, do italiano: "Situata immediatamente sopra il ponte Milvio, la villa deve diventare simbolo della magnificenza madicea per accogliere i visitatori prima che giungano in Vaticano."

136 Burns (2012, p.53); Ackerman (1992, p.28).

137 Cf. Burns (2012, p.36).
} 
No final do século XV, com o crescimento demográfico e a necessidade de autonomia na produção de gêneros alimentícios por grande parte dos estados, frente aos preços inflacionados, a agricultura se tornou um investimento atraente e encorajou grandes projetos de beneficiamento e irrigação, além de melhorias em estradas e cursos d'água navegáveis e da renovação de pontes ${ }^{138}$.

Nos primeiros anos do século XVI a organização do território já tinha sido amplamente alterada, muitas cidades assumiam um caráter mais renascentista, com a regularização e a modificação dos antigos traçados de suas ruas e também a renovação da edilícia civil. No campo, além de todas as mudanças relacionadas à infraestrutura, os velhos castelos também se transformavam e se tornavam grandes residências nobiliárias mais próximas da ideia de vilas extra-urbanas que de fortalezas ${ }^{139}$.

Edificar nas áreas rurais já passava a ser mais seguro, ainda que não fosse conveniente expor as residências em campo aberto, como, cerca de cinquenta anos mais tarde, Palladio fez nas vilas Emo e Barbaro ${ }^{140}$.

Essa mudança também era percebida na localização das propriedades rurais, que se afastavam das regiões já tradicionalmente destinadas a essa finalidade e iam em direção a áreas desabitadas, onde era possível estabelecer grandes áreas de terras. Além disso, passou-se a reunir em um único complexo a residência patronal e os edifícios destinados ao desenvolvimento das atividades e serviços, da mesma forma como era descrito nos textos clássicos de Catão, varrão e Virgílio ${ }^{141}$.

\section{As vilas vênetas}

As vilas discutidas até aqui estavam associadas à ideologia de vida na vila, concebidas com foco no otium e podendo ou não ser produtivas, afinal, eram mantidas com os recursos excedentes das atividades citadinas de proprietários de origem nobre, como duques, príncipes, papas e importantes cardeais ${ }^{142}$.

\footnotetext{
38 Cf. Burns (2012, p.7).

139 Cf. Bruschi (2002, p.12).

140 Cf. Ackerman (1996, p.22).

141 Cf. Ackerman (1996, p.27).

142 Cf. Visentini (1995, p.221).
} 
Desde a arquitetura produzida no início do Renascimento até as primeiras criações de Palladio, cerca de cem anos se passaram e, nesse período, foram feitas muitas experimentações baseadas nos exemplos preexistentes que eram os castelos, as residências urbanas e rurais ${ }^{143}$. Também nesse período a organização territorial foi bastante modificada.

\begin{abstract}
"Das primeiras vilas-fortalezas dos Médici às vilas-templo dos venezianos, certamente há uma evolução que testemunha a relação com - território. Passa-se da ocupação pontual àquela reticular, em outras palavras, da presença como controle à presença como exploração do solo. Na terra firme veneziana, a vila é muito mais que uma ilha graciosa onde se vai para discutir sobre filosofia e belas artes; é um instrumento de planejamento territorial."
\end{abstract}

A República de Veneza, que tinha sua afirmação política e seu poder econômico vinculados ao domínio exercido no comércio com o Mediterrâneo Oriental, até o final do século XIV era toda voltada para o mar e não tinha se deparado com a necessidade de estabelecer um verdadeiro território ${ }^{145}$. Com a crise que enfrentou após a tomada de Constantinopla pelos turcos e a grande inflação que se seguiu ao afluxo de metais preciosos vindos da América, os venezianos se voltaram cada vez mais para o interior do território.

Mais que a expressão de um ideal de vida, nesse momento a presença nos campos tinha uma importante função política e também econômica, como se deduz "das dimensões, da importância e da proximidade dos anexos destinados a usos agrícolas, como aquelas longas arcadas - no Vêneto «barchesse» - que mais tarde Palladio ainda viria a integrar ao corpo do edifício"146.

Já nas primeiras décadas do século XVI, a agricultura se tornou a base da economia da República de Veneza e a vila passou a ser a expressão arquitetônica das relações entre a

\footnotetext{
143 Cf. Ackerman (1996, p.22).

144 Corboz (1995, p.9). Tradução nossa, do original em italiano:

145 Segundo Visentini (1995, p.221), ela se limitava ao controle da laguna com suas ilhas e algumas bases ao longo do mar Adriático, até o estreito de Bósforo e a extremidade oriental do Mar Negro.

146 Ackerman (1996, p.24). Tradução da autora, do italiano: "dalle dimensioni, dall'importanza e dalla prossimità degli annessi destinati a usi agricoli, come quei lunghi porticati - in veneto «barchesse» - che piú tardi Palladio avrebbe addiritura integrato com corpo di fabbrica principale."
} 
estrutura social e fundiária local ${ }^{147}$, além de assumir outros papéis, como foi apontado por Burns ${ }^{148}$ :

\begin{abstract}
"O clima político e religioso que se instituiu na Itália no meio do século XVI encorajou a ideia do campo como lugar de retiro, onde gozar da própria independência, onde era possível escapar à vigilância dos vizinhos, dos informantes do governo (como em Florença) ou da Inquisição e onde, por exemplo, [seria possível] organizar na vila encontros secretos de caráter religioso que na cidade teriam sido perigosos demais".
\end{abstract}

Graças a esses investimentos agrícolas e também aos investimentos industriais, a aristocracia vêneta foi capaz de resistir por algum tempo à pressão econômica dos novos impérios monárquicos da Europa ocidental"149. "A afirmação da dominação espanhola na Itália e a virtual ausência da França na política internacional durante as guerras religiosas reduziram a utilização da Itália como um campo de batalha internacional, encorajando investimentos no campo"150.

Devido ao saque de Roma, na década de 1520, vários artistas talentosos que atuavam em Roma chegaram ao Vêneto em um intervalo de poucos anos. Entre eles pode-se destacar Giovanni Maria Falconetto (1468-1535), Giulio Romano (14991546), Michele Sanmicheli (1487/88-1559), Jacopo Sansovino (1486-1570) e Sebastiano Serlio (1475-1554?), que foram os principais responsáveis por uma mudança drástica na arquitetura produzida na região ${ }^{151}$.

No período que foi de 1530 a 1560 muitos proprietários de terras vênetos transferiram sua residência principal para suas propriedades agrícolas, gerando uma demanda por edifícios modernos, já que os castelos que existiam até então não eram

\footnotetext{
147 Cf. Visentini (1995, p.221).

148 Burns (2012, p.34). Tradução da autora, do italiano: "Il clima politico e religioso che si instaurò in Italia nei decenni centrali del XVI secolo non fece che incoraggiare l'idea della campagna come luogo di ritiro in cui godere della propria indipendenza, dove era possibile sfuggire alla sorveglianza dei vicini, degli informatori governativi (come a Firenze) o dell'Inquisizione e dove, ad esempio, organizzare in villa incontri segreti a carattere religioso che in città sarebbe stato troppo pericolosi."

149 Cf. Ackerman (1996, p.25).

150 Burns (2012, p35). Tradução da autora, do italiano: "L'affermarsi della dominazione spagnola in Italia e la virtuale assenza della Francia dalla politica internazionale durante le guerre di religione ridussero l'utilizzo dell'Italia come campo di battaglia internazionale, incoraggiando investimenti in campagna."

${ }^{151}$ Cf. Battilotti (2011, p.9-10).
} 
adequados para abrigar proprietários, seus hóspedes, empregados e animais ${ }^{152}$.

"Para projetá-los era necessário um
arquiteto que, atingindo a maturidade nos
anos 1530, sobrevivesse até a recessão
edilícia causada pelo período de deflaço em
torno a 1570; que tivesse a capacidade -
incomum no Renascimento, por falta de uma
tradiça pró-constituida - de projetar
edifícios funcionais, mas que dominasse
também a tradição clássica, a ponto de dar
um tom de cultura e magnificência às
propriedades rurais desses gentiluomini de
mentalidade ainda ligada à cidade; que,
enfim, soubesse edificar com grandiosidade e
economia." 153

Entre os arquitetos que atuaram nesse contexto, três se destacaram na busca de um modelo moderno ${ }^{154}$ de vila que atendesse as necessidades dos comitentes vênetos. Foram eles Michele Sanmicheli e Jacopo Sansovino, que já atuavam anteriormente no Norte da Itália, e Andrea Palladio, que iniciou sua atuação como arquiteto no vêneto, por volta de 1540. As propostas iniciais de Sanmicheli e Palladio foram próximas entre si e também próximas das vilas vênetas tradicionais, com uma loggia central e dois corpos laterais. Sansovino, em sua Villa Garzoni, também se aproximou dessa solução na fachada principal, mas o edifício todo estava mais próximo de um palácio citadino que de uma residência para o meio rural. Tanto Sansovino quanto Sanmicheli, de formação toscana, pensavam os edifícios em blocos isolados, enquanto a tradição veneta era de uma visão mais urbanística e de visuais contínuas ${ }^{155}$.

Entre todos esses arquitetos atuantes no Vêneto, foi Palladio quem, precocemente, identificou uma nova configuração tipológica, funcional e formal da vila enquanto espaço articulado de um organismo arquitetônico rural ${ }^{156}$.

\footnotetext{
152 Cf. Ackerman (1996, p.26).

153 Ackerman (1996, p.27). Tradução da autora, do italiano: "Per progettarli occorreva un architetto che, giunto alla maturità negli anni '30, sopravvivesse fino alla recessione dell'edilizia causata dal periodo di deflazione intorno al '70; che avesse la capacità - non comune nel Rinascimento, per mancanza di una tradizione precostituita - di progettare edifici funzionali, ma che padroneggiasse anche l'eredità cittadina; che, infine, sapesse edificare in modo grandioso e al tempo stesso economico."

154 Ackerman (1996, p.23) fala desse modelo moderno como sendo fundado sobre a tradição toscana.

${ }^{155}$ Cf. Ackerman (1996, p.23-27).

156 Cf. Puppi (2005, p.9).
} 


\section{Palladio e o Vêneto}

Andrea di Pietro della Gondola nasceu (Padova, 1508) e realizou sua formação na República Vêneta, onde se iniciava uma época de ouro, em um dos momentos mais intensamente criativos da história da arquitetura ${ }^{157}$. Sua aproximação à arquitetura ocorreu de forma muito diversa daquela comum aos arquitetos renascentistas dos grandes centros de renovação arquitetônica, como Roma, Florença e Veneza. Quando era ainda muito jovem, ele foi aprendiz de tagliapietre ${ }^{158}$, e ainda por muito tempo permaneceu exercendo trabalhos manuais, "antes de manusear o lápis e o esquadro aprendeu a dominar os movimentos da dura prática do canteiro: antes da abstrata prática do desenho experimentou a severa materialidade da construção"159.

Em 1537, ele participou da construção da Villa Godi, em cujos documentos aparece primeiramente como lapicida e depois como messer Andrea architetto ${ }^{160}$. Atualmente esse é tido como um dos primeiros projetos de vila de Andrea Palladio, ainda com forte vínculo com a arquitetura vêneta e poucas características da arquitetura renascentista que era praticada em Roma e Florença.

Somente em circunstâncias excepcionais, e encontrando as pessoas certas nos momentos apropriados, foi possível que um artesão da construção se tornasse um famoso arquiteto.

Aos trinta anos, Andrea participou das obras de ampliação da Villa de Cricoli, situada na periferia de Vicenza, e que teria sido a primeira construção renascentista lá realizada ${ }^{161}$. Seu proprietário, o Conde Giangiorgio Trissino (1478-1550), era

157 Cf. Ackerman (1996, p.3).

158 Filho de um pequeno empreendedor que alugava moinhos, com apenas treze anos ele se tornou aprendiz na bottega do scalpellino (operário que trabalhava a pedra ou o mármore para confecção de escadas, soleiras e afins) padovano Bartolomeo Cavazza, onde deveria ficar por cinco anos (Frommel, 2009, p.267). Após os três primeiros anos, entretanto, ele rompeu seu contrato, fugiu para Vicenza e se juntou à famosa bottega de Giovanni da Pedemuro e Girolamo Pittoni, na qual trabalhou por quatorze anos (Ackerman, 1972, p.4). De acordo com Portoghesi (2008, p.9), não existe documentação acerca da colaboração de Andrea com a bottega de Pedemuro, assim como não existe consenso dos estudiosos sobre as hipóteses levantadas. Apesar disso, o autor afirma que esses quatorze anos em que Andrea pertenceu à bottega certamente foram de grande importância em sua formação profissional e na construção de suas relações sociais.

159 Battilotti (2011, p.8). Tradução nossa, do original em italiano: "prima di maneggiare la matita e la squadra ha imparato a padroneggiare lo scalpello e la martellina: prima dela astratta pratica del disegno ha sperimentato la severa materialità dela costruzione".

160 Portoghesi (2008, p.9) explica que inicialmente ele constava nos documentos da construção da villa apenas como um escultor, mas que depois começou a ser indicado como mestre arquiteto.

161 Idem. 
um dos mais instruídos humanistas italianos do período ${ }^{162}$. Grande apreciador de artes, ele acompanhou de perto os trabalhos em sua propriedade, onde conheceu Andrea ${ }^{163}$.

"O classicismo militante de Trissino
reconhece na renovaça à antiga da facies
urbana o instrumento de valorizaça cultural
e de prestigio econômico da cidade, ainda
mais importante no momento em que Vicenza é
candidata, em 1537, a hospedar as sessóes do
Concilio (1545-63), antes que a escolha
definitiva recaisse sobre Trento."164

Trissino gostava de demonstrar aos outros sua cultura, era responsável pela educação de alguns jovens, dando-lhes formação cultural clássica e, tendo visto em Andrea um grande potencial, convidou-o para se juntar aos seus demais protegidos ${ }^{165}$. Andrea di Pietro della Gondola passou, então, a viver na corte, onde recebeu de Trissino o nome, de apelo clássico, com que ficou conhecido: Andrea Palladio ${ }^{166}$.

Já com idade avançada em relação aos seus colegas que estavam sendo iniciados nas disciplinas clássicas, Palladio foi direcionado por Trissino para uma formação mais específica, com - estudo dos textos de Vitruvio, Alberti e Serlio, engenharia, hidráulica, agricultura, teatro, topografia antiga e técnica militar, além do estudo das ruínas clássicas existentes no Vêneto e, especialmente em Verona. Dessa forma, ele adquiriu profundo conhecimento sobre as disciplinas diretamente vinculadas ao trabalho do arquiteto e conhecimentos superficiais sobre as demais, ou seja, seu perfil profissional estava mais próximo do especialista moderno que do homem universal albertiano" "Todavia, para atingir a plena

\footnotetext{
162 Cf. Frommel (2009, p.267).

163 Segundo Battilotti (2011, p.11) esse encontro foi documentado somente em 1538, mas certamente aconteceu pela primeira vez antes disso.

164 Battilotti (2011, p.11). Tradução da autora, do italiano: "Il 'classicismo militante' de Trissino ravvisa nel rinnovamento all'antica della facies urbana lo strumento di valorizzazione culturale e di prestigio economico della città, tanto più importante nel momento in cui Vicenza viene candidata, nel 1537, a ospitare le sessioni del Concilio (1545-63), prima che la scelta definitiva cada su Trento."

165 Cf. Ackerman (1972, p.5).

166 fazendo referência a Palas Atena, uma referência que ele já havia empregado ao batizar um anjo mensageiro com esse nome em seu poema épico L'Italia liberata dai Goti (Ackerman, 1972, p.5).

167 Cf. Ackerman (1972, p.5).
} 
maturidade artística era necessário o confronto com a grande escala que somente os monumentos de Roma podiam oferecer."168

Em 1541, acompanhado de Trissino, Palladio foi a Roma e deu início a uma outra etapa muito importante de sua formação a realização de viagens de estudo. Nessas viagens, ele tirava medidas dos edifícios e ruínas existentes e os desenhava, quase sempre empregando projeções ortogonais para documentar as formas arquitetônicas com exatidão ${ }^{169}$. Quando a observação das ruínas não resultava em um esquema simétrico Palladio o redesenhava, em seu ateliê, transformando-o em uma planta rigorosamente paladiana170, "ao investigar a arquitetura de Roma Palladio não está buscando exemplos, mas interlocutores para o diálogo que constantemente irá estabelecer entre sua arquitetura e aquela analisada, entre a teoria e a (ideia) e a sua prática." 171

Após essa primeira viagem, Palladio esteve em Roma acompanhado de Trissino outras duas vezes, uma entre 1545 e 1546 e outra de maior duração entre 1546 e 1547. Ele teria ainda tido outras duas breves estadas em Roma, em 1549 e $1554^{172}$, quando publicou dois pequenos guias da cidade, um sobre as igrejas e outro sobre as antiguidades romanas ${ }^{173}$.

Ackerman (1972) e Portoghesi (2008) citam Alvise Cornaro (1484-1566), Falconetto (1458-1534) e Serlio(1475-1554) como alguns dos outros personagens determinantes na formação de Palladio, ainda que não afirmem que Palladio os tenha conhecido pessoalmente.

Alvise Cornaro era um proeminente empreendedor agrícola e generoso mecenas que, com a colaboração do pintor Falconetto, foi responsável pela primeira tentativa de superar o Renascimento romano na região do vêneto. Ele se dedicou à prática e à teoria da arquitetura, mas sempre defendendo a proximidade entre ambas. Cornaro escreveu um pequeno tratado antirromano, em oposição aos preceitos teóricos ditados por Vitruvio e pelos humanistas que, para ele, não eram úteis a

\footnotetext{
168 Battilotti (2011, p.13). Tradução da autora, do italiano: "Tuttavia per raggiungere la piena maturità artística era necessário il confronto con la grande scala che solo i monumenti di Roma potevano offrire."

169 Cf. Ackerman (1972, p.9).

170 Cf. Wittkower apud Lancha (2009, p.xii).

171 Cf. Lancha (2009, p.xiii).

172 Battilotti (2011, p.13) cita as estadias romanas de Palladio registradas pelo biógrafo Paolo Gualdo.

173 Essas publicações são "Lantichita di Roma" e "Descritione de le chiese di Roma", ambos de 1554 (Puppi, 1988).
} 
quem pretendesse construir habitações cômodas, salubres e econômicas ${ }^{174}$.

A postura de cornaro era extremamente antitética à de Trissino, e certamente contribuiu para a atitude prática e empírica de Palladio, assim como para seu distanciamento de normas rígidas e dogmatismos teóricos.

Sebastiano Serlio atuou quase sempre em Roma até 1527 quando, após o saque, dirigiu-se a Veneza. Ele teria influenciado Palladio de duas formas distintas. A primeira por seus projetos e personalidade, e a segunda - e talvez mais importante - através de seu tratado Tutte l'opere d'architettura et prospettiva (1517). O tratado, dividido em sete livros, era quase um catálogo de ilustrações comentadas, modificando a prática que vinha desde Alberti onde as ideias deveriam ser transmitidas por meio de textos. Foram os livros de Serlio que apresentaram a Roma Antiga a Palladio e, muito provavelmente, eles é que aguçaram seu interesse em conhecê-la pessoalmente, o que também teria acontecido com projetos modernos como o Cortile del Belvedere e a Villa Madama.

Palladio também teria conhecido e sido influenciado por obras de seus precursores Bramante, Raffaello Sanzio, Baldassare Peruzi, Antonio da Sangallo il Giovane, assim como outras de arquitetos que eram seus contemporâneos, como Jacopo Barozzi da Vignola, Pirro Ligorio e Michelangelo"175. "Dessas experiências ele pega elementos e sugestões que, se é possível identificar nos primeiros projetos, são metabolizados aos poucos, reelaborados e reconduzidos à sua peculiaríssima maneira e aos seus princípios, reduzindo-se a indefiníveis sugestões."176 Pode-se perceber O efeito desse processo de estudo já nos projetos que Palladio realizou ao retornar de sua primeira viagem a Roma, elementos presentes na obra de Falconetto se misturavam a outros encontrados em Bramante e Sangallo $0^{177}$.

Palladio teve uma intensa atuação como arquiteto, de acordo com Puppi ${ }^{178}$, há 143 projetos atribuídos a ele, dentre os

\footnotetext{
174 Cf. Ackerman (1972, p.6).

175 Cf. Battilotti (2011, p.14).

176 Cf. Battilotti (2011, p.14). Tradução da autora, do italiano "Da queste esperienze egli prende spunti e suggerimenti che, se é possibile precisare nei primi progetti, vengono via via metabolizzati, rielaborati e ricondotti ala sua particolarissima maneira e ai sui principi, riducendosi a indefinibili suggertioni."

177 Cf. Frommel (2009, p.268).

178 Cf. Puppi (1999).
} 
quais 36 são vilas rurais ou suburbanas. Na Tabela 3 pode-se ver a lista em ordem cronológica de todas essas 36 vilas, com destaque em negrito para as que foram publicadas no tratado. Todas as vilas projetadas por Palladio eram para localidades vênetas, a maior parte delas situadas nas províncias de Vicenza, Pádua, Treviso e Veneza.

\begin{tabular}{|c|c|c|c|}
\hline Vila & Localidade & Província & $\begin{array}{c}\text { Data } \\
\text { estimada } \\
\text { do } \\
\text { projeto } \\
179\end{array}$ \\
\hline Villa Godi & Lonedo di Lugo Vicentino & Vicenza & 1537 \\
\hline Villa Piovene & Lonedo di Lugo Vicentino & Vicenza & $1539 * *$ \\
\hline Villa Forni Cerato & Montecchio Precalcino & Vicenza & $1541^{180}$ \\
\hline Villa Gazzotti & Bertesina & Vicenza & 1541 \\
\hline $\begin{array}{l}\text { Villa Valmarana } \\
\text { Bressan }\end{array}$ & Monticello Conte Otto & Vicenza & 1542 \\
\hline Villa Pisani & Bagnolo di Lonigo & Vicenza & $1542 * \star$ \\
\hline Villa Thiene & Quinto Vicentino & Vicenza & $1542 *$ \\
\hline $\begin{array}{l}\text { Villa Muzani detta } \\
\text { La Pisa }\end{array}$ & Malo & Vicenza & $\begin{array}{l}1545 * * \\
181\end{array}$ \\
\hline $\begin{array}{l}\text { Villa Contarini } \\
\text { degli Scrigni }\end{array}$ & Piazzola Sul Brenta & Pádua & $1546 * \star$ \\
\hline Villa Arnaldi & Meledo di Sarego & Vicenza & 1547 \\
\hline Villa Caldogno & Caldogno & Vicenza & $1548 * *$ \\
\hline
\end{tabular}

179 As datas e a localizações das vilas foram obtidas no Centro Internazionale di Studi di Architettura Andrea Palladio, e estão disponíveis em: <http://mediateca.palladiomuseum.org/palladio/opere.php>, acesso em 09/04/2014. $180 \mathrm{Na}$ página do Centro Internazionale di Studi di Architettura Andrea Palladio consta a informação de que o projeto da Villa Forni foi realizado após 1564. Tendo em vista que nas demais fontes obteve-se a informação de que a construção ocorreu entre 1541 e 1542 (Wundram; Pape, 2008, p.26), em 1541 o projeto já deveria estar concluído e por isso essa foi a data considerada.

181 Não foi encontrada uma data precisa para o projeto e a construção das Villa Muzani, destruída em 1919, Villa Schio e Villa Mocenico Marocco. Rybczynski (2002, p.257) é quem chega mais perto disso ao agrupar as vilas de Palladio em décadas. A Villa Muzani está entre as projetadas entre 1540 e 1550, a Vila Schio na década seguinte, entre 1550 e 1560 e a Villa Mocenico Marocco na última década, entre 1560 e 1570. 


\begin{tabular}{|c|c|c|c|}
\hline Villa Saraceno & Finale di Agugliaro & Vicenza & $1548 * \star$ \\
\hline Villa Angarano & Bassano del Grappa & Vicenza & 1548 \\
\hline Villa Poiana & Poiana Maggiore & Vicenza & 1549 \\
\hline Villa Chiericati & Grumolo delle Abbadesse & Vicenza & $\begin{array}{l}\text { Após } \\
1550\end{array}$ \\
\hline Villa Pisani & Montagnana & Pádua & $1552 * \star$ \\
\hline Villa Cornaro & Piombino Dese & Pádua & 1552 \\
\hline Villa Ragona & $\begin{array}{l}\text { Ghizzolle di } \\
\text { Montegaldella }\end{array}$ & Vicenza & $1553 * \star$ \\
\hline Villa Porto & Vivaro di Dueville & Vicenza & 1554 \\
\hline Villa Barbaro & Maser & Treviso & $1554 * \star$ \\
\hline Villa Foscari & Gambarare di Mira & Veneza & $1554 *$ \\
\hline Villa Badoer & Fratta Polesine & Rovigo & $\begin{array}{l}1554- \\
1555 * \star\end{array}$ \\
\hline Villa Mocenico & Dolo & Veneza & $1554 *$ \\
\hline Villa Zeno & Cessalto & Treviso & $1554 *$ \\
\hline Villa Schio & Montecchio Precalcino & Vicenza & $1555 \star \star$ \\
\hline Villa Emo & Fanzolo & Treviso & 1556 \\
\hline Villa Thiene & $\begin{array}{l}\text { Cicogna di Villafranca } \\
\text { Padovana }\end{array}$ & Pádua & 1556 \\
\hline Villa Repeta & Campiglia dei Berici & Vicenza & $1560 *$ \\
\hline $\begin{array}{l}\text { Barchesse grandi di } \\
\text { Villa Pisani }\end{array}$ & Bagnolo di Lonigo & Vicenza & $1561 * *$ \\
\hline Villa Sarego & Miega di Cologna Veneta & Verona & 1562 \\
\hline Villa Valmarana & Bolzano Vicentino & Vicenza & $1563 * \star$ \\
\hline $\begin{array}{l}\text { Villa Mocenigo } \\
\text { Marocco }\end{array}$ & Marocco & Veneza & $1565 *$ \\
\hline Villa Sarego & Santa Sofia di Pedemonte & Vicenza & 1565 \\
\hline Villa Almerico & Vicenza & Vicenza & $1566-$ \\
\hline
\end{tabular}




\begin{tabular}{|l|l|l|l|}
\hline Capra & & & 1567 \\
\hline Villa Trissino & Meledo di Sarego & Vicenza & $\begin{array}{l}1553 * \star \\
1567\end{array}$ \\
\hline Villa Porto & Molina di Malo & Vicenza & 1570 \\
\hline
\end{tabular}

Tabela 3 - Todas as vilas projetadas por Palladio em ordem cronológica. *data estimada; **cerca de; Fonte: Adaptado de Puppi (1999).

No proêmio do Livro I do I Quattro Libri dell'Architettura, Palladio destaca seu início precoce na arquitetura, mas não faz nenhuma menção à prática que teve nos canteiros

"Conduzido por natural inclinação, dediquei-
me nos primeiros anos ao estudo da
Arquitetura (...), propus-me ter como mestre
e guia Vitruvio, o qual é o único antigo
escritor desta arte, e me pus à investigação
dessas relíquias dos antigos edifícios, os
quais, malgrado o tempo e a crueldade dos
bárbaros, resistiram"182

O tratado de arquitetura como o próprio nome sugere, é subdividido em quatro livros, em cada um dos quais é desenvolvido um argumento diferente e também apresentada uma diagramação diferente ${ }^{183}$. Esses livros possuem um caráter manualístico, que era exatamente o que Alberti pretendia evitar em seu De re Aedificatoria, mas que foi de grande ajuda para a difusão de suas vilas e para o surgimento, séculos mais tarde, do Paladianismo.

Por outro lado, Battilotti ${ }^{184}$ afirma que, se o tratado foi - grande responsável pela difusão da arquitetura paladiana, ele também contribuiu para a distorção de sua compreensão e para diminuir a intensidade criativa das composições:

"definitivamente os Quatro Livros são
instrumentos indispensáveis para compreender
Palladio, mas devem ser manejados com
consciência histórica e com cautela crítica,
sem esquecer que na realidade da construçõo
Palladio geralmente não atende suas regras e

182 Cf. Palladio, Livro I, Proêmio (2009, p.5).

${ }^{183}$ Cf. Lancha (2006)

184 Battilotti (2011, p.8). Tradução da autora, do italiano: "in definitiva i Quattro Libri sono strumenti indispensabili per comprenderne Palladio, ma vanno maneggiati con consapevolezza storica e con cautela critica, senza dimenticare che nella realtà dela costruzione Palladio disattende in genere alle sue regole e che quasi mai i disegni pubblicati corrispondono ai suoi progetti presentati e ai suoi edifici costruiti." 
que quase nunca os desenhos publicados correspondem aos seus projetos apresentados e aos seus edifícios construídos."

No Livro I são apresentados os elementos fundamentais do projeto, com enfoque principal dado ao texto, ou seja, nesse primeiro livro, os desenhos são inseridos para ilustrar as idéias expostas.

O Livro II, em que versa sobre as construções particulares, Palladio começa com textos, mas logo inverte essa relação ao apresentar seus projetos para as casas da cidade. Na sequência ele continua apresentando desenhos baseados no texto de Vitruvio para os diferentes tipos de átrios e salas, assim como das casas particulares dos gregos. Por um momento ele volta ao texto para falar sobre a escolha dos lugares para construção das vilas e também de sua compartimentação. Desse ponto em diante, os desenhos dos projetos tornam-se protagonistas do Livro II, o texto fornece somente informações bastante pontuais sobre os proprietários, o local ou mesmo os artistas responsáveis pela decoração dos edifícios. Aqui as imagens ganham maior destaque e todo o livro é como se fosse composto apenas para descrevê-las.

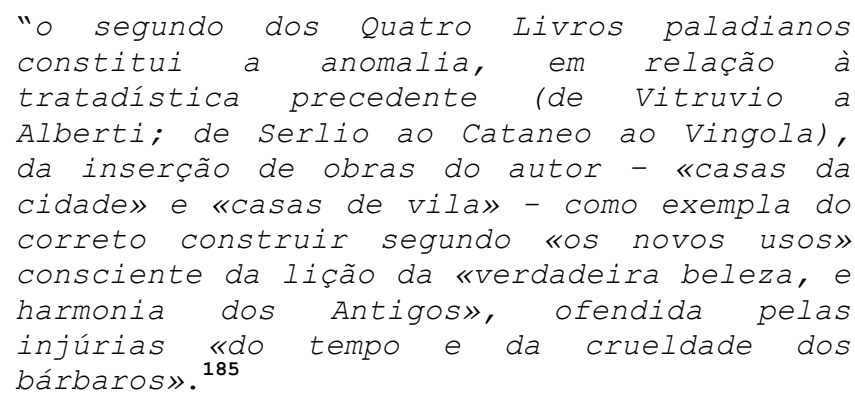

No livro III, Palladio apresenta seus próprios projetos assim como no II, mas com uma organização similar à do primeiro: o texto aparecendo como elemento principal e as imagens utilizadas para ilustrá-lo, o que deixa clara a confiança de Palladio nas imagens como o melhor veículo para expor suas ideias. Nesse livro são apresentadas obras públicas seguindo uma ordem cronológica.

\footnotetext{
185 Puppi (2005, p.9). Tradução da autora, do italiano: "il secondo dei Quattro Libri palladiani costituisce l'anomalia, rispetto alla precedente trattatistica architettonica (da Vitruvio all'Alberti; dal Serlio al Cataneo al Vignola), dell'inserimento di opere dell'autore - "case della città» e «case di villa» quali exempla di corretto fabbricare secondo un' «usanza nuova» consapevole della lezione della "vera bellezza, e leggiadria degli Antichi», offesa dalle ingiurie "del tempo e della crudeltà dei barbari»."
} 
No livro IV, Palladio apresenta desenhos dos edifícios que visitou em suas viagens de estudos. Assim como no II, o enfoque principal está nos desenhos, mas aqui eles possuem uma apresentação menos sistematizada. Segundo Lancha ${ }^{186}$, na representação de seus próprios projetos, Palladio emprega um rigor muito maior - que se percebe no decorrer desse quarto livro.

Durante essas viagens, Palladio desenhava e tomava medidas dos edifícios visitados, fazia croquis utilizando de projeções ortogonais, com as quais procurava resgatar com precisão a forma arquitetônica. Esse processo de estudo e conhecimento se destaca como um momento de fundamental importância em sua formação. Os desenhos que realiza sobre a antiguidade são tão importantes quanto os seus próprios projetos, uma vez que passam a ser o testemunho de suas opções, de suas escolhas diante da obra de arquitetura. Esses estudos que ele realiza não são imparciais, mas, pelo contrário, já apresentam o resultado de uma análise prévia dessas formas e proporções, corrigidas e reorganizadas segundo suas preferências. O programa de Palladio certamente é restituir ao mundo moderno as formas e usos antigos, segundo a bela maneira dos modernos ${ }^{187}$.

A importância da atuação de Palladio não se restringe à teorização proposta nos quatro livros de seu tratado, mas às numerosas construções que realizou, especialmente nas cidades de Veneza e Vicenza. Observando-se o Quattro Libri se percebe que, como foi citado anteriormente, ele é indissociável de sua atuação como arquiteto. "Em sua arquitetura, como em seu tratado, nunca transparece o gosto da "ruína", que é tão frequente em toda a arquitetura do Renascimento, de Alberti a Bramante, e que atesta uma consciência viva da historicidade da arte clássica"188. Isso ocorre não só pelo emprego de seus próprios projetos como exemplos, mas por ele empregá-los de forma a validar as teorias propostas. Assim, ele estabelece uma via de mão dupla, em que os projetos alimentam o desenvolvimento das teorias e, por elas, são modificados, já que para palladio os elementos resgatados da antiguidade constituíam um vocabulário vivo e atual.

186 Cf. Lancha (20029, p.xvii).

187 Cf. Magagnato (1980), apud Lancha (op cit).

188 Cf. Argan (1999, p. 408). 



\section{A vila Para Alberti e Palladio}

\section{Organização dos tratados e as vilas}

As recomendações de Alberti para o projeto de vilas aparecem distribuídas ao longo de vários livros do tratado. As primeiras aparecem no Livro I, sobre o Delineamento, quando ele faz orientações gerais que servem para todos os tipos de edifícios, dividindo a construção em seis partes: a escolha da região, a determinação da área, a compartimentação, o desenho das paredes, a cobertura e as aberturas.

Outras são encontradas no Livro V, que trata do projeto de edifícios particulares, onde Alberti estabelece diretrizes específicas para o projeto residencial, algumas comuns a todas residências e outras apenas para as vilas. Ao falar das vilas, ele faz outra subdivisão, dessa vez segundo o tipo de proprietário: chefes de Estado, homens livres e famílias camponeses.

Por fim, no Livro IX, sobre a ornamentação dos edifícios particulares, também são encontradas orientações para a compartimentação dos edifícios e a obtenção da concinidade (concinnitas) e do decoro.

- tratado de Palladio, por sua vez, possui uma organização muito mais lineares e sintéticas para o projeto de vilas, algumas encontradas no primeiro livro, junto dos materiais de construção e técnicas construtivas, e outras no livro dois, onde apresenta seus próprios projetos residenciais como exemplos.

\section{De re Aedificatoria}

Como vimos no capítulo anterior, o tratado de Alberti é dividido em dez livros: I - O delineamento dos edifícios; II - Os materiais; III - A construção; IV - Edifícios para fins universais; V - Edifícios para fins particulares; VI - 0 ornamento; VII - O ornamento de edifícios sagrados; VIII - O ornamento de edifícios públicos profanos; IX - O ornamento de edifícios privados; $\mathrm{X}$ - O restauro das obras.

Ao longo dos dez livros de seu tratado, Alberti fornece diversas orientações para o projeto de arquitetura, algumas das quais se aplicam a todos os tipos de construção, outras apenas às obras privadas, outras ainda às residências, e algumas especificamente às vilas. 
No Livro I Alberti lista e descreve as seis partes que, para ele, compõem a arte de construir ${ }^{1}$

- Região - porção de terreno que circundará a construção, condição geográfica em que é construído o edifício;

- Área - uma parte da região circundada por muros para um uso específico. Também é vista como área toda parte interna dos edifícios em que seja possível caminhar;

- Compartimentação - divisão da área em partes menores, onde o edifício é relacionado a um corpo, composto de edifícios menores, como membros unidos e articulados entre si;

- Paredes - cada estrutura erigida da base ao topo de qualquer edifício, para dividir os ambientes internamente ou para suportar a cobertura;

- Coberturas - não somente o telhado, mas também toda estrutura que esteja acima da cabeça de seus usuários;

- Aberturas - assim chamadas porque permitem aos homens e aos objetos entrar e sair de qualquer parte do edifício.

Nas explicações sobre os diversos temas, divididos por capítulos, são apresentadas noções gerais de geometria. Quando Alberti fala sobre a área, no capítulo 3, ele faz uma breve descrição geométrica de como podem ser compostas essas áreas, com linhas curvas e retas, tendo como base os edifícios antigos.

No Livro II Alberti fala sobre os materiais, abordando questões práticas, ensinamentos tecnológicos e fazendo considerações sobre a percepção geral a respeito das obras bem ou mal construídas. Para ele, todos são capazes de perceber os erros no projeto, ainda que nem todos sejam capazes de identificar onde está o problema. De Fusco associa essa capacidade de ter consciência da beleza independentemente do grau de cultura e instrução com o conceito que Kant expressa em Crítica do Juízo: "o belo é o que se apresenta sem conceito e como objeto de um deleite comum $^{2}$. O restante desse livro é destinado à escolha dos materiais de construção, com várias referências aos

\footnotetext{
Alberti, Livro I, Cap.II-XII, (2011a, p.147-183).

2 Cf. Lukomski, G.K. I maestri della architettura classica. Hoepli: Milano, 1933, p.320, apud De Fusco (2003, p.129). Tradução da autora, do italiano: "Il bello è ciò che si presenta senza concetto e come oggetto di una delizia comune."
} 
pressupostos estabelecidos por Vitruvio e também por outros autores antigos como Aristóteles, Plínio e Teofrasto ${ }^{3}$.

No Livro III Alberti fala sobre a construção, detalhando as técnicas relacionadas a cada etapa da construção de edifícios, e retomando diversas recomendações de Vitruvio, Plínio o Velho e Varrão, entre outros autores antigos.

- Livro IV é destinado aos edifícios para fins universais, entre os quais é colocada a cidade. Para Alberti, eles são construídos em função da diversidade do ser humano e, portanto, passa a destacar o que diferencia os homens. A partir do capítulo 2 Alberti entra diretamente na discussão urbanística, com a definição das razões para que seja fundada uma cidade, o lugar mais adequado para isso e também as melhores condições, de onde surge o argumento que essa cidade deveria ser livre de todos os defeitos referidos no primeiro livro. Em relação aos diferentes tipos de relevo possíveis são feitas várias considerações sobre os prós e contras, da mesma forma que ocorre com a descrição do perímetro ideal para a cidade e da distribuição de suas partes, sob diferentes pontos de vista. Assim como a arquitetura deve variar segundo a diversidade dos homens, a cidade deve variar de acordo com a diversidade dos lugares. Também é discutido o posicionamento das ruas - sobretudo do ponto de vista militar, das pontes, dos sistemas de esgoto e dos portos. O argumento das obras públicas não é esgotado, pois aquelas que são consideradas exclusivas para poucos, como templos, santuários, basílicas, lugares para espetáculos, são discutidas nos livros VII e VIII.

Essa discussão desenvolvida por Alberti sobre a cidade é fortemente influenciada pelo tratado de Vitruvio e também pela cidade medieval, embora no geral as teorias albertianas busquem superar a ambos:

"O De re aedificatoria de Alberti... abre
a série dos tratados sobre a arte de
construir, em que é incluída, sem exceção
e como parte integrante, o projeto da
cidade. Mas enquanto a descrição
albertiana da cidade resgata os esquemas
do planejamento medieval, lidos agora sob
a ótica vitruviana, para constituir um
modelo racionalizado, com o tratado de

3 O próprio Alberti afirma (Livro II, Cap.V) que buscou referências a materiais para construção de edifícios nos escritos desses e outros autores. 


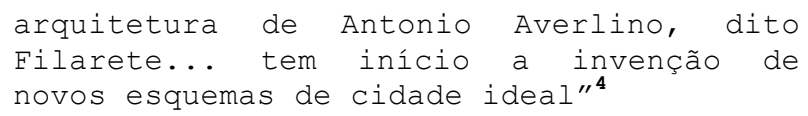

Para De Fusco ${ }^{5}$, não há dúvidas de que Alberti teoriza sobre experiências urbanísticas reais, assim como Vitruvio, avaliando constantemente seu discurso com exemplos históricos, com um processo predominantemente pragmático. Mas enquanto Alberti faz um verdadeiro tratado urbanístico abordando a cidade sob os mais diversos aspectos, Vitruvio se refere à cidade somente para inserir elementos tipológicos e construtivos.

Outro ponto interessante desse livro é Alberti defender a necessidade do planejamento dessas cidades, em contraposição à cidade medieval de crescimento desordenado. Para De Fusco ${ }^{6}$, Alberti propõe um conceito de cidade capaz de acolher os futuros desenvolvimentos da comunidade, não somente como previsão demográfica, mas devendo satisfazer todas as funções da vida, desde a administração à arte e do comércio ao tempo livre.

Outra contribuição de Alberti provém da aplicação do conceito mediocritas em relação ao espaço urbano, para justificar que a cidade deve atender à justa medida, evitando os exageros. Essa justa medida, proposta para a cidade, parece se relacionar com as justas proporções albertianas propostas para os edifícios.

O discurso sobre o urbano continua no decorrer do Livro V, que trata das obras particulares. Entre os diferentes tipos de edifícios, correspondentes aos homens diferentes, não foi feita menção no livro anterior aos que se relacionam aos fatores políticos. No primeiro capítulo, então, ele começa falando sobre as moradias dos encarregados pelo comando e pela administração do estado, funções que podem ser concentradas nas mãos de somente uma ou de mais pessoas, e cujo poder pode ser mantido pela justiça, ou pela força. Dependendo das características do governo, variam também as características da moradia dos seus governantes, e também as configurações gerais da cidade.

Para cada forma de governo corresponde uma determinada organização espacial da cidade. Independentemente das formas

\footnotetext{
4 Cf. Astengo, G. Urbanistica dell'Enciclopedia Universale dell'Arte. Vol. XIV, col. 571, apud De Fusco (2003, p.141). Tradução da autora, do italiano: ${ }^{5}$ Cf. De Fusco (2003, p.141-142).

6 Idem, p.142.
} 
propostas, "a novidade do método é constituída do fato que o autor elabora o projeto de construção de toda uma cidade, de que cada particular seja subordinado ao conceito predominante da cidade entendida como um todo orgânico."7 Ao contrário do que ocorria no período medieval, onde a preocupação com os vizinhos era apenas no intuito de copiá-los ou superá-los. "Alberti prefigura a ideia de um organismo urbano totalmente novo e distinto de que não é fácil formar uma imagem, mas que de qualquer modo reflete uma sólida estrutura conceitual."8

$\mathrm{Na}$ sequência Alberti fala da construção de fortes, moradias para os notáveis, templos, monastérios, academias ${ }^{9}$, lugares para assistir os pobres e os marginais, o senado, o acampamento, as construções navais, os equipamentos (como arsenais, celeiros, etc.), os presídios, e as residências que, por sua vez, também são subdivididas em casas urbanas, vilas camponesas e vilas senhoriais.

Também são discutidas as diferenças entre as casas urbanas, que devem inspirar maior autoridade, e as casas de vilas, que são rurais, onde se podem permitir todos os prazeres de uma existência festiva e amena. Enquanto nas casas de cidade a planta e a altura da casa devem ser pensadas tendo em conta os edifícios vizinhos, nas vilas temse maior liberdade.

Após falar sobre o desenho e a composição da forma, a escolha dos materiais, métodos e tipologias do edificar, a partir do Livro VI, Alberti promove uma grande mudança de direção na obra, e até o Livro IX passa a tratar do mérito da escolha da linguagem e dos ornamentos. Sobre essa mudança de rumo, Giontella ${ }^{10}$ aponta o depoimento do próprio autor, no primeiro capítulo desse livro, como sugerindo que ele tenha se cansado e, muito provavelmente, estava retomando a obra após ter feito uma pausa quando concluiu os cinco primeiros livros:

\footnotetext{
7 Blunt, A. Le teorie artistiche in Italia dal Rinascimento al Manierismo. Torino: Einaudi, 1966, p.22, apud De Fusco (2003, p.145). Tradução da autora, do italiano: "La novità del metodo è costituita dal fatto che l'autore elabora il progetto di costruzione di un'intera città, di cui ogni particolare è subordinato al concetto predominante della città intesa come un tutto organico."

${ }^{8}$ Cf. De Fusco (2003, p.145).

9 Cf. Alberti (2011a, p.335) fala da palestra grega, local em que as pessoas se reuniam para práticas de esportes e também para atividades sociais, como se reunir e conversar.

10 Cf. Giontella (2010, p.209).
} 


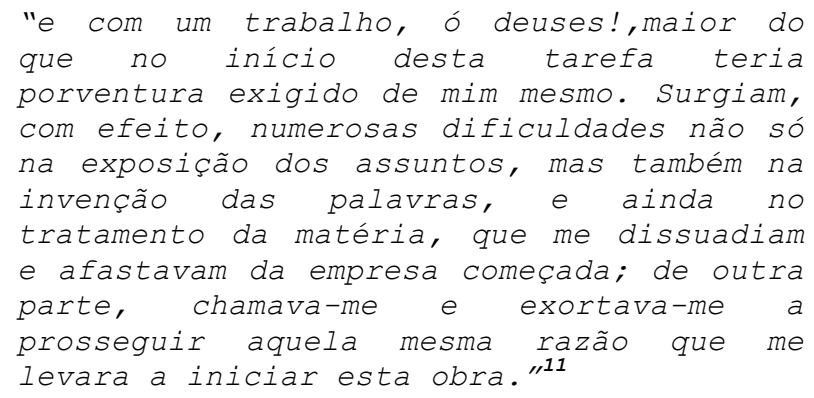

Também nesse ponto do tratado em que apresenta certa hesitação para com sua empresa, Alberti faz algumas de suas mais duras críticas a Vitruvio, principalmente no que se refere à linguagem por ele empregada. Daí se pode pensar que, muito provavelmente, a interlocução que pretendia fazer com o tratado de Vitruvio, sua única referência, também tinha se mostrado mais difícil que o esperado.

No segundo capítulo desse livro, após criticar tão duramente Vitruvio sem considerar o ambiente hostil que ele possa ter encontrado quando da redação de seu tratado, Alberti retoma a tríade vitruviana, firmitas, utilitas e venustas (solidez, utilidade e beleza). Após ter exaurido a discussão sobre as duas primeiras, ele decide tratar da terceira, "de todas a mais nobre e mas necessária"12.

Apesar das palavras de Alberti, que associam os cinco primeiros livros a firmitas e utilitas, e os demais a venustas, em suas explicações constantemente ele funde os três conceitos. Em um primeiro momento, a referência à beleza como sendo o princípio mais belo e necessário, parece contradizer o que Alberti tinha falado no Livro I, onde a beleza surgia por meio do uso. De Fusco ${ }^{13}$, entretanto, defende o sentido instrutivo de tais afirmações dentro do contexto em que cada uma delas aparece. Essa, digamos, segunda nuance dada à beleza é faz jus ao contexto em que Alberti se põe a falar sobre a relação entre beleza, ornamento e as diferenças entre os dois:

"o ornamento será realmente uma espécie
de luz subsidiária da beleza e como que o
seu complemento. Daqui penso que se torna
evidente que a beleza é como que algo de
próprio e inato, espalhado por todo o
corpo que é belo; ao passo que o ornato é

11 Cf. Alberti, Livro VI, Cap.I (2011a, p.373).

12 Cf. Alberti, Livro VII, Cap. II (2011a, p.375)

${ }^{13}$ Cf. De Fusco (2003, p.155). 
da natureza do artificial e acrescentado mais que do inato."14

As diferenças entre beleza e ornamento, entretanto, muitas vezes são abandonadas pelo próprio Alberti no decorrer do tratado. O conceito de beleza, quase utópico por ser tão dificilmente alcançado, permanece teórico, enquanto o de ornamento é exaustivamente detalhado ${ }^{15}$. Panofsky aponta um possível paralelo entre a dicotomia albertiana belezaornamento e a vitruviana comensurabilidade-proporção (symmetria-eurytmia), em que um é o princípio estético e o outro o método para colocá-lo em prática.

Nesse livro ao falar sobre o conceito de beleza, Alberti retorna à comensurabilidade (symmetria) de Vitruvio o acordo entre as partes segundo uma determinada razão, e acrescenta seus próprios princípios, já abordados nos livros I e II, concinnitas e nihil addi - que não se pode acrescentar, retirar ou mudar algo sem piorar a obra. De Fusco ${ }^{16}$ aponta uma possível redundância nessa justaposição de comensurabilidade (symmetria) e concinnitas, já que a primeira contém, em sua própria definição, os princípios da segunda.

O Livro VII é destinado à ornamentação dos edifícios sacros. Ao se dirigir especificamente à beleza (venustas), o autor retomando seu conceito de mediocritas, destacando a necessidade de se equilibrar com as duas outras características fundamentais (firmitas e utilitas), pois "onde houver alguma deficiência, todo o mais não merece aprovação"17.

No primeiro capítulo Alberti faz algumas considerações gerais sobre quais seriam esses edifícios ditos sacros, que vão muito além dos templos. São sacros os muros - que fecham e protegem a cidade; as basílicas, onde se administra o direito - já que a piedade é a primeira fonte de justiça, que é ela própria um dom divino; os monumentos comemorativos que remetem à justiça e à religião. Além disso, esses edifícios fariam parte da ornamentação da cidade, junto com os altares nas esquinas, as ruas bem dimensionadas e posicionadas, as praças, os edifícios e até mesmo o

\footnotetext{
14 Cf. Alberti, Livro VI, Cap. II (2011a, p.378).

${ }^{15}$ Cf. De Fusco (2003, p.160).

16 Idem, p.157-158.

17 Cf. Alberti, Livro VII, Cap. I (2011a, p.428).
} 
zoneamento desses edifícios segundo suas funções, como fica claro em:

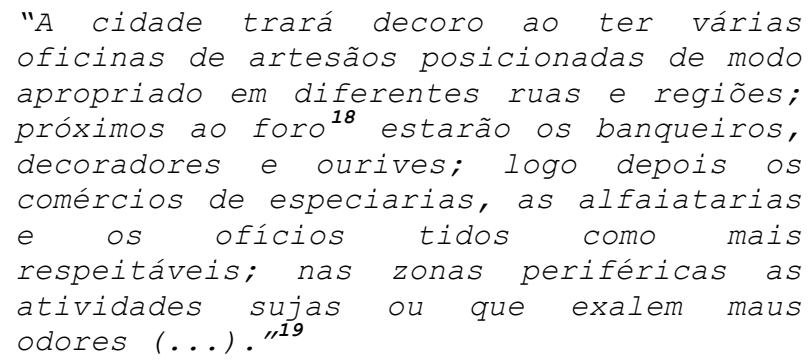

No capítulo 3, Alberti entra no caso específico dos edifícios sacros, já que para ele um templo finamente curado é sem dúvida o maior e principal ornamento da cidade. Desde o início desse capítulo percebem-se em suas palavras algumas referências às catedrais góticas, como em

"gostaria que no templo haja tanta beleza
que não seja possivel imaginar, em
qualquer outro lugar, algum aspecto mais
ornamentado; e desejo que em todos os
pormenores seja de tal modo cuidado que
quem entra estremeça estupefacto de
admiraço pela sua imponência, e
dificilmente se coíba de exclamar em voz
alta que é digno de Deus aquele lugar que
contempla."2o

Ao mesmo tempo em que ele se pretende pagão, ao afirmar, por exemplo que o templo seja digno de 'um' deus, contrariando o princípio medieval de um único Deus, o próprio fato de chamar este espaço de 'templo' e não 'igreja', é uma herança medieval. Da mesma forma ocorre com o desejo, indicado pelo autor, de provocar estupor, que remete às catedrais góticas e sua configuração formal e espacial visando manifestar na arquitetura a pequenez do homem frente a Deus. Esse dualismo paganismo-cristianismo estará constantemente presente na obra de Alberti, e posteriormente será revivido e reinterpretado em todos os tratados do século $\mathrm{XVI}^{21}$.

No livro VIII é discutida a ornamentação dos edifícios públicos profanos. Aqui são reunidos não somente edifícios, mas diversos espaços e elementos públicos como ruas (civis e

\footnotetext{
18 Para os antigos romanos, era a praça principal da cidade, onde estava seu centro comercial, administrativo e judiciário.

19 Alberti, Livro VII, Cap.I (2011a, p.432).

20 Alberti, Livro VII, Cap.III (2011a, p.436).

${ }^{21}$ Cf. De Fusco (2003, p.167).
} 
militares), pontes, túmulos, arcos citadinos e até mesmo inscrições nos edifícios, em uma discussão sobre ornamento muito diferente do que se vê no livro anterior. A abordagem feita aqui se afasta um pouco da discussão sobre ordens e elementos arquitetônicos para composição formal, enquanto se aproxima da discussão mais genérica feita no Livro I acerca da região, área, etc. Também são discutidos nesse livro os edifícios para espetáculos, teatros, anfiteatros, circos, a cúria sacerdotal, o senado e as termas, mas sem os detalhes empregados na apresentação dos templos.

- argumento de que trata o Livro IX é a ornamentação dos edifícios privados, que, segundo Alberti, deve ser empregada com parcimônia, de forma que nenhum deles seja mais belo que os templos - retomando o assunto discutido no Livro VII: "prefiro que, nos edifícios privados, aos mais ricos fale alguma coisa que contribua para o ornamento, a que os mais pobres critiquem o luxo dos ricos em algum aspecto" 22 . Giontella ${ }^{23}$ identifica nessas recomendações o conceito de mediocritas, que para Alberti era fruto de bom gosto e exemplo de virtude e moderação.

Entretanto, na sequência do texto o próprio Alberti afirma que os sábios devem se afastar da ornamentação excessiva e de materiais como ouro, marfim e bronze, para não atrair inveja de outras pessoas, "mas usará com requinte das coisas modestas e com moderação das coisas requintadas" ${ }^{24}$. Os fatores de maior importância no ornamento desses edifícios seriam, então: a distribuição interna dos espaços e a concordância no desenho.

O livro IX parece encerrar o tratado, já que retoma em seus quatro últimos capítulos o que foi discutido anteriormente de forma tão prática que o autor parece querer compensar as teorizações dos livros anteriores ${ }^{25}$. Esse livro também é aquele que apresenta uma das principais características de toda a obra pela forma com que Alberti "se aproxima da beleza-tipo fazendo uma média mais ou menos aritmética"26, demonstrando o distanciamento que ele toma das concepções neoplatônicas. De fato, as principais

\footnotetext{
22 Alberti, Livro IX, Cap. I (2011a, p.575).

${ }^{23}$ Cf. Giontella (2010, p.346).

24 Alberti, Livro IX, Cap. I (2011a, p.576).

${ }^{25}$ Cf. De Fusco (2003, p.186).

26 Cf. Blunt, A. Le teoria artistiche, op cit, p.32-35, apud De Fusco (2003, p.186). Tradução da autora, do italiano: "perviene alla bellezza-tipo facendo una media più o meno aritmetica."
} 
características das teorias albertianas estão, distantes do misticismo e da fantasia de seus contemporâneos, fundadas sobre o racionalismo, o classicismo, o método científico e a fé absoluta na natureza.

No livro $\mathrm{X}$, Alberti fala do restauro dos edifícios, motivado em grande parte pela situação em que se encontrava Roma, onde habitava nesse momento a serviço de Nicolau V, como já foi mencionado anteriormente.

o principal ponto desse livro, além, é claro, de sua contribuição para o campo do restauro e do patrimônio histórico, foi seu importante conceito de concinnitas caracterizado "não somente como acordo ou concerto entre as partes internas de uma dada estrutura, mas também como conformidade entre dois ou mais organismos a serem aproximados ou fundidos, como acontece no caso da compleição e restauro de edifícios antigos. "27

\section{Quattro Libri dell'Architettura}

No Livro I são apresentados os elementos fundamentais do projeto, com enfoque principal no texto, ou seja, nesse primeiro livro, os desenhos são inseridos para ilustrar as ideias expostas.

Junto com os materiais de construção, é nesse primeiro livro que Palladio fala sobre as ordens arquitetônicas e começa a fornecer orientações para o projeto de residências, abordando aspectos de sua compartimentação, construção dos pavimentos e tetos, altura dos quartos, abóbadas, medidas de portas e janelas e também de sua ornamentação, lareiras, escadas e coberturas.

A justaposição de materiais de construção, fundações, muros e outros elementos construtivos, à sistematização das ordens arquitetônicas é um ponto interessante e bastante significativo da obra de Palladio que, assim, deixa claro seu ponto de vista prático, em que os elementos para composição formal e material do edifício têm o mesmo peso, sendo apenas partes para combinação e obtenção do todo. Essa opção paladiana vai de encontro à bipartição do discurso que Alberti apresentou em seu tratado: cinco livros para discutir

\footnotetext{
27 Cf. De Fusco (1992, p.252), tradução da autora, do italiano: "I'Alberti usa la concinnitas non solo come accordo o concerto fra le parti interne d'una data struttura, ma anche come conformità fra due o più organismi da accostare o da fondere, come avviene nel caso del completamento e restauro di antichi edifici."
} 
- aspecto material dos edifícios (firmitas e utilitas) e cinco para discorrer sobre sua ornamentação (venustas).

O Livro II, que versa sobre as construções particulares, é onde aparece a atitude mais inovadora de Palladio em seu tratado, que é o emprego de seus próprios projetos residenciais como modelos ${ }^{28}$ e, graças a isso, "Palladio superou a situação por que haviam sofrido muitas das casas extraurbanas até então: relativamente poucos as viram, e desses ainda menos teriam podido ter a planta ou a organização interna"29.

Entre os diversos projetos apresentados estão as 23 vilas que ele dispõe sem ordem cronológica ou hierárquica, segundo afirma o próprio Palladio: "E nesta parte o leitor será avisado que, ao pôr os ditos desenhos, não respeitei nem graus nem dignidade dos gentis-homens que serão nomeados mas os pus no lugar que considerei melhor, já que todos são honradíssimos." ${ }^{30}$.

Apesar desse discurso, muito provavelmente destinado a agradar seus comitentes, ele faz algumas distinções, como colocar a Villa Capra entre as residências citadinas e dividir os demais proprietários de vilas em dois grupos: o primeiro com os nobres venezianos e o segundo com os gentishomens de terra firme. Na tabela 4 pode-se ver as vilas na ordem em que aparecem com destaque - negrito - para as vilas pertencentes aos proprietários venezianos.

\begin{tabular}{|l|l|l|l|}
\hline \multicolumn{1}{|c|}{ Vila } & \multicolumn{1}{|c|}{ Localidade } & Província & \multicolumn{1}{|c|}{$\begin{array}{c}\text { Data estimada } \\
\text { do projeto }\end{array}$} \\
\hline Villa Capra & Vicenza & Vicenza & $1566-1567$ \\
\hline Villa Pisani & Bagnolo di Lonigo & Vicenza & $1542 * \star$ \\
\hline Villa Badoer & Fratta Polesine & Rovigo & $1554-1555^{*}$ \\
\hline Villa Zeno & Cessalto & Treviso & $1554^{\star}$ \\
\hline Villa Foscari & Gambarare di Mira & Veneza & $1554 *$ \\
\hline
\end{tabular}

\footnotetext{
28 Cf. Lancha (2009, p.xvii).

29 Burns (2012, p.39). Tradução da autora, do italiano: "Palladio superò la situazione di cui avevano sofferto molte delle case extraurbane fino ad allora: le videro relativamente in pochi, e di questi ancora meno avrebbero potuto afferrarne la pianta o la sistemazione degli interni."

${ }_{30}$ Palladio, Livro II, Cap. III (2009, p.72).
} 


\begin{tabular}{|c|c|c|c|}
\hline Villa Barbaro & Maser & Treviso & $1554 * \star$ \\
\hline Villa Pisani & Montagnana & Pádua & $1552 * *$ \\
\hline Villa Cornaro & Piombino Dese & Pádua & 1552 \\
\hline Villa Marocco & $\begin{array}{l}\text { Veneza (Localidade } \\
\text { Marocco) }\end{array}$ & Veneza & $1565 * \star$ \\
\hline Villa Emo & Fanzolo & Treviso & 1556 \\
\hline Villa Saraceno & Finale di Agugliaro & Vicenza & $1548 * \star$ \\
\hline Villa Ragona & $\begin{array}{l}\text { Ghizzolle di } \\
\text { Montegaldella }\end{array}$ & Vicenza & $1553 * \star$ \\
\hline Villa Poiana & Poiana Maggiore & Vicenza & 1549 \\
\hline Villa Valmarana & Monticello Conte Otto & Vicenza & 1542 \\
\hline Villa Trissino & Meledo di Sarego & Vicenza & $1553 * \star$ e 1567 \\
\hline Villa Repeta & Campiglia dei Berici & Vicenza & $1560 *$ \\
\hline Villa Thiene & $\begin{array}{l}\text { Cicogna di } \\
\text { Villafranca Padovana }\end{array}$ & Padova & 1556 \\
\hline Villa Angarano & Bassano del Grappa & Vicenza & 1548 \\
\hline Villa Thiene & Quinto Vicentino & Vicenza & $1542 *$ \\
\hline Villa Godi & $\begin{array}{l}\text { Lonedo di Lugo } \\
\text { Vicentino }\end{array}$ & Vicenza & 1537 \\
\hline Villa Sarego & $\begin{array}{l}\text { Santa Sofia di } \\
\text { Pedemonte }\end{array}$ & Vicenza & 1565 \\
\hline Villa Sarego & $\begin{array}{l}\text { Miega di Cologna } \\
\text { Veneta }\end{array}$ & Verona & 1562 \\
\hline Villa Mocenico & Dolo & Veneza & 1554 * \\
\hline
\end{tabular}

Tabela 4 - Vilas apresentadas no tratado na ordem definida por Palladio.

* data estimada; ** cerca de ${ }^{31}$ Fonte: Adaptado de Puppi (1999).

31 As datas foram obtidas no Cisapalladio, e estão disponíveis em: $<$ http://http://mediatecapalladiomuseum.org/palladio/opere.php?tipologia=7\&S= $\mathrm{C} \& \mathrm{SD}=\mathrm{A} \& \mathrm{~V}=1 \& \mathrm{RN}=12 \& \mathrm{TR}=33 \& \mathrm{P}=1>$, acesso em 09/04/2014. 
LA SEGV ENTE fabrica c̀ appteffolapotza di Montagnana Caffello del Padoano, c fueti. ficata dal Magnifico Signot Francefco Pifani : i iquale pafflato amiglior uita non la hapotuto finite. Le ftanze mag gioni fono lunghe un quadro e tre quarti : iuolti fono a fchiffo, alti iccondo il fecoed ms lo delle altezze de' uolti le mediocri fono quadre, \& intuoltarc a cadino : I camerini,el'andito h no di wasle larghezza : i wolti loro fono alti due quadri : L a entraxa ha quatro colonne, il cuinto pu

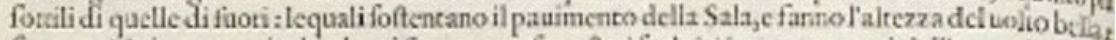
fecura. Ne iquattro nicchi,che ui fi ueggono fono ftati feolpiti i quattro tempi dell'anno da Meffs Alelfandto Vitcoria Sculeore eccellente: il primo ordine delle colonne è Dorico, ilfecondo Iocion Leflanze di foj:a fono in folaro: L'altezza della Salagiugne fin fotto il tetto. Haqueftafabricz dus ftrade dat fianc $x$, doue fono due porte, fopta le quali uifono anditi, che conducono in cuciaz, 6 luoghiper feruitoti.

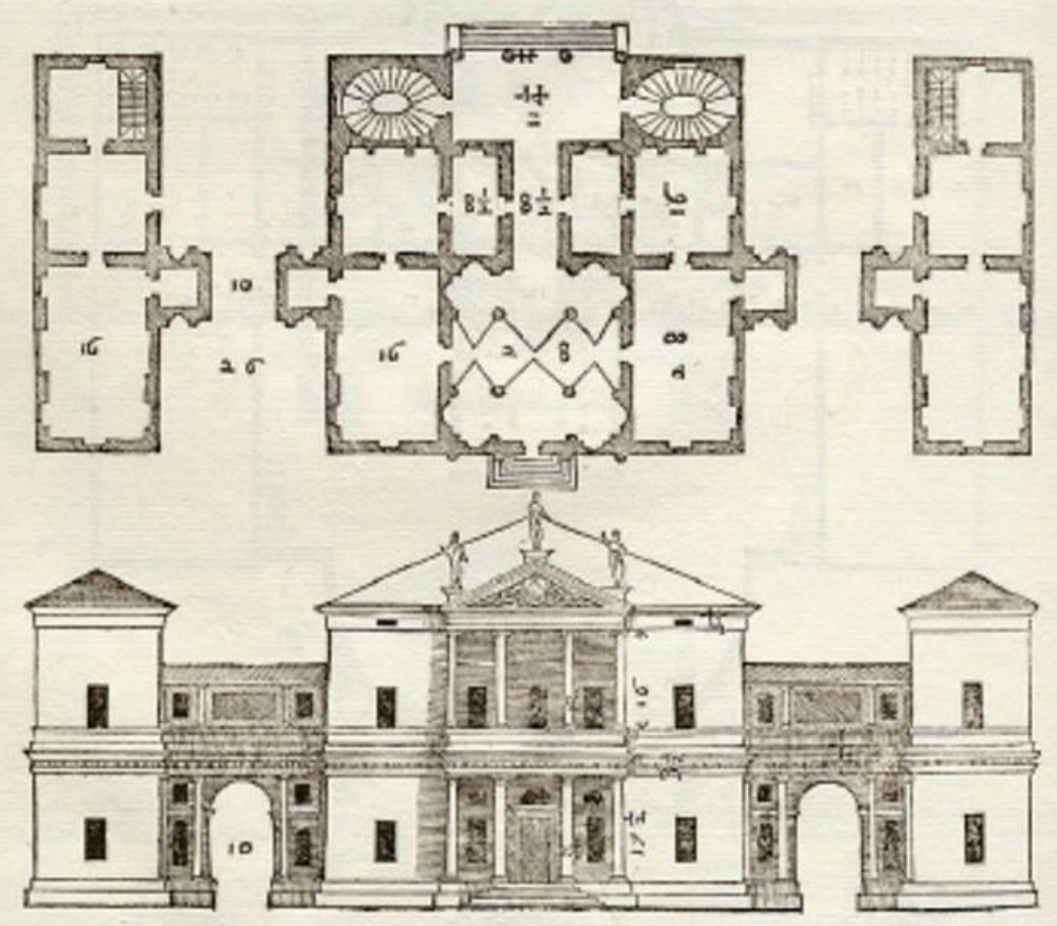

LA FABRICA

Figura 13 - Página onde é apresentado o projeto da Villa Pisani, Montagnana, no Livro II. Fonte: Palladio Livro II, Cap. XIIII (1570, p.51). 
Percebe-se que Palladio retoma nesse livro a opção desenvolvida por serlio, ao transformar o desenho na ferramenta primordial para comunicação de seus projetos, com um pequeno texto contendo informações relacionadas a comitentes, localização, implantação no terreno, outros artistas que tenham participado da construção, ou mesmo ao próprio edifício, mas que não possam ser percebidas por meio dos desenhos. Na Figura 13 pode-se ver um exemplo dessa prática em uma reprodução da página do tratado onde é apresentada a Villa Pisani Montagnana.

Na exposição dos projetos, Palladio lança mão de seu processo projetual, onde o todo é obtido a partir da combinação de peças e elementos, com manipulação das suas proporções ${ }^{32}$. O próprio tratado parece ter sido composto segundo esse método: ele seria o todo, cujas partes - os projetos apresentados por Palladio - são revistas e redesenhadas, de forma a se relacionarem melhor com o conjunto.

O tratado, portanto, aparece sujeito aos princípios compositivos que ele emprega na elaboração de seus projetos arquitetônicos, o que se confirma pela sequência dos projetos apresentados nesse livro, que ele afirma ter colocado na ordem que lhe pareceu mais conveniente.

No livro III, Palladio apresenta seus próprios projetos para obras públicas, mas com organização das pranchas similar à do primeiro: o texto como elemento principal e as imagens utilizadas para ilustrá-lo.

No livro IV, são apresentados os desenhos dos edifícios que Palladio visitou em suas viagens de estudos. Assim como no II, o enfoque principal está sobre os desenhos, mas aqui eles possuem uma apresentação menos sistematizada, aproximando daquela encontrada no Livro I.

\section{Definições de vila}

Ainda que o foco desse trabalho esteja nas casas patronais das vilas, é importante determinar como os dois autores definiram o termo vila, e como a específica residência do proprietário era enquadrada nessas definições. Acredita-se que as definições apresentadas tanto por Alberti quanto por Palladio estiveram sempre relacionadas com a época e $\circ$ local em que foram produzidas. Na antiguidade a

${ }^{32}$ Cf. Lancha $(2006$, p.87). 
residência na cidade era chamada villa urbana, para ser distinguida da villa rustica, que era a residência campestre ${ }^{33}$.

Como foi apontado no capítulo 3, Alberti apresentou diferentes definições de vila em suas diferentes obras, sempre compreendendo produção agrícola e deleite, o que variou de uma obra para outra foi o peso atribuído a cada um deles.

A obra de Alberti marcou o início da produção das vilas, na primeira metade do século XV, e esteve sempre fortemente relacionada ao ambiente econômico e cultural florentino do período e, principalmente, à família Médici. Inicialmente a vila albertiana se aproxima da definição antiga, quando, em I Libri della Famiglia (1434), ela é citada como uma residência secundária dos proprietários, habitantes da cidade: "uma residência concebida como simples deleite, entendida antes de tudo como local de retiro e repouso (ainda que alguns cultivos possam ser promovidos como parte do deleite) cuja construção e cuja manutenção dependam do capital excedente das atividades urbanas do proprietário. "34. Essa aproximação provavelmente ocorre porque a literatura romana antiga alimentava a literatura renascentista em diversas áreas, o que se verificou também no caso das vilas ${ }^{35}$.

Nesse livro é feita uma diferenciação entre a propriedade destinada à produção agrícola, chamada terra, e a vila. A terra deveria ser apta a produzir diversos tipos de culturas e animais: "Encontrarei modo de ter uma propriedade que por si só, com menor despesa que comprando na praça, fosse adequada a abastecer-me a casa de cereais, vinho, lenha, palha e outras coisas assim, e onde criarei rebanhos, pombos, frango e ainda peixes." ${ }^{36}$.

\footnotetext{
33 Ackerman (1992, p.36).

34 Ackerman (1992, p.11). Tradução da autora, do italiano: "una dimora concepita uper semplice diletto», intesa prima di tutto come luogo di ritiro e riposo (sebbene alcune coltivazioni possano essere promosse come parte del «diletto») la cui costruzione e il cui mantenimento dipendono da eccedenze di capitale derivate al proprietario dalle sue attività urbane. L'ideologia che esalta la campagna e disdegna la città è quindi, in parte, una reazione paradossale alla dipendenza dello stile della villa di campagna dalle risorse economiche della città".

35 Esse tema foi desenvolvido no início do capítulo 3.

36 Alberti (1994, p.206). Tradução da autora, do italiano: "Darei io modo d'avere la possessione la quale per sé con molto minore spesa che comperandole in piazza fusse atta a tenermi la casa fornita di biave, vino,
} 
Sobre a vila são feitas recomendações de caráter ideológico, retomando várias vezes o argumento de que a vila é um lugar purificador de todo o mal com que se convive na cidade - tanto física quanto mentalmente, e de caráter prático, quanto à escolha do lugar onde implantá-la: agradável, com ar puro, belas paisagens, águas, bons ventos, e não muito distante das terras, para que seu proprietário possa ir até lá diariamente e colher frutas e ervas ${ }^{37}$.

Já no pequeno Villa (cerca de 1440), Alberti parece inverter a relação de prioridades que predominava no livro anterior. A propriedade, que lá era chamada de terra, aqui passa a ser chamada de vila, enquanto o que lá se entendia por vila, aqui passa a ser chamado de casa. A vila nesse texto é a propriedade rural, independentemente de qual fosse sua finalidade. Ela poderia contemplar as terras para cultivo e a residência patronal, ou somente uma das duas: "A casa faz menos falta à propriedade que as terras à casa. A vila será ótima quando demandará esforço e não despesa." ${ }^{38}$.

Percebe-se, na continuação do texto, que a produção não somente está associada à vila, mas é sua prioridade: "E seja a vila não como uma casa afastada da praça, de modo que precises comprar tudo do mercado para abastecê-la, mas seja tal que, exceto pelo sal, possivelmente tenhas excedente de cada coisa que possa ser vendida no mercado."39. A preocupação com a produtividade permeia todo o texto e Alberti, que apresenta inúmeras recomendações a fim de maximizá-la, desde a escolha da propriedade até o manejo da terra e o trato com servos e animais.

No De re aedificatoria, concluído cerca de dez anos mais tarde (1452), o termo vila recebe uma definição mais madura, representando agora toda a propriedade, enquanto as residências dessas propriedades são subdivididas em: case di villa - destinadas às famílias camponesas, case de Padroni ou ville signorili - habitadas pelas pessoas de condição livre.

De acordo com Ackerman ${ }^{40} \circ$ que distingue essas duas casas de vila albertianas é o elemento prazer. Para o autor

\footnotetext{
legne, strame e simili cose, ove farei alevarvi suso pecugli, colombi e polli, ancora e pesce."

37 Alberti (1994, p.209).

38 Cf. Alberti (2011b, p. 2). Ver Anexo I, onde consta a tradução desse texto.

39 Alberti (2011b, p.2).

40 Ackerman (1992, p.3). Tradução nossa, do italiano: "La casa colonica tende a essere semplice nella struttura e a conservare forme inveteratamente
} 
"A casa camponesa tende a ser simples na estrutura e a conservar formas inveteradamente tradicionais, que não implicam na intervenção de um projetista. Ao contrário disso, a vila é o produto típico da capacidade criativa de um arquiteto e documenta a modernidade."

É importante observar que nesse momento Alberti relaciona as casas das famílias camponesas à servidão, pois senhores feudais ainda dividiam os campos toscanos com cidadãos livres. Essas residências aparecem associadas à utilidade e ao lucro, e têm como atribuição a produção, a colheita e o armazenamento dos frutos de suas terras. Por sua vez, as casas senhoriais, habitadas por pessoas de condição livre, são relacionadas ao deleite e prazer do espírito ${ }^{41}$.

Enquanto no primeiro texto o foco da vila é o deleite e no segundo a produção ganha ênfase, no terceiro as duas versões da vila são colocadas lado a lado, com destaque para suas diferenças. Isso reflete a mudança no perfil dos proprietários de terras que acontecia nesse momento. No início o ideal de vida na vila remontava à antiguidade clássica e sua busca pelo deleite, mas no decorrer do século XV a proliferação das vilas esteve estreitamente ligada à busca de diversificação dos investimentos pelos burgueses. Além disso, a produção de arquitetura nas vilas, sem os limites existentes nas cidades, permitia uma maior liberdade compositiva e o uso da expressão artística como símbolo de poder. A mudança na definição albertiana de vila percebida nesses três textos provavelmente acompanhou essa mudança social mais ampla, buscando sempre compreender e demonstrar o papel da arquitetura nesses diferentes momentos.

Da mesma forma, a definição de vila de Palladio, ao fazer referência a toda propriedade está associada à tradição vêneta em que a produção era premissa básica da existência de uma vila. Palladio, em seu tratado, após tratar das casas da

\footnotetext{
tradizionali che non implicano l'intervento di un progettista. La villa è invece il prodotto tipico della capacità creativa di un architetto e ne documenta la modernità."

$41 \mathrm{Na}$ versão italiana, essa vila é associada à rappresentanza, ou representação, enquanto demonstração de poder. Apesar da manifestação do poder e das classes sociais por meio da arquitetura ser retomada em vários pontos do tratado de Alberti, acredita-se que na versão original ela não aparece nesse momento. Foi feita a opção pela definição convergente encontrada nas versões portuguesa e a florentina, ambas traduzidas do latim por grandes conhecedores desse idioma, respectivamente 'prazer do espírito' e 'diletto dell'animo'.
} 
cidade, passa a discutir as vilas, descrevendo-as da seguinte maneira:

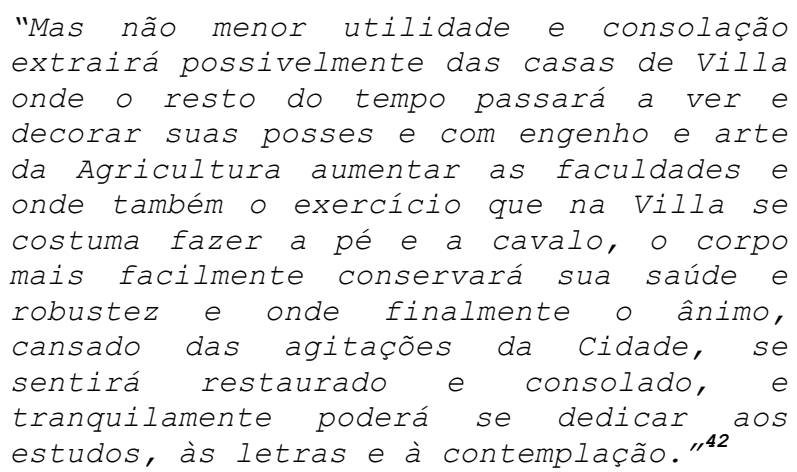

Pode-se perceber, em primeiro lugar, que a vila paladiana é, portanto, toda a propriedade rural e, em segundo lugar, que ela funde as diferentes definições albertianas em uma só, onde a produção, o lucro, a prática de exercícios físicos e o deleite e a contemplação aparecem lado a lado.

Conceitualmente, a definição de vila no tratado de Palladio se aproxima do terceiro e mais maduro modelo de vila descrito por Alberti: ambos entendem como vila a propriedade rural e como casa di villa a edificação destinada à moradia de seu proprietário. Entretanto, enquanto Alberti separa a residência patronal daquela dos servos, Palladio faz essa separação no interior de um mesmo edifício, ou de dois ou mais edifícios interligados por loggie, como será demonstrado a seguir.

\section{Escolha do lugar}

Sobre a escolha do lugar onde se construir as vilas, tanto Alberti quanto Palladio fazem recomendações em seus tratados, mas Alberti, também o faz em seu texto Villa, onde fornece critérios para escolha da propriedade rural. Os critérios apresentados pelos dois autores são bastante semelhantes e em alguns momentos até complementares.

No tratado o assunto é iniciado no Livro I, Cap. III, quando Alberti fala da escolha da região ${ }^{43}$. Logo no início ele se reporta aos antigos, quanto à importância do clima:

\footnotetext{
42 Palladio, Livro II, Cap. XII (2009, p.113).

43 De acordo com Krüger (Alberti, 2011a, p.148), o termo latino regio, aqui traduzido por região, é mutável no decorrer do tratado, mas no contexto desse capítulo pode ser entendido como "porção de território relacionado, de
} 


\begin{abstract}
"E, antes de mais, procuravam a todo o custo evitar terem clima pesado e prejudicial: precaução sábia e absolutamente indispensável. Admitem, na verdade que o terreno e a água, se porventura tiverem algo de mal, podem ser corrigidos graças à técnica e ao engenho, ao passo que o clima, segundo afirmam, não pode emendar-se nem com o recurso do engenho nem com a força do homem."
\end{abstract}

A mesma menção à capacidade humana de transformar o campo é percebida em Villa, quando Alberti explica que os critérios mais importantes a se observar e a dissuadir o interessado em adquirir uma determinada propriedade são aqueles que não podem ser alterados, e coloca entre eles o clima: "A terra tu podes corrigir, de aquosa torná-la seca, se é pobre em nutrientes podes adubá-la, mas nunca modificarás o céu. "45

A afirmação de que, com engenho e técnica, é possível corrigir diversos problemas do ambiente parece expressar o ideal de natureza dominada pelo homem que ganhava espaço e que, mais tarde, encontrou grande expressão no projeto renascentista de jardins nos palácios e nas próprias vilas.

Outro ponto discutido por Alberti no Cap. III é a presença de rios. Se, por um lado, quando Alberti ressalta a importância da presença de água nas proximidades quando faz suas recomendações para que a vila seja construída "no meio do campo, junto do sopé de um monte, numa zona com água. "46.

Por outro, ele pede atenção ao tipo de água, já que nem todas são saudáveis:

\begin{abstract}
"Dizem os ruralistas que todo o rio que engrossa com o degelo traz consigo um ar frio e denso. Mas, de todas as águas, nenhuma é mais infecta do que aquela que fica inquinada por não ser mexida por nenhuma espécie de movimento. E será tanto mais doentio o contágio da sua proximidade quanto menos é renovada por acção dos ventos salubres". ${ }^{47}$
\end{abstract}

forma abrangente, com o clima, o terreno, o ar e a água, com implicações sobre a qualidade de vida do homem."

${ }^{44}$ Cf. Alberti, Livro I, Cap. III (2011a, p.148).

45 Cf. Alberti (2011b, p.2). Tradução nossa, do italiano.

${ }^{46}$ Cf. Alberti, Livro V, Cap. XIV (2011a, p.353).

47 Cf. Alberti (2011a, p.151-152). 
Essa menção às áreas alagadiças poderia ser uma explicação para o trecho de Villa onde o autor se limita a advertir: "Será mal localizado aquele campo ao qual o rio esteja de frente" ${ }^{48}$. Tendo em vista que Alberti iniciou sua literatura sobre as vilas falando sobre as propriedades situadas no entorno de Florença, essa recomendação de evitar proximidade com o rio poderia ser originada pelas cheias do rio Arno, com consequente alagamento de suas margens e formação de áreas pantanosas ${ }^{49}$.

Palladio, por sua vez, também recomenda a implantação das vilas nas proximidades de rios:

"Se se puder construir sobre o rio, será
muito cômodo e belo; por isso, a colheita
com pouco custo em todo o tempo se poderá
conduzir com barcos a Cidade, e servirá
aos usos da casa e dos animais, além de
proporcionar muito frescor no Verão e
belíssima vista, e com enorme utilidade e
ornamento se poderão aguar as posses, os
Jardins e os Pomares, que são a alma e o
deleite da Villa. Mas não podendo ter
rios navegáveis, se procurará construir
perto de outras águas correntes,
afastando-se sobretudo das águas mortas e
que não correm porque produzem muito mau
cheiro, (...) de modo que não se sinta o
desconforto dos Pernilongos e de outros
insetos que nascem da putrefação das
águas mortas e pantanosas." 50

Percebe-se que Palladio se aproxima da argumentação de Alberti quanto às águas correntes, ao mesmo tempo que extrapola as finalidades de seu antecessor ao colocar o rio como meio de acesso à propriedade e, portanto, de escoamento da produção. No Vêneto, o transporte fluvial era largamente utilizado nesse período, tanto para pessoas quanto para mercadorias, especialmente sendo Veneza um importante centro de comércio marítimo.

Já na Toscana de Alberti predominava o transporte por via terrestre, o que o levou a fazer recomendações quanto à localização da propriedade, aconselhando que elas não estivessem muito distantes da cidade, para que fosse possível

\footnotetext{
48 Cf. Alberti (2011b, p.1). Tradução nossa, do italiano.

49 Também não se ignora a possibilidade de que essa seja uma recomendação supersticiosa, podendo ser originária dos antigos tratados agronômicos romanos ou mesmo de hábitos locais da época. Sobre as práticas agrícolas, de forma geral, seria interessante confrontar com o texto de Columella.

50 Cf. Palladio, Livro II, Cap. XII (2009, p.113).
} 
ir a pé e voltar a cavalo, como recomendava Xenofonte ${ }^{51}$ para a prática de exercícios. Para que isso fosse possível, além da distância adequada, a vila albertiana deveria se beneficiar de uma via de acesso "apta e muito cômoda para viagens e transportes de cargas, de Inverno e Verão (...); e será bom se tal via não passar por uma porta da cidade distante, e sim por uma próxima" ${ }^{52}$.

Por outro lado, ainda que não seja distante da cidade ela também não deveria ser excessivamente próxima, evitando lugares muito concorridos como vias militares ou portos onde atraquem muitas embarcações para que "o patrimônio familiar não seja dilapidado pela frequência de hóspedes de passagem." 53. A preocupação de Alberti com o patrimônio familiar e com a lucratividade da vila, que aqui fica evidente, é constante em suas três obras que abordam o tema, - que provavelmente está associado às dificuldades financeiras que ele mesmo enfrentou à época da morte de seu pai.

Da mesma forma que desaconselha as áreas onde se encontra água sem movimento, Alberti também desaconselha locais onde o ar é imóvel: "Como diz Ovídio, 'As águas corrompem-se se ficarem estagnadas'. E o ar? Não há dúvida de que o movimento the confere grande vivacidade." ${ }^{54}$. Alberti destaca, entretanto, que nem todos os ventos são desejáveis, mas deve-se evitar o Austro e o Coro, que provocam constipações e tosse ${ }^{55}$, respectivamente, e também os ventos das embocaduras de vales: "com efeito, aí os ventos são demasiado frios se passaram pela sombra, ou demasiado escaldantes quando passaram por uma planície banhada por sol intenso. " 56

No mesmo trecho em que Palladio fala sobre a importância das águas serem correntes para evitar mau cheiro, ele também fala sobre os ventos, dando instruções para se verificar a salubridade do ar: "darão indícios os edifícios antigos, se não estiverem corroídos e estragados; se as árvores estiverem bem nutridas, belas, não curvas de um lado

\footnotetext{
51 Cf. Xenofonte, Oecon, 2, p.15-8, apud, Alberti, Livro V, Cap. XIV (2011a, p. 354$)$.

52 Cf. Alberti, Livro V, Cap. XIV (2011a, p.354).

53 Cf. Alberti, Livro V, Cap. XIV (2011a, p.354).

54 Cf. Alberti, Livro I, Cap. IV (2011a, p.153).

55 Alberti cita as obras de Plínio o Antigo, Teofrasto e Hipócrates sobre a ação dos ventos na saúde. Cf. Livro I, Cap. III (2011a, p.152).

${ }^{56}$ Cf. Alberti, Livro V, Cap. XV (2011a, p. 355).
} 
pela ação dos ventos e não forem das que nascem em lugares pantanosos.". E também como Alberti ele recomende que se evitem os vales fechados entre as montanhas:

"porque os edifícios escondidos entre os
Vales, além de serem privados de poder
avistar longe, e de serem vistos e não
terem dignidade e majestade alguma, são
totalmente contrários a saúde porque
pelas chuvas que aí se dão, a terra
impregnada exala vapores pestiferos
(...). Além disso, se o Sol entrar pelo
reflexo dos raios, haverá calor excessivo
e, se não entrar, por causa da sombra
continua as pessoas ficarão como parvase
de cor ruim. Os ventos, ainda que entrem
nesses ditos vales, como em canais
estreitos, causarão demasiado furor, e se
não soprarem, o ar aí abafado ficará
denso e malsão." 57 an

Enquanto Alberti aconselha como localização ótima da vila que ela seja posicionada no sopé de um monte, ainda falando sobre os ventos, Palladio também recomenda a escolha de lugares altos e aprazíveis "onde o ar seja continuamente movido por ventos e a terra pela caída seja dos vapores úmidos e ruins purgada, de modo que os moradores se conservem sãos e alegres e com boa cor"158.

Sobre a vizinhança, no tratado Alberti se limita à afirmação que abre o Capítulo III, ainda no Livro II: "Voltando à escolha da região, convirá que ela seja tal que, sob todos os aspectos, os habitantes se venham a sentir bem com as condições naturais e com o gênero e trato dos vizinhos." 59 . Dessa vez é em Villa que Alberti faz observações um pouco mais específicas sobre o argumento: "Comprada a vila, primeiramente cuide para que teus vizinhos te queiram tanto bem quanto se querem os teus parentes. Os amigos estarão prontos para te ajudar muito antes dos parentes. E onde tens um vizinho amigo, podes dizer que lá também estás." $"$.

Essas referências à amizade e à vizinhança eram recorrentes entre os autores da época, fossem eles moralistas ou não: "Os moralistas e memorialistas insistem de bom grado na necessidade e nas vantagens da coisa. A amizade é um

\footnotetext{
57 Cf. Palladio Livro II, Cap. XII (2009, p.113-114).

58 Cf. Palladio Livro II, Cap. XII (2009, p.113).

59 Cf. Alberti, Livro I, Cap. IV (2011a, p.153).

${ }^{60}$ Cf. Alberti (2011b, p.2). Tradução nossa, do italiano.
} 
grande bem em si. Os humanistas, seduzidos pelos grandes exemplos da Antiguidade, falam dela com fervor."61

O argumento da vizinhança não é mencionado no tratado de Palladio, mas em todo o conjunto das recomendações, percebe-se uma grande proximidade na argumentação dos dois autores. Até mesmo pela semelhança de muitas justificativas, algumas mais desenvolvidos em Alberti e outros em Palladio, os dois textos parecem complementares quanto à escolha do lugar para as vilas.

\section{Processo de projeto e Representação gráfica na arquitetura}

A forma como Alberti se refere ao desenho no Livro I (delineamento), sugere toda a concepção do edifício e não apenas sua representação gráfica. Para ele, os desenhos são "o traço constitutivo da forma, as linhas essenciais da ideia (...) eles não representam só a primeira etapa do projeto, mas a sua lógica." 62

Por meio do desenho é que podem ser encontradas as constantes formais, cuja busca era tão importante no Renascimento: "é função específica do delineamento prescrever aos edifícios e às suas partes uma localização adequada e proporção exacta, uma escala conveniente e uma distribuição agradável." ${ }^{63}$. Krüger ${ }^{64}$ aponta a correspondência entre os termos em destaque no trecho anterior e os conceitos collocatio, numerus e finitio - respectivamente, que contribuem para a concinnitas da obra toda.

A partir desse discurso, ele desenvolve a argumentação acerca da independência entre desenho e matéria, uma premissa fundamental na busca da intelectualidade no processo de trabalho do arquiteto:

"E será legítimo projectar mentalmente
todas as formas, independentemente de
qualquer matéria. (...) Assim sendo,
segue-se que o delineamento será um
traçado exacto e uniforme, mentalmente
concebido, constituido por linhas e

\footnotetext{
${ }^{61}$ La Ronciére (2009, p.172).

${ }^{62} \mathrm{Na}$ versão em italiano (Alberti, 2010), Giontella (2010, p.11) explica que, ao traduzir o texto do latim, a melhor significação para 'lineamenta' foi encontrada no termo 'lineamenti' e não no termo 'disegno'. Segundo a autora, "Iineamenti' estaria mais próximo de corresponder à lógica albertiana e à estrutura da obra. Na versão portuguesa, o termo foi traduzido do latim como delineamento.

63 Alberti, Livro I, Cap. I (2011a, p.145).

${ }^{64}$ Cf. Krüger (2010, p.146).
} 
Nesse primeiro livro, ao mesmo tempo em que discute cada um dos seis temas que, para ele, compõem a arte de construir, Alberti apresenta noções gerais de geometria e composição dos edifícios a partir de linhas curvas e retas. o discurso tem como base edifícios e autores antigos, como Demócrito ${ }^{66}$, e descreve as relações entre ângulos, curvas e círculos, mas extrapola os limites da antiguidade com a proposição de novas diretrizes, como a variedade (varietà):

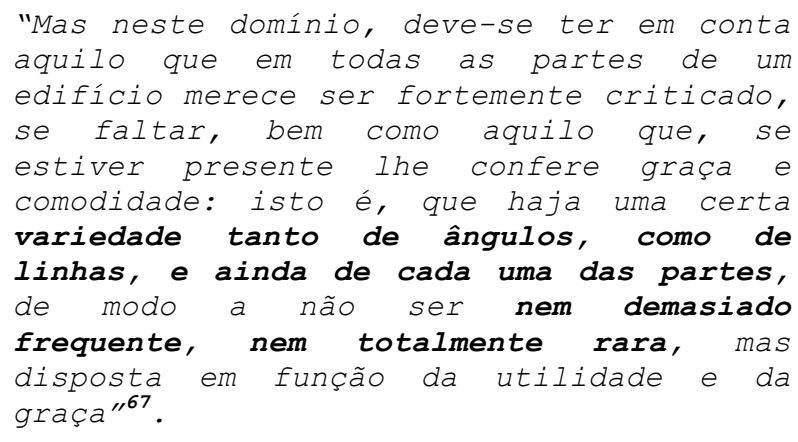

Ele começa falando da variedade de linhas e ângulos, de que são compostas as diferentes partes dos edifícios, até que passa a falar também da variedade das próprias partes, que devem ser definidas por diferentes tipos de linhas: "Não gostaria que todos os elementos fossem desenhados apenas segundo um único traçado e uma só definição de linhas."68.

Mesmo escrevendo tanto e tão detalhadamente sobre o desenho, a opção de Alberti por não ilustrar seu tratado também pode falar sobre a intelectualidade da representação gráfica para ele. Embora Alberti afirme não ter inserido ilustrações no tratado para evitar distorções decorrentes do processo manual de cópia. De certa forma, ao fazer isso ele coloca desenho e texto no mesmo patamar, ao utilizar o texto para falar sobre o ato de desenhar e sobre como utilizar a representação gráfica no projeto, com descrições de formas detalhadas e precisas.

$\mathrm{Na}$ tentativa de demonstrar essa intelectualidade da arquitetura, ele emprega conceitos de áreas que já eram

\footnotetext{
65 Alberti, Livro I, Cap. I (2011a, p.146). Grifo nosso.

${ }^{66} \mathrm{Cf}$. De Fusco (2003, p.123) faz referência à citação de Demócrito para recuperar a máxima de que arquitetos e matemáticos se serviam para a quadratura do círculo.

67 Alberti, Livro I, Cap. IX (2011a, p.165). Grifo nosso.

68 Alberti, Livro I, Cap. IX (2011a, p.172).
} 
incluídas no quadrivium, como a música, a geometria e a aritmética: É interessante observar a menção que Alberti faz à música - destacada no trecho abaixo - ainda nesse primeiro livro, em que fala sobre o processo intelectual de composição arquitetônica.

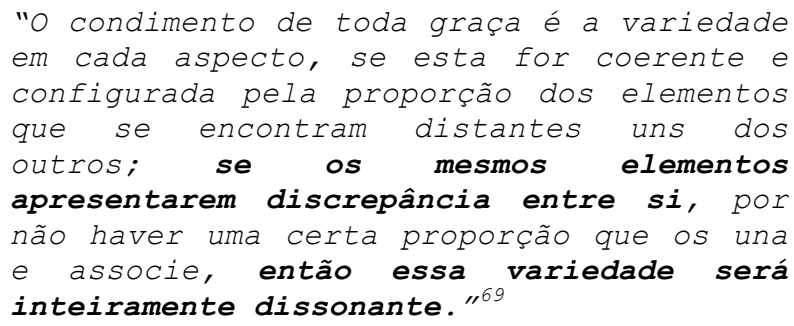

A questão da variedade é retomada novamente por Alberti no Livro II (cap.I), no Livro IV (cap. I e III) e no Livro IX (IV), demonstrando a importância do tema no tratado.

Da mesma forma, para Palladio a variedade é um tema muito importante, de que ele fala no capítulo do Livro I que dedica aos Abusos:

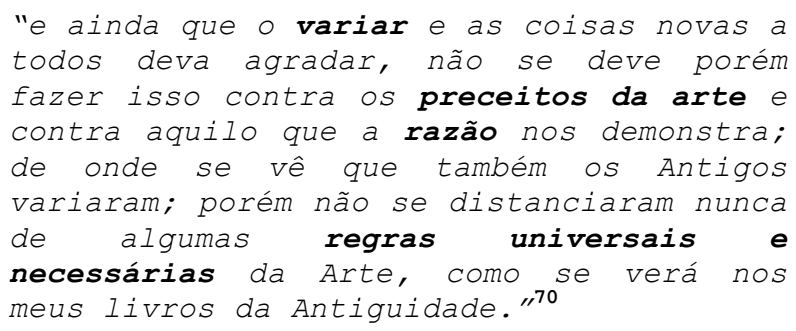

- programa das vilas projetadas por Palladio é bastante homogêneo, assim como é relativamente homogêneo o conjunto de seus comitentes. Como observa Lancha ${ }^{71}$, as variações apresentadas por Palladio em seus projetos para as vilas estão associadas ao volume de recursos financeiros de seu proprietário, ao tamanho da propriedade e à existência ou não de produção agrícola. É possível identificar alguns tipos entre as vilas e agrupá-las a partir dessas afinidades, porém, o que se verifica é que, todas elas apresentam quase tantas diferenças quanto semelhanças, evidenciando ainda mais a capacidade criativa de Palladio.

\footnotetext{
69 Alberti, Livro I, Cap. IX (2011a, p.172). Grifo nosso.

70 Palladio, Livro I, Cap. XX (2009, p.72). Grifo nosso.

71 Cf. Lancha (2010, p.221).
} 
Para Tafuri ${ }^{72}$, na composição de suas casas de vila, Palladio promove ciclos de arquitetura, que podem ser definidos como autênticos temas com variações.

Nas pranchas em que ele apresenta seus projetos de vilas são utilizadas as projeções ortogonais, recomendadas por Alberti. Mais que representações dos projetos, elas são reconsiderações posteriores com finalidade explicativa desses projeto ${ }^{73}$. Essa representação gráfica com projeções ortogonais somada ao uso da xilogravura - que não permite extremo detalhamento - colabora para exaltar o método compositivo de Palladio:

"Fundado sobre a habilissima combinação
de poucos sinais arquitetônicos
carregados de classicismo, como loggie,
frontóes, colunas, edículas, pórticos
trabeados, declináveis com caleidoscópica
variedade, racionalmente ordenados por
plantas e fachadas harmoniosamente
simétricas, o método divulgado por
Palladio chega a formulaços de caráter
álico e monumental, frequentemente
apesar de dimensões contidas e de uma
essencialidade 74
'minimalista'."74 verbal

No Livro II, Alberti também faz uma importante consideração a respeito do papel e da responsabilidade do arquiteto, ao afirmar que somente os mais experientes nessa disciplina são capazes de projetar e predeterminar cada parte do edifício, de forma a evitar que no decorrer da obra ou mesmo depois que ela estiver completa seja percebido que ela precisa de correções. É, portanto, obrigação do arquiteto observar cuidadosa e racionalmente o programa e o planejamento do projeto, a fim de evitar arrependimentos posteriores. De Fusco ${ }^{75}$ afirma que esse projeto de que fala Alberti não diz respeito somente ao ato de desenhar, mas ao processo projetual, com a preparação de modelos, busca de conselhos e pareceres, em uma previsão e experimentação que

\footnotetext{
72 TAFURI, M. Teorie e Storia dell'architettura. p.144. apud, Martinez (2000, p.113).

73 Cf. Visentini (1995, p.251).

74 Battilotti (2011, p.7-8). Tradução da autora, do italiano: "Fondato sull'abilissima combinazione di pochi segni architettonici gravidi di classicità, quali logge, frontoni, colonne, edicole, portici trabeati, declinabili con caleidoscopica varietà, razionalmente ordinati da piante e facciate armoniosamente simmetriche, il metodo divulgato da Palladio approda a formulazioni di carattere aulico e monumentale, spesso a dispetto di dimensioni contenute e di una essenzialità verbale quasi 'minimalista'."

${ }^{75}$ Cf. De Fusco (2003, p.129).
} 
parecem unir a fase projetual e a construtiva, aludindo a uma unidade no processo arquitetônico. O planejamento seria a fase prioritária e mais rica de propósitos e intenções nesse processo e, sobretudo, a mais apropriada para se modificar e corrigir defeitos que posteriormente seriam irremediáveis.

Alberti fala sobre a importância da construção de modelos no processo de projeto, pois, por meio deles é que se poderia quantificar os materiais necessários para se levar a cabo a construção do edifício. Além disso, ele explica que, com essa finalidade, os modelos não deveriam ser muito delicados, pois deveriam expressar mais o engenho do inventor que a habilidade manual do mestre. O mesmo vale para a representação gráfica, que deve se distanciar das ilusões empregadas pelos pintores - como sombreamentos, linhas e ângulos distorcidos - obtendo a perspectiva a partir da planta e apresentando as projeções ortogonais das fachadas com linhas constantes e ângulos invariáveis. Para o autor, dessa forma a obra será julgada por suas medidas e razões precisas, e não pelo que ela aparenta.

Essa posição albertiana é associada por Borissavlievitch ${ }^{76}$ ao conceito que Platão faz da arquitetura: ao contrário das demais artes, a arquitetura não é a aparência das coisas, mas as próprias coisas. O arquiteto faz um edifício real enquanto o pintor somente o representa. Então, retomando Platão, para Alberti, desenhos e modelos nas artes figurativas têm autonomia artística e são obras de mestres, enquanto na arquitetura têm uma acentuada razão prática designando outras coisas e são obras de inventores. De Fusco ${ }^{77}$, por sua vez, complementa essa argumentação, falando da representação arquitetônica como uma metalinguagem, para a qual a própria arquitetura seria a linguagem.

Confrontando essa posição albertiana com os desenhos encontrados nos Quattro Libri, percebe-se que Palladio emprega dois tipos de representação, um que se aproxima dos preceitos albertianos e outro que dele se afasta.

Nos três primeiros livros - onde Palladio apresenta instruções para o projeto e a construção dos mais diversos edifícios - predominam as projeções ortogonais e o que

\footnotetext{
76 Cf. Borissavlievitch, M. Les théories de I'architecture. Payot: Paris, 1926, p.1-2, apud De Fusco (2003, p.130).

${ }^{77}$ Cf. De Fusco (2003, p.131).
} 
Alberti entendia como sendo a representação arquitetônica, sem sombreamentos e outros efeitos que pudessem confundir a visão do leitor ou impedir a leitura das medidas anotadas. Nesse ensejo, em muitos desenhos a representação chega a ser quase esquemática.

Já no quarto livro aparecem ilustrações de edifícios antigos, muitos dos quais ele visitou em suas viagens e alguns que possivelmente copiou de cadernos de outros arquitetos. Aqui os desenhos são apresentados de forma aglomerada, com algumas cotas indicando as medidas principais dos edifícios, assemelhando-se bastante a um caderno de desenhos, como pode-se perceber a partir das Figuras 14 e $\mathbf{1 5}$ onde se tem, respectivamente, uma página do Taccuino Senese, de Giuliano da Sangallo e uma página do livro IV de Palladio.

Nesse livro, ao contrário do que acontece nos anteriores, a representação predominante dos edifícios é muito mais ricamente detalhada, com sombreamentos e efeitos que fazem parecer que os edifícios e elementos estão em perspectiva, ainda que também sejam representados em projeções ortogonais. Nas Figuras 16 e 17 pode-se ver a diferença entre a representação utilizada para dois capitéis coríntios com entablamento bastante semelhante, sendo 0 primeiro deles encontrado no livro I e o outro no livro IV.

Embora sejam muito semelhantes, os dois desenhos se diferem principalmente pelo modo como são apresentados. Ambos os desenhos apresentam riqueza de detalhes, mas o segundo faz uso de linhas para compor o efeito de sombreamento e profundidade nas ilustrações, o que vai de encontro às orientações de Alberti.

Talvez a escolha dessa técnica por Palladio, ao representar com essa técnica os edifícios visitados, alguns dos quais já eram conhecidos por seus contemporâneos contemporâneos e arquitetos - fosse uma tentativa de estabelecer uma distinção gráfica bastante clara entre aquilo que era por ele projetado e os edifícios pré-existentes. Distinção entre ideia - um novo edifício - e sua compilação de antiguidades, de que ele faz o levantamento exato, mas depois reelabora, de forma a colocar também as ruínas segundo os seus princípios construtivos: 

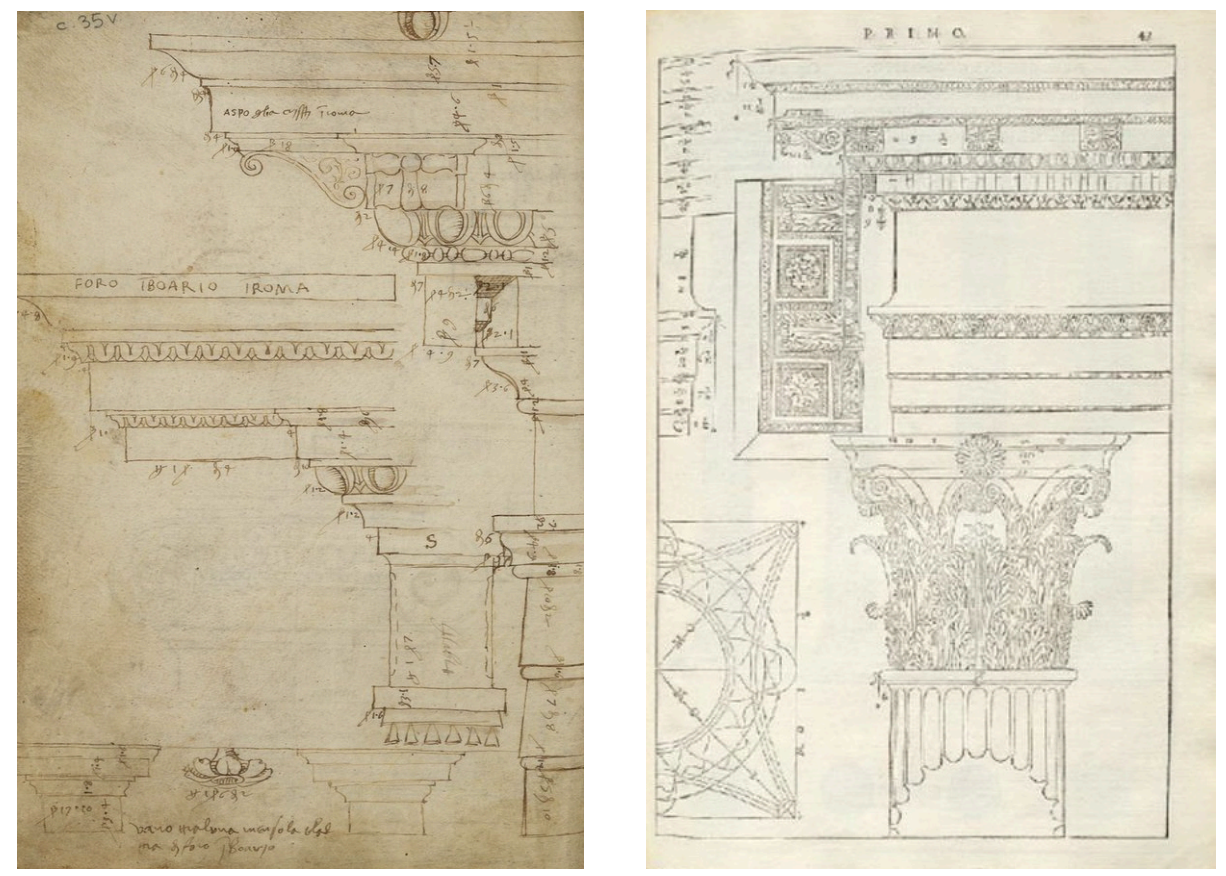

Figura 14 - (esq.) Página 35v do Taccuino Senese, de Giuliano da Sangallo. Fonte: Biblioteca Digital Mundial, disponível em: <http//: http://www.wdl.org/pt/item/10597/view/1/72/>. Figura 15 - (dir.) Página do Livro IV de Palladio. Fonte: Palladio (1570, p.106). 

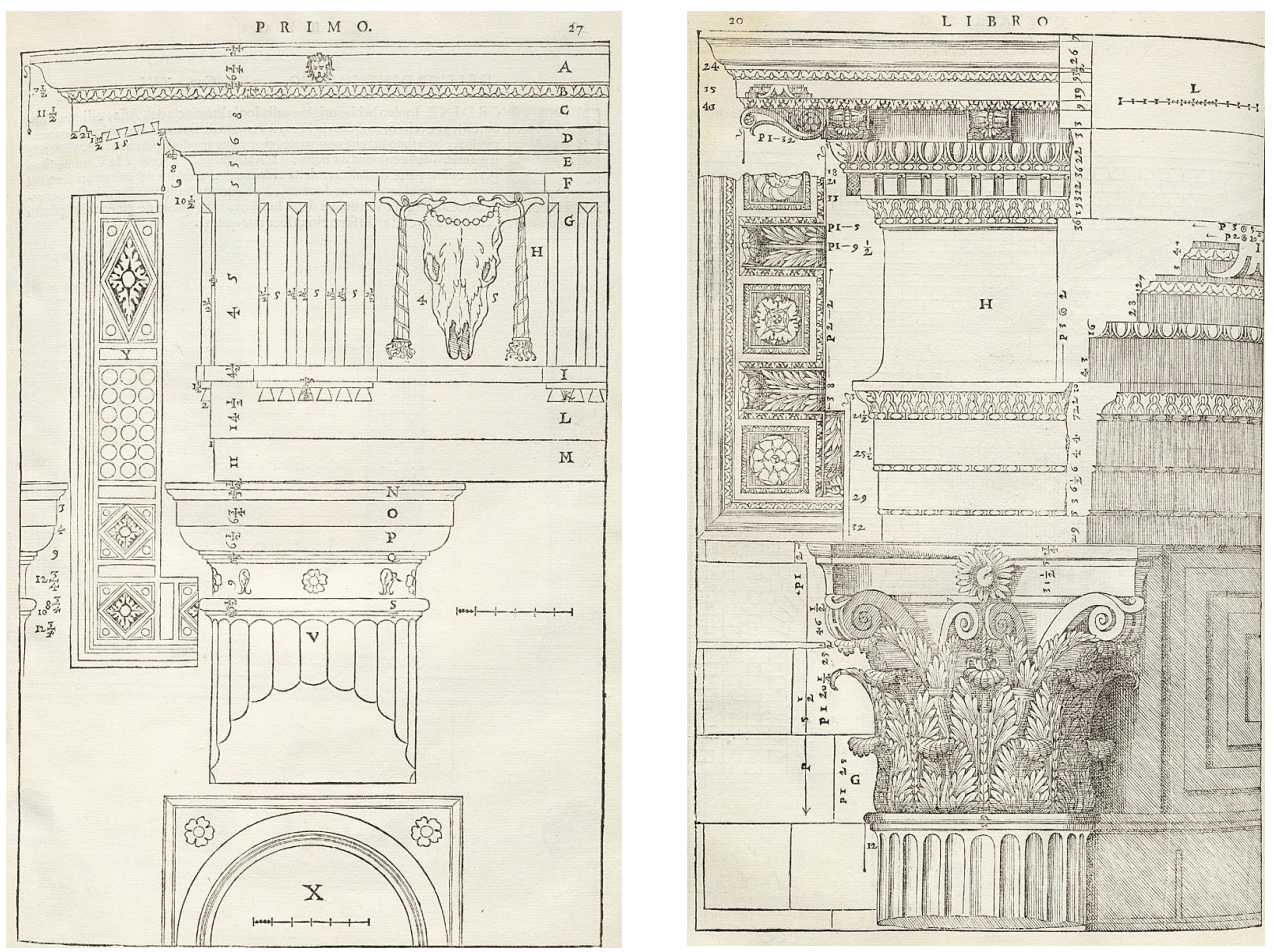

Figura 16 - Detalhe das orientações para o projeto segundo a Ordem Dórica, contendo capitel e entablamento. Fonte: Palladio, Livro I, Cap. XV (1570, p.25). Figura 17 - Detalhe do capitel e entablamento de Ordem Coríntia encontrados no Tempio de Marte Vendicatore. Fonte: Palladio: Livro IV, Cap. XVII. (1570, p.20). 


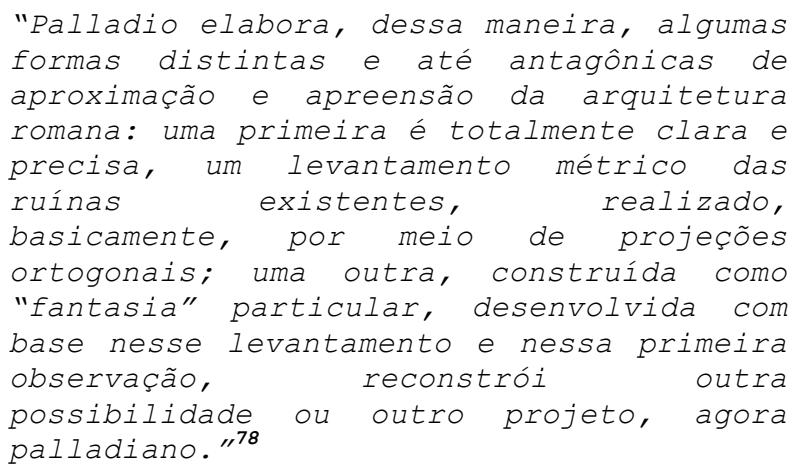

Ao apresentar seus edifícios e suas próprias diretrizes construtivas por meio das projeções ortogonais, ele parece estar justamente lançando mão das orientações albertianas para assegurar que eles fossem bem compreendidos.

\section{Hierarquia social - Adequação das vilas aos proprietários}

No Livro IV, dedicado às obras públicas, Alberti aborda - papel representativo da arquitetura na constituição da cidade, atribuindo a existência de diferentes tipos de edifícios à diversidade do ser humano. Inicialmente ele faz um apanhado de referências antigas, como Plutarco, Aristóteles e Platão, que endossam essa busca por uma classificação dos homens, depois começa a apresentar os princípios que permitiriam diferenciar os homens do seu tempo: a razão e o conhecimento das artes liberais e, possivelmente, a prosperidade de sua boa sorte ${ }^{79}$. E segue com essa classificação para apontar que em seu topo se encontram os administradores e governantes do Estado:

\footnotetext{
"Entre os homens são poucos aqueles que se evidenciam e salientam em todos estes dons simultaneamente. Deste critério surge a primeira divisão, que consiste em seleccionarmos de entre a multidão uns poucos, dos quais uns se elevem por serem notáveis em sabedoria, conselho e inteligência, outros experimentados na vivência e na prática das coisas, outros famosos pela abundância de bens e opulência das suas fortunas. Quem se oporá a que as principais funções do estado Ihes sejam confiadas?" ${ }^{80}$.
}

${ }^{78}$ Cf. Lancha (2005, p.78).

Cf. Alberti, Livro IV, Cap. I (2011a, p.282).

${ }^{80}$ Cf. Alberti, Livro IV, Cap. I (2011a, p.282). 
A responsabilidade de expressar a hierarquia social também se estende à arquitetura residencial, e, para isso, Alberti estabelece o que De Fusco vê como uma autêntica antecipação da distinção social liberal e burguesa ${ }^{81}$. Para cada tipo de homem é atribuído um tipo diferente de edifício, de acordo com sua posição nessa hierarquia: primeiramente os poucos indivíduos dotados de sabedoria, engenho, equilíbrio, experiência prática e fortuna - onde estão enquadrados os governantes; depois os homens que atuam com as armas, as indústrias e as riquezas segundo os direcionamentos apontados pelo primeiro grupo; por fim, todos os demais, que deveriam se sujeitar às duas classes superiores.

Nessa concepção, as exigências dos mais modestos e dos mais opulentos são diferentes, mas ambas devem se sujeitar à moderação "os mais modestos medem pela necessidade o estilo do seu habitar; os mais faustosos apenas na necessidade estabelecem limites ao seu prazer. Quanto a nós, referiremos aquilo que, em cada caso, é aprovado pela moderação de uma pessoa circunspecta." ${ }^{82}$.

Começando pelas residências dos chefes de Estado, Alberti defende que a moradia desses governantes seja variável, como também o sejam as configurações gerais da cidade, dependendo das características do governo. Tanto os edifícios quanto à própria cidade estão sujeitos ao tipo de governo e não devem ser os mesmos para os tiranos e para os que "detêm o poder e o exercem como uma magistratura que Ihes foi concedida." ${ }^{83}$.

Independentemente das formas propostas para cada um deles, "a novidade do método é constituída do fato que o autor elabora o projeto de construção de toda uma cidade, na qual cada particular seja subordinado ao conceito predominante da cidade entendida como um todo orgânico" ${ }^{84}$. Ao contrário do que ocorria no período medieval, onde a preocupação com os vizinhos era apenas com o intuito de copiá-los ou superá-los, "Alberti prefigura a ideia de um

\footnotetext{
${ }^{81}$ Cf. De Fusco (2003, p.136).

82 Cf. Alberti, Livro V, Cap. XV (2011a, p.353).

83 Cf. Alberti, Livro V, Cap. I (2011a, p. 318).

84 Cf. Blunt, A. Le teorie artistiche in Italia dal Rinascimento al Manierismo. Torino: Einaudi, 1966, p.22, apud De Fusco (2003, p.145), tradução nossa, do italiano: "La novità del metodo è costituita dal fatto che l'autore elabora il progetto di costruzione di un'intera città, di cui ogni particolare è subordinato al concetto predominante della città intesa come un tutto organico."
} 
organismo urbano totalmente novo e distinto de que não é fácil formar uma imagem, mas que de qualquer modo reflete uma sólida estrutura conceitual" ${ }^{85}$.

Quando Alberti, em seu discurso, coloca o arquiteto a serviço da expressão e da legitimação do poder, independentemente de sua origem, ele também o coloca no papel de aliado desse governante. Até mesmo quando não se expressam de forma servil, como é o caso de Alberti, os homens de cultura, sobretudo arquitetos, são extremamente fiéis a essa aliança ${ }^{86}$, cuidando constantemente para que, sob todos os aspectos, suas teorias estejam de acordo com o sistema sóciopolítico, e, portanto, urbanístico, vigente.

"Se no sistema brunelleschiano ainda
estavam expressas as aspirações da
primeira sociedade burguesa florentina,
voltada a uma racionalidade universal que
englobava momentos técnicos e econômicos,
Alberti, ao contrário, faz um uso
puramente decorativo das ordens, como
embelezamento de uma arquitetura a
serviço do Príncipe." ${ }^{77}$

Palladio também propõe uma hierarquia para seus edifícios com base nas classes de seus proprietários no início do Livro II de seu tratado, mas não menciona Alberti optando por fazer referência à hierarquia vitruviana no início de sua explicação e continua apresentando sua classificação, dividindo os homens em quatro grupos e estabelecendo as diretrizes específicas para o projeto de residência para cada um deles:

"Portanto deverá o Arquiteto sobretudo
observar que (como diz Vitruvio no
primeiro e no sexto livro) aos gentis-
homens grandes e especialmente de
República serão requisitadas casas com
loggie e salas espaçosas e ornamentadas:
de modo que em tais lugares possa ficar
com prazer quem estiver esperando o

\footnotetext{
85 De Fusco (2003, p.145). Tradução da autora, do italiano: "Alberti prefigura l'idea d'un organismo urbano affatto nuovo e distinto di cui non è agevole formarsi un'immagine, ma che rispecchia comunque una salda struttura concettuale.

${ }^{86}$ Cf. De Fusco (2003, p.150).

87 Cf. Thoenes (1998, p.70), tradução da autora, do italiano: "Se nel sistema brunelleschiano trovavano ancora in certo modo espressione le aspirazioni della prima società borghese fiorentina improntate a una razionalità universale che inglobava momenti tecnici ed economici, con Alberti, invece, fa la sua comparsa un uso puramente decorativo dell'ordine, come abellimento di un'architettura a servizio del Principe."
} 
patrão para cumprimentá-lo ou para pedirIhe alguma ajuda e favor. $E$ aos gentishomens menores hão de convir também construções menores, de menos despesa e sem adornos. Aos Solicitadores e Advogados se deverá construir da mesma maneira, para que nas suas casas haja belos lugares de passeio e adornos, a fim de que os clientes aí permaneçam sem tédio deles. As casas dos mercadores terão os lugares onde se põem as mercadorias voltados para o Norte, e dispostas de maneira tal que os patrões não venham a temer ladrões." 88

A referência que faz Palladio está no Livro VI do tratado de Vitruvio, onde podemos verificar - destacados em negrito - os quatro grupos de homens identificados pelo autor e as consequentes orientações que ele fornece para o projeto de suas residências:

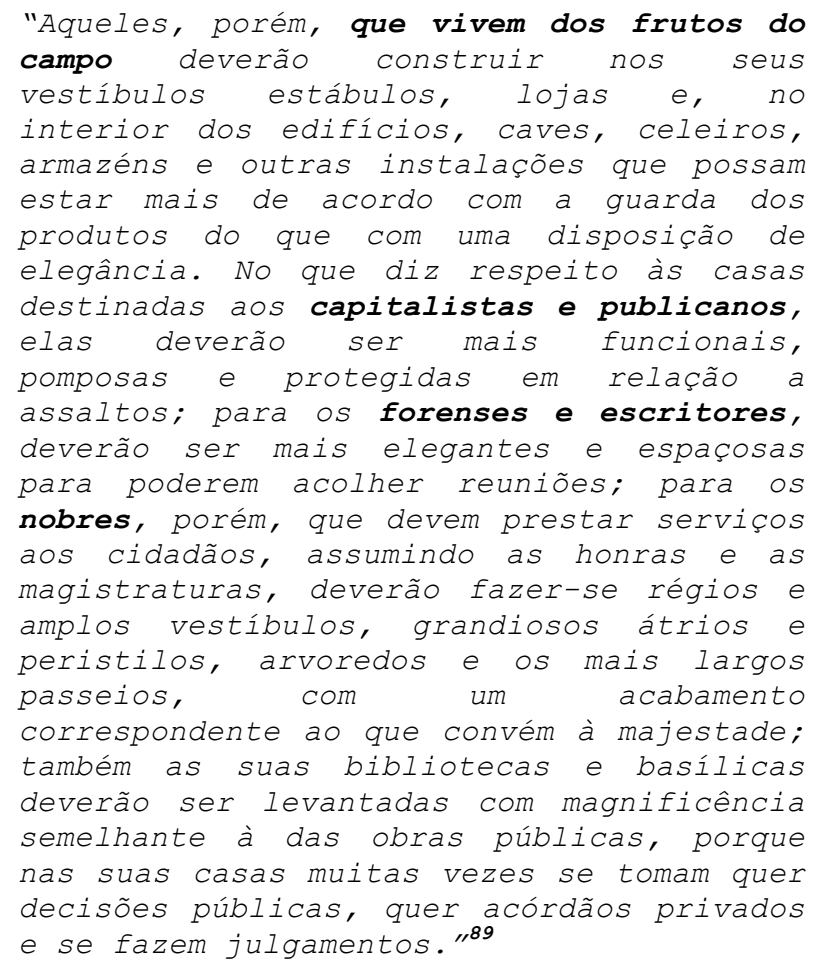

A coincidência entre as recomendações feitas pelos dois autores é grande, ainda que os grupos de homens não sejam exatamente os mesmos: para os nobres/gentis-homens grandes -

88 Palladio, Livro II, Cap. I (2009, p.71).

89 Vitruvio, Livro VI, Cap.5 (2007, p.311-312). Grifo nosso. 
espaços amplos e ricamente ornamentados; para os forenses e escritores/solicitadores e advogados - espaços amplos e elegantes; para os capitalistas e publicanos/mercadores funcionais e seguras; para aqueles que vivem dos frutos do campo/gentis-homens menores - menores, sem ornamentação, voltadas para a utilidade.

Apesar de fazer essa opção pelo texto vitruviano, sem mencionar as proposições de Alberti, pode-se perceber, pela síntese apresentada na Tabela 5, que as três classificações são muito semelhantes entre si e que o que aproxima Palladio mais de Vitruvio do que de Alberti é a subdivisão no grupo intermediário, que este não faz:

\begin{tabular}{|c|c|c|}
\hline Vitruvio & Palladio & Alberti \\
\hline Nobres & Gentis-homens grandes & $\begin{array}{c}\text { Nobres e } \\
\text { Governantes }\end{array}$ \\
\hline Forenses/escritores & Solicitadores/advogados & \multirow{2}{*}{$\begin{array}{c}\text { Atuam com armas, } \\
\text { indústrias e } \\
\text { riquezas }\end{array}$} \\
\hline Capitalistas/publicanos & Mercadores & \\
\hline Camponeses & Gentis-homens menores & Todos os demais \\
\hline
\end{tabular}

Tabela 5 - Síntese da classificação hierárquica dos homens para Vitruvio, Alberti e Palladio.

Alberti, entretanto, ao fazer suas orientações práticas para o projeto residencial, ignora essa primeira hierarquia que havia proposto e estabelece outra também com três grupos, onde a principal mudança é a diminuição dos integrantes desse grupo principal: primeiro os mais altos dignitários ${ }^{91}$, que são aqueles a quem é confiada a autoridade suprema e a direção do Estado (o rei e o tirano); depois todos os homens livres; por fim, os servos da gleba.

90 Ao descrever os poucos indivíduos que se enquadram nessa categoria, Alberti lista características que eram valorizadas e atribuídas aos grandes Humanistas de seu tempo, como Lorenzo Médici: dotado de sabedoria, engenho, equilíbrio, experiência prática e fortuna.

91 Sobre isso, Krüger (2011, p.317, nota $\left.{ }^{\circ} 819\right)$ alerta para o conjunto da obra albertiana: "A formação de uma classe dirigente, cujas aspirações se revêem em interesses colectivos e não individuais, à semelhança do que sucedia na República Romana, é recorrente na obra literária de Alberti, como sucede nas Intercenales e no Momus, ao contrário do que expõe no tratado, onde se limita a descrever os meios para satisfazer as necessidades defensivas da cidade governada por reis, como regida por tiranos." 
Os comitentes de Palladio formavam um grupo relativamente homogêneo de aristocratas venezianos e da terra firme, que investiram seu capital na terra e que dela tiravam os rendimentos nos quais se baseava seu bem-estar econômico e sua posição social ${ }^{92}$.

Se optasse pela hierarquia albertiana, ele iria automaticamente tirar seus comitentes do nível mais alto da hierarquia, o que pode justificar sua preferência por Vitruvio. Além disso, as diretrizes apresentadas por Alberti são menos lineares e a subdivisão entre elas é ainda menos nítida nas recomendações de projeto, como pode ser percebido no trecho a seguir:

"os edifícios habitados pelos reis e
pelos tiranos têm muitos aspectos em
comum entre si e também com os edificios
plebeus de proprietários particulares,
mas em outros aspectos apresentam
diferenças relativamente a estes e em
relaça uns aos outros. Falaremos em
primeiro lugar daquilo que lhes é comum
e, a seguir, daquilo que é peculiar de
cada um." 93

Independentemente dos motivos, é somente na teoria que Palladio opta por estabelecer relações com o texto de Vitruvio, já que na prática seus projetos de vila apresentam inúmeras semelhanças com as vilas que Alberti descreve para os homens-livres e também com aquelas destinadas aos príncipes. Como já foi mencionado anteriormente, o texto de Vitruvio pouco pôde contribuir para o projeto de vilas, enquanto aquele de Alberti estabeleceu as bases para a produção renascentista de vilas e casas de vila e era, portanto, natural que as vilas de Palladio também o tivesse tomado como interlocutor.

Conforme foi descrito no início desse capítulo, quando organiza seus projetos de vilas no tratado, Palladio faz duas separações, uma que aparta a Villa Capra das demais e a inclui entre as residências projetadas para a cidade ${ }^{94}$, e outra em que divide todas as demais em dois grupos, segundo a origem de seus proprietários: nobres venezianos e gentishomens de terra firme.

\footnotetext{
92 Cf. Visentini (1995, p.251).

93 Alberti, Livro V, Cap. I (2011a, p.320).

94 Segundo o próprio autor essa escolha se deve à localização da vila ser muito próxima de Vicenza.
} 
Ainda que faça questão de afirmar que a sequência em que as vilas são apresentadas não segue qualquer tipo de hierarquia, no primeiro capítulo do Livro II Palladio escreve sobre o Decoro, ou Conveniência, que se deve observar nas construções particulares. Logo no início desse texto ele atribui a comodidade da residência a dois fatores: sua conveniência à qualidade de quem irá habitá-la; e a correspondência de suas partes com o todo e entre si mesmas. No final desse capítulo ele volta ao tema, enfatizando a prioridade que deve ser dada à, assim definida, comodidade:

\begin{abstract}
"Se deverá portanto (como disse), o quanto se possa, observar os que querem construir e não tanto $\circ$ que eles podem, mas sim qualidade de construção que lhes vá bem; e depois que se tiver escolhido, se disporão em modo as partes que convenham ao todo e entre si mesmas" ${ }^{95}$.
\end{abstract}

A partir do estudo dos projetos é possível identificar algumas semelhanças que permitem organizar as vilas em grupos, de acordo com características em comum.

Tendo em vista que nas páginas do tratado, as vilas foram colocadas em escalas diferentes para se ajustarem à diagramação, elas foram redesenhadas para desenvolvimento desse estudo, com base nas medidas indicadas nos desenhos. Quando as medidas eram insuficientes, foram tomadas como referência as orientações escritas por Palladio para o projeto de cada parte do edifício.

Primeiramente, como pode ser visto nas elevações esquemáticas reunidas na Figura 18, as vilas destinadas aos proprietários venezianos (em preto) são menores do que as dos gentis-homens de terra firme (em vermelho), comparação feita entre vilas de tipologias semelhantes.

Por outro lado, as residências dos venezianos apresentam maior riqueza de ornamentos tanto externa quanto internamente. Essa característica pode estar relacionada à função da vila mais que à origem de seus proprietários, já que a grande parte dos comitentes venezianos tinha sua residência principal na cidade e utilizava a vila como local de repouso e realização de festas e recepções, possibilidade que ganha força observando-se as residências patronais dessas vilas.

95 Palladio, Livro II, Cap. I (2009, p.71). 

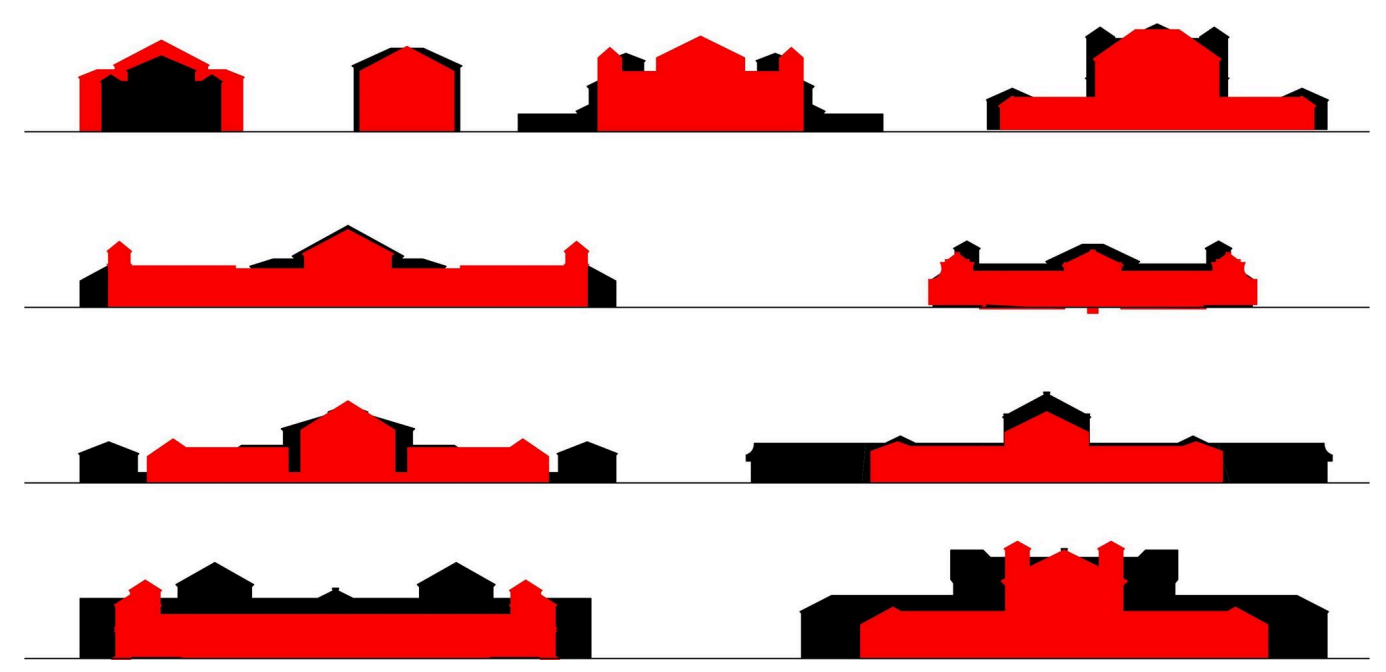

Figura 18 - Representação esquemática das fachadas das vilas apresentadas no tratado. Em preto, as vilas dos proprietários de terra firme e em vermelho as vilas dos proprietários venezianos. 
Outra possibilidade, quanto à variação na ornamentação, pode estar relacionada com a época em que as vilas foram projetadas. As primeiras vilas de Palladio são aquelas com menos referências às ordens clássicas, o que não acontece nos seus primeiros palácios. Essa dualidade permaneceu ao longo do tempo em seus projetos e Palladio parecia perseguir um equilíbrio entre os dois estilos antitéticos ${ }^{96}$.

As primeiras vilas de Palladio ainda apresentavam formas menos trabalhadas, como pode ser visto no projeto da Villa Godi, um edifício maciço e severo que, alinhado à tradição local, desenvolve em dois pavimentos uma planta com dois rígidos blocos laterais, provavelmente condicionados por preexistências. Ao centro esses blocos são unidos por uma loggia central recuada, precedida por uma escadaria, onde se vê a concisão de detalhes decorativos (Figuras 19 e 20). Battilotti ${ }^{97}$ afirma ser esse um bom exemplo dos projetos que Palladio refaz, já com alguma maturidade e lucidez, para inserir no tratado "o projeto 'correto' contraindo os corpos laterais, rebaixando o pavimento térreo e elevando o núcleo central".

A implantação dessa vila no topo de uma colina repete uma solução bastante conhecida e frequentemente adotada nos projetos de castelos que predominavam nos campos. Além disso, toda a propriedade é circundada por muros que não eram altos - bastante para proporcionar sua defesa, mas que funcionavam como uma delimitação simbólica do território sem, contudo, obstruir a vista da paisagem. "O complexo cercado por muros retoma uma disposição suburbana difusa no século precedente na Itália central e recorda a vila ideal descrita por Alberti, fundada sobre uma síntese de exemplos clássicos e prática medieval"98

A Villa Pisani, em Bagnolo, que data de 1542, ainda que tenha sido realizada para um comitente veneziano, ao contrário da Villa Godi, apresenta semelhante concisão nos detalhes. Além disso, nesse projeto a vila possui uma

\footnotetext{
${ }_{96}$ Cf. Ackerman (1996, p.20).

97 Battilotti (2011, 12). Tradução da autora, do italiano: "il progetto 'corretto' contraendo gli avancorpi laterali, ribassando il pianterreno e rialzando il nucleo centrale."

98 Ackerman (1996, p.23). Tradução da autora, do italiano: "Il complesso racchiuso da mura riprende una disposizione suburbana diffusa nel secolo precedente nell'Italia centrale e richiama la villa ideale descritta dall'Alberti, fondata su una sintesi di esempi classici e di pratica medievale."
} 
barquessa de grandes dimensões, que indica a produção agrícola como função primordial nessa vila.

A proposta de uma arquitetura residencial menos opulenta e com menos ornamentação, apesar de divergir da tradição humanística de influência vitruviana, também era inspirada na Roma Antiga, mas naquela dos edifícios como o Pantheon e as termas ${ }^{99}$.

$$
\begin{aligned}
& \text { "A incerta datação das primeiras obras e } \\
& \text { de diversas experimentaçoes gráficas } \\
& \text { juvenis não permite apurar se as } \\
& \text { caracteristicas arqueologizantes e os } \\
& \text { elementos derivados das experiências dos } \\
& \text { mestres contemporâneos nele verificados } \\
& \text { são citaçes extraídas de desenhos } \\
& \text { alheios, em particular de serlio, ou são } \\
& \text { ao contrário produto de um conhecimento } \\
& \text { direto das arquiteturas antigas e } \\
& \text { modernas de Roma."100 }
\end{aligned}
$$

Conforme referido no capítulo anterior, a formação de Palladio ocorreu através do estudo de textos e disciplinas relacionadas à arquitetura e também com a realização de viagens de estudo. No Proêmio do tratado, Palladio cita essas duas etapas, fazendo referência ao texto de Vitruvio, "o qual é o único escritor antigo desta arte"101, e o de Alberti, além de mencionar também o estudo das ruínas:

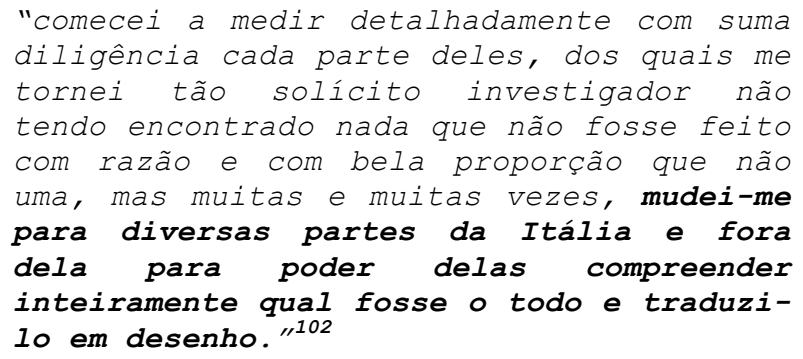

\footnotetext{
99 Ackerman (1996, p.20).

100 Battilotti (2011, p.12). Tradução da autora, do italiano: "L'incerta datazione delle prime opere e di diverse prove grafiche giovanili non consente di appurare se $i$ caratteri archeologizzanti e gli elementi derivati dalle esperienze dei maestri contemporanei in esse riscontrabili siano citazioni estratte da disegni altrui, i particolare di serlio, o siano invece prodotto di una conoscenza diretta delle architetture antiche e moderne di Roma."

101 Palladio, Livro I, Proêmio (2009, p.5).

102 Palladio, Livro I, Proêmio (2009, p.5).
} 

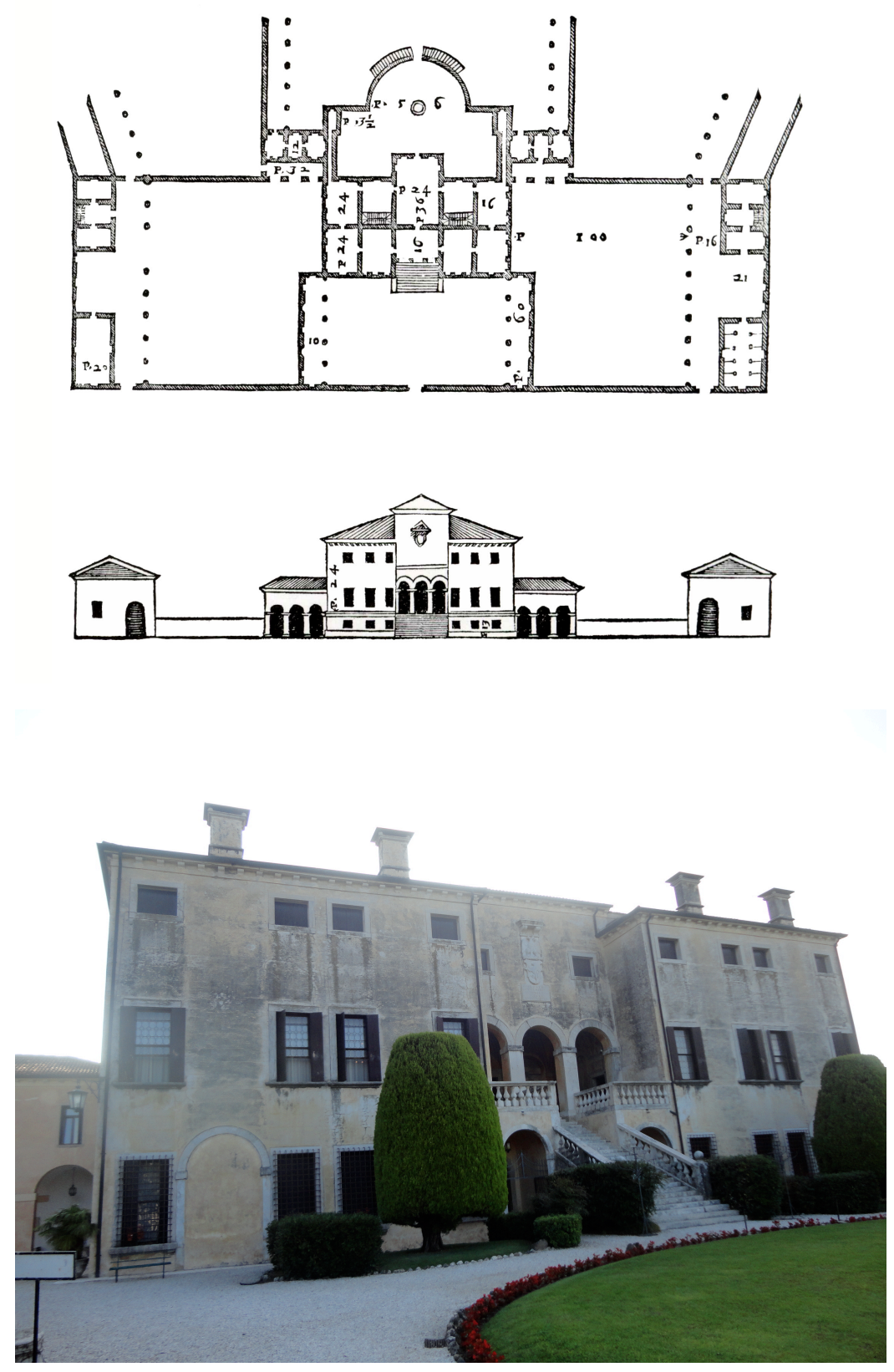

Figura 19 - Villa Godi, projeto apresentado no tratado (sup). Figura 20 - vista da fachada atual (inf). 
De fato, nessas viagens Palladio se revela um "viajante incansável e estudioso verdadeiramente excepcional para seus tempos, revelando uma curiosidade apaixonada e quase romântica pela antiguidade, tipicamente veneta, que o aparenta não apenas ao predecessor Falconetto, mas também a Fra Giocondo e a Mantegna."103

Magagnato ainda acrescenta a leitura de história antiga e topografia romana, assim como a realização de cópias de cadernos de desenho de outros arquitetos. Nesse processo de estudos, "Os desenhos criados dos edifícios da Antiguidade são tão importantes quanto seus próprios projetos, uma vez que passam a ser o testemunho de suas opcões, de suas escolhas diante da obra de arquitetura"104

Ao contrário das duas descritas anteriormente, Villa Barbaro, em Maser, (projetada por volta de 1554), é um exemplo de vila que "como a maior parte das vilas paladianas, exprimia o melhor dos dois mundos, o aristocrático e o rural." ${ }^{105}$. Concebida para os irmãos Daniele e Marcantonio Barbaro, nascidos em uma nobre família veneziana, a vila estava situada a uma grande distância da sociedade citadina e não era apenas uma vila de recreio para seus proprietários, mas sua residência principal, destinada ao controle das terras e da produção, já que dela vinham os lucros que asseguravam $\circ$ luxo em que viviam ${ }^{106}$.

Os dois irmãos receberam educação humanista e frequentaram a Universidade de Pádua e eram os homens mais universais entre todos nobres dos campos vênetos. Foi Daniele quem organizou e publicou a edição do tratado de Vitruvio ilustrada por Palladio. Ele também era conhecedor da filosofia aristotélica, estudioso de perspectiva, matemático e embaixador, eleito pela República como patriarca de Aquilea.

A vila está inserida aos pés de uma colina, em um ponto do terreno elevado o suficiente para se ter uma visão satisfatória da paisagem dos campos e pomares ou para deles ser vista ${ }^{107}$.

\footnotetext{
103 Cf. Zorzi, (1969, p. 24).

104 Cf. Lancha (2005, p.77).

105 Ackerman (1996, p.19). Tradução da autora, do italiano: "In poche parole Maser, come la maggior parte delle ville palladiane, esprimeva il meglio dei due mondi, quello aristocratico e quello rurale."

106 Cf. Ackerman (1996, p.18).

107 Cf. Ackerman (1996, p.18).
} 
A casa se abre para o ambiente externo, demonstrando que a preocupação com a segurança nos campos já não era mais um limitador do projeto, como acontecia até o final do século XV. Uma parte do corpo principal se estende à frente do volume, o que permitia dotar três de seus lados de aberturas. De cada lado da residência se estendem barquessas e arcadas que permitem ao proprietário percorrer rapidamente, e protegido das intempéries, toda essa zona destinada à produção.

Quanto à ornamentação, essa vila se destaca não somente entre as outras vilas paladianas, como também entre suas contemporâneas do norte da Itália, sendo, para Ackerman ${ }^{108}$, aquela de maior riqueza e beleza em sua decoração.

Por esses três exemplos é possível perceber-se que, ainda que existam algumas afinidades entre a maior parte das vilas colocadas em cada um dos dois grupos, não é possível estabelecer uma hierarquia que se aplique a todas elas. De fato, como Palladio escreve no tratado, deve-se observar cada comitente e cada projeto individualmente:

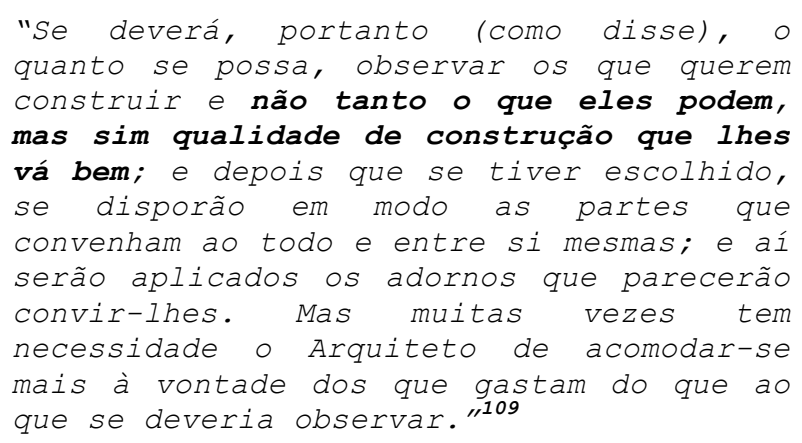

No texto reproduzido acima, pode-se ver - em negrito demonstração significativa da importância de se observar a conveniência da construção em relação ao tipo de comitente. Para se ter compreensão da importância dessa afirmação é necessário falar de outro ponto muito importante para Palladio - a economia.

108 Cf. Ackerman (1996, p.18).

109 Palladio, Livro II, Cap. I (2009, p.71). 

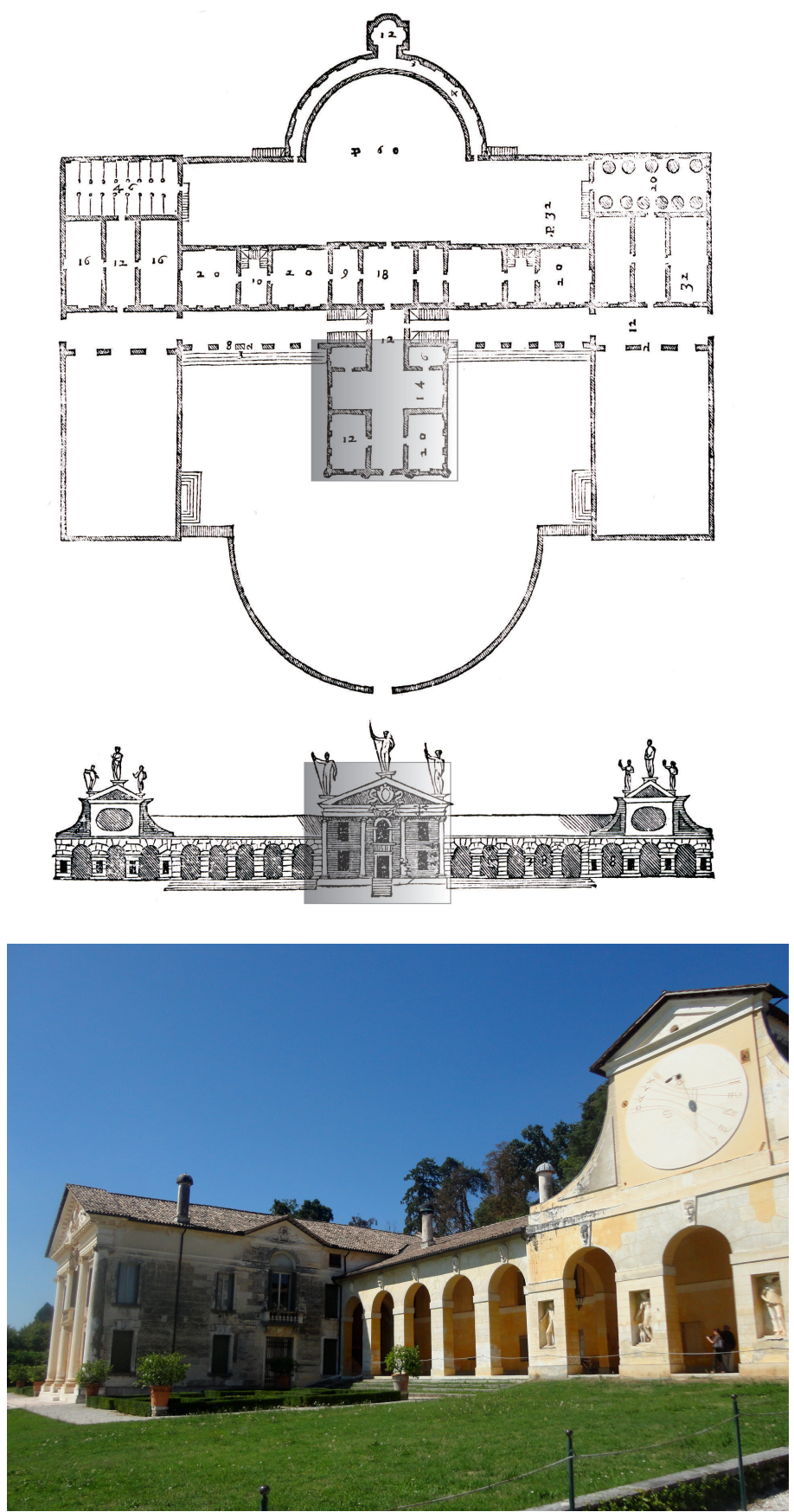

Figura 21 - Página do tratado em que é apresentado o projeto da Villa Barbaro, com destaque para o volume que se estende à frente do corpo principal. Figura 22 - Vista lateral da vila mostrando o avanço do corpo central em relação à loggia lateral. 
Anteriormente, Alberti já manifestava preocupação com a previsão dos custos e materiais envolvidos na obra. No segundo livro do tratado, ao tratar dos materiais de construção, ele faz uma série de recomendações quanto ao planejamento da obra a fim de aproveitar bem os recursos e ter as condições necessárias para terminá-la. A preocupação albertiana, entretanto, era mais voltada ao planejamento do que à economia, o que fica evidente quando ele afirma que a maior parte das encomendas de projetos de vilas vinha dos proprietários ricos e esse era um dos motivos que tornava esse tipo de projeto mais livre de obstáculos do que das residências citadinas ${ }^{110}$.

Palladio, por sua vez, tinha grande preocupação com a economia em seus projetos, o que se manifestava na escolha de materiais para execução da obra e também acabava se refletindo na ornamentação dos edifícios. Em grande parte de seus projetos de vilas a ornamentação clássica era bastante reduzida, muitas vezes restringindo-se ao pórtico na fachada principal, enquanto o restante do edifício apresentava ornamentação bastante simples e geométrica ${ }^{111}$.

As colunas eram quase sempre feitas em alvenaria de tijolos (Fig. 23) deixando a pedra somente para os elementos mais detalhados - tais como bases, capitéis e cornijas exceto em casos específicos onde fosse necessário seu emprego, como na Villa Sarego, em Santa Sofia. Da mesma forma, as arquitraves que não desempenhavam função estrutural eram feitas em madeira e revestidas com estuque (Figura 24).

Embora no tratado Palladio não mencione o período em que atuou como tagliapietre, essa prática provavelmente deu a ele maior compreensão dos sistemas estruturais tornando-o hábil em obter formas clássicas mesmo empregando materiais considerados menos nobres. Da mesma forma, essa capacidade de reduzir custos, ao minimizar a utilização de materiais caros como mármores e pedras, provavelmente possibilitava a ele afirmar que, em um primeiro momento, a adequação do edifício ao comitente é mais importante que os recursos financeiros disponíveis. Ainda que os recursos fossem limitados, a conveniência das formas poderia ser assegurada por meio da economia.

110 Cf. Alberti, Livro V, Cap. XIV (2011a., p.353).

111 Ackerman (1996, p.32). 

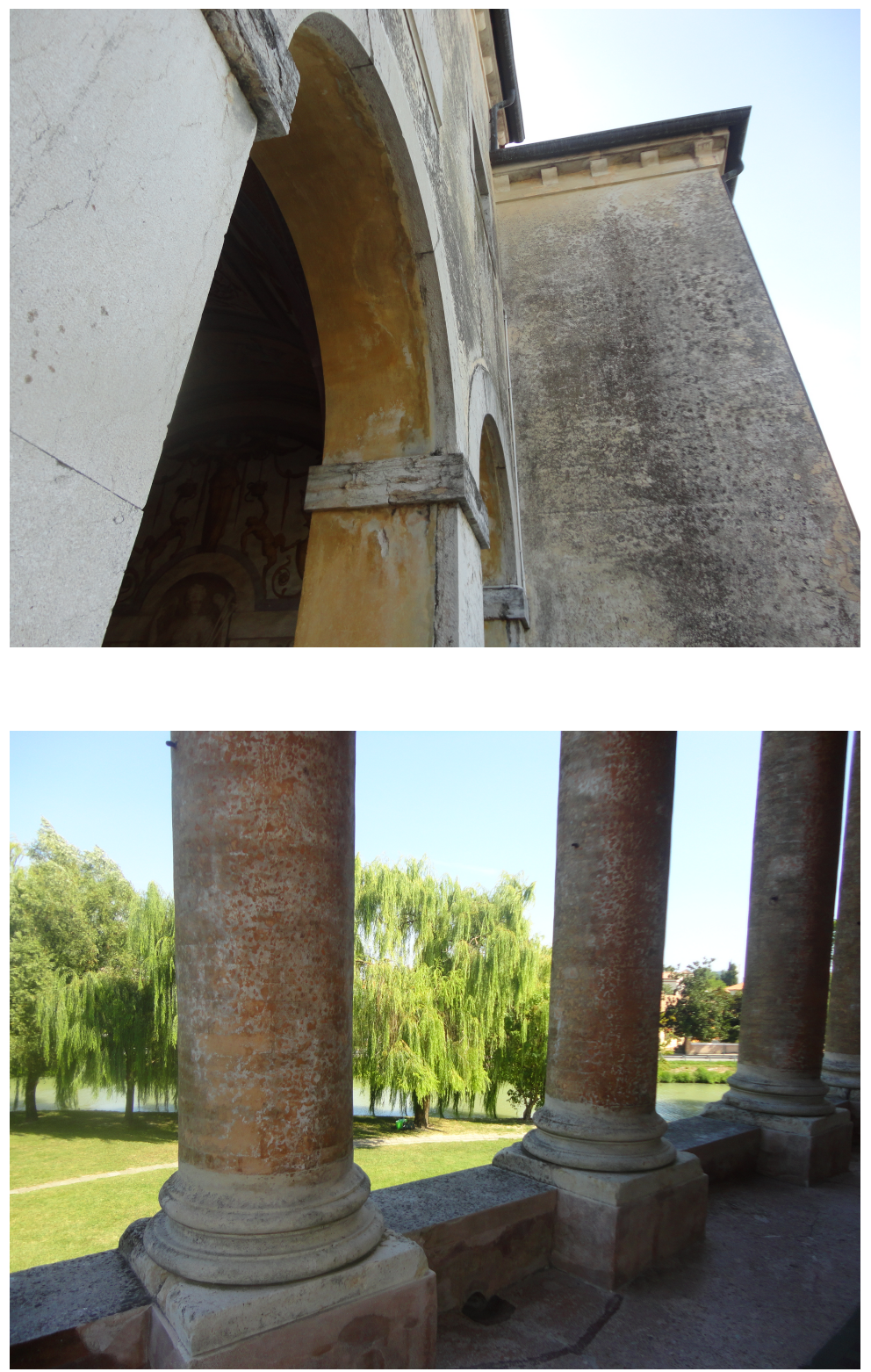

Figura 23: Detalhe da arquitrave da Vila Godi, onde se percebe a utilização de madeira revestida com estuque. Figura 24: Colunas de tijolos na loggia da Villa Foscari. 
No capítulo em que trata Dos Abusos, Palladio faz diversas orientações sobre onde deve ser empregada a pedra, bem como orienta acerca dos ornamentos que devem ser evitados, por serem desnecessários e "nem outro efeito produzem senão o que aumenta a despesa dos edificadores." $" 112$.

O aumento da preocupação com a economia, de Alberti para Palladio, provavelmente está relacionado com a mudança no perfil dos comitentes. Por volta de 1450 a burguesia começava a ganhar espaço, mas o consumo de arquitetura ainda estava muito restrito à nobreza, aos governantes - figuras como Cosimo e Lorenzo Médici - e talvez por isso esses fossem os personagens mais importantes da hierarquia albertiana.

Cem anos depois, entretanto, as relações sociais estavam bastante modificadas e a burguesia já estava consolidada, passando a aplicar seus fundos em propriedades agrícolas para diversificar os investimentos. Por outro lado, seus recursos não eram ilimitados e nem mesmo invariáveis, o que exigia maior capacidade de se prever as despesas e, também, a economia.

\section{Compartimentação e setorização}

A organização interna dos edifícios é um argumento importante na obra dos dois autores, que apresentam algumas afinidades significativas. O primeiro ponto de grande importância é a afirmação albertiana de que muitas recomendações feitas para as cidades também devem ser observadas no projeto residencial, fazendo menção aos antigos e recuperando a máxima de Platão: "Ora se a cidade é, na opinião dos filósofos, uma casa em ponto grande e, inversamente, a casa é uma cidade em ponto pequeno, porque não se há-de dizer que as partes mais pequenas das casas são habitações em ponto pequeno? Como, por exemplo, o átrio, o pátio, a sala de jantar, o pórtico, etc." ${ }^{113}$.

Essa relação proposta por Alberti é retomada por Palladio, quando ele fala da escolha do lugar para as vilas: "ao se escolher o lugar para a construção da Villa, todas essas considerações se devem fazer como se faz ao escolher o lugar para as Cidades, de modo que a Cidade não seja senão

Palladio, Livro I, Cap. XX (2009, p.51).

113 Alberti, Livro I, Cap. IX (2011a, p.170). 
uma certa casa grande e, por sua vez, a casa uma cidade pequena"114.

A convergência nesse ponto da argumentação dos dois autores é extremamente importante por discutir a continuidade entre arquitetura e urbanismo e, talvez ainda mais significativa, por extrapolar os limites da própria urbanos ao levá-la para o campo, demonstrando ainda mais uma vez a estreita relação que existia entre a vila e a cidade. De Fusco ${ }^{115}$ afirma ser extremamente significativo o fato de Alberti atribuir aos antigos a origem dessa teoria tão recorrente nas utopias urbanísticas, também sinalizando que nesse discurso ele fez a primeira referência explícita à beleza arquitetônico-urbanística.

Ao falar da organização das casas Alberti reforça essa relação de continuidade entre arquitetura e urbanismo em vários momentos, retomando diretrizes que forneceu para a configuração da cidade e aplicá-las ao edifício. Quando começa a discorrer sobre os edificios particulares, uma de suas primeiras orientações vai nesse sentido: "tal como sucede nas cidades, assim também relativamente às casas, há umas partes que são de todos, outras de uns poucos e outras individuais."116

Alberti começa a fornecer diretrizes para a compartimentação dos edifícios no Livro I, Capítulo VIII, onde destaca a importância da etapa do projeto e retoma o conceito vitruviano de comensurabilidade (symmetria) ${ }^{117,}$ relacionando a determinação das partes com a composição do edifício como um todo:

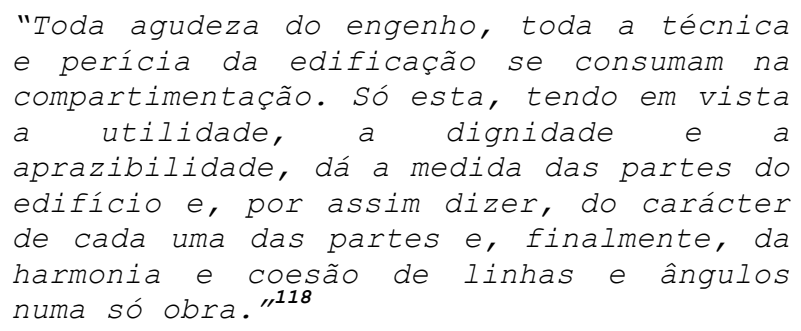

Palladio faz uma afirmação semelhante no início do Livro II, Capítulo I, em que trata do decoro e da

\footnotetext{
114 Palladio, Livro II, Cap. XII (2009, p.114).

115 Cf. De Fusco (2003, p.124-126).

116 Alberti, Livro V, Cap. I (2011a, p.320).

117 Cf. Pollio (2007, p.76): "consiste no conveniente equilíbrio dos membros da própria obra e na correspondência de uma determinada parte".

118 Alberti, Livro I, Cap. IX (2011a, p.170).
} 
conveniência das construções particulares: "Por cômoda se entenderá a casa conveniente à qualidade de quem nela haverá de habitar, e as suas partes corresponderão ao todo e entre si mesmas"119.

$\mathrm{Na}$ busca das justas proporções para a compartimentação dos edifícios, os dois autores lançam mão de comparações do edifício com a natureza e o corpo humano. Escreve Alberti: "e assim como convém que, num ser vivo, haja proporção entre os seus membros, assim também, num edifício, deve suceder o mesmo entre as várias partes. Daí deriva o princípio afirmado por alguns: convém que sejam maiores os membros dos edifícios maiores. "120.

Palladio também escreve sobre a necessidade de se observar o Decoro, na relação entre as partes e o todo, com os cômodos proporcionais ao tamanho do edifício e dispostos de forma que convenham ao todo e entre si mesmos. O teor da recomendação paladiana que trata dessas proporções entre o edifício e suas partes é muito semelhante àquela feita por Alberti:

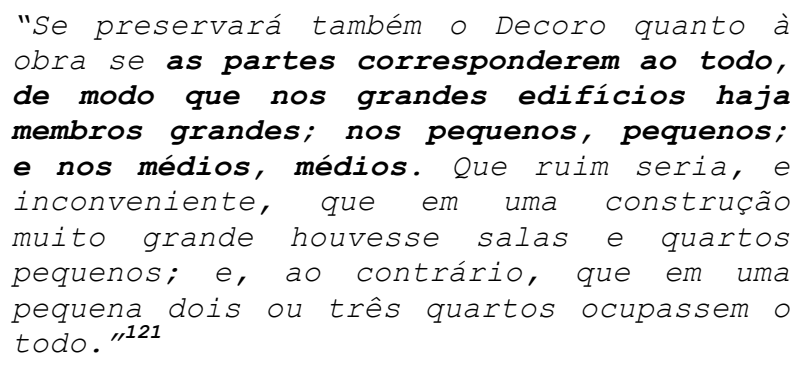

Analisando-se alguns projetos de vilas de Palladio é possível perceber que essa relação é colocada em prática. Duas vilas de tipologia semelhante, onde essa premissa é mais facilmente percebida são a Villa Trissino, em Meledo, e a Villa Capra (Figura 25). As duas vilas possuem loggie com entradas nas quatro fachadas e vestíbulos alongados conduzindo à sala central com planta circular, coberta por uma cúpula. Cada uma delas também possui quatro apartamentos iguais.

Palladio, Livro II, Cap. I (2009, p.71).

120 Alberti, Livro I, Cap. IX (2011a, p.170). Grifo nosso.

121 Palladio, Livro II, Cap. I (2009, p.71). Grifo nosso. 

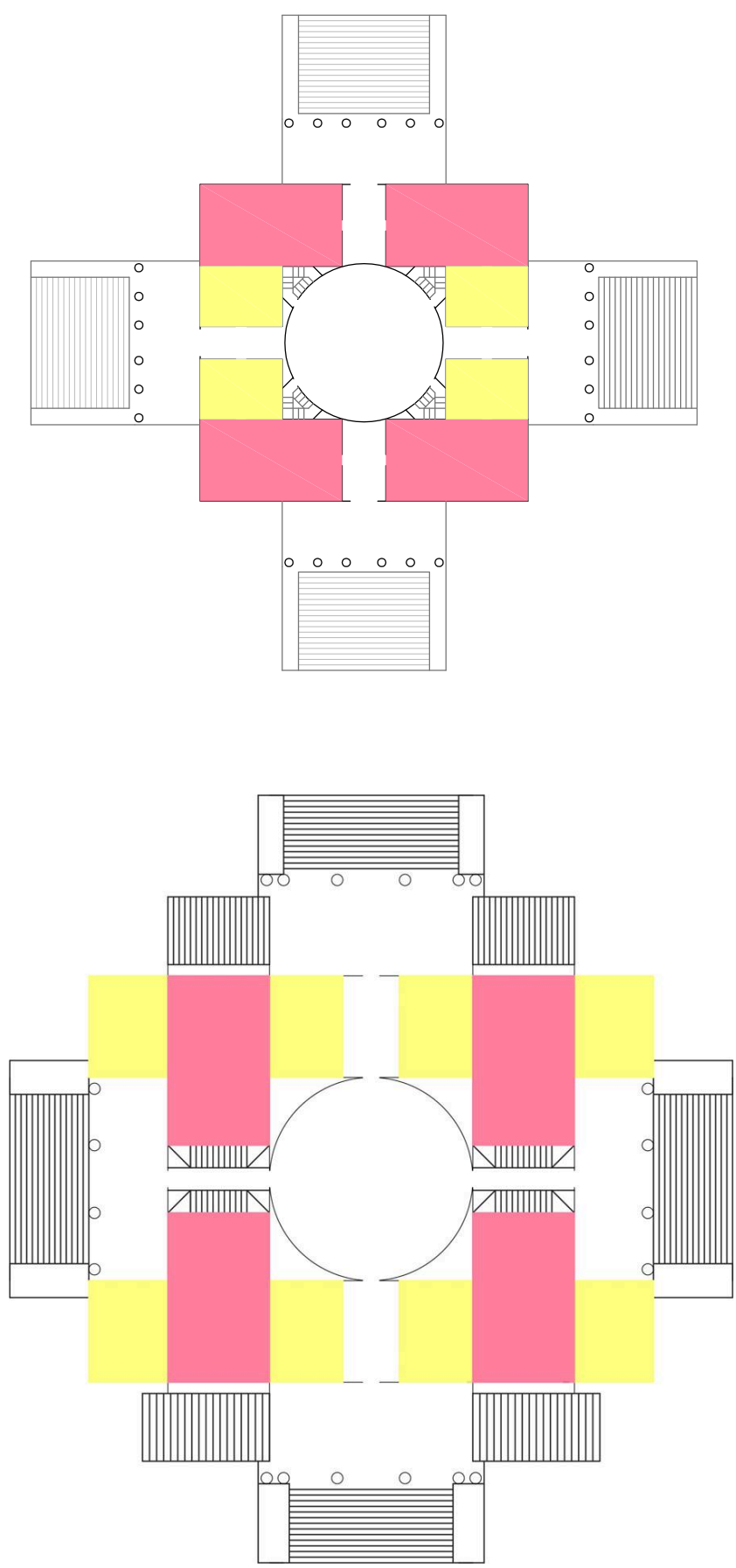

Figura 25 - Plantas esquemáticas da Villa Capra (sup.) e da Villa Trissino, em Meledo (inf.). 
Os desenhos esquemáticos de planta e elevação foram feitos na mesma escala, o que permite comparar as duas vilas e perceber que, não somente os cômodos da Villa Trissino são maiores, mas também cada um dos seus apartamentos possui 3 compartimentos, enquanto na Villa Capra são somente dois.

A ênfase dada à relação entre o todo e as partes e aos problemas de proporcionalidade no tratado de Alberti é, segundo Burns ${ }^{122}$, um dos principais pontos em que se percebe a referência a Vitruvio. Já no tratado de Palladio, isso pode significar tanto uma influência vitruviana quanto, mais provavelmente, uma referência ao próprio Alberti, tendo-se em vista a coincidência de alguns argumentos entre os dois autores que foi apresentada anteriormente.

$\mathrm{Na}$ sequência, novamente lançando mão da analogia entre edifício e corpo, Alberti continua falando sobre a disposição e o dimensionamento dos compartimentos, já esboçando uma setorização dos espaços internos no interior da vila, a partir das funções que eles desempenham:

"a cada membro será atribuída uma zona
apropriada, uma posição adequada, nem
mais ampla do que a sua função exige, nem
mais exígua do que a sua dignidade
postula, nem em lugar impróprio e
inadequado, mas no seu e de tal modo
próprio que noutro lugar, em parte
alguma, possa ser situado de forma mais
conveniente. Assim, a parte do edifício
que virá a ser a mais nobre não será
relegada lá para trás, nem a parte mais
pública será colocada em lugar esconso,
nem a parte privada em lugar
devassado."123

Quando fornece diretrizes para a casa de vila, Alberti retoma essa setorização e já a reapresenta com a configuração tripartida que permanece até os dias atuais: a casa deve ter três zonas, uma para receber (social), uma para repousar (íntima) e uma para os bens de que ela se serve (serviços). o autor também lista as principais partes da casa, estabelecendo uma hierarquia entre os espaços mais importantes do edifício residencial, começando pela loggia que recebe o visitante e funciona como um filtro entre o

22 Cf. Burns (1998, p.121).

123 Alberti, Livro I, Cap. IX (2011a, p.170-171). 
exterior e o interior: primeiro o átrio ${ }^{124}$ (sinus), depois a sala de refeições, logo depois os quartos e, por fim, a sala de estar.

Embora seja feito um paralelo aqui sobre a setorização proposta por Alberti e as zonas da tripartição residencial burguesa, é importante esclarecer que essa divisão ainda é incipiente e se desenvolve completamente somente no decorrer do século XIX ${ }^{125}$. Isso significa que, ainda que na residência já fosse percebida a utilização dos cômodos em três zonas, uma pública de representação, uma privada para intimidade familiar e uma terceira para os serviços, frequentemente um mesmo cômodo, dependendo da forma como fosse utilizado, pertencia a mais de uma delas.

A organização residencial predominante nessa época, ainda que crescessem o espaço interno e a quantidade de quartos nas residências burguesas, não rompia completamente com a divisão sala (onde estar e receber) e quarto (repousar). Foi nessa época que começaram a surgir outros cômodos com usos específicos, nas residências dos mais ricos: entradas, antecâmaras, salas de armas, loggie, pátio, entre outros $^{126}$.

Ainda que não se possa falar em privacidade e intimidade, conceitos que só foram solidificados séculos mais tarde, já se percebe no discurso de Alberti um início dessas preocupações em diversas passagens. Já que as casas sempre tinham cômodos destinados a hospedar visitantes, ele recomenda cuidado com a localização dos cômodos destinados ao uso dessas pessoas que não fazem parte da família, como as como ao falar das salas de jantar, despensas e outras dependências: "serão diferenciadas para que se evite que a convivência entre hóspedes e moradores diminua a estes a dignidade, o bem estar e o prazer, e àqueles acrescente atrevimento. "127

Apesar disso, deve-se ter em consideração que como família, Alberti entendia um grupo de pessoas bastante amplo: "A família é constituida pelo homem, pela esposa, pelos seus

\footnotetext{
124 A tradução consultada emprega o termo 'corte', mas Bártoli (1565, p124) emprega 'cortile'. Giontella (2010, p.198) lamenta a falta de um termo em italiano que faça jus ao termo latino com significado de átrio central, quase simbolizando o coração da casa, onde encontrar refúgio.

125 Cf. TRAMONTANO, M. Paris-São Paulo-Tokyo: novos modos de vida, novos espaços de morar. Tese de doutorado. São Paulo: FAUUSP, 1998.

126 La Ronciére (2009, p.184).

127 Alberti, Livro V, Cap. II (2011a, p.321).
} 
filhos e pelos seus pais, e por aqueles que habitam com eles para seu serviço, como os intendentes, os criados, os servos; além disso, a família não exclui os hóspedes." ${ }^{128}$. Essa família conjugal múltipla era uma realidade na Toscana do século XVI, sobretudo entre os ricos moradores de propriedades rurais, mas a inclusão dos servos e criados nessa família era uma particularidade do texto de Alberti ${ }^{129}$.

Apesar disso, os administradores, empregados e servos terão aposentos separados dos senhores e próximos aos locais onde desempenham seus afazeres. Somente os criados e criadas não devem estar próximos dos seus locais de trabalho, de modo que possam ouvir e atender prontamente os chamados dos patrões.

Outra indicação de que começava a aparecer a noção de intimidade era a recomendação albertiana de que a esposa e o esposo dormissem em quartos separados, mas que se comunicassem por uma porta interna, de modo que pudessem transitar entre um e outro sem ser surpreendidos por outras pessoas.

Palladio, em seu discurso, expõe um modelo simplificado e bipartido de residência, onde existem partes principais e mais nobres, que devem ser expostas, e outras ignóbeis e feias, que estão a serviço das primeiras, tornando-as possíveis:

"Porque se como no corpo humano há
algumas partes nobres e belas e algumas
mais ignóbeis e feias, vemos no entanto
que aquelas têm destas enorme necessidade
e que sem elas não poderiam ficar, assim
também nas construços deve haver algumas
partes importantes e honradas, e outras
menos elegantes, sem as quais, porém,
aquelas não poderiam ficar livres e,
assim, perderiam parte de sua dignidade e
beleza. Mas assim como o Deus Bendito
ordenou estes nossos membros, de modo que
os mais belos estejam em lugares mais
expostos a serem vistos e os menos dignos
em lugares escondidos, assim também nós,
ao construir, colocaremos as partes
principais e importantes em lugares
descobertos e as menos belas em lugares
mais escondidos aos nossos olhos quanto
possivel porque neles serão postas as

28 Alberti, Livro V, Cap. XVII (2011a, p.361).

129 La Ronciére (2009, p.168-170). 
feiúras da casa e todas as coisas que
poderão trazer problemas e enfear as
partes mais belas." 130

Num primeiro momento, essa classificação paladiana pode induzir a entender a setorização em somente duas zonas, uma pública e bela e outra privada e feia, o que é curioso, tendo em vista que quase cem anos antes Alberti já tivesse apresentado uma tripartição da residência a partir de suas funções.

Pouco depois, Palladio dá indícios de que nessa sua classificação estão presentes as três zonas de Alberti, pois, em grande parte de suas casas de vila o zoneamento acontece tanto horizontalmente quanto verticalmente:

"Por isso, aconselho que na parte mais
baixa da construção, que faço
parcialmente enterrada, estejam dispostas
as adegas, os depósitos de lenha, as
despensas, as cozinhas, os refeitórios,
os lugares de lixiviar ou alvejar, os
fornos e outros similares, que ao uso
quotidiano são necessários. Daí provêm
duas comodidades: uma é que a parte de
cima fica toda livre e a outra, não menos
importante, é que a dita ordem de cima
torna-se sã para ser habitada, estando
seu pavimento longe da umidade da terra;
além disso, alçando-se, tem bela graça ao
ser vista e ao se olhar para fora. "131

Palladio elenca as partes das casas que seriam principais e mais dignas - loggie, salas, pátios, cômodos magníficos e escadas amplas, luminosas e fáceis de subir - e as partes que seriam pequenas e feias - lugares acomodados a serviço das partes maiores - afirmando, entretanto, que todas elas são necessárias e devem ser bem cuidadas.

A semelhança com as partes enumeradas por Alberti é grande e a maior inovação paladiana é a inclusão das escadas entre esses cômodos principais. Enquanto Alberti afirma que elas constituem um obstáculo ao desenho do edifício e sugere que sejam evitadas sempre que possível, Palladio lhes dedica um capítulo bastante extenso, se comparado com os demais, detalhando o projeto de escadas e apresentando quatro páginas com exemplos (Figura 26).

130 Palladio, Livro II, Cap. II (2009, p.71-72). Grifo nosso.
${ }^{131}$ Palladio, Livro II, Cap. II $(2009, \mathrm{p} .71-72)$. Grifo nosso. 


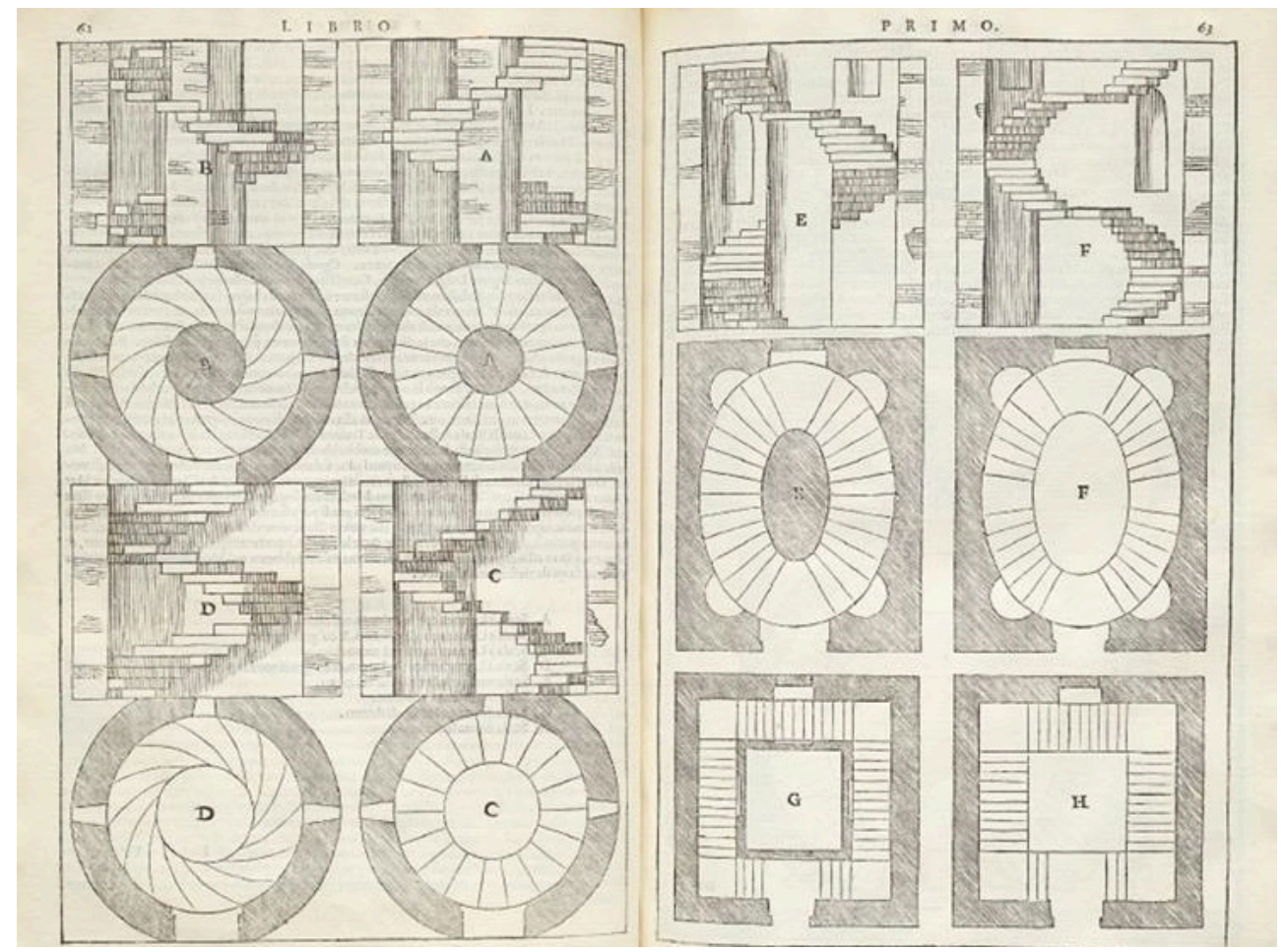

Figura 26 -Duas das páginas do tratado onde Palladio apresenta modelos de escadas (inf.). Fonte: Palladio (1570, Livro I, p.62-63). 

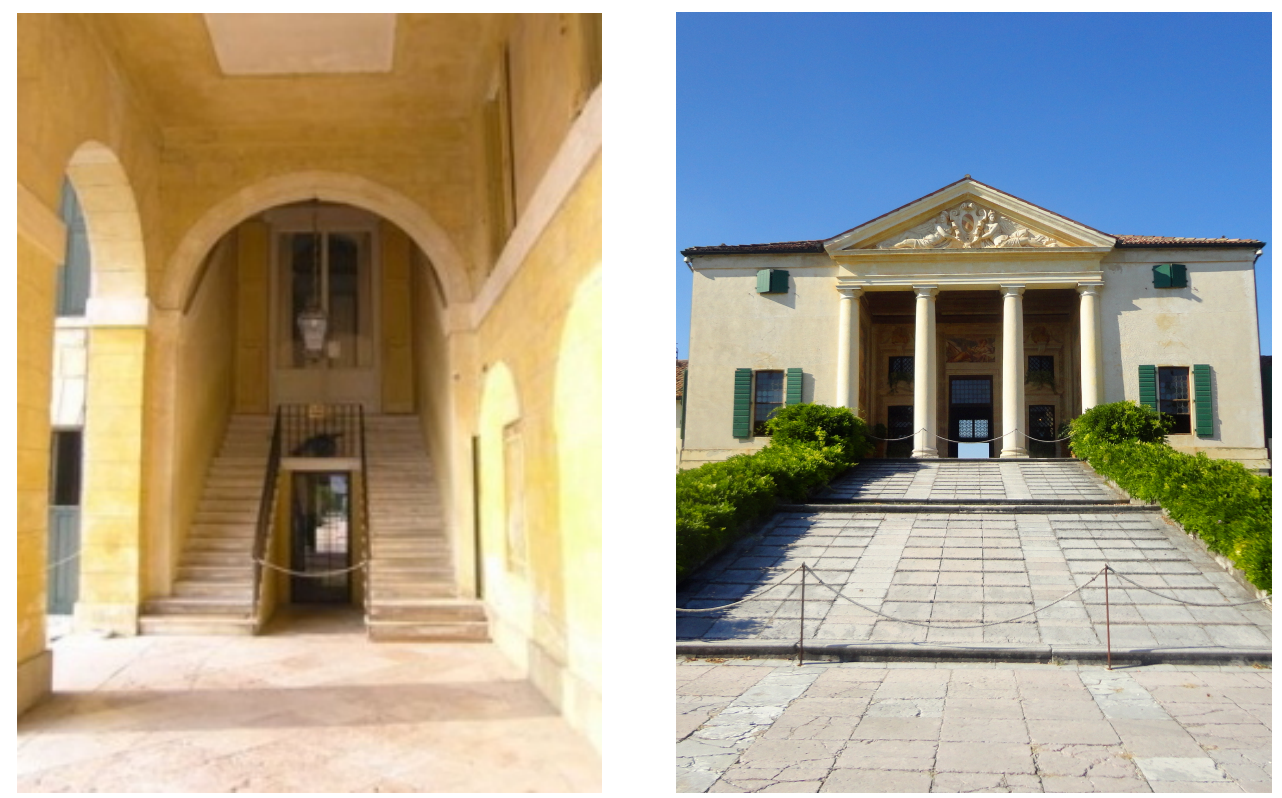

Figura 27 - Escadas de acesso ao edifício residencial da Villa Barbaro (esq). Figura 28 - Rampa de acesso ao edifício residencial da Villa Emo (dir). 
Pode-se ver nas Figuras 27 e 28 duas vilas em que a escada possui papel de destaque. Na Villa Barbaro tem-se uma escada assumindo papel de destaque de forma bastante particular, pois, diferentemente do que ocorre em quase todas vilas paladianas, aqui a entrada não se dá por uma loggia frontal, mas por dentro da loggia lateral. Sendo assim, cabe à escada o papel de conduzir o visitante ao nível do piano nobile (Figura 27). Já na Villa Emo (Fig 28) no lugar da escada de acesso à loggia frontal, tem-se uma grande rampa, que desempenha esse papel de conduzir o visitante ao edifício que está como que sobre um pedestal.

Esse tipo de solução não aparece no discurso de Alberti, que no caso das vilas aconselha a evitar o uso de escadas e desníveis, optando por construções térreas:

"Contribuirá para a comodidade e ainda
para a beleza dos edifícios se não houver
necessidade de subir ou descer mais do
que é razoável. E tem razão a advertência
daqueles que afirmam que as escadas são
um elemento perturbador dos edifícios.
Vejo que os Antigos chamaram muito a
atença para o atravancamento que elas
provocam. Mas, na casa de campo, nenhuma
necessidade obriga a sobrepor edifícios
uns aos outros."132

Porém, caso seja necessário projetar escadas ${ }^{133}$, ele recomenda que elas sejam posicionadas onde provoquem menos desvantagem ao edifício, e que sejam amplas, espaçosas e bem iluminadas, mas em seguida volta a aconselhar que elas sejam evitadas: "Em todo edifício quanto menos forem as escadas e quanto menos área ocuparem, tanto melhor será."134

Observando-se os projetos de vilas que Palladio inclui no tratado, fica evidente a dificuldade de se estabelecer uma comparação tão direta e linear entre sua proposta de setorização e aquela de Alberti, sobretudo ao considerar somente o que foi escrito. Isso muda quando se observam os projetos paladianos, que são fundamentais para completar e esclarecer sua proposta, formando com ela um conjunto indissociável.

Ao mesmo tempo que entre os cômodos ignóbeis e feios pode estar situada a zona de serviços, sempre que possível

\footnotetext{
132 Alberti, Livro IX, Cap. II (2011a, p.580).

133 Entre as escadas ele também inclui as rampas.

134 Alberti, Livro I, Cap. XIII (2011a, p.184).
} 
excluída do pavimento principal da residência, também podem aparecer compartimentos da zona íntima, como as latrinas. Entre os cômodos nobres e belos são facilmente identificáveis aqueles que compõem a zona social, ocupando o eixo central da residência e ganhando destaque na composição do espaço interno, mas também pode estar uma parte da zona íntima, como algumas salas e quartos.

Muito além da organização de elementos de arquitetura e do estabelecimento de um zoneamento de funções, ambos arquitetos falam de elementos de composição, propondo a criação de percursos onde, como afirma Martinez"135, "cada espaço está desenhado em si mesmo e também como parte de uma sequência em um trecho determinado da mesma.".

Enquanto Alberti descreve uma sequência de cômodos e discute as relações entre eles, Palladio expõe projetos que demonstram diferentes experimentações. Cada um dos cômodos é projetado para ser completo e independente dos demais, mas também para ser usado e referenciado em conjunto com eles.

As vilas de Palladio são concebidas sempre como se suas partes fossem dispostas simetricamente em relação a uma espinha dorsal ${ }^{136}$, retomando a tradição vêneta de colocar ao centro um eixo formado pelo alinhamento dos espaços principais e posicionando lateralmente conjuntos simétricos de compartimentos auxiliares.

São, assim, formados os chamados apartamentos, que são conjuntos com a mesma quantidade de cômodos - grandes, médios e pequenos - colocados um ao lado do outro para servir-se reciprocamente. Recomendação semelhante já havia feito Alberti, ao falar sobre a compartimentação dos edifícios privados: "uns elementos são agradáveis se forem maiores, outros hão-de conferir graça se forem mais pequenos, outros consegui-la-ão pelo seu tamanho mediano." ${ }^{137}$.

\footnotetext{
${ }^{135}$ Cf. Martinez (2000, p.177). O autor opõe os elementos de arquitetura como sendo as diversas partes do edifício - como janelas, portas, e os demais limites do edifício, aos elementos de composição - que são características mais conceituais, como os espaços obtidos por meio desses limites.

${ }_{136}$ Cf. Ackerman (1996, p.28).

137 Alberti, Livro I, Cap. IX (2011a, p.172).
} 

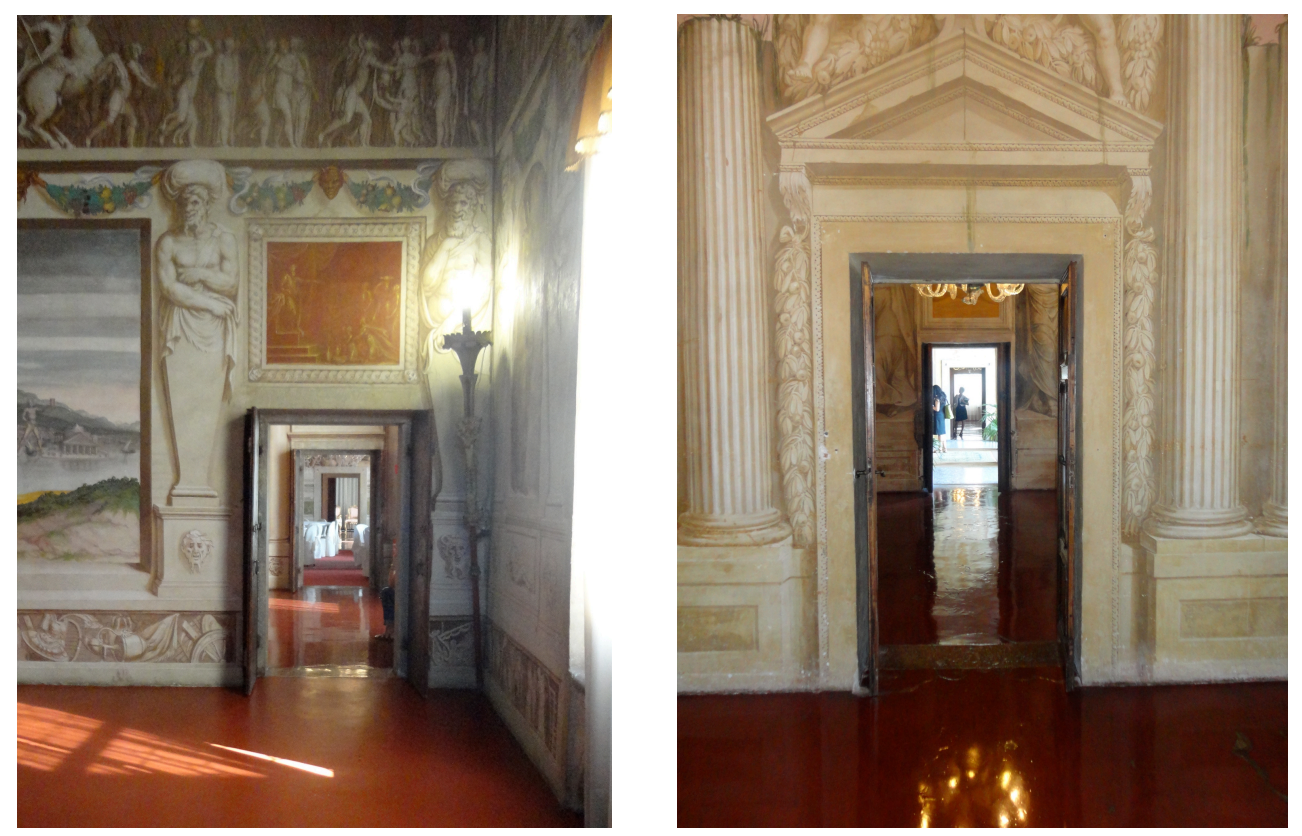

Figura 29 - Vista a partir da sala principal da Villa Godi, com as aberturas internas alinhadas (esq). Figura $\mathbf{3 0}$ - Vista a partir de um dos cômodos internos da Villa Godi, com aberturas internas e externas alinhadas (dir). 
Mas Palladio vai além, com sugestões de usos e subdivisões para esses cômodos, que, quando pequenos poderão ser subdivididos e utilizados pequenos escritórios, bibliotecas, depósitos de equipamentos de cavalgadura e outros envoltórios, "dos quais temos necessidade diariamente, e não é bom que fiquem nos cômodos em que se dorme, se come ou se recebem forasteiros" ${ }^{138}$. Percebe-se que esses apartamentos podem ser tanto públicos quanto privados, dependendo da ocasião e do modo como são utilizados.

Por serem posicionados à margem do eixo principal, esses apartamentos têm papel mais discreto na configuração do espaço principal. Num primeiro momento participam dele por estabelecerem seus limites, mas podem facilmente passar a integrá-lo a partir da prática paladiana de alinhar as aberturas externas e internas, que cria um percurso tanto para a luz que penetra no edifício quanto para seus visitantes (Figuras 29 e 30).

A sucessão de espaços com suas portas alinhadas cria um eixo de circulação, mas por dentro dos cômodos e, portanto, ainda muito distante dos corredores, que só viriam séculos mais tarde. Por outro lado, os vestíbulos alongados que Palladio inclui em diversas vilas não são espaços autônomos e independentes dos cômodos com que se comunicam, mas também áreas de passagem que, ainda que de forma bastante incipiente, já se aproximam um pouco dos cômodos destinados à circulação e, como observou Lucaas ${ }^{139}$, podem ter sido "os primeiros passos na direção das mudanças profundas que ocorreriam paulatinamente na arquitetura dos séculos seguintes." .

Tendo sempre em mente a produtividade da vila, Alberti não limita suas orientações sobre a setorização à residência patronal, mas também abordam a implantação dos demais edifícios no interior da vila. Ele indica as funções das instalações destinadas aos servos da gleba: produção, colheita e armazenamento dos produtos, exceto quando se entende que esse armazenamento seja atribuição dos senhores e de suas residências, como acontecia, por exemplo, nos celeiros que Palladio colocava sobre o piano nobile de muitas de suas vilas.

138 Palladio, Livro II, Cap. II (2009, p.72).
139 Cf. Lucaas (2011). 
Quanto à localização dessas instalações, destinadas à residência dos servos e manufatura da produção agrícola, ele faz a seguinte recomendação:

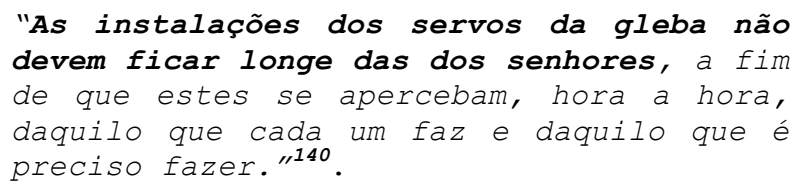

Somando-se a isso as recomendações albertianas para localização da casa de vila na propriedade, tem-se um conjunto de indicações que parece antecipar o binômio barquessa/galeria, de Palladio:

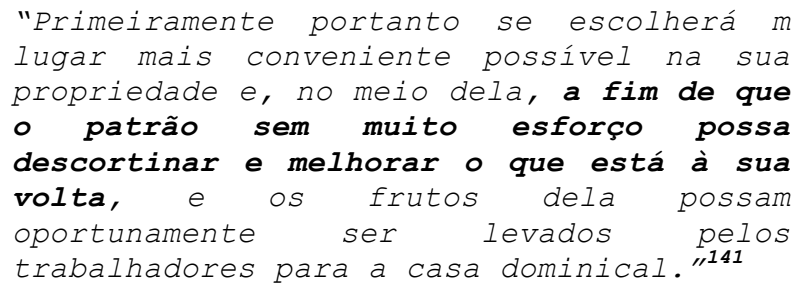

As diretrizes paladianas, encontradas no capítulo XIII, do Segundo Livro, vão na mesma direção, primeiramente com a determinação dos dois tipos de edifícios necessários nas vilas, um para residência do patrão e outro para "governar e vigiar a colheita e os animais da Villa." 142, depois orientando quanto à relação entre eles:

"As coberturas para as coisas de Villa se
farão considerando a colheita e os
animais, e unidas à casa do patrão, de
modo que em qualquer lugar se possa andar
ao coberto, de modo que nem as chuvas nem
os sóis ardentes do verão sejam um
incômodo ao ir ver seus negócios, o que
será de grandíssima utilidade para deixar
ao coberto lenha e outras tantas
infinitas coisas da Villa que se
estragariam com as chuvas e com o sol,
além do que esses pórticos trazem muito
ornamento." ${ }^{443}$

A riqueza de possibilidades com que Palladio faz a ligação entre os dois edifícios é notável. A loggia assume papel de destaque nessa relação, sendo muitas vezes

140 Alberti, Livro V, Cap. XV (2011a, p.355).

141 Palladio Livro II, Cap. XII (2009, p.113).

142 Palladio Livro II, Cap. XIII (2009, p.114).

143 Palladio Livro II, Cap. XIII (2009, p.114). 
responsável por articular esses dois volumes e ganhando destaque na composição do conjunto, como é indicado pelo próprio autor ao final do trecho citado acima - em negrito em que recomenda a proximidade entre os dois. Para a vila são, portanto, propostos três edifícios: a casa de vila, a barquessa e a arcada (loggia).

\section{Compartimentação e dimensionamento}

No tratado de Palladio, a compartimentação dos edifícios é apresentada de forma bastante sistemática e rigorosa, com o edifício principal organizado em seis partes principais: sala central, cômodos laterais (stanze), galeria (loggia), escada (interna e externa), Pronao, serviços (semienterrado e celeiro).

Inicialmente serão apresentadas aqui as diretrizes específicas para cada compartimento e depois a síntese das proporções indicadas para os compartimentos e as relações entre as partes e o todo.

\section{Loggia}

No capítulo em que fala sobre as loggie, Palladio indica que elas normalmente são feitas aos pares, uma na fachada frontal e uma na posterior, ou nas laterais da edificação, podendo ser feita somente uma no meio. Normalmente são utilizadas para refeições e outros deleites, e seu tamanho varia de acordo com a dimensão e a utilidade da construção, "mas geralmente não se farão menos largas que dez pés nem mais que vinte"144.

Alberti, em seu tratado, não fala especificamente em loggie, mas no conjunto de pórtico e vestíbulo, que terão mais pompa se forem acompanhados de um portal, voltados para uma rua importante e construídos com dignidade. Ele também aconselha que seja voltado para o sul, para evitar a insolação do Norte no verão e receber aquela proveniente do Sul, no inverno.

Para os dois autores, esse é um espaço de grande importância por identificar a entrada do edifício e fazer a transição entre o interior e o exterior.

144 Palladio, Livro I, Cap. XXI (2009, p.52). 


\section{O seio da casa}

Nos dois tratados o cômodo central aparece como o lugar mais importante da casa. Para Alberti o átrio é como se fosse - seio da casa, tanto na residência do príncipe quanto nas casas dos homens livres:

"será a parte mais importante, para a
qual convergem, como se fosse a praça
pública do edificio, todos os membros
menores, e a partir da qual serão
devidamente distribuidos não só os
acessos mais cômodos, mas também as
convenientes aberturas de iluminação. Por
isso, é óbvio que cada um deseja ter como
'seio da casa' um espaço amplo, aberto,
digno, acessivel."145

Palladio escreve sobre o tema nos dois primeiros livros do tratado. Primeiramente, ele aborda o tema no capítulo em que trata 'Das loggie, das entradas, das salas e dos quartos; e da forma deles', com uma argumentação muito próxima da que foi destacada acima: "Têm, além disso, todas as casas bem ordenadas no meio e na sua mais bela parte alguns lugares aos quais correspondem e nos quais desembocam todos os outros. Estes na parte de baixo chamam-se vulgarmente Entradas e na de cima, Salas. São como lugares públicos"146.

Tanto o átrio albertiano quanto as salas de Palladio são comparados com praças e referidos como ponto de convergência e distribuição, simultaneamente, o que é papel recorrente nos pátios e átrios da tradição clássica ${ }^{147}$. Apesar disso, chama atenção a semelhança entre os dois textos, que fica mais evidente nos trechos destacados em negrito.

Pode-se ver a importância do tema para Palladio pela quantidade de informações que ele fornece para o projeto dos átrios. Além do que apresenta no Livro I, sobre as Entradas e Salas, ele volta ao tema em quatro capítulos no Livro II, quatro sobre os átrios e três sobre as salas dos Antigos.

o destaque dado por Palladio aos átrios no tratado é equivalente à importância que eles ganham em seus projetos, é a partir deles que seus edifícios se organizam: "É o elemento central da composição, a partir do qual são organizados seus

\footnotetext{
145 Alberti, Livro V, Cap. XVII (2011a, p.361). Grifo nosso.

146 Palladio, Livro I, Cap. XXI (2009, p.52). Grifo nosso.

147 Martinez (2000) indica que na tradição clássica, os espaços principais podem ser focais, direcionais, ou as duas coisas simultaneamente.
} 
esquemas planimétricos e altimétricos, de acordo com as necessidades e caráter de cada obra."148.

Quando apresenta seus projetos, Palladio chama esse cômodo central de sala e não de átrio, o que provavelmente está relacionado à tradição regional: na Toscana, os palácios urbanos que se organizavam em torno de um pátio ou átrio, enquanto no Vêneto esse pátio dá lugar a uma sala alongada ${ }^{149}$.

Após concluir o capítulo sobre os átrios, Palladio passa a falar das Salas e Entradas, cômodos que para ele eram equivalentes ao átrio dos Antigos. Os dois nomes diferentes estavam relacionados somente à diferença de localização, as Entradas no piso de baixo e as Salas no superior.

Quando situadas na parte de baixo são chamadas Entradas, por serem a primeira parte da casa com que os visitantes têm contato, após passarem pela loggia, servindo como local de espera para aqueles que devem aguardar o proprietário da vila.

Na parte de cima das residências esse cômodo central é chamado de Sala, um local destinado à realização de festas, banquetes, peças de teatro, casamentos, etc., devendo, por isso, ter dimensões adequadas para acomodar uma grande quantidade de pessoas. Alberti também fala sobre isso, inclusive atribuindo finalidades semelhantes: "o salão que, segundo julgo, deriva de saltar, porque nele se celebra a alegria das bodas de casamento e dos convivas"150.

Para o dimensionamento das salas, Palladio recomenda que se mantenha uma razão onde o comprimento não ultrapasse a duas vezes a medida da largura, "mas quanto mais se aproximarem do quadrado mais serão louváveis e cômodos"151.

Quando começa a apresentar as partes que considera mais importantes nas casas dos antigos, Palladio faz a seguinte observação "e porque nelas o Átrio era uma parte nobilíssima, falarei primeiro dos Átrios e, em sequência, dos lugares a ele acrescentados; depois irei às salas"152.

Ele começa elencando os diferentes tipos de átrio descritos por Vitruvio: Toscano, de quatro colunas, Coríntio,

48 Cf. Barbosa (2005, p.98).

149 Cf. Lucaas (2011).

150 Krüger (2011, p.320) observa que em latim, saltare significa dançar.

151 Palladio, Livro I, Cap. XXI (2009, p.52).

152 Palladio, Livro II, Cap. IV (2009, p.92). 
Testugginato ${ }^{153}$ e Descoberto e depois descreve os quatro primeiros e suas proporções, com o uso de desenhos em planta e em corte onde insere suas dimensões principais. Da mesma forma ele procede quanto aos lugares que chama de 'acrescentados ao átrio', que são: o Vestíbulo, que é a loggia que o precede; o Tablino, uma pequena sala entre o Átrio e o pátio central; e o Peristilo, que é esse pátio central cercado por colunatas ${ }^{154}$.

No átrio Toscano, a razão entre a largura e o comprimento é de $2: 3$. O Tablino desse átrio é quadrado e suas dimensões são iguais a $2 / 5$ da largura do átrio. O Peristilo terá comprimento $1 / 3$ maior que a largura.

O átrio de quatro colunas possui razão entre largura e comprimento igual a 3:5. A soma das duas alas laterais (indicadas pela letra $H$ na Figura 31) é igual a $1 / 4$ do comprimento do átrio. O Tablino tem largura e comprimento iguais à metade da largura do átrio.

o átrio coríntio possui o comprimento igual à largura multiplicada por $\sqrt{ } 2$. A soma das alas é igual a $1 / 3$ do comprimento. Para ilustrar esse tipo de átrio Palladio usa o projeto realizado para o Convento dela Carità, em Veneza, que é assimilado às casas dos antigos por ser residência dos Cônegos Regulares (Figuras 32 e 33).

Ao falar sobre o átrio testugginato, Palladio começa fazendo um alerta acerca da dificuldade de compreender sua configuração a partir do texto de Vitruvio. Assim como no átrio coríntio, aqui o comprimento é igual à largura multiplicada por $\sqrt{ } 2$. A largura do Tablino é igual a 1/2,5 da largura do átrio. Os pórticos que circundam o Peristilo têm largura igual à altura de suas colunas.

\footnotetext{
153 Na versão em português o termo testugginato é mantido em italiano ao longo do texto, sendo grafado com fonte itálica. A tradução, apresentada em nota, é essa: "Testugginato, coberto com testudine. Testudine, telhado formado de quatro planos convergentes para o centro; coruchéu, telhado de pavilhão" (Palladio, 2009, p.332)

${ }_{154}$ Cf. Barbosa (2005, p.97).
} 


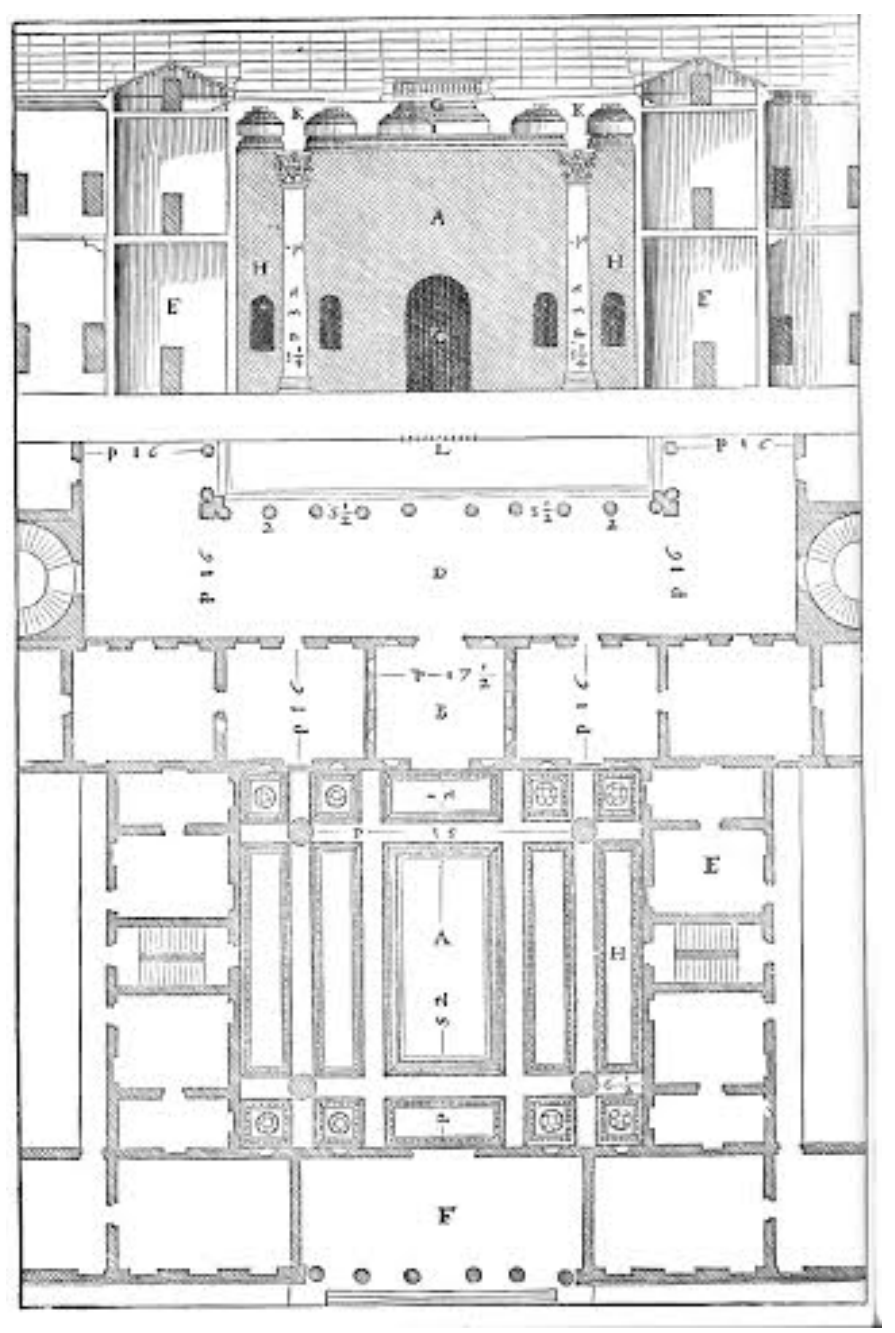

Figura 31 - Átrio de quatro colunas, corte e planta. Fonte: Palladio (2009, p.96). 

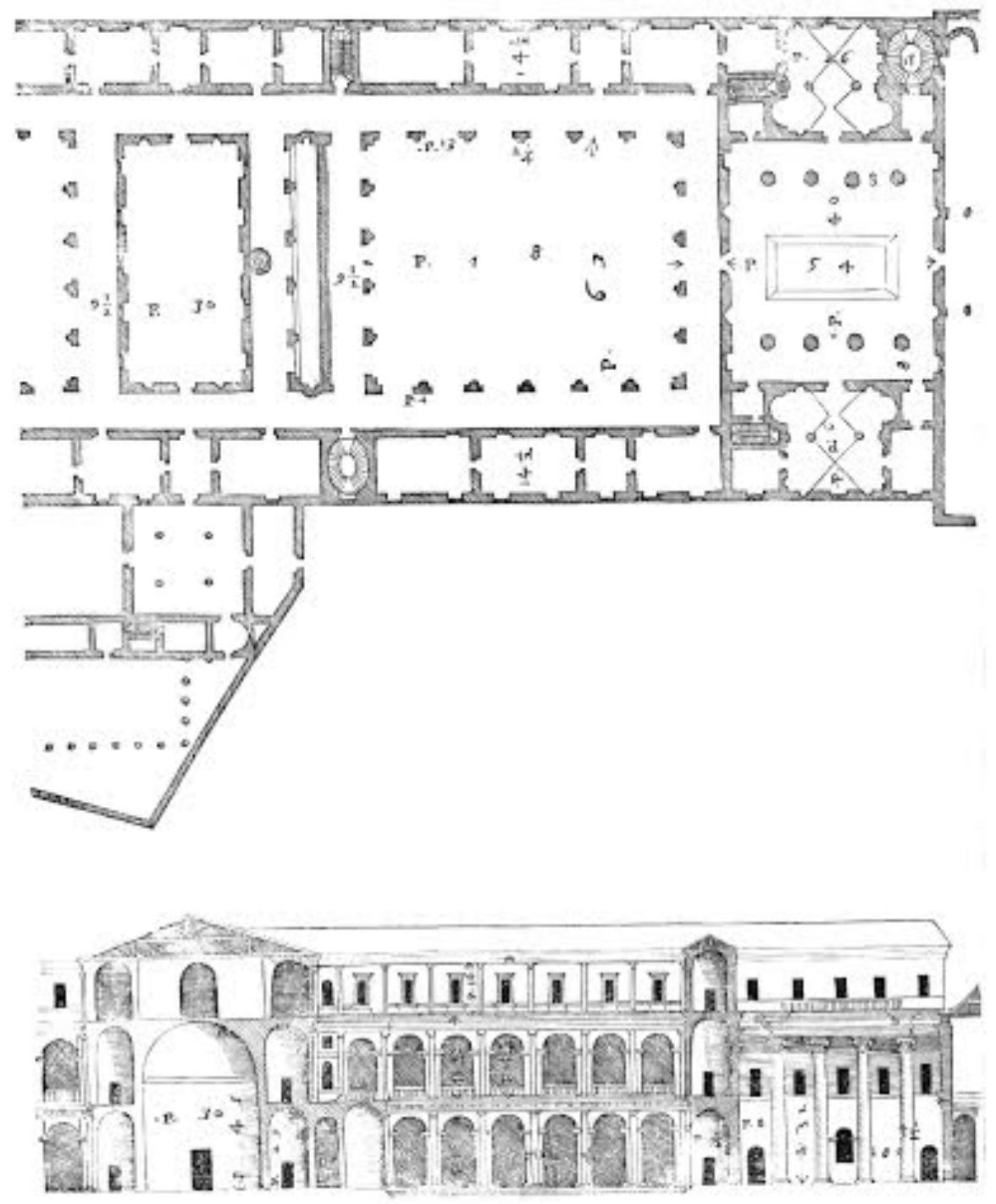

Figura 32 - Átrio coríntio no Convento della Carità, em Veneza. Palladio (2009, p.98). 


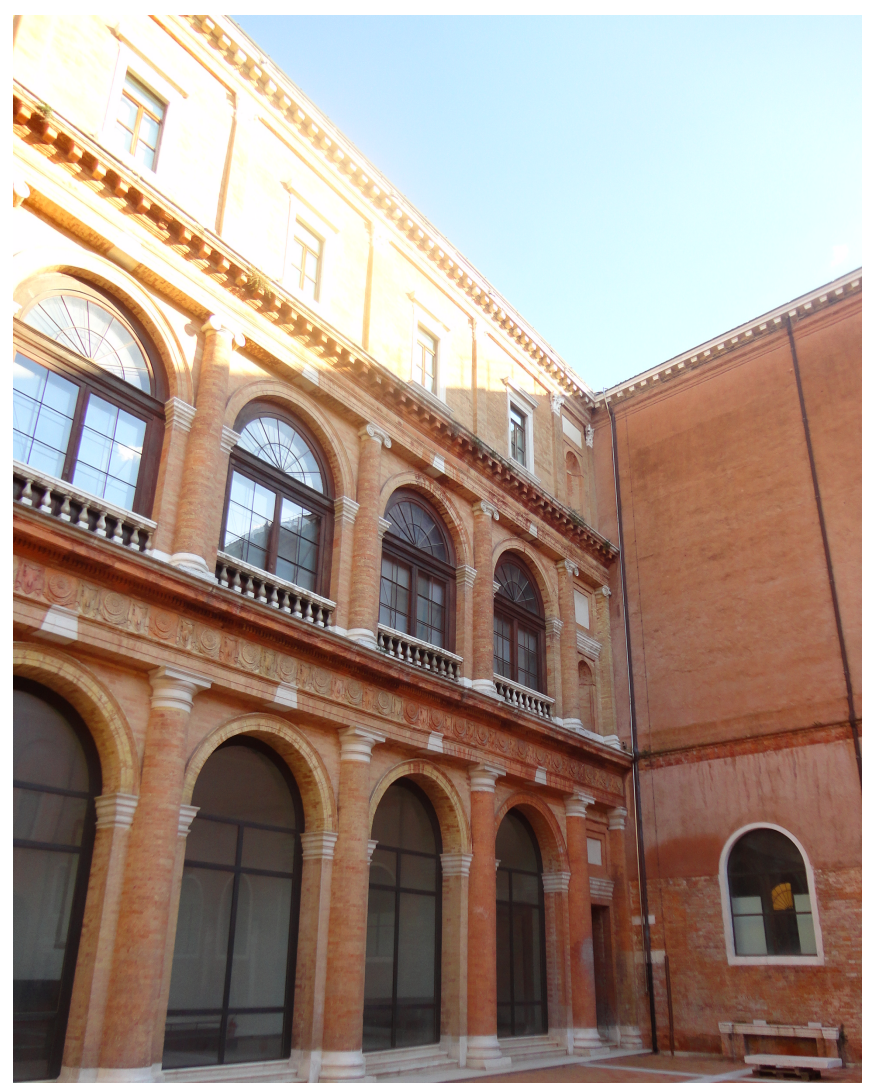

Figura 33 - Detalhe do Átrio coríntio do Convento della Carità, em Veneza. 
Das salas apresentadas, aquela que é mais frequentemente empregada nos projetos de vilas de Palladio é a chamada Sala de Quatro Colunas, ou Tetrastilo. Essa sala é quadrada e suas quatro colunas são posicionadas de forma a garantir a proporção entre a altura e a largura ${ }^{155}$, o que se dá porque a altura das colunas é igual à distância entre elas. As salas coríntias deveriam ter, preferencialmente, comprimento igual à medida da largura acrescida de $2 / 3$ (razão de 3:5). Nessa sala as colunas não são destacadas das paredes, como nas salas de quatro colunas, mas sendo ainda bastante próximas delas. Elas também podem ser colocadas diretamente no chão ou sobre pedestais.

As salas egípcias são associadas por Palladio às basílicas, o que sugere serem de dimensões maiores que as duas anteriores, e também mais ornamentadas: "Deviam ter essas salas uma grandeza admirável, seja pelo ornamento das colunas, seja por sua altura, já que o teto ultrapassava a cornija da segunda ordem e deviam ser muito cômodas quando aí se faziam festas ou banquetes."156

No texto de Alberti as salas recebem menor destaque, provavelmente devido à diferença de função que desempenham: salas de refeições, despensas e outras dependências, todas elas dimensionadas segundo as mesmas regras. Outros tipos de salas, como as de reuniões, são mencionados somente para as casas dos príncipes, enquanto nas casas dos homens livres as salas são somente essas três.

Para Alberti, sempre que possível deve-se ter duas ou até mais salas de refeições, uma para os hóspedes - que deve se abrir para o átrio, uma ou duas de uso da família, em lugar mais reservado e com diferentes orientações para uso de acordo com as diferentes estações do ano. Próximas às salas de refeições devem estar cozinha e despensa, "onde se guardem os restos da ceia, as louças e a toalha."157

Quando fala sobre as salas de refeições e reuniões dos príncipes, Alberti indica que elas devem ocupar o lugar mais digno da residência, um lugar elevado e com vista para o mar, colinas ou uma ampla paisagem ${ }^{158}$.

Palladio, Livro II, Cap. VIII (1570, p.36).

156 Palladio, Livro II, Cap. X (2009, p.109).

157 Alberti, Livro V, Cap. XVII (2011a, p.365).

158 Alberti retoma aqui orientações feitas no Capítulo IV do Livro I, sobre a escolha do lugar. 


\section{Stanze}

Quanto à disposição dos quartos, Palladio recomenda que sejam dispostos de maneira simétrica em relação à sala, por motivos estruturais. As formas recomendadas para os quartos são sete: circulares; quadrados; ou retangulares com comprimento correspondente à diagonal do quadrado; retangulares com comprimento igual a um quadro ${ }^{159}$ e um terço; ou um quadro e meio; ou um quadro e dois terços, ou de dois quadri.

Quando o teto dos quartos é feito em laje, o pé direito no térreo será igual à largura do cômodo, e no pavimento superior serão um sexto mais baixos que esses. Quando o teto dos quartos é feito em abóbada, "como costumam ser os da primeira ordem porque assim resultam mais belos e menos expostos aos incêndios" ${ }^{160}$, a altura dos quartos quadrados será de quatro terços do lado.

No caso de quartos retangulares, deve-se somar a largura e o comprimento e dividir o resultado da soma por dois, onde o quociente será a medida da altura. Também para quartos retangulares que terão teto em abóbada é apresentado um método gráfico para determinação da altura do pé direito. O cômodo será o retângulo 'abcd', com largura 'ac'='bd' e comprimento ' $\mathrm{ab} \mathrm{b}^{\prime}={ }^{\prime} \mathrm{cd}$ '. Somando-se largura e comprimento temse 'bf', onde ' $e$ ' será seu ponto médio. Traçando-se uma circunferência com centro em ' $e$ ', o ponto ' $g$ ' será onde essa circunferência encontrar o prolongamento de 'ac'. Por fim, a altura será igual a 'cg'. Para que essa altura seja encontrada numericamente, basta que sejam multiplicados o comprimento e a largura e depois extraída a raiz quadrada do produto.

Palladio apresenta outras formas de se obter alturas proporcionais à largura e ao comprimento dos quartos e conclui afirmando que há ainda outras alturas que "não são regidas por regra e destas haverá de se servir o Arquiteto segundo o seu juízo e segundo a necessidade"161.

\section{Aberturas}

Os dois autores dedicam um capítulo para falar sobre o projeto das aberturas. Enquanto Palladio entende como

\footnotetext{
159 Termo empregado na tradução do tratado em português, correspondendo ao lado do quadrado.

160 Palladio, Livro I, Cap. XXIII (2009, p.53).

161 Palladio, Livro I, Cap. XXIII (2009, p.54).
} 
aberturas as portas e janelas, Alberti inclui também entre elas os intercolúnios, as escadas ${ }^{162}$, poços, esgotos, respiradouros e chaminés.

Começando pelas portas, os dois autores falam que não há uma dimensão específica, mas que se deve adequá-las ao tamanho e à forma do edifício.

Para Alberti elas devem sempre guardar dois tipos de proporção entre a altura e a largura: devem ser sempre mais altas que largas. Quando se deseja portas mais altas, elas devem conter dois círculos tangentes (devem ter altura igual a duas vezes a largura) e quando se deseja portas mais baixas, elas devem ter altura igual à diagonal do quadrado cujo lado seja igual à largura inferior da porta.

As orientações de Palladio para dimensionamento das portas são mais amplas, começando pelo estabelecimento de uma relação com o pé-direito, resgatada do texto de Vitruvio ${ }^{163}$ : divide-se o pé-direito em três partes e meia, e a altura da porta será igual a duas dessas partes; sua largura será de uma parte menos $1 / 12$ da altura.

As proporções das portas para ambos os autores são diferentes, tendo-se duas portas com a mesma altura, aquela de Palladio será 1/12 mais estreita que a de Alberti.

Palladio ainda faz uma orientação específica para as portas dos quartos, que devem ter largura entre dois e três pés e altura entre 5 pés e 6,5 .

Para a determinação das quantidades e dimensionamento das janelas, Palladio recomenda que se observe o tamanho dos cômodos que serão iluminados, considerando uma margem de tolerância para que elas possam ser todas iguais em um mesmo pavimento. Elas não devem ser mais largas que $1 / 4$ nem mais estreitas que $1 / 5$ da largura do quarto. A altura deverá ser igual a duas vezes a largura mais $1 / 6$ e a cada pavimento que se sobe ela deverá ser $1 / 6$ mais baixa.

As orientações de Alberti para a determinação das dimensões das janelas também são diferentes das apresentadas por Palladio, para o florentino, elas não deverão ter largura maior que $1 / 7$ da parede que ocupam nem menor que $1 / 9$.

\footnotetext{
162 E tema, entretanto, ele não discute no mesmo capítulo que as portas e janelas, dedicando-lhe um capítulo inteiro, assim como Palladio,

${ }^{163}$ Vitruvio, Livro IV, Cap. 6, (2007, p.223-227).
} 
Para quartos de mesma largura, as janelas de Palladio serão mais largas que aquelas de Alberti.

Os dois autores recomendam que as aberturas sejam afastadas dos ângulos da construção para que a estabilidade do edifício não seja prejudicada, sobre o que Palladio ainda vai além, afirmando que as janelas de pavimentos diferentes devem ser todas alinhadas verticalmente "de modo que sobre o vão haja vão e sobre o cheio haja o cheio"164.

Por fim, uma última observação importante a respeito das diretrizes de Palladio, já mencionada no item onde foi discutida a setorização do edifício, é o alinhamento de todas as aberturas internas e externas, para que "estando numa parte da casa se poderá ver até a outra, o que traz graça e fresco no Verão e outras comodidades". Essa estratégia de manter as aberturas alinhadas permite também que os ambientes menores e sem aberturas no centro do edifício recebam iluminação, ainda que difusa e em menor intensidade que os demais.

\section{Proporções e harmonia}

Como foi discutido no início desse capítulo, o texto de Alberti não apresenta em uma sequência linear os diversos temas abordados e isso se repete com as orientações quanto à compartimentação das vilas. Foram encontradas orientações nos Livros I, IV e V - algumas já analisadas no início desse capítulo e outras que o serão a partir daqui, e também no Livro IX - essas, por serem genéricas para todos os compartimentos são apresentadas a seguir e depois comparadas com cada um dos itens apresentados.

No início do Livro IX, Alberti fornece ainda algumas diretrizes específicas para o dimensionamento e localização dos cômodos no interior das vilas.

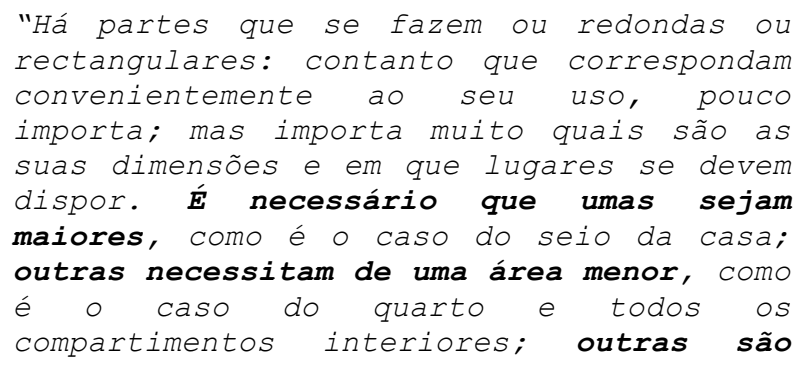

164 Palladio, Livro I, Cap. XXV (2009, p.55). 
médias, como é o caso da sala de jantar e do vestíbulo. "165

As recomendações de Alberti para a compartimentação dos edifícios aparecem distribuídas ao longo de todo o tratado. Algumas aparecem no Livro I, sobre o Delineamento, quando ele faz orientações gerais que servem para todos os tipos de edifícios, como a escolha do lugar onde se construir e o projeto de cada uma das partes da edificação: a determinação da área, da compartimentação, o desenho das paredes, a cobertura, as aberturas e as escadas. Outras são encontradas no Livro $V$, que trata do projeto de edifícios particulares.

No tratado, Alberti estabelece três princípios para se obter as justas proporções para todas as partes dos edifícios: número (numero), delimitação (finizione) e disposição (collocazione). A partir da fusão desses três princípios é que se teria a concinidade (concinnitas).

Sobre o número são feitas considerações acerca da observação dos números na natureza, das preferências dos antigos e de composições e decomposições feitas a partir deles. Primeiramente observa-se que são pares ou ímpares e, a partir daí, ele já estabelece uma relação com a estrutura do edifício e as aberturas na fachada:

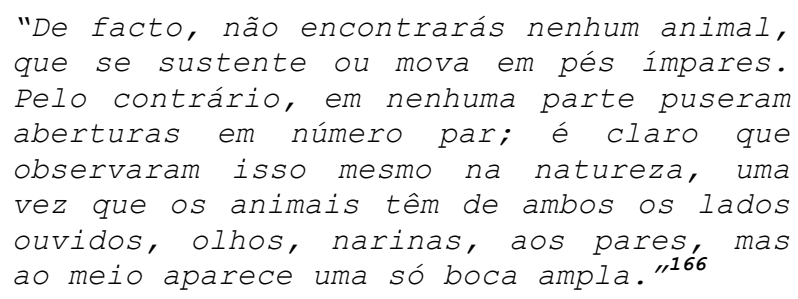

Em seguida, quando é abordado o conceito de delimitação, Alberti continua o discurso por alguma lei numérico-harmônica reguladora do universo, que relaciona com as proporções musicais:

"O segredo dessa harmonia residia em
algumas relaçoses numéricas cuja
encarnaça era oferecida por algumas leis
musicais transferíveis em leis
arquitetônicas.
transposição o antigo princípio segundo o
qual a variaça dos sons fosse
proporcional ao comprimento das cordas
musicais, de forma que resultava imediata

5 Alberti, Livro IX, Cap. III (2011a, p.582).

166 Alberti, Livro IX, Cap. V (2011a, p.595). 
a passagem de uma experiência acústicotemporal a outra ótico-espacial."167

As relações musicais apresentadas são aquelas que, para - autor, podem ser mais úteis ao trabalho do arquiteto, limitando-se a listar as proporções que seriam mais agradáveis, de acordo com a consonância e a harmonia musical, que também já haviam sido apresentadas por Vitruvio ${ }^{168}$ :

\begin{abstract}
"receberam designações numéricas, porque, atingindo a voz um determinado som, ela entra em flexão, muda e acaba por atingir uma quarta nota, chamada diatessaron, uma quinta, dita diapente, [uma sexta chamada diapason, uma oitava e uma meia, dita diapason e diatessaron, uma nona e meia, chamada diapason diapente, até uma décima segunda, dita disdiapason."
\end{abstract}

Alberti abstraiu desses conceitos vitruvianos as proporções: diapente - 3:2, diatessaron - 4:3, diapason 2:1, diapason-diapente - 3:1, disdiapason - 4:1, e ainda acrescentou tônus - 1/8. Ele, então, associou essas proporções aos lados de um quadrilátero, a fim de obter áreas proporcionais, "foram definidas nove áreas, subdivididas em três grupos com marcações de tamanhos precisos para que não houvesse qualquer margem de dúvida e o arquiteto/leitor pudesse aplicá-las facilmente em seus projetos"169, como pode ser visto na Figura 34.

A música, classificada como ciência matemática, fascinava os artistas do Renascimento. Essa associação entre arquitetura e música, portanto, visava uma aproximação entre a composição arquitetônica e a composição musical, assim como também ocorreu com arquitetura e a geometria e a aritmética ${ }^{170}$. Dessa forma, o prático Alberti deduz das harmonias musicais um sistema pelo qual, tendo-se um lado, obtêm-se o outro. E a partir desses dois pode-se obter o terceiro número, que determina a terceira dimensão ${ }^{171}$.

\footnotetext{
167 De Fusco (2003, p.180), tradução nossa do original em italiano: "Il segreto di questa armonia risiedeva in alcuni rapporti numerici la cui incarnazione era offerta da alcune leggi musicali trasferibili in leggi architettoniche. A favorire questa trasposizione era l'antico principio che la variazione dei suini fosse proporzionale alla lunghezza delle corde musicali, cosicché risultava immediato il passaggio da una esperienza acustico-temporale ad un'altra ottico-spaziale."

168 Pollio, Livro V, Cap. 4 (2007, p.256).

169 Cf. Rabelo (2007, p.35).

170 Cf. Wittkower (1952, p.115).

171 Cf. De Fusco (2003, p.183).
} 

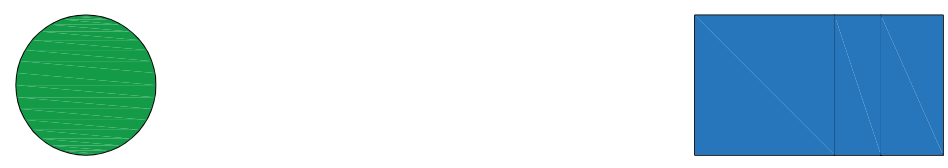

9:16
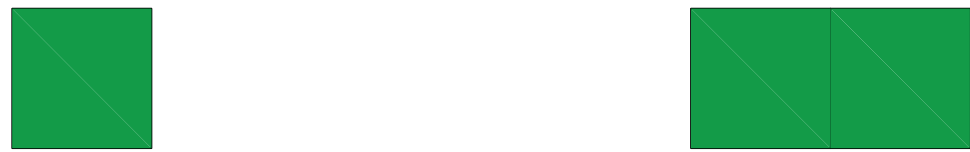

1:1

1:2

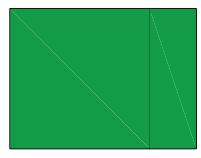

3:4

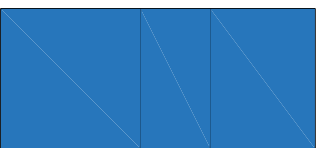

$4: 9$

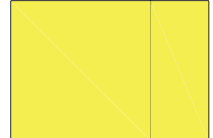

$1: 1,414 \ldots$

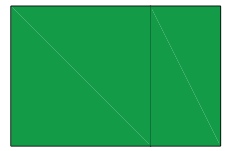

$2: 3$

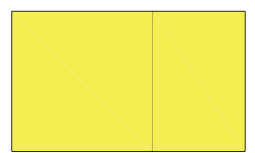

3:5

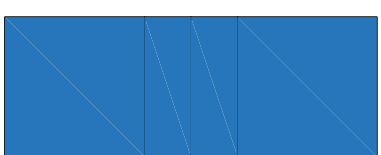

3:8

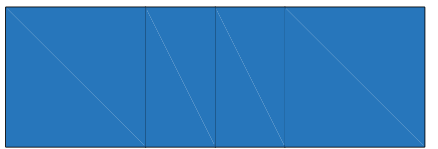

$1: 3$

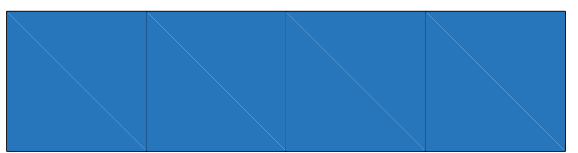

$1: 4$

Figura 34: Síntese das formas principais descritas por Alberti (Azul) e Palladio (amarelo) e aquelas que são referidas pelos dois autores (verdes). Fonte: Adaptado de Almeida (2005). 

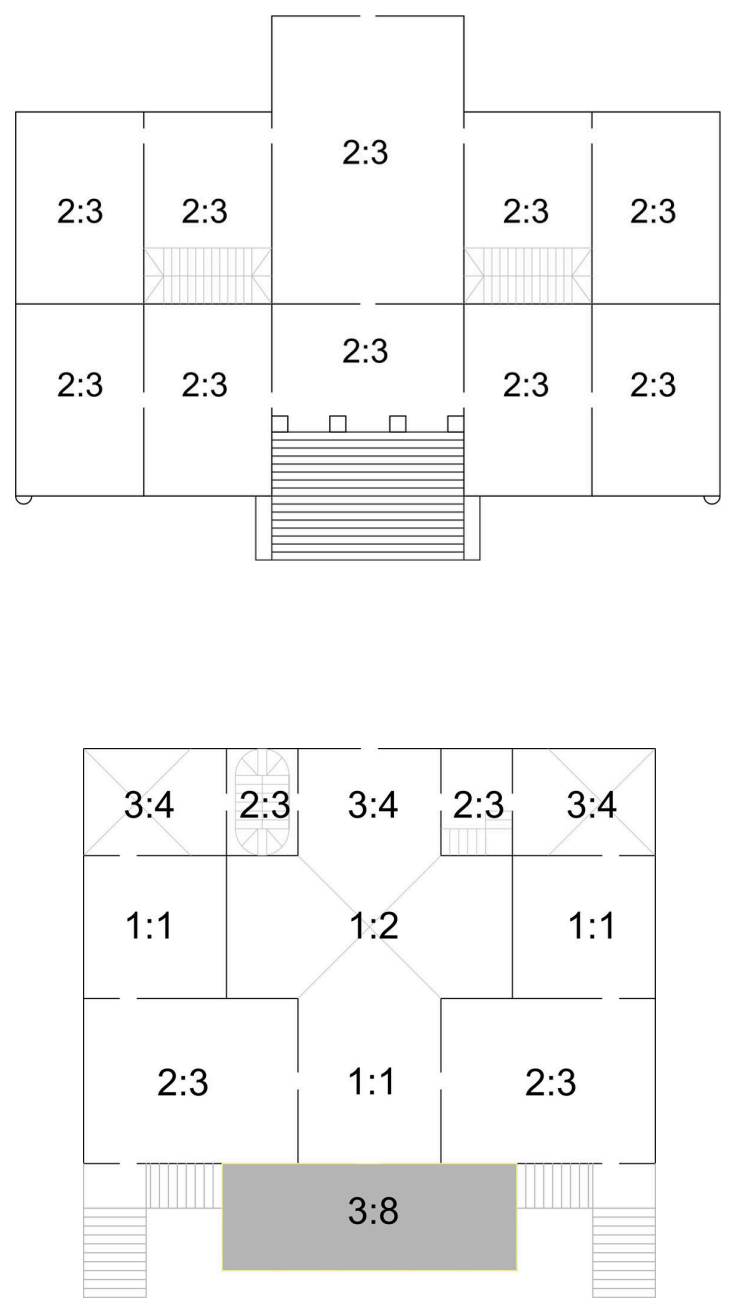

Figura 35 - Proporções utilizadas na composição da Villa Godi. Todos cômodos guardam as mesmas proporções entre suas dimensões. Figura 36 - Proporções utilizadas na compartimentação da Villa Foscari. Destaque para a relação de 3:8, segundo a qual é composta a loggia. 
Palladio, no decorrer de seu texto, estabelece sete formas proporcionais para seus cômodos, que podem ser vistas na Figura 33. A partir dessas sete proporções ele estabelece suas diretrizes projetuais para cada cômodo, e também para o todo, conjugando tanto inúmeras quanto geniais variações ${ }^{172}$.

Ainda que Palladio faça referência a somente algumas das proporções já recomendadas por Alberti, pode-se ver na Figura 34 que, na loggia destacada na planta da Villa Foscari, onde ele lança mão da proporção harmônica albertiana 3:8, além daquelas que formam seu próprio repertório teórico.

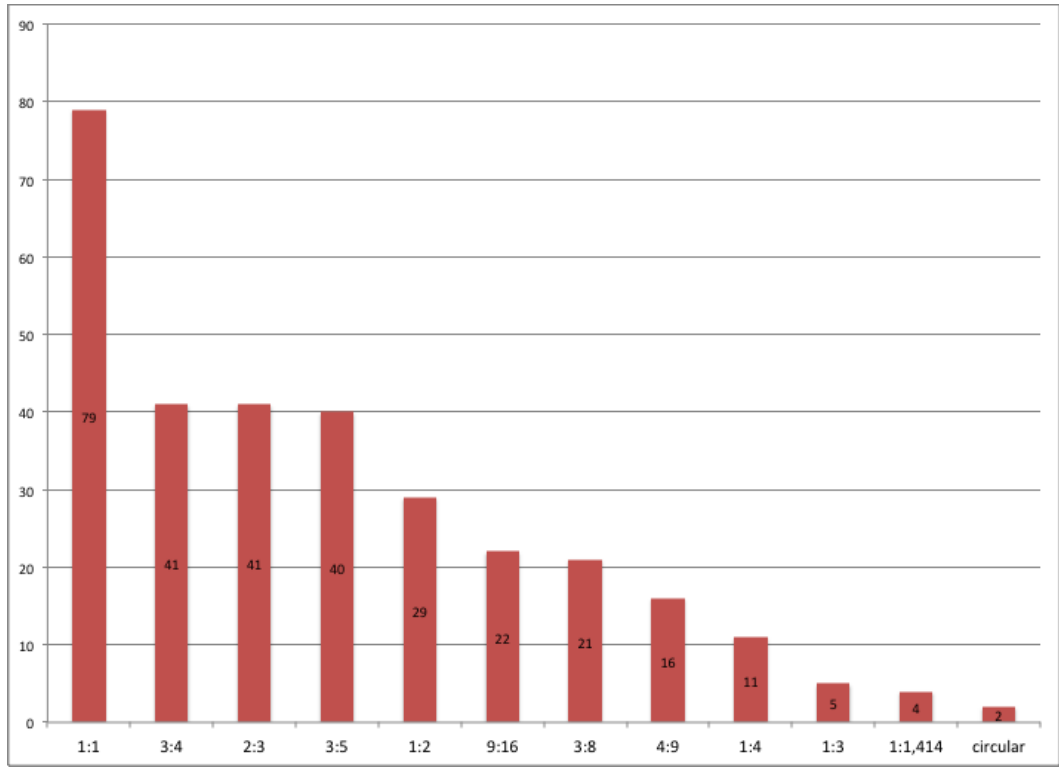

Gráfico 1 - No eixo vertical estão indicadas as proporções encontradas nos cômodos das casas de vila de Palladio e no vertical a quantidade de vezes que essas proporções se repetem.

Foram estudadas as proporções encontradas em cada uma das casas de vila que Palladio ${ }^{173}$ apresentou no tratado e, observando-se o gráfico 1 , pode-se perceber que as proporções albertianas como $9: 16,3: 8,4: 9,1: 4$ e $1 ; 3$ são mais frequentes que os paladianos retângulo áureo e forma circular.

o mesmo se repete ao considerar exclusivamente as proporções encontradas no corpo principal de cada uma das vilas, como pode ser visto no Gráfico 2. Nesse caso, a forma

\footnotetext{
172 Battilotti (2011, p.12). Tradução da autora, do italiano: "Esso si afferma come una costante soprattutto nei progetti per ville di Palladio, che saprà declinarne innumerevoli quanto geniali variazioni."

${ }^{173}$ Ver Apêndice B.
} 
que mais se repete é o quadrado, seguido pelo retângulo áureo, mas também são percebidas proporções albertianas como a $9: 16$.

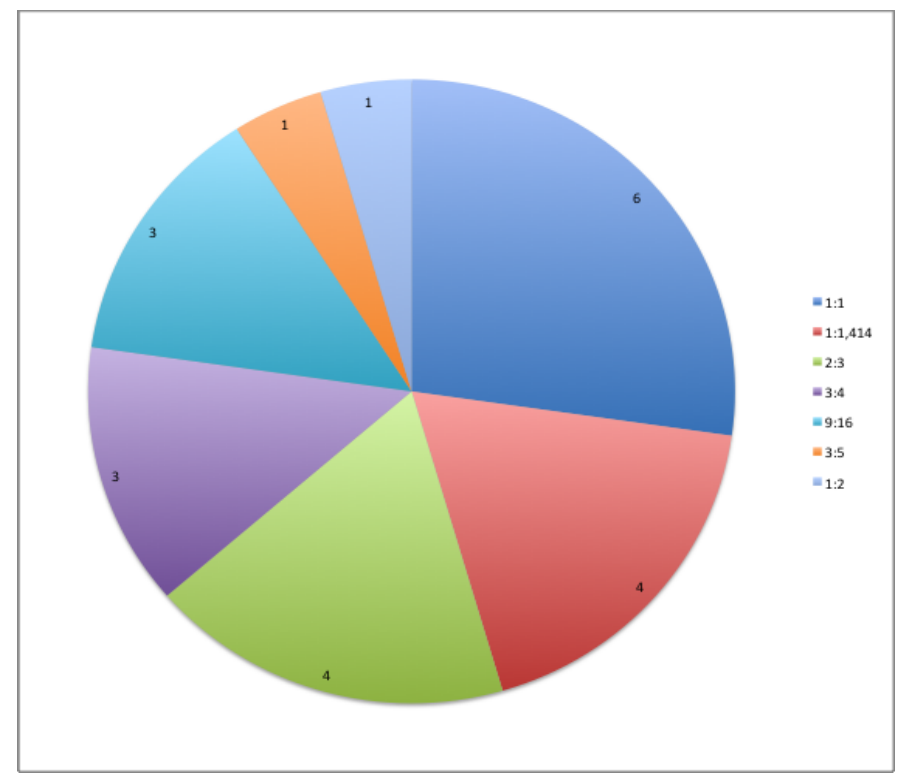

Gráfico 2 - Proporções encontradas no corpo principal das casas de vila que Palladio apresenta em seu tratado.

Alberti, após discorrer sobre a aplicação das proporções musicais na arquitetura, fala sobre o terceiro componente da concinidade, a disposição. Aqui, entretanto, ele não apresenta novas concepções, limitando-se a descrever brevemente o modo para que sejam obtidas a média aritmética, a média geométrica e a média musical, repetindo conceitos já apresentados ao falar da delimitação e das harmonias musicais.

Percebe-se que, embora Palladio não faça menção em seu texto a algumas orientações de Alberti, muitas vezes é possível encontrar a sua aplicação nos projetos que ele apresenta. No caso específico das proporções e da compartimentação das residências isso é percebido em diversos momentos, já que Palladio parte de premissas originais, mas na execução de seus projetos acaba se aproximando daquelas albertianas.

Em cada um dos parâmetros analisados essa situação se repete, aumentando a aproximação entre as vilas dos dois autores, que no próprio texto escrito já são inúmeras. 
De fato, a genialidade de Palladio não se manifesta somente por sua originalidade absoluta, mas pela forma original com que ele aplica formas e conceitos que já existiam anteriormente de modo completamente novo, autêntico e variado. 



\section{CONSIDERAÇOES FINAIS}

Durante a realização dessa pesquisa ficou evidente que, mesmo delimitando a área de estudo em torno de um tema específico, como as vilas, são muitas as possibilidades que se abrem ao colocar lado a lado as propostas de Alberti e Palladio. Os dois tratados apresentam várias leituras e interpretações possíveis, cada um com seu tipo de texto: a palavra, o desenho e, eventualmente, o próprio edifício.

As principais diferenças percebidas entre as propostas dos dois autores estão associadas às diferenças existentes entre os dois tratados. Enquanto Alberti trabalha de forma analítica, fazendo longas dissertações a respeito de cada tema, buscando referências antigas com as quais dialogar, Palladio sistematiza suas propostas de forma sintética, reduzindo o texto ao mínimo necessário e deixando para os desenhos o protagonismo no discurso sobre as vilas.

Dos dez livros de seu tratado, Alberti fala diretamente sobre o projeto de edifícios privados - onde estão incluídas as vilas - em pelo menos quatro: I, II, V e IX. Já Palladio, faz sua abordagem de forma bastante sistemática e organizada, com capítulos e livros que tratam de temas bem definidos.

Como se tentou demonstrar no capítulo 2, essa diferença tem estreita relação com o ambiente em que os tratados - assim como as vilas - foram produzidos.

Alberti escrevia, em latim, para grandes personagens de formação Humanista, como Lorenzo de Médici. As referências antigas demonstravam sua erudição aos comitentes, assim como emprestavam dignidade e intelectualidade à arquitetura. Palladio escrevia para um público mais geral, ainda que muitos de seus leitores - e comitentes - também tivessem formação Humanista, ele próprio se aproximava mais do moderno especialista que do ideal de renascentista de homem universal. Seu tratado poderia ser uma espécie de portfólio, demonstrando sua capacidade inventiva e múltipla de sintetizar bela maneira de se construir? Possivelmente.

Enquanto Alberti, ao escrever seu tratado - e provavelmente em decorrência disso, passou a desempenhar também papel de arquiteto, Palladio escreveu seu tratado a partir de sua atuação na arquitetura, o que evidencia os caminhos opostos que os dois percorreram.

Um exemplo emblemático das variações temporais e regionais das vilas dos dois autores é a espécie de veto que 
Alberti faz ao uso de formas medievais, como merlaturas, sob o risco de serem associadas à tirania dos senhores feudais. Em uma crítica muito provavelmente dirigida a Cosimo de' Medici, ele reprova as, assim chamadas, vilas-castelo. Palladio, por outro lado, em vários de seus projetos, utiliza as torres colombaras como um verdadeiro símbolo de 'signoria'.

A concepção de vila de cada um dos dois autores foi marcada por diferenças regionais, além da época e do contexto histórico. A definição de vila, para Alberti, variou ao longo do tempo: No início, ela era associada a uma residência secundária para o morador da cidade abastado; depois ela passou a ser entendida como propriedade rural, independente de ter ou não um edifício residencial; por fim, a definição madura, publicada no tratado fundia as duas anteriores em uma propriedade rural, com finalidade produtiva, mas também dedicada ao repouso e ao ócio. A definição de Palladio aproxima-se daquela final de Alberti, mas talvez não tanto pela afinidade entre os autores quanto por ser a situação predominante no vêneto.

De fato, a partir dessa definição semelhante, surgem algumas recomendações também semelhantes dos dois autores. Visando a produtividade da vila e a salubridade do edifício e de seus habitantes, ambos fazem orientações quanto à escolha do local onde situar a propriedade e também a casa, em seu interior. As semelhanças são grandes, mas são percebidas variações decorrentes de particularidades regionais, como, por exemplo: a facilidade de acesso à propriedade para a vila albertiana, na toscana, significa estar próxima a uma estrada que leve com facilidade e comodidade à residência citadina do proprietário; já para a vila veneta paladiana, significa proximidade a algum rio navegável, por onde escoar facilmente a produção agrícola. Mesmo com essas variações, percebe-se que é comum a preocupação com a localização, o acesso e, principalmente, a comunicação entre vila e cidade, quase como se estendessem ao espaço rural uma espécie de planejamento urbanístico.

Quando começam a estabelecer diretrizes para as propriedades essa preocupação urbanística também aparece nos discursos dos dois autores. Tratando a casa como uma pequena cidade, são discutidas relações entre as partes e o todo com argumentações bastante semelhantes, levando a crer que Palladio não só leu o tratado de Alberti, como o tomou como base para o estabelecimento de suas diretrizes compositivas. São identificadas relações dimensionais, antropomórficas, 
proporcionais e até mesmo conceituais, como a variedade recomendada por Alberti e levada a cabo por Palladio em seu conjunto de projetos.

Quanto à setorização das vilas e, principalmente, das residências também há semelhanças, ainda que Palladio opte por fazer referência a Vitruvio. Como foi descrito há pouco, o tratado de Alberti possui uma organização não muito clara. Apesar de ser dividido em dez livros, supostamente equivalentes a dez temas, Alberti tece sua argumentação quase como uma teia, onde os temas se entrelaçam e se interpenetram, tornando difícil puxar somente um fio na tentativa de tornar esse discurso linear. Amo ${ }^{1}$ falou do tratado como uma sequência de espirais concêntricas, mas essa descrição parece ainda insuficiente para indicar a complexidade do discurso, já que a espiral sugere se tem um fio condutor ou, ao menos, um eixo em torno do qual os discursos são desenvolvidos.

A opção de referir-se a Vitruvio, que permite mais facilmente o estabelecimento desse paralelo, parece ser apenas formal. Talvez, além de o próprio texto ganhar prestígio com o estabelecimento dessa relação, ele também possa se isentar da responsabilidade de estabelecer uma hierarquia entre seus próprios comitentes. Tendo em vista que o tratado também foi escrito para eles, é compreensível que Palladio tivesse o cuidado de não desagradá-los.

Para o desenvolvimento dos projetos, por outro lado, ele poderia lançar mão de algumas das muitas recomendações de Alberti, já que, ao apresentá-las, ele teria sido o primeiro a deixar de lado a hierarquia rígida e estabelecer inúmeras diretrizes que, sempre que possível, devem ser aplicadas por todos.

É importante destacar que, para Alberti, o decoro tinha um papel fundamental, ainda que ele admitisse maior flexibilização das normas em residências localizadas fora da cidade, como as vilas. De uma forma geral, seu texto versa sobre a construção dos edifícios e da cidade paralelamente e, por isso, a observação do decoro e das formas que são reservadas a cada tipo de uso é sempre referenciada. Palladio, por sua vez - talvez por estar projetando em propriedades fora dos muros citadinos e, portanto, afastadas desse conjunto homogêneo e restritivo - ignora completamente as recomendações albertianas quanto ao decoro. Isso fica evidente ao se observar

1 Amo (1988). 
que, enquanto Alberti reserva os frontões aos templos, Palladio não hesita em aplicá-los em suas fachadas residenciais.

$\mathrm{Na}$ setorização das casas de vila se percebe um dos principais pontos em que o discurso dos dois autores se mostra claramente divergente. Quando Alberti organiza os cômodos em três zonas - receber, repousar e servir - ele parece antecipar a tripartição burguesa. Já Palladio, cerca de cem anos mais tarde, propõe uma divisão bipartida, com cômodos a serem exibidos e outros a serem escondidos. Ao retirar do piano nobile os cômodos a serem escondidos - quase sempre no pavimento semienterrado e no celeiro - Palladio coloca todo o pavimento principal da residência como um grande espaço para receber. Ainda que essa função social recaísse principalmente no eixo central, que muitas vezes atravessa o edifício (loggiavestíbulo-salão-vestíbulo-loggia), os cômodos laterais também poderiam desempenhá-la.

Quanto à compartimentação dos edifícios, novamente se verifica grande convergência entre as proposições dos autores. Ao tratar da compartimentação dos edifícios como sendo sua principal ornamentação, Alberti parece muitas vezes estar se referindo às vilas paladianas. Com uso parcimonioso dos elementos e ornamentos antigos, Palladio desenvolve um repertório compositivo basicamente formado por relações formais e proporções. Para Palladio, a Antiguidade não é um conjunto de formas a serem copiadas, mas um repertório vivo e declinável, com o qual ele trabalha criando diversas e ricas variações.

- desenvolvimento dessa pesquisa de doutorado foi motivado por algumas semelhanças entre os discursos dos dois autores que tinham sido detectadas durante algumas leituras preliminares. Não se esperava, contudo, perceber uma afinidade tão grande entre os modelos de vila apresentados pelos dois autores, como ocorreu nos aspectos analisados.

No decorrer da pesquisa, foi percebido que há ainda outros pontos a serem discutidos em relação a projetos de vilas e aos parâmetros utilizados. Se cada um dos tratados sozinho abre um vasto campo de estudos, quando são comparados eles permitem ainda mais análises e discussões.

Há muitos outros aspectos e muitos outros pontos que podem ser explorados, como, por exemplo, a relação dos dois tratados com a representação gráfica, que aqui foi discutida somente no que diz respeito às vilas. Enquanto Alberti utiliza o texto para falar, detalhadamente, sobre o desenho, Palladio 
lança mão do desenho para transmitir informações, como se eles fossem texto.

Espera-se que essa tese possa motivar novos estudos tanto sobre as vilas quanto sobre os tratados de Alberti e Palladio, pois, apesar de separados por cerca de quinhentos anos dos dias de hoje, ainda há muito que se discutir e que se aprender com seu estudo. 


\section{REFERÊNCIAS}

ACKERMAN, J.S. La villa: Forma e ideologia. Turim: Einaudi, 1992. P.398.

ACKERMAN, J.S. Palladio. Tradução para o italiano de Giuseppe Scattone. Turim: Einaudi, 1996.

ACKERMAN, J.S. Architettura e Disegno: La rappresentazione da Vitruvio a Gehry. Milão: Electa, 2003. 276p.

ACKERMAN, J.S. La villa: forma e ideologia. In: BELTRAMINI, G.; BURNS, H. (Org). Andrea Palladio e la villa veneta da Petrarca a Carlo Scarpa. 10. Ed. Veneza: Marsilio Editori, 2009.

ALBERTI, L.B. L'Architettvra di Leonbatista Alberti: Tradotta in Lingva Fiorentina da Cosimo Bartoli, Geltilhuomo \& Academico Fiorentino. Con la aggiunta de' disegni. Veneza: Francesco Franceschi, 1565 .

ALBERTI, L.B. I libri della famiglia. Org. Ruggiero Romano, Alberto Tenenti e Francesco Furlan. Turim: Einaudi, 1994. 362p.

- L'Arte di Costruire. Org. Valeria Giontella. Turim: Bollati Boringhieri Editore, 2010.

- Da Arte Edificatória. Organização e revisão disciplinar Mário Júlio Teixeira Krüger. Tradução do latim Arnaldo Monteiro do Espírito Santo. Lisboa: Fundação Calouste Gulbenkian, 2011 (a). $770 \mathrm{p}$.

. Villa. Milão: Simplicissimus Book Farm, 2011(b). 8p.

ALMEIDA, F. ̇̀ luz da cadência: a música na arquitetura. UFPE: Recife: 2005 .

AMO, J. A.. La Teoria de la Arquitectura em los Tratados: Alberti. Madrid: Tebar Flores, 1988. 158p.

ARGAN, G. C. Clássico Anticlássico: O Renascimento de Brunelleschi a Bruegel. Tradução Lorenzo Mammì. São Paulo: Companhia das Letras, 1999.

ARIÈS, P. Por uma história da vida privada. In: História da vida privada, 3: Da Renascença ao Século das Luzes. Org: Roger 
Chartier. Tradução de Hildegard Feist. São Paulo: Companhia das Letras, 2009.

BARBOSA, R. F. Explorando as vilas de Palladio: Uma leitura contemporânea sobre composição arquitetônica. 2005. 302p. Dissertação (Mestrado em Arquitetura) - Faculdade de Arquitetura, Universidade Federal do Rio Grande do Sul, Porto Alegre, 2005.

BAtTilotTI, D. Andrea Palladio. Milão: Mondadori, 2011. 80p.

BELLIN, P. (Org.). Lezioni in Villa: La civiltá di villa tra otium et negotium. Treviso: Liceo Scientifico statale, 2009. $162 \mathrm{p}$.

BELTRAMINI, G.; BURNS, H. (Org.). Andrea Palladio e la villa veneta da Petrarca a Carlo Scarpa. 10 ed. Veneza: Marsilio Editori, 2009.

BELTRAMINI, G.; BURNS, H. (Org.). Palladio workshop: $55^{\circ}$ Corso sull'architettura palladiana. Catálogo das obras estudadas e visitadas. Vicenza: Cisapalladio, 2 a 7 de setembro de 2013. $115 \mathrm{p}$.

BENEVOLO, L. Introduzione all'architettura. Bari: Laterza, 1972.

BENSIMON, N.B. La relazione didattica nei Libri della famiglia di Leon Battista Alberti. Chroniques Italiennes. Université de la Sorbonne Nouvelle, Paris - França, $\mathrm{n}^{\circ}$ 36, p.31-54, 1993. Disponível em: <http://chroniquesitaliennes.univparis3.fr/PDF/36/Bianchi.pdf>.

Acesso em: 02/2014.

BRANDÃO, C.A.L. A formação do homem moderno através da arquitetura. 2 ed. Belo Horizonte: Ed. UFMG, 1999. 240 p.

BRANDÃO, C.A.L. Quid Tum?: O combate da arte em Leon Battista Alberti. Belo Horizonte: Ed. UFMG, 2000. 375 p.

BRUSCHI, Arnaldo. Introduzione. In: Storia dell'architettura italiana: il primo cinquecento. A cura di Arnaldo Bruschi. Milão: Electa, 2002. 9-33p.

BUENO, B.P.S. Desenho e Desígnio: O Brasil dos Engenheiros Militares (1500-1822). São Paulo: Fapesp, 2011. 353p. 
BURGUER, F. Le ville di Andrea Palladio: Contributo alla storia dell'evoluzione dell'architettura rinascimentale. Org: Elena Filippi e Lionello Puppi. Tradução de Elena Filippi. Turim: 2004, Umberto Allemandi \& C. p.217.

BURNS, H. La villa italiana del Rinascimento. Tradução de Ilaria Abbondandolo. Costabissara (Vicenza): Angelo Colla Editore, 2012. p.159.

CHOAY, F. A regra e o modelo: sobre a teoria da arquitetura e urbanismo. Tradução de Geraldo Gerson de Souza. 2. ed. São Paulo: Perspectiva, 2010. 334p.

CORBOZ, A. Il paradosso della villa storica. In: La villa in Italia: Quattrocento e Cinquecento. Milão: Electa, 1995. p.9.

DE FUSCO, R. Il Codice dell'Architettura: Antologia di Trattatisti. Napoli: Liguori, 2003. 600p.

DE LA RONCIÈRE, C. A vida privada dos toscanos no limiar da Renascença. In: História da vida privada, 2: da Europa Feudal à Renascença. Org: Georges Duby. Tradução de Maria Lúcia Machado. São Paulo: Companhia das Letras, 2009.

DI TEOdORO, F. P. Vitruvio, Piero della Francesca, Rafaello: note sulla teoria del disegno di architettura nel Rinascimento. Annali di architettura - Rivista del Centro Internazionale di Studi di Architettura Andrea Palladio di Vicenza, Vicenza Itália. N.14, p.35-54, 2002 .

EVERS, B. (Org.). Teoria da arquitetura: Do Renascimento até aos nossos dias 117 tratados apresentados em 89 estudos. Colônia: Taschen, 2003.

FROMMEL, C.L. La nuova villa a Firenze e a Roma. In: Andrea Palladio e la villa veneta da Petrarca a Carlo Scarpa. Org: Guido Beltramini e Howard Burns. 10 ed. Veneza: Marsilio Editori, 2009.

FROMMEL, C. L. Architettura del Rinascimento italiano. Milão: Skira, 2009. 360p.

FURNARI, M. Atlante del Rinascimento: il disegno dell'architettura da Brunelleschi a Palladio. Nápoles: Electa, 1993. 260p. 
GRAFTON, A. Leon Battista Alberti: Un genio universale. Tradução para o italiano de Luca Falaschi. Bari: Laterza, 2003. $535 \mathrm{p}$.

HAUSER, A. História Social da Arte e da Literatura. Tradução de Álvaro Cabral. 1 ed. São Paulo: Martins Fontes, 2000. pp. 248376.

HEYDENREICH, L. H. Arquitetura na Itália: 1400 - 1500. Tradução de Maria Thereza Rezende Costa. São Paulo: Cosac e Naify Edições, 1998. 196p.

KOCH, W. Dicionário dos Estilos Arquitetônicos. Tradução de Neide Luzia de Rezende. 4.ed. São Paulo: Martins Fontes, 2009. 231 p.

KRÜGER, M. L. Introdução e Notas. In: Da Arte Edificatória. Lisboa: Fundação Calouste Gulbenkian, 2011(a). 770p.

LANCHA, J. J.. Os dois textos de Palladio. Pós - Revista do Programa de Pós Graduação em Arquitetura e Urbanismo da FAU/USP, São Paulo - Brasil, v. 17, p.076-087, 2005.

- Os dois textos de Palladio. In: MIZOGUCHI, I; MACHAdo, N.H.N. (Org) Palladio e o Neoclassicismo. Porto Alegre: EDIPUCRS, 2006, p.75-91.

- O tratado de Andrea Palladio. In: PALLAdio, A. I Quattro Libri dell'architettura. São Paulo: Hucitec, 2009. p. IX-XXXVII.

- O desenho e os cômodos na villa Foscari de Palladio. In: ENCONTRO DE HISTORIA DA ARTE, 6, 2010, CAMPINAS. Atas do VI Encontro de História da Arte: História da Arte e suas fronteiras. Campinas: Unicamp, 2010, p. 220-230. Disponível em: <http://www.unicamp.br/chaa/eha/atas/2010/joubert_jose_lancha.p df>. Acesso em: 05/2013.

LOEWEN, A.B. Lux Pulchritudinis: sobre beleza e ornamento em Leon Battista Alberti. Tese (Doutorado em Arquitetura e Urbanismo). São Paulo: FAUUSP, 2007. 216p.

LOTZ, W. L'architettura del Rinascimento. Milano: Electa, 1997. 233p.

LUCCAS, L. H. H. Distribuição na arquitetura do renascimento italiano. Sobre arranjos, compartimentação e circulação 
interior na casa renascentista. Arquitextos, São Paulo, ano 11, n. 129.03, Vitruvius, fev. 2011. Disponível em: <http://www.vitruvius.com.br/revistas/read/arquitextos/11.129/3 748>. Acesso em: 05/2014.

MAGNAGANO, L; MARINI, P. Introdução e Notas. In: I Quattro Libri dell'Architettura. Milão: Il Polifilo, 1980.

MALARD, M.L. As Aparências em arquitetura. Belo Horizonte: Editora UFMG, 2006. 236 p.

MARTINEZ, A. C. Ensaio sobre o projeto. Brasília: Editora UnB, 2000 .

MURRAY, P. L'architettura del Rinascimento italiano. Tradução para o italiano de Gigliola Margiotta Broglio Fragnito. Bari: Laterza, 2007. 301p.

OLIVEIRA, M.M. Desenho de Arquitetura Pré-Renascentista. Salvador: EDUFBA, 2002. 273 p.

PAIVA, V. A identidade como obra coletiva em O Cortesão, de Baldassare Castiglione. Tempo Social, Revista de Sociologia da USP, v. 21, n. 1, 2009. p.91-111.

PALLADIO, A. I Quattro Libri dell'Architettura di Andrea Palladio. Ne' quali, dopo un breve trattato de' cinque ordini, e di quelli avvertimenti, che sono piu neccessarii nel fabricare; si tratta delle case private, delle vie, de i ponti, delle piazze, de $i$ Xisti, et de' Tempii con privilegi. Veneza: Dominico de' Franceschi, 1570.

- Los Quatro Libros de Arquitectura. Tradução e notas de Don Joseph Francisco Ortiz y Sanz. Madrid: Imprensa Real, 1797. $184 \mathrm{p}$.

- I Quattro Libri dell'Architettura. Introdução e notas

de Liscio Magagnato e Paola Marini. Milão: Il Polifilo, 1980.

- Os Quatro Livros da Arquitetura: nos quais após um breve tratado das cinco ordens e dos conselhos mais necessários ao construir, se trata das casas particulares, das ruas, das pontes, dos xistos e dos templos com privilégios. Coordenação Joubert José Lancha; tradução Maria Augusta de Bastos Mattos, Cesar Augusto de Oliveira Casella. São Paulo: Hucitec, 2009. $340 \mathrm{p}$. 
PEREIRA, C.C. Architectural Pratice and the Planning of Minor Palaces in Renaissance Italy: 1510-1570. 1998. 284p. Tese (Doutorado em Arquitetura). Massachussets Institute of Technology - MIT, Cambridge, 1998. Disponível em: < >. Acesso em: $11 / 01 / 2014$.

PUPPI, L. (Org.) Andrea Palladio: Scritti sull'Achitettura 1554-1579). Vicenza: Neri Pozza Editore, 1988.

PUPPI, L. Delle case di villa. Turim: Umberto Allemandi \& C., 2005. p.157.

PUPPI, L.; BATTILOTTI, D. Andrea Palladio. Milão: Mondadori Electa Spa, 2006. 569p.

RABELO, F, A. Arquitetura e Música: Interseções Polifônicas. 2007. Dissertação (Mestrado em Arquitetura) - Faculdade de Arquitetura, Universidade Federal do Rio Grande do Sul, Porto Alegre, 2007 .

RAMOS, F.G.V. Os tratados do século XX: edições especiais. Arq.Urb, São Paulo, n.5, p.55-74, 2011. Disponível em: < http://www.usjt.br/arq.urb/numero_05/

arqurb5_07_artigo_fernando_vazquez.pdf $>$. Acesso em: 06/08/2013.

RYBCKZYNSKI, W. The Perfect House. A Journey with the Renaissance Master Andrea Palladio. Nova Iorque: Scribner, 2002. 283p.

SEVCENKO, N. O Renascimento. São Paulo: Atual, 1988.

SOUZA, M.L.Z. Carta de Rafael Sanzio - Castiglione ao Papa Leão $X$ e sua importância para o Estudo da Arquitetura e do Urbanismo do período do Renascimento. 2006. 285p. Dissertação (Mestrado em Arquitetura e Urbanismo) - Faculdade de Arquitetura e Urbanismo, Universidade de São Paulo, São Paulo, 2006.

TAVARES, D. Leon Battista Alberti: teoria da arquitectura. Porto: Dafne Editora, 2003. 139p.

TAVARES, D. Andrea Palladio: a grande Roma. Porto: Dafne Editora, 2008. 137p.

THOENES, C. Sostegno e adornamento. Saggi sull'architettura del Rinascimento: disegni, ordini, magnificenza. Introdução de James Ackerman. Milão: Electa, 1998. 263p. 
THOEnES, C. Leon Battista Alberti. In: EVERS, B. (Org.). Teoria da arquitetura: Do Renascimento até aos nossos dias 117 tratados apresentados em 89 estudos. Colônia: Taschen, 2003.

TRAMONTANO, M. Paris-São Paulo-Tokyo: novos modos de vida, novos espaços de morar. Tese de doutorado. São Paulo: FAUUSP, 1998.

VASARI, G. Le vite de' più eccellenti architetti, pittori, et scultori italiani, da Cimabue insino $a^{\prime}$ tempi nostri. Nell'edizione per $i$ tipi di Lorenzo Torrentino, Firenze 1550, a cura di Luciano Bellosi e Aldo Rossi. Turim: Einaudi, 1986.

VISENTINI, M. A. La villa in Italia. Quattrocento e Cinquecento. Milão: Electa, 1995. 364p.

WARNKE, M. O Artista da Corte: Os Antecedentes dos Artistas Modernos. Tradução Maria Clara Cescato. São Paulo: Edusp, 2001. $394 \mathrm{p}$.

WITTKOWER, Principi architettonici nell'eta dell'umanesimo. Tradução de Renato Pedio. Torino : Einaudi, 1992. 165p.

WUNDRAM, M.; PAPE, T. Andrea Palladio: 1508 - 1580 Arquitecto entre el Renacimiento y el Barroco. Tradução do alemão: Carlos Caramés. Köln: Taschen, 2008.

ZECCHINo, F. La Villa di Poggioreale, residenza degli Aragonesi a Napoli. Delpinoa, Periodico dell'orto Botanico di Napoli e del Dipartimento di Biologia Università degli studi di Napoli Federico II. N. 44, 2002. P-3-16.

ZEVI, B. Saber ver a arquitetura. Tradução de Maria Isabel Gaspar. 6a. Edição. São Paulo: Martins Fontes, 2009.

ZORZI, Giangiorgio. Le ville e i teatri di Andrea Palladio. Veneza: Neri Pozza, 1969.

ZUFFI, S. Postfazione. In: Le ville venete. Milano: Abscondita Srl, 2003.p.77-84. 248p. 


\section{APÊNDICE A}

Esse texto apresentado a seguir é a tradução de Villa, de Leon Battista Alberti, ainda inédita em português, elaborada pela autora para o desenvolvimento desse trabalho.

A tradução foi elaborada a partir do texto original, publicado em 2011 em Milão, pela Editora Simplicissimus Book Farm.

\section{Vila}

Comprarás a vila para alimentar a tua família, não para dar deleite a outros. Pensa e repensa antes que decidas que aquilo te agrada, porque darás o que agrada a todos, isto é, o dinheiro. E se talvez hoje te agrade, repensa se depois de amanhã poderá te agradar menos. É inútil ter pressa. E talvez prejudique a pressa, quando nada pode piorar por esperar. Compra de quem amava sua posse, não de quem por mais vezes tentou se desfazer dela. Não é caro aquilo que se compra como aos outros pode parecer, faz boa compra quem compra de um bom proprietário. Daquilo que tu compraste mal uma vez, muitas vezes te arrependerás. Sempre poderás gastar teu dinheiro melhor do que poderás vender o terreno. Um campo cultivado em lugar ruim será pior do que um solo não preparado em boa localidade. Será mal localizado aquele campo ao qual o rio esteja de frente. Ainda pior será o mau vizinho, atrás ou do lado que for. Coisa divina, dizem ser o bom vizinho. Assim, pelo contrário, coisa péssima é o mau vizinho. Nem campo fértil em lugar insalubre, nem campo estéril em lugar muito são me agradam. Não é são onde não sejam saudáveis todo ano. A terra tu podes corrigir, de aquosa torná-la seca, ou se é pobre em nutrientes podes adubá-la, mas nunca modificarás o céu. Campo estéril não será somente aquele que nada produz, mas também aquele que não dá resultados compatíveis com teus esforços. Fértil será aquele que produza abundantemente sem necessidade de outros adubos. A casa faz menos falta à propriedade que as terras à casa. A vila será ótima quando demandar esforço e não despesa. E seja a vila não como uma casa afastada da praça, de modo que precises comprar do mercado tudo para abastecê-la, mas seja tal que, exceto pelo sal, possivelmente tenhas excedente de cada coisa que possa ser vendida no mercado. Como se diz dos filhos, também da vila: uma é pouco, duas é muito, três é demais.

Comprada a vila, primeiramente cuide para que teus vizinhos te queiram tanto bem quanto te querem os teus 
parentes. Os amigos estarão prontos para te ajudar muito antes dos parentes. E onde tens um vizinho amigo, podes dizer que lá também estás. Amar-te-á aquele que receber de ti o que, se dele recebesses, amarias. A quem te ama, evita ser maçante ou pesado nos atos e nas palavras.

Abastece a casa do que precisas e do que provavelmente precisarás. Não compres nenhuma das coisas que podes obter das tuas terras. Quem tem somente um arado, na verdade não tem nenhum; se tiver dois, danificando-se um, não perderá tempo e poderá utilizar o outro. Será bem provido quem terá para emprestar aos outros. E, quem deve pedir aos outros o que lhe serve, será muito mal servido. A necessidade é algo difícil, e é dificil suplicar; as duas coisas juntas são intoleráveis e ainda mais prejudiciais que difíceis. E se te parece fácil suplicar, muito mais fácil será para mim negar-te aquilo que pedes. E pedindo frequentemente o que tu queres, sempre causarás incômodo.

Compraz a Esíodo, elegantíssimo poeta grego, aquele trabalhador que partirá o pão em quatro partes e de cada uma fará oito mordidas; e que ele dome o campo, e não que o campo o extenue. Nunca darás ócio aos servos e aos jumentos. Dizem que a fome e a necessidade moram próximas do ócio. A esses darás ordens úteis, providenciarás o que for necessário, e os encarregarás daquilo a que estão aptos e habituados. Não aceitarás que façam durante o dia o que podem fazer à noite, nem em dias de trabalho o que pode ser feito em dias festivos. Determinarás que eles sejam mais assíduos no campo do que em qualquer outro lugar, e que o que menos façam seja não fazer nada. E tu, quando o dia seja sereno, consideres turbulenta e desagradável a sombra da casa. Para o que podes fazer com o asno, não utilizes o servo. Seja tua a tarefa de comandar; aos servos caberá obedecer-te e fazer o que mandaste. Prepara-te para comandar somente uma vez para mais atividades e por mais dias. Abomina tu o comandar mais vezes ou a mais pessoas para uma mesma coisa. Aquele que deve obedecer muito te satisfaz, se faz quanto e quando tu mandaste e ordenaste. É ótimo aquele que por conta própria faz coisas úteis e louváveis. Aquele que faz quando o ordenaste, em comparação com o ótimo, é bom. Aquele que não faz nem por conta própria e nem quando alguém o lembra, dentre todos é o pior. Todos os bons amigos fora de casa não remediarão os danos que faz um mau servo em casa. Nada te será mais prejudicial que um mau servo que te deixe a casa desordenada. Quem não tem nada a perder e perde, perde o que deveria ter. Nenhum animal teme a nuca do homem, mas, por mais 
selvagem e feroz que seja, teme seu rosto. Dizem que somente o feno grego gosta de ser abandonado e que qualquer outra coisa sofre com esse abandono.

Organizados a casa, os servos e as coisas, atribuas as tarefas. Sobre isso, dizem que a coisa mais importante é preocupar-se com a terra, usar o ferro e o fogo ${ }^{1}$ com frequência: a segunda é adubar com esterco: a terceira é semear a terra com aquilo de que se espera o fruto. Diz Hesíodo: "are nu, semeie nu e ceife nu" ${ }^{2}$. Os antigos afirmam ser menos útil semear que arar; e dizem que não há nada mais a fazer além de cultivar bem - campo, e que isso é suficiente onde ele é bem administrado. À vinha não darás nada nem tirarás nada. O campo e o prado não devem ser nem encharcados e nem secos. E daquilo que colheres, deixa uma parte à terra. Aduba somente nas fases extremas da lua, nem antes nem depois. Os caules das favas são venenosos para todas as culturas, qualquer outra coisa que tenha nascido e crescido será bom adubo. É melhor que a adubação seja pouca do que seja excessiva; mas mesmo que seja excessiva, não prejudicará demais. Qualquer coisa que nasceu e cresceu está apta a virar adubo. E dessas são melhores aquelas que demoram mais a apodrecer e que estejam mais secas. E, dessas, aquelas que viram mais sol e menos vento, mais frio e menos água. Mas de todos os adubos o melhor será que tu cuspas nos quatro cantos do campo no primeiro dia de cada mês ${ }^{3}$. Mais louvam quem semeou três dias antes, do que quem semeou dois dias depois. A semente precoce raras vezes engana, mas aquela tardia engana sempre. Se lançares as sementes fora da estação propícia não semeias, mas as desperdiças. Não semearás na lua nova. Outros dizem que o que se semeia na lua nova não produz vermes. Planta as árvores pequenas e poda as grandes. Faz alporquia na ameixeira, na cerejeira e na macieira. Não firas nem amarres a oliveira. Não plantes em lugar quente o que nasceu no frio. As temperaturas extremas não desagradam somente à oliveira, todas as raízes que se alimentam da terra preferem o clima temperado. Deixa ao sol a uva e todas as tuas expectativas. Afasta da sombra o carvalho, o pinheiro, o abeto e a picea. As árvores de

\footnotetext{
${ }^{1}$ Aqui o autor se refere ao preparo da terra: o fogo faz parte da prática agrícola de se queimar os restos de cultivos anteriores para limpar e adubar o terreno; o ferro é uma referência ao uso do arado.

2 Para Hesíodo o trabalho deveria ser feito nu, para purificação do corpo e do espírito, e também provavelmente como um ritual para fertilidade dos campos.
} 
poucas folhas, aquelas cujas folhas tremem ${ }^{4}$ e as caducifólias não são amigas, mas não são inimigas. Inimigos dos vinhedos são - louro e, também, a couve; o rabanete desdenha tanto os pâmpanos ${ }^{5}$ quanto os caules da videira. Mas nada prejudica mais toda a vila quanto não observar a cada dia onde nasce o sol e onde ele se põe. Aquilo que podes fazer hoje, não deixes para amanhã. Com aquilo que não podes fazer, não te preocupes, e quanto ao que deverias ter feito, não podes mais fazer nada. A quem perde tempo aumentam-se as tarefas, a protelação torna o objetivo contumaz e fugidio. A manhã leva à metade do caminho, e a ela corresponde um terço de toda tarefa bem feita.

Com o campo bem cultivado vêm as colheitas. Serra, ceifa e colhe quando já estão crescidas e antes que comecem a decrescer. Não colhas a uva nem quando ela estiver quente nem úmida de orvalho. Dizem que a uva colhida na lua nova dura mais por não ser mordida por pequenos animais. Pisa as uvas tendo o mosto e a lua no lagar. Areja e armazena os grãos na lua cheia. Aquilo que a terra te deu, devolvas-lhe. Outros dizem que a terra é o lobo dos deuses. Mas se a terra não bebe, ela também não se alimenta. Todas as sementes precisam de água, cinzas e cal. Quando cortas, arrancas ou podas, observa que seja na lua nova ou minguante. A colheita será ótima quando não for pior do que a de teus vizinhos, e será grande aquela que demandar pouco investimento. Melhor colheita será aquela que te abastecerá ao longo dos meses do que aquela que encherá de uma vez todos teus celeiros. Guarda as coisas onde as reencontrarás; utiliza-as o quanto for necessário; poupa-as o quanto queiras; venda-as quando puderes. Bebe quando o barril estiver cheio, e bebe quando ele estiver meio vazio. Que o fogo nunca se apague em casa, e nunca arda inutilmente. De cada fruto da terra dá uma parte a Deus e agradeças. Nenhuma doação será maior que aquela livre de toda injustiça. Nada mais justo para se enriquecer do que a agricultura. E as riquezas que se acumulam sem fraude são um bem divino. O abundante é o que menos cresce. Junta obra à obra e diminuirás necessidades: junta atividade à atividade e aumentarás felicidade. Estejas atento aos teus interesses. Elogia os alheios. Se pensares, pensa no que te diz respeito. Se fizeres, faz para ti e para outros. Se falares, não fales de ti nem dos outros. Mas se acontecer, fala da prosperidade alheia. Ou seja, dos rebanhos bovino e ovino, do aviário, das abelhas, da horta e afins.

\footnotetext{
4 No sentido utilizado no texto, árvores cujas folhas tremem podem ser entendidas como as latifoliadas, ou com folhas largas e grandes.

5 Haste de videira coberta de folhas.
} 


\section{APÊNDICE B}

Os materiais apresentados a seguir foram desenvolvidos pela autora para os estudos realizados no decorrer da pesquisa e embasaram as análises aqui apresentadas. 
VILLA CAPRA

ÁREAS - Setores
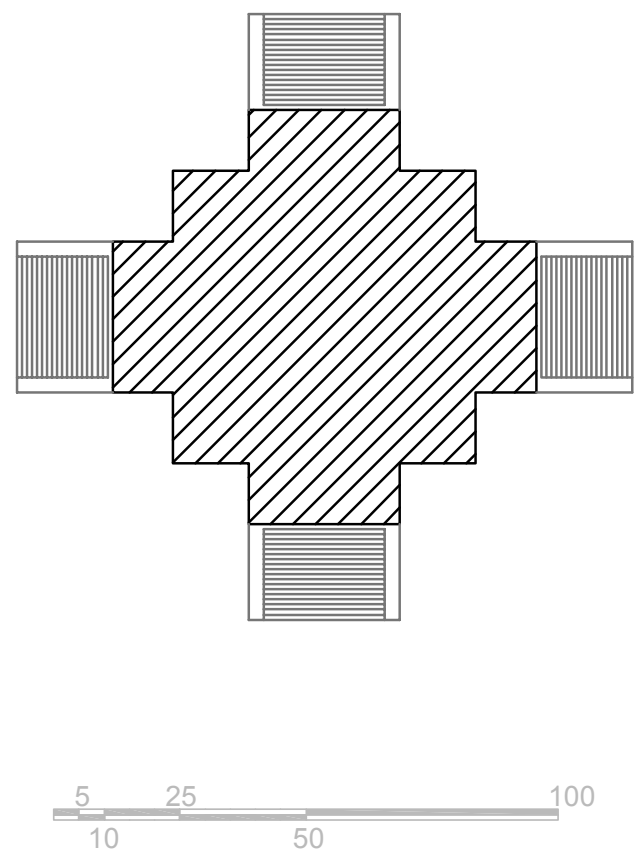

YlfIIIty casa $627,05 \mathrm{~m}^{2}$ 


\section{VILLA CAPRA}

Proporções dos cômodos

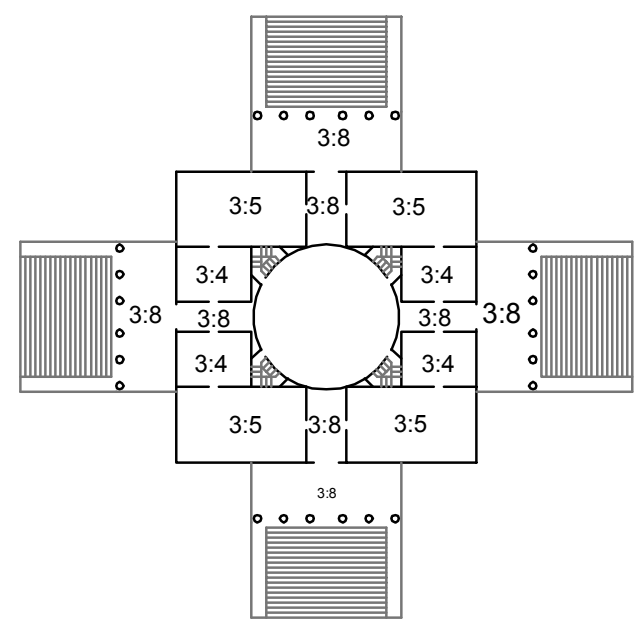

\section{APARTAMENTOS - Tamanhos dos cômodos}
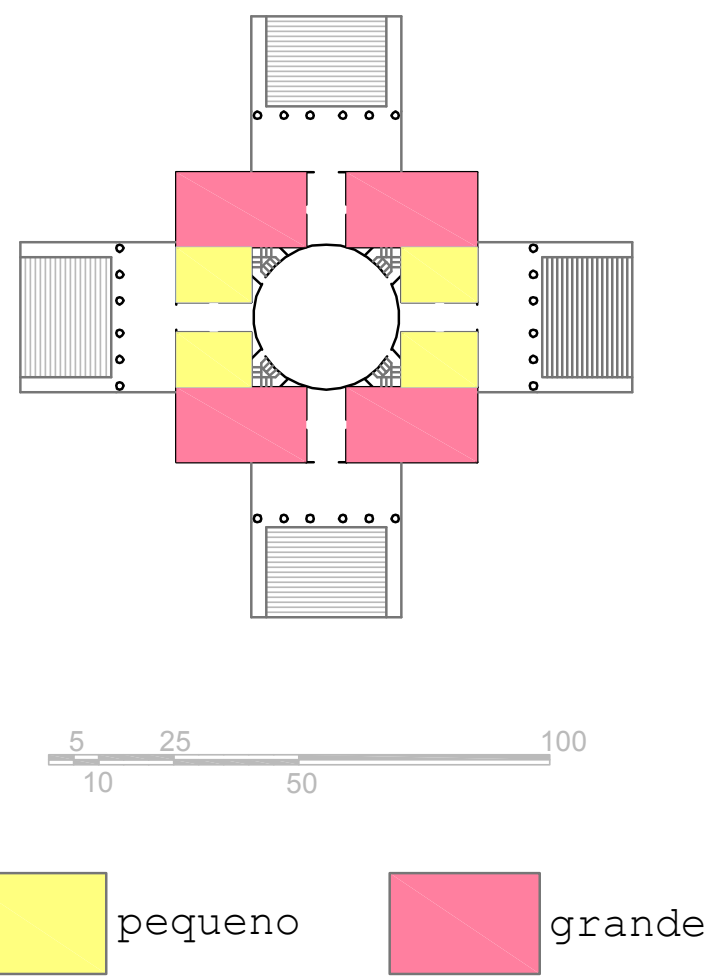


\section{ÁREAS - Setores}
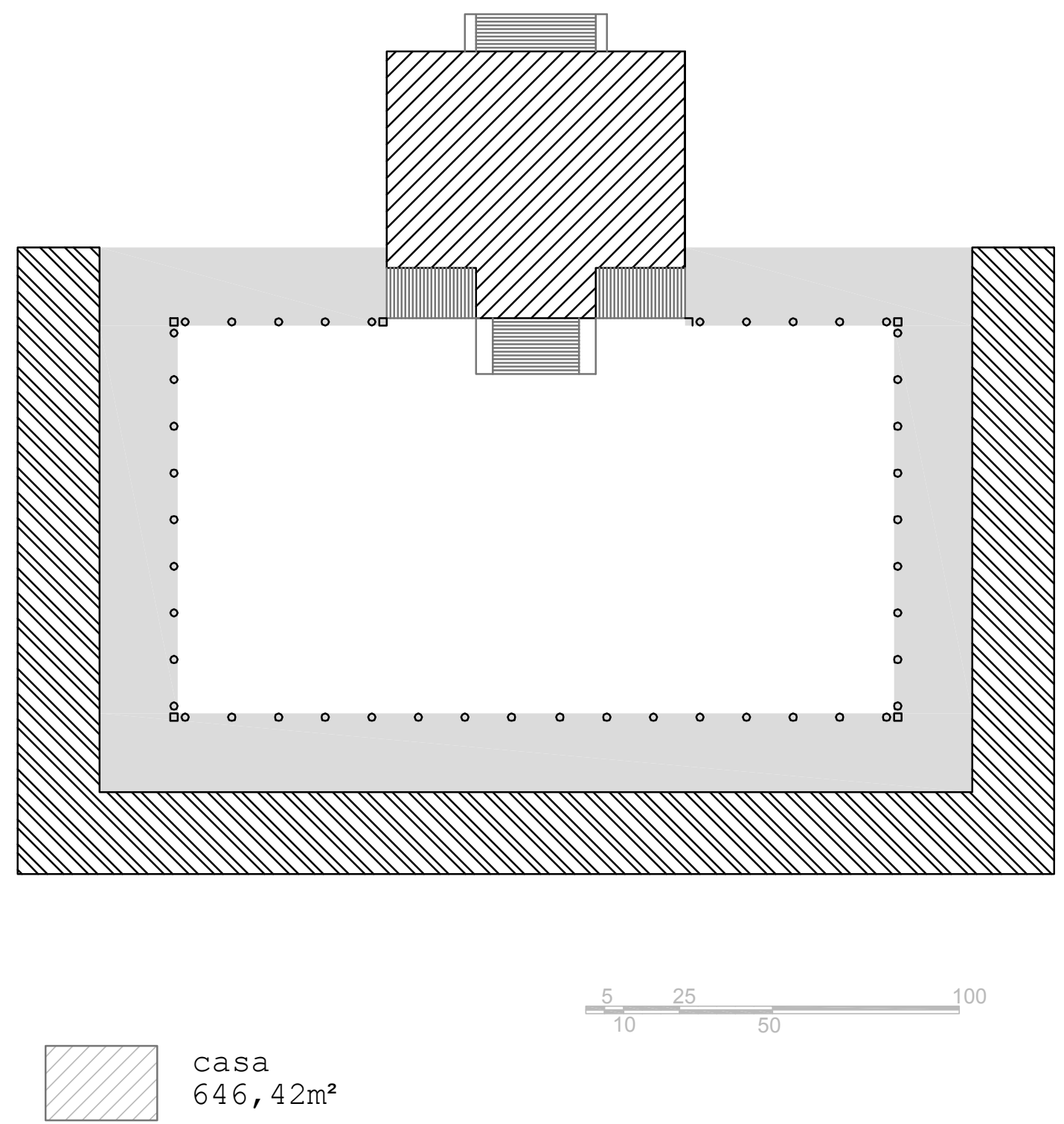

casa

$646,42 m^{2}$

barchessa

$1595,15 \mathrm{~m}^{2}$

arcadas

$1598,21 \mathrm{~m}^{2}$ 
Proporções dos cômodos

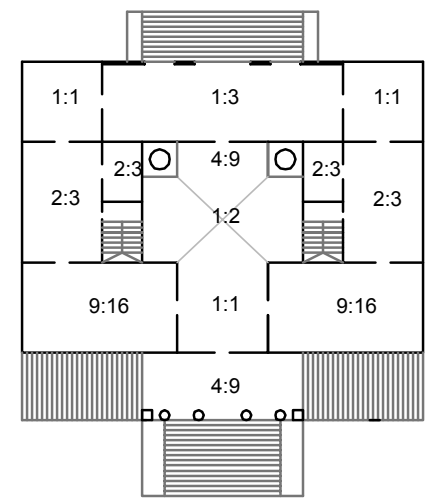

APARTAMENTOS - Tamanhos dos cômodos
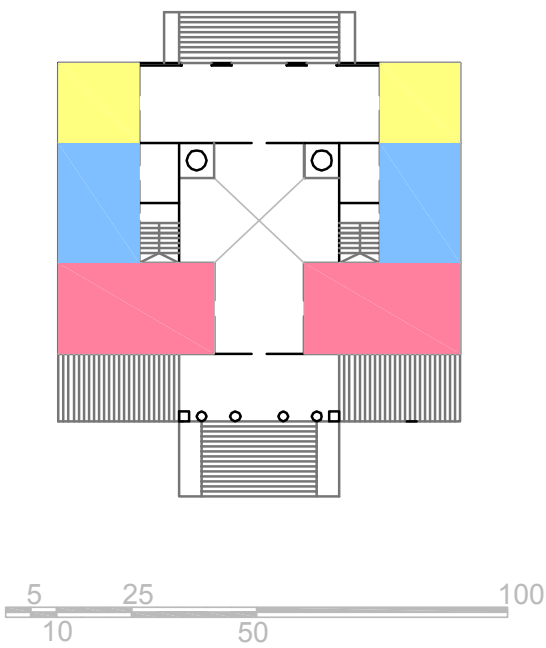

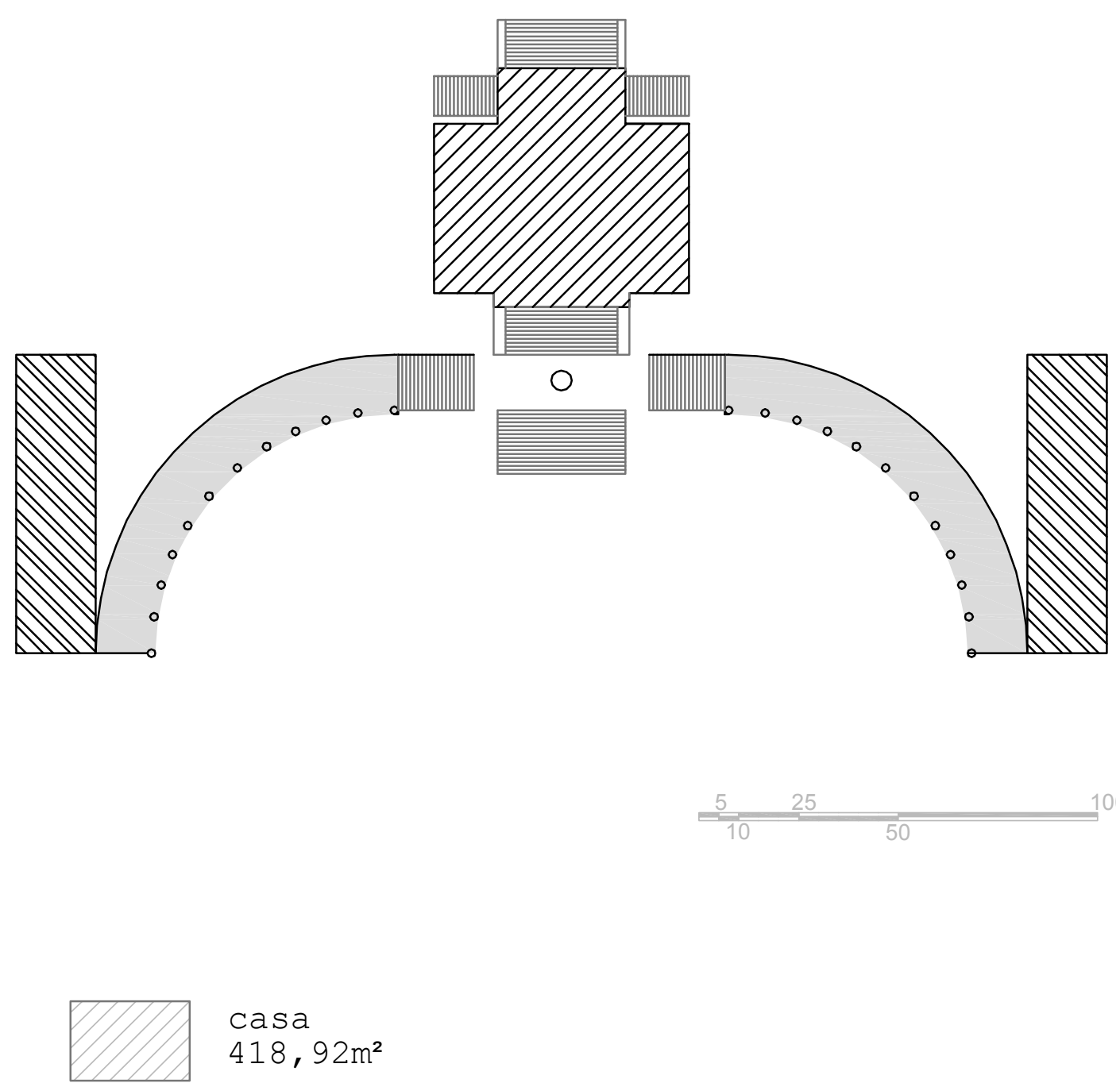

casa

$418,92 \mathrm{~m}^{2}$

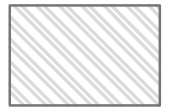

barchessa

$382,35 \mathrm{~m}^{2}$

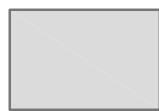

arcadas

$409,22 \mathrm{~m}^{2}$ 


\section{VILLA BADOER}

Proporções dos cômodos

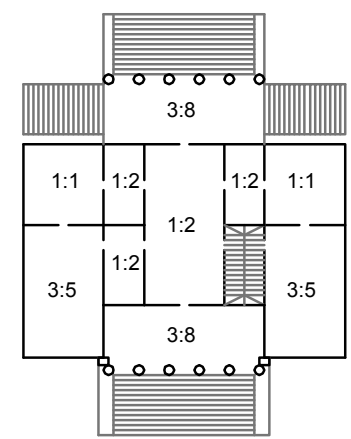

APARTAMENTOS - Tamanhos dos cômodos
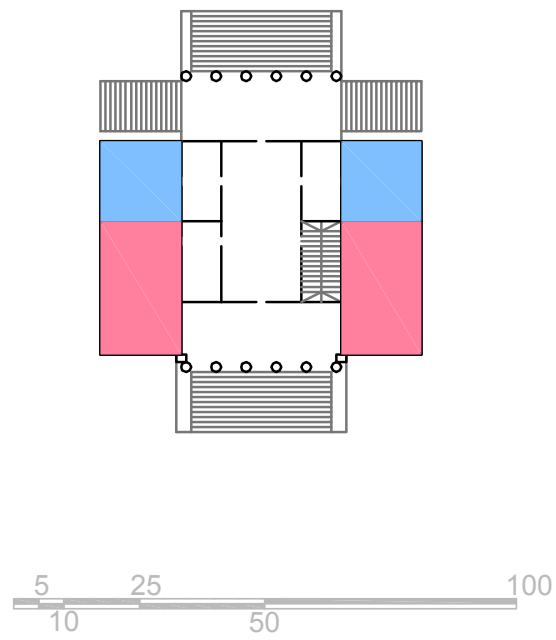

pequeno

médio

grande 

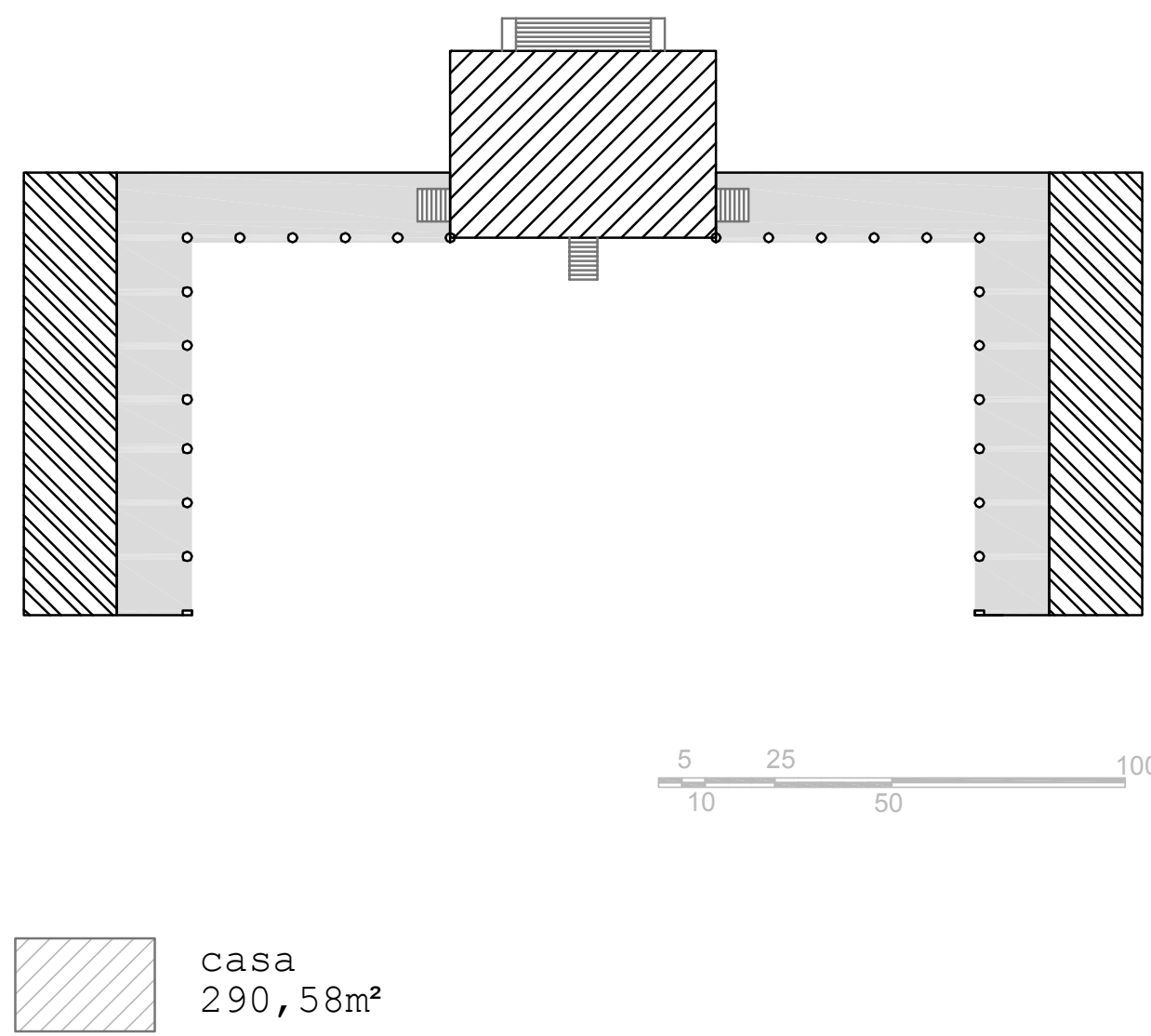

casa

$290,58 \mathrm{~m}^{2}$

barchessa

$484,31 \mathrm{~m}^{2}$

arcadas

$577,44 \mathrm{~m}^{2}$ 
Proporções dos cômodos

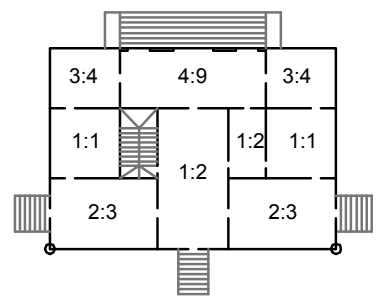

APARTAMENTOS - Tamanhos dos cômodos
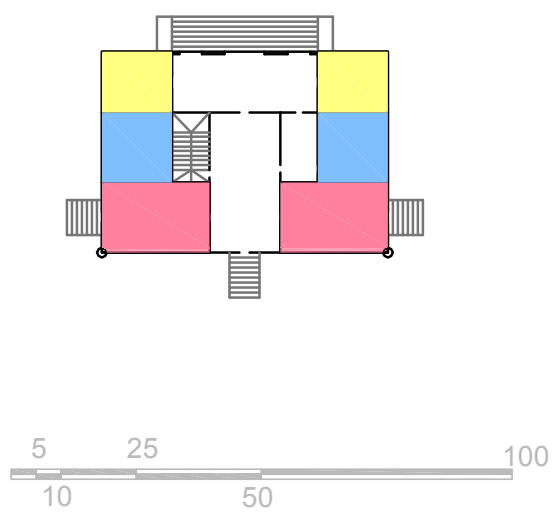

pequeno

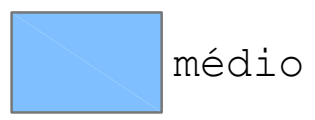

grande 
ÁREAS - Setores
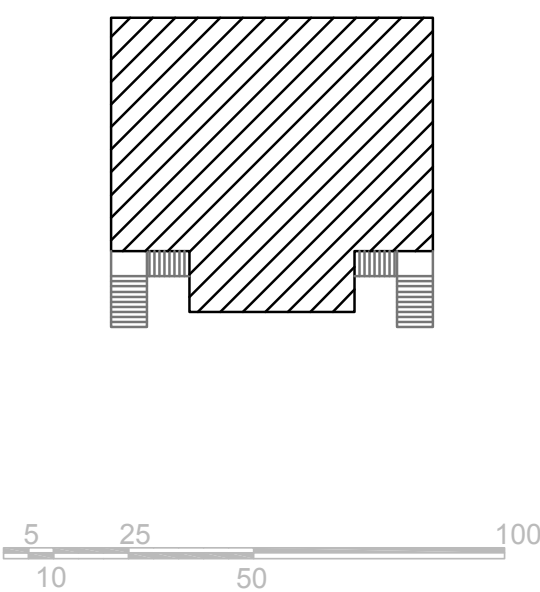

casa

$429,76 \mathrm{~m}^{2}$ 
Proporções dos cômodos

\begin{tabular}{|c|c|c|c|c|}
\hline $3: 4$ & $2: 3$ & $3: 4$ & $2: 3$ & $3: 4$ \\
\hline $1: 1$ & & $1: 2$ & & $1: 1$ \\
\hline & & & \\
\cline { 4 - 5 } & & & \\
\hline & & $1: 1$ & $2: 3$ \\
\hline
\end{tabular}

$3: 8$

APARTAMENTOS - Tamanhos dos cômodos
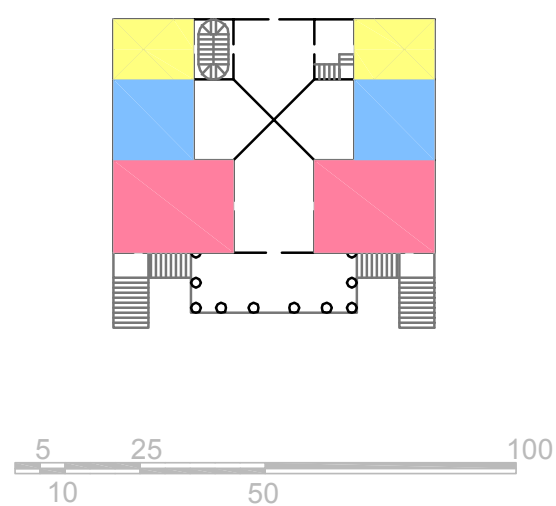

pequeno

médio

grande 


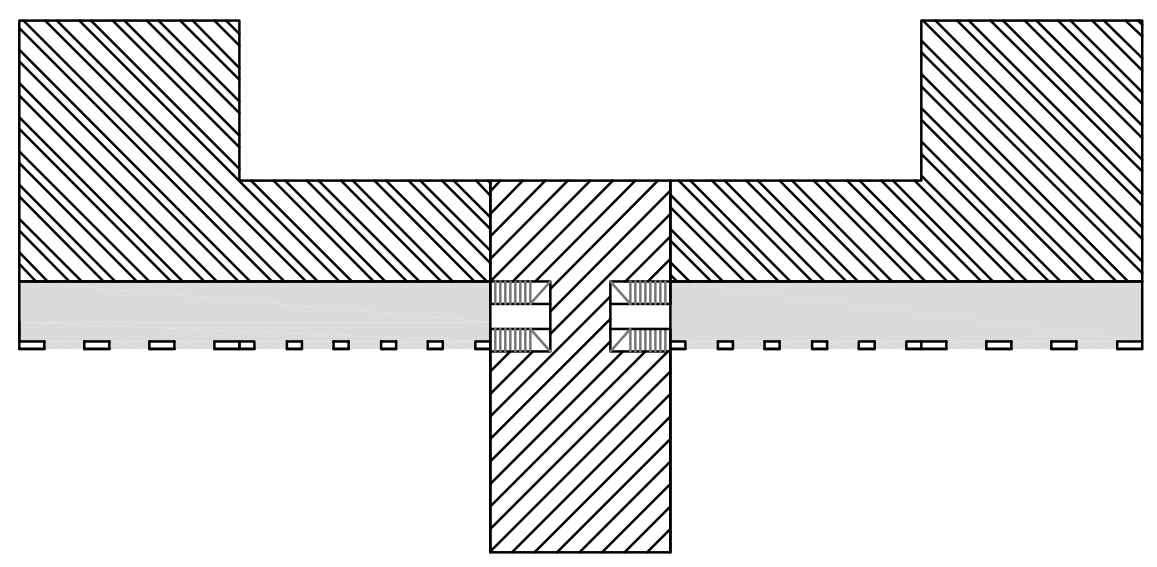

casa

$296,70 \mathrm{~m}^{2}$

barchessa

$838,10 \mathrm{~m}^{2}$

arcadas

$308,94 \mathrm{~m}^{2}$ 
Proporções dos cômodos

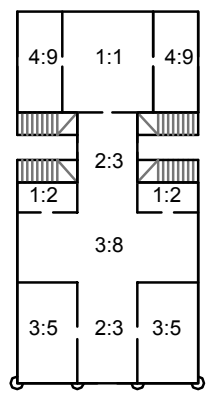

APARTAMENTOS - Tamanhos dos cômodos
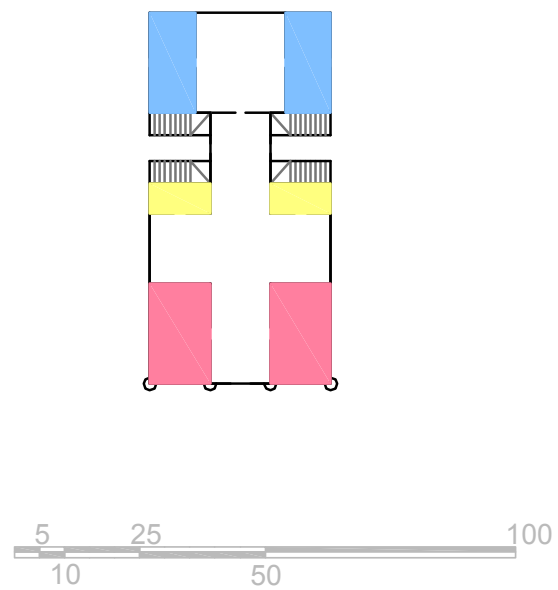

pequeno

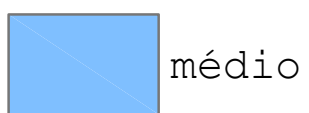

grande 
VILLA PISANI A MONTAGNANA

ÁREAS - Setores
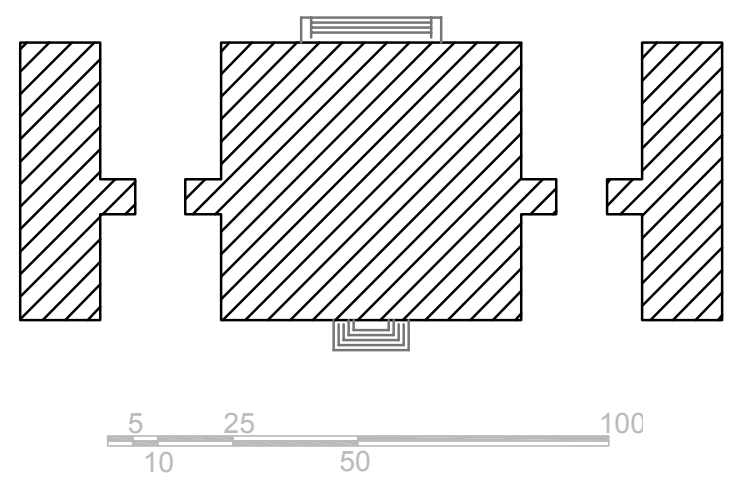

casa

$672,80 \mathrm{~m}^{2}$ 
Proporções dos cômodos
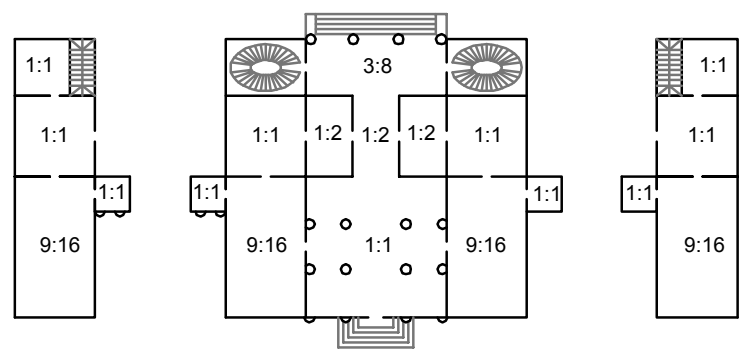

APARTAMENTOS - Tamanhos dos cômodos

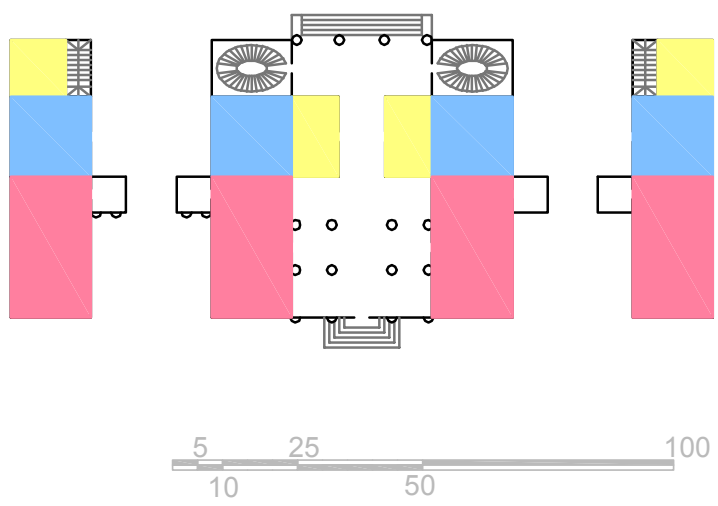

pequeno

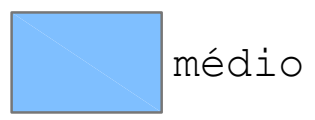

grande 
VILLA CORNARO

ÁREAS - Setores
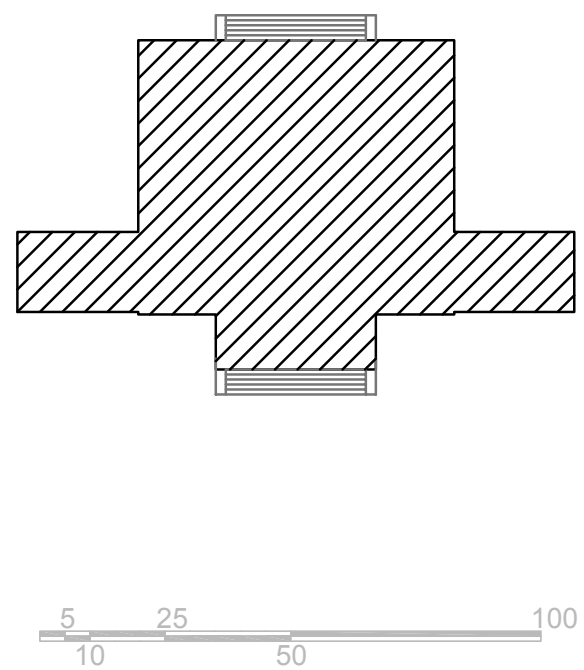

casa

$582,35 \mathrm{~m}^{2}$ 
Proporções dos cômodos

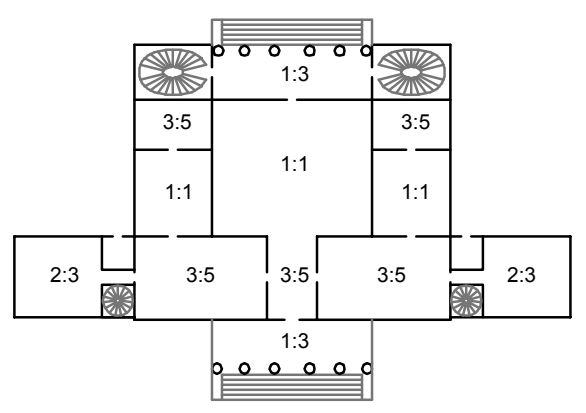

APARTAMENTOS - Tamanhos dos cômodos
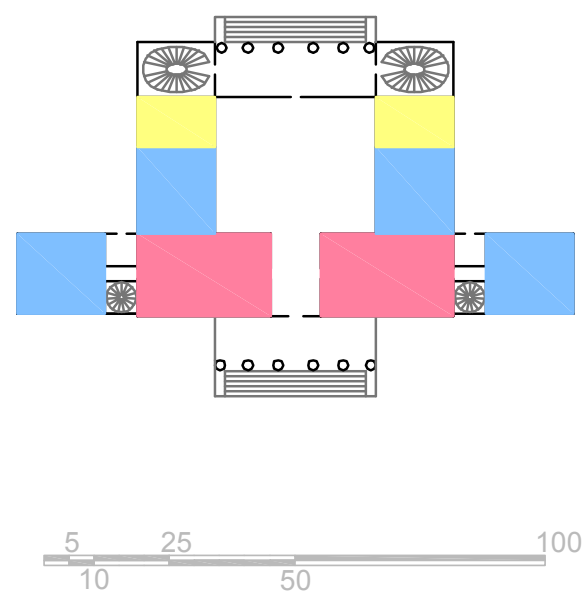

pequeno

médio

grande 


$$
\text { ÁREAS - Setores }
$$
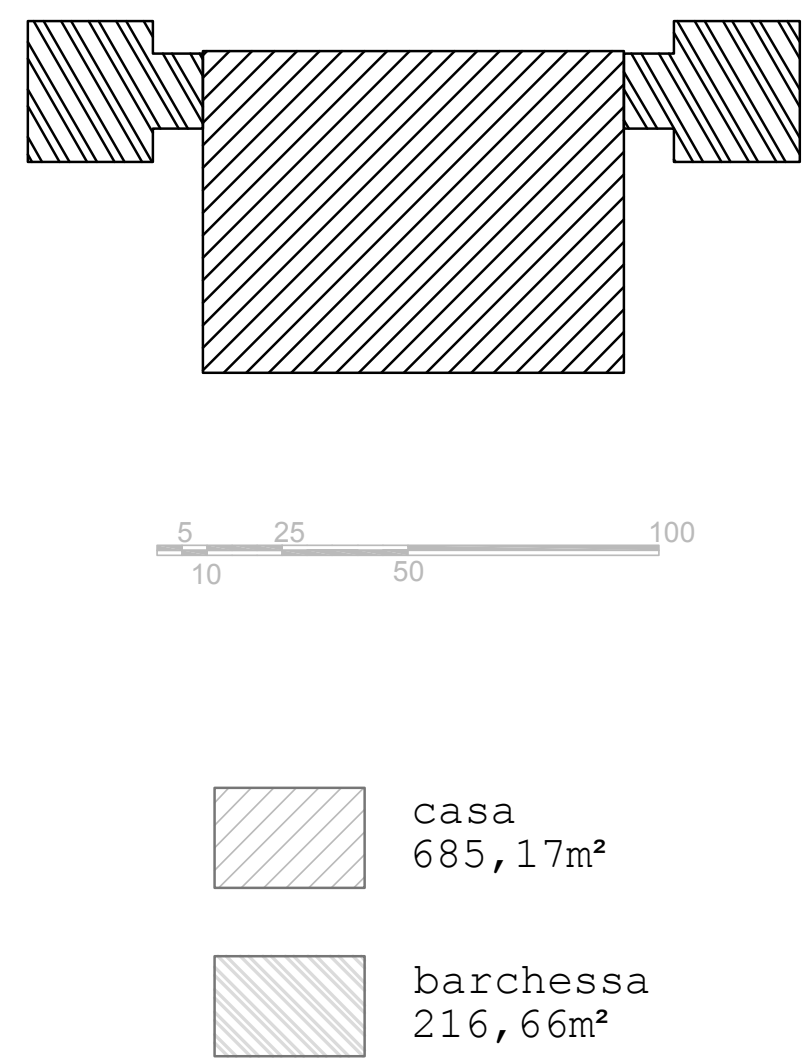
Proporções dos cômodos

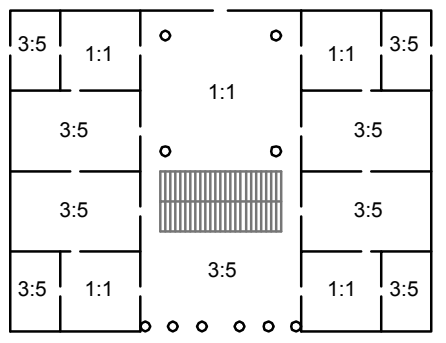

APARTAMENTOS - Tamanhos dos cômodos
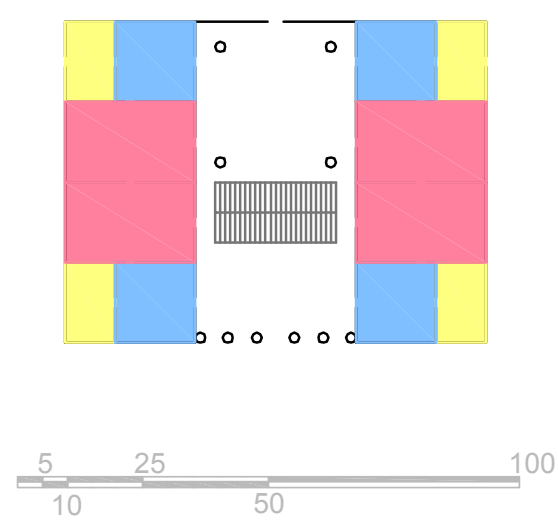

pequeno

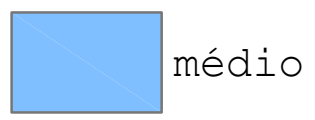

grande 


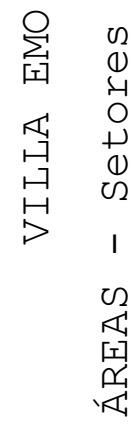
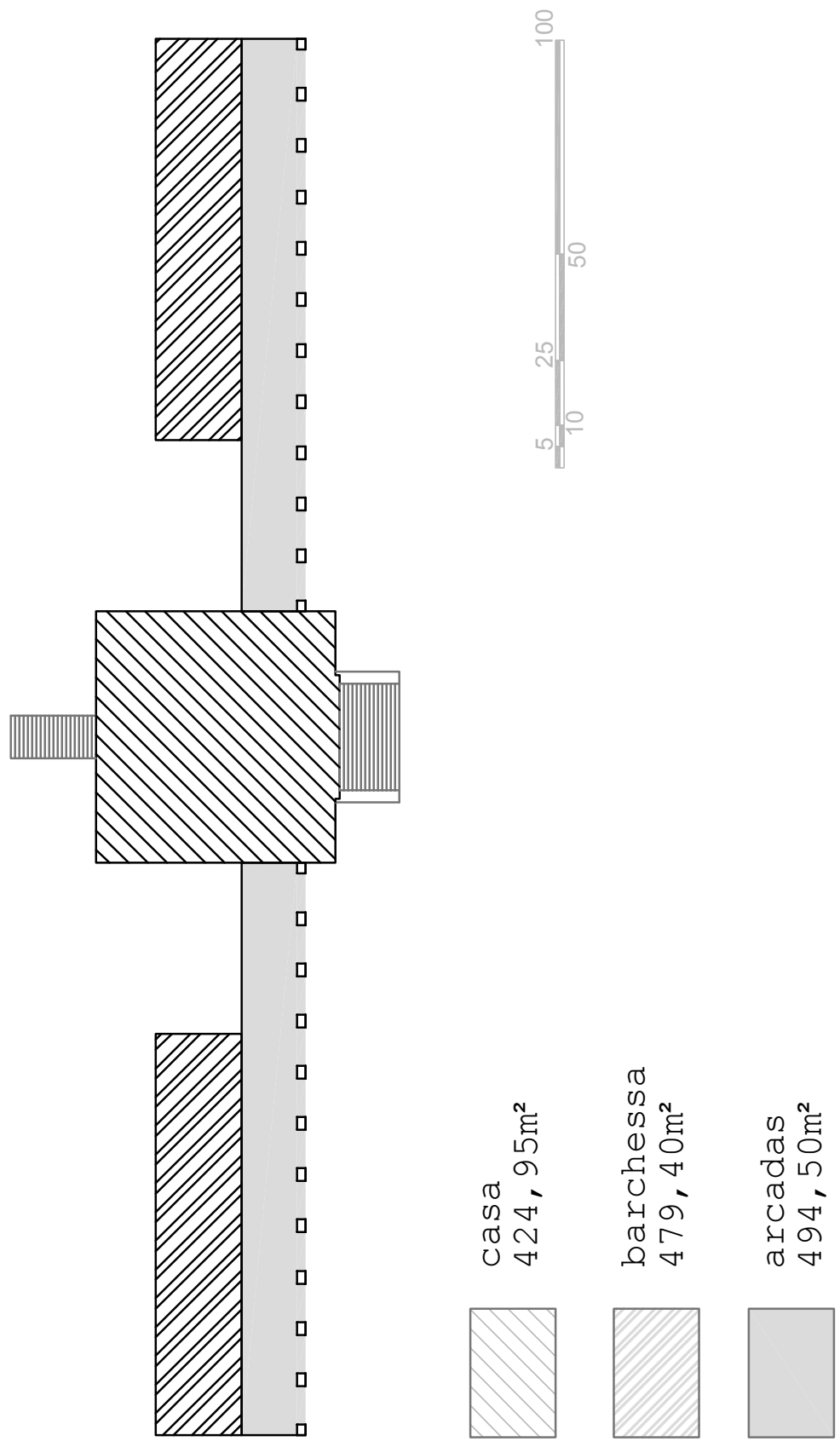
Proporções dos cômodos

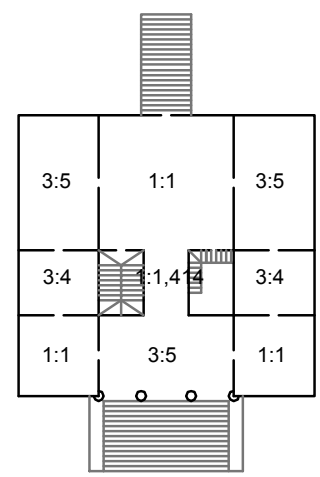

APARTAMENTOS - Tamanhos dos cômodos
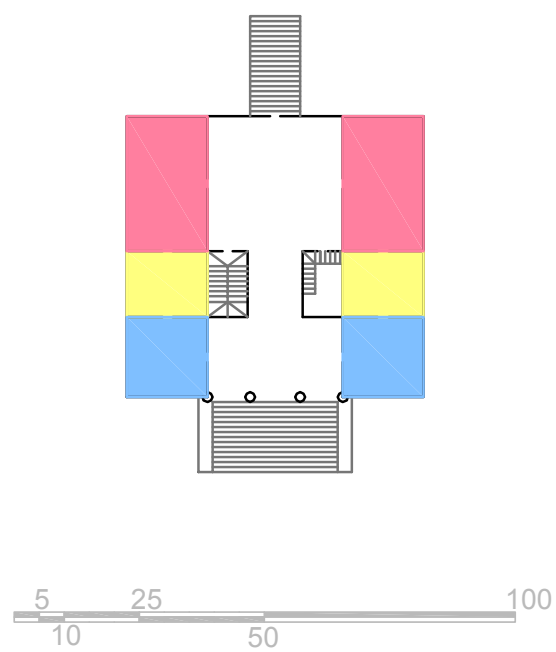

pequeno

médio

grande 
ÁREAS - Setores

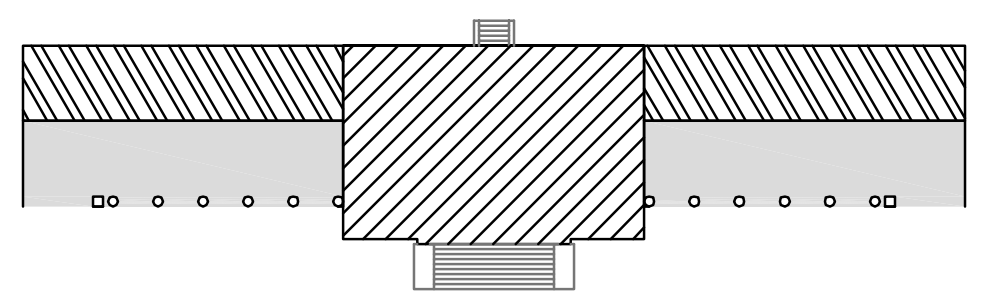

$\stackrel{5}{=25} 100$

casa

$289,29 \mathrm{~m}^{2}$

barchessa

$244,80 \mathrm{~m}^{2}$

arcadas

$271,56 \mathrm{~m}^{2}$ 
Proporções dos cômodos

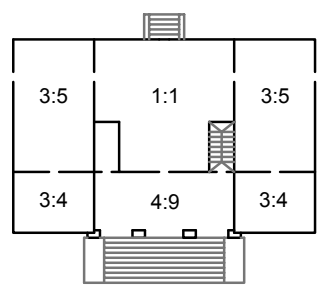

APARTAMENTOS - Tamanhos dos cômodos
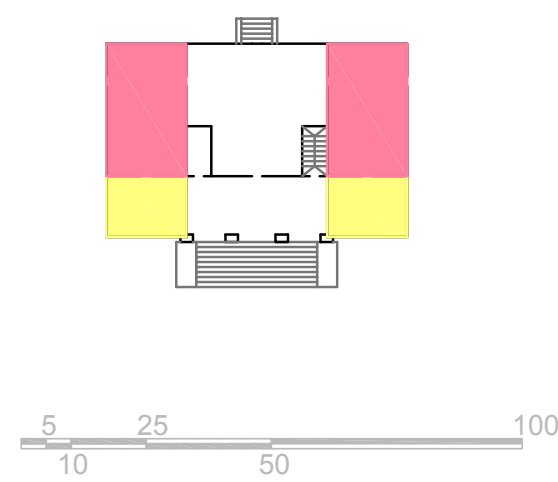

pequeno

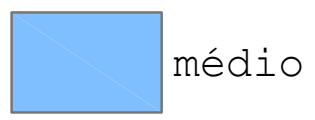

grande 
VILLA RAGONA

ÁREAS - Setores
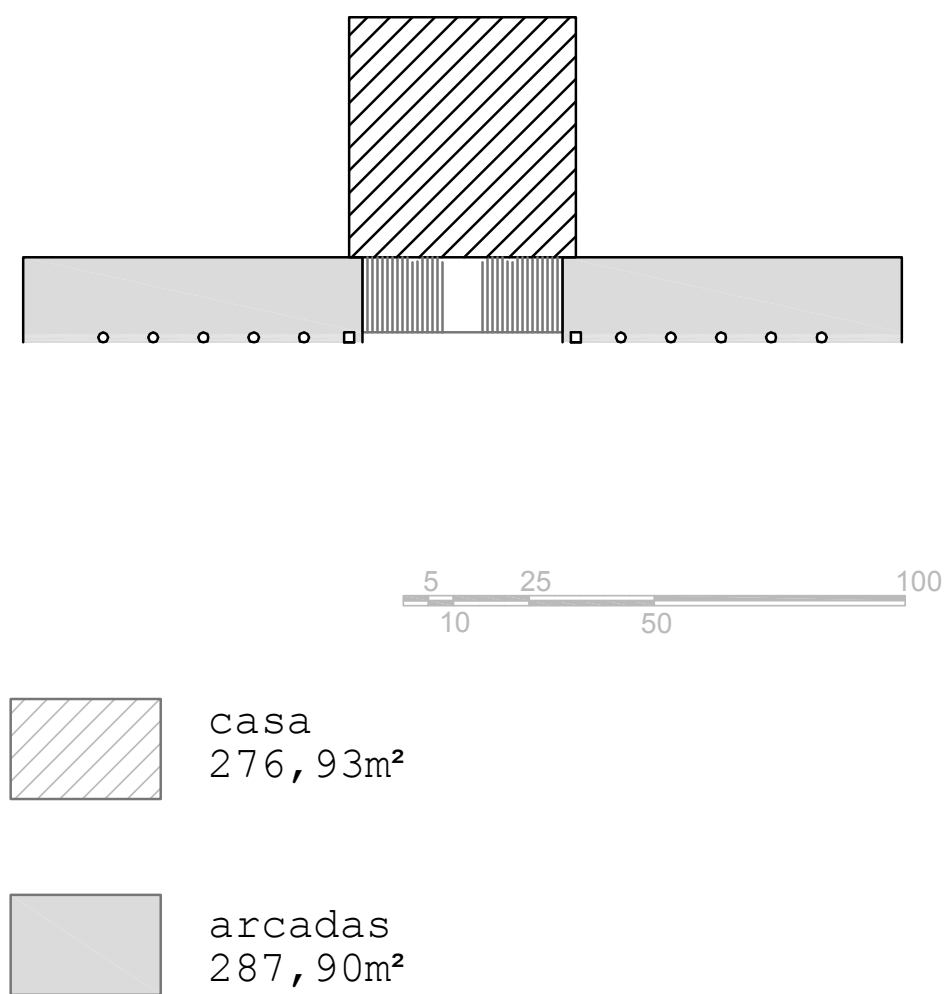
Proporções dos cômodos

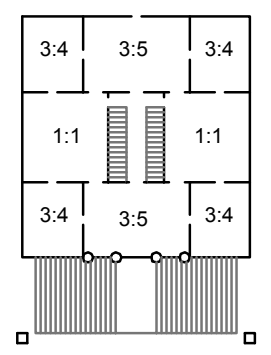

APARTAMENTOS - Tamanhos dos cômodos

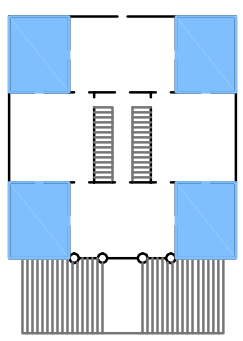

$\begin{array}{lll}\frac{5}{10} \quad 25 & 100\end{array}$

pequeno

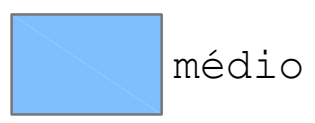

grande 

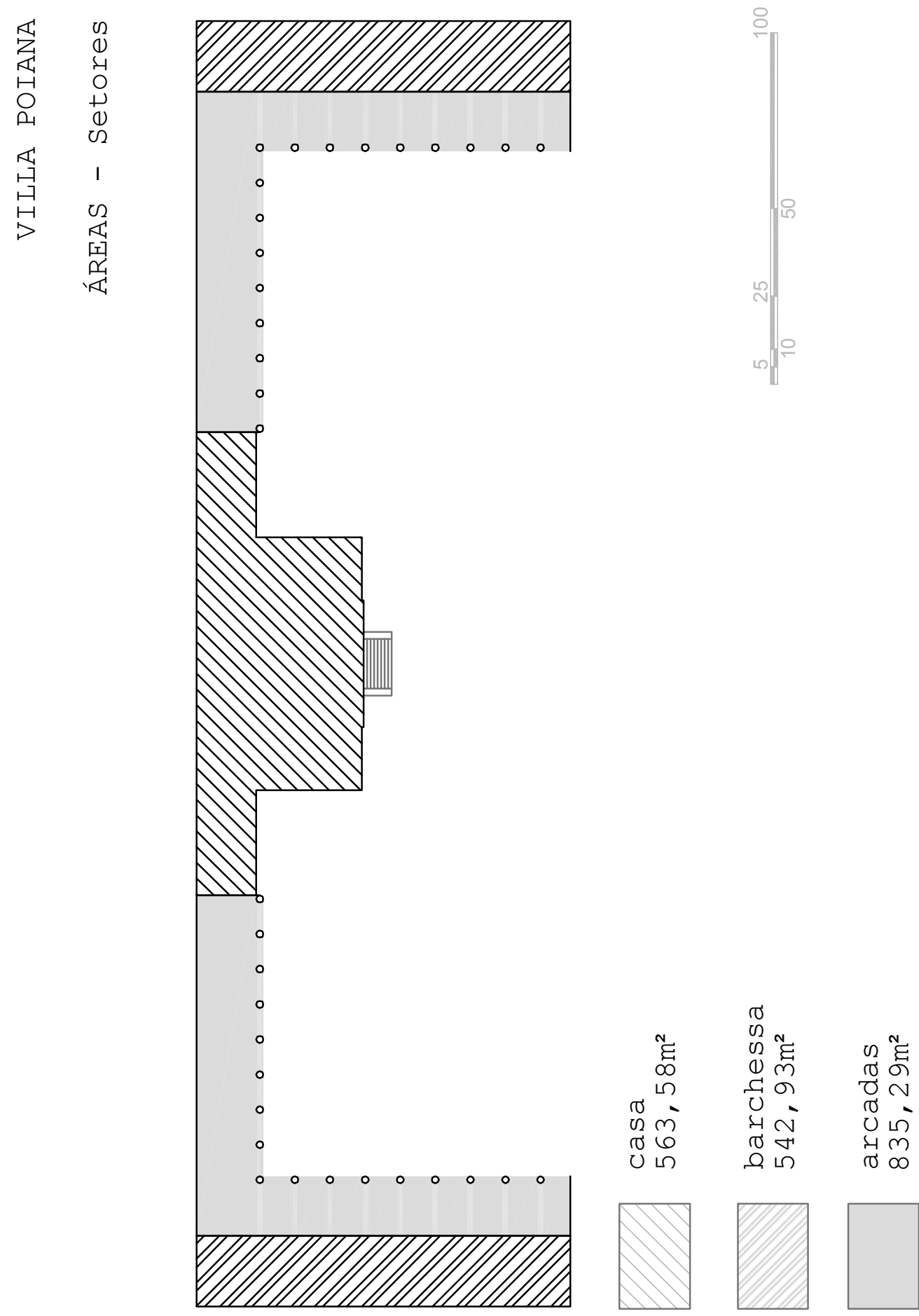
Proporções dos cômodos

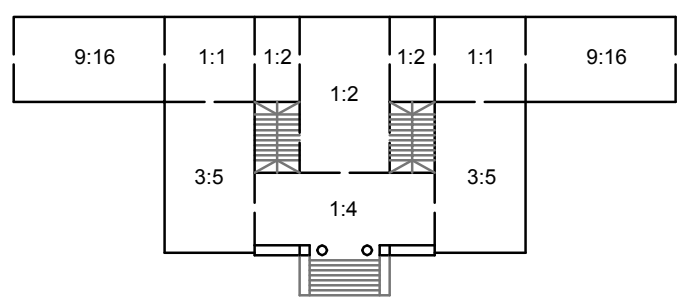

APARTAMENTOS - Tamanhos dos cômodos
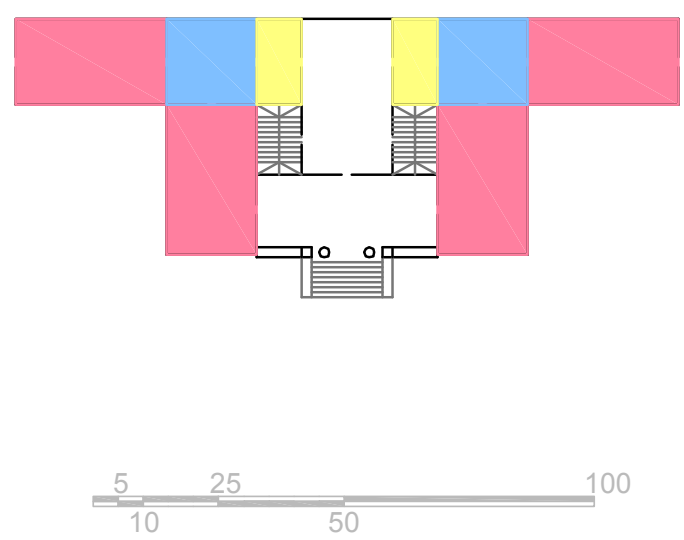

pequeno

médio

grande 
VILLA VALMARANA

ÁREAS - Setores
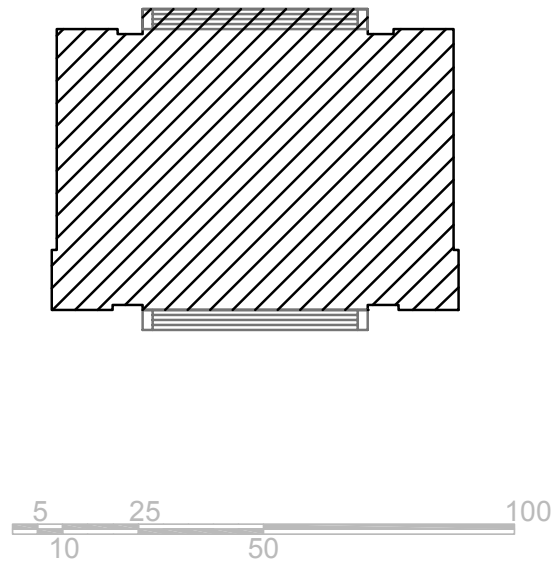

casa

$587,03 m^{2}$ 
VILLA VALMARANA

Proporções dos cômodos

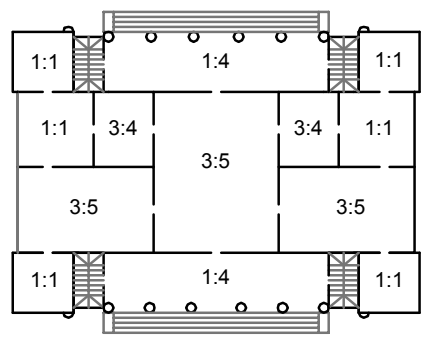

APARTAMENTOS - Tamanhos dos cômodos
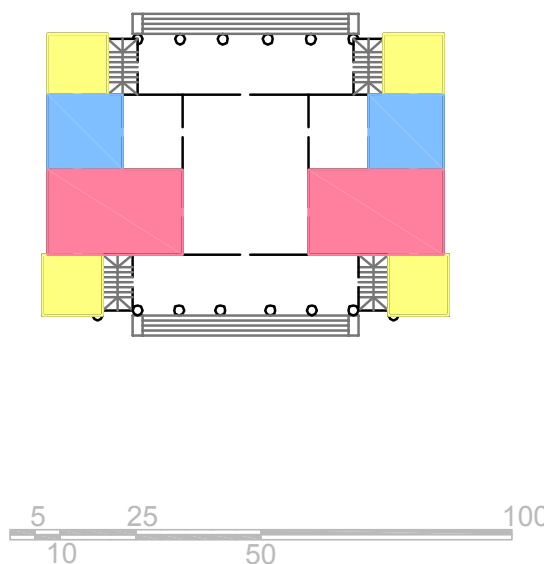

pequeno

médio

grande 


\section{ÁREAS - Setores}

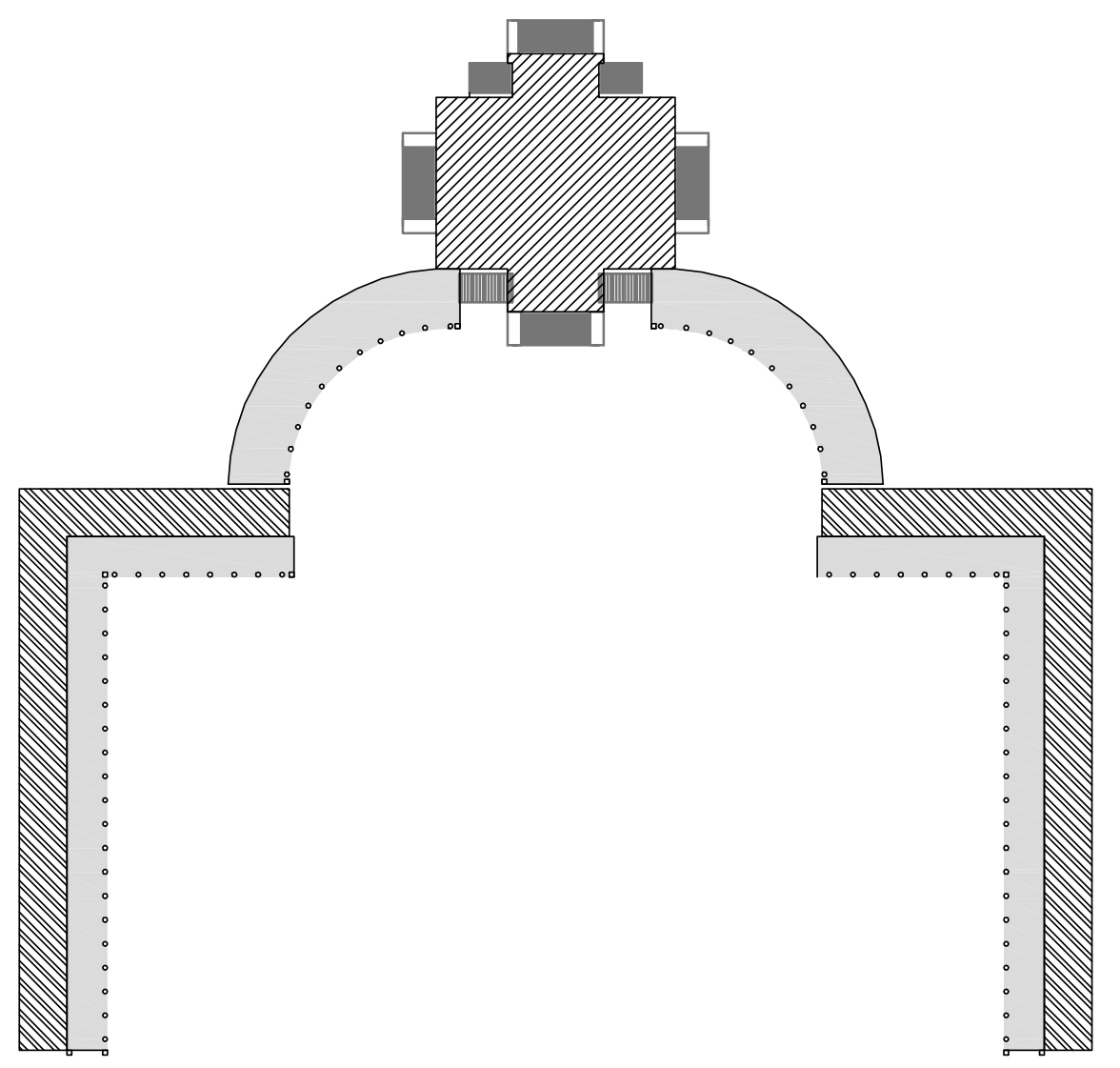

casa

\begin{tabular}{llll}
5 & 25 & 100 & 200 \\
\hline 10 & 50 &
\end{tabular}

$1094,02 \mathrm{~m}^{2}$

barchessa

$1672,13 \mathrm{~m}^{2}$

arcadas

$2053,20 \mathrm{~m}^{2}$ 


\section{VILLA TRISSINO}

Proporções dos cômodos

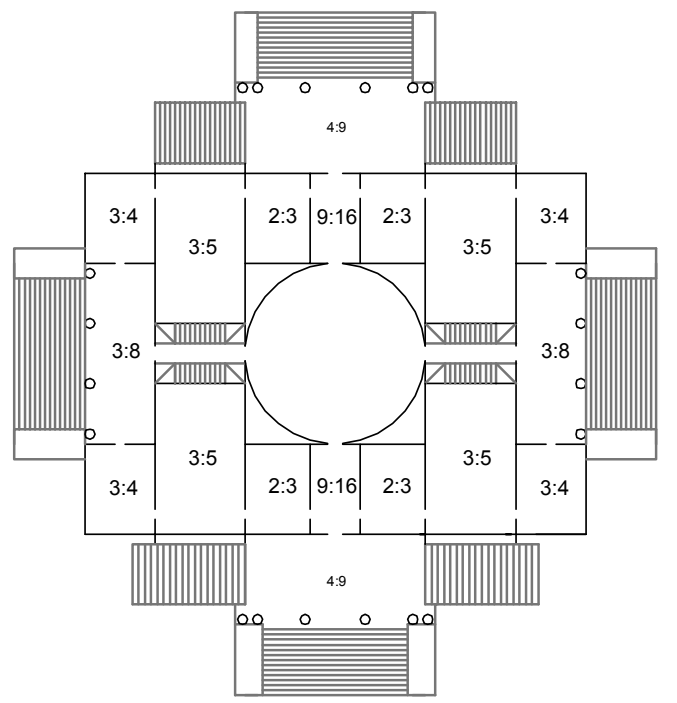

APARTAMENTOS - Tamanhos dos cômodos
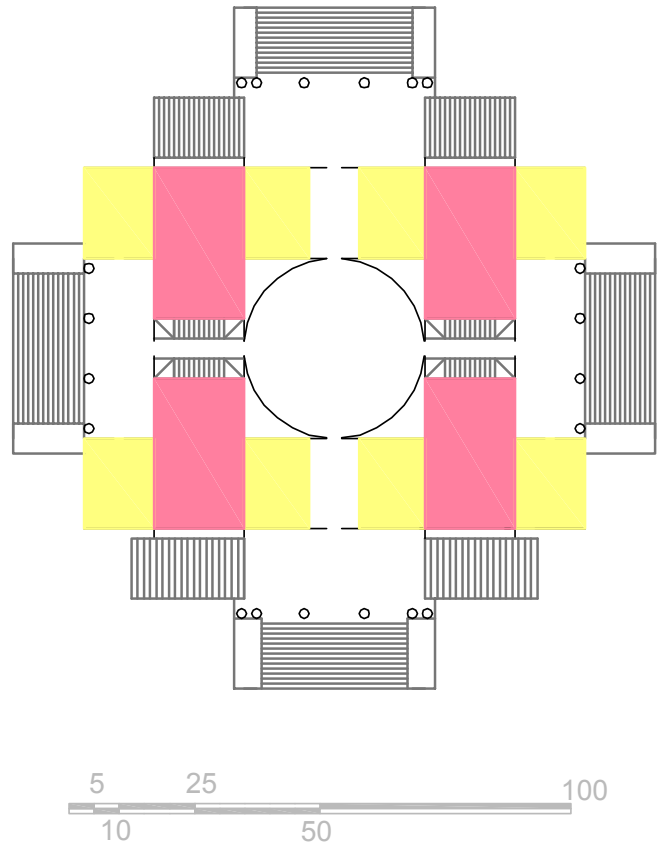


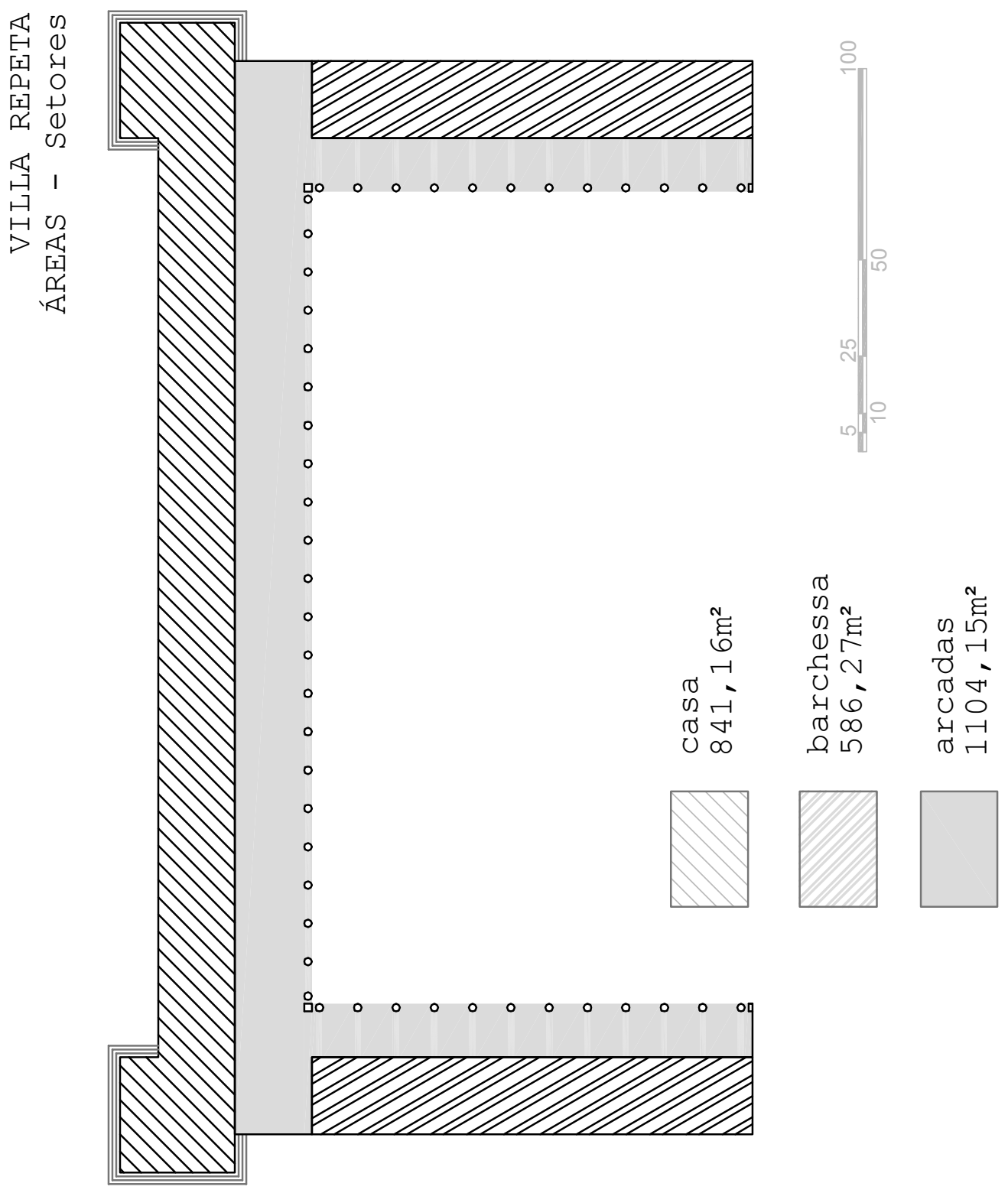



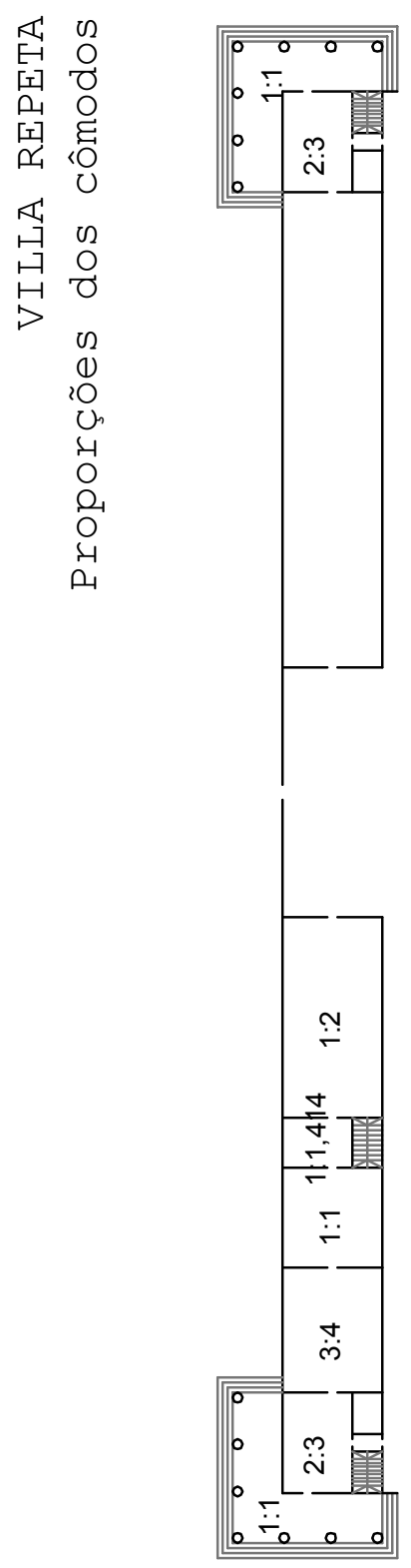

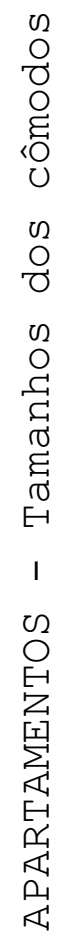
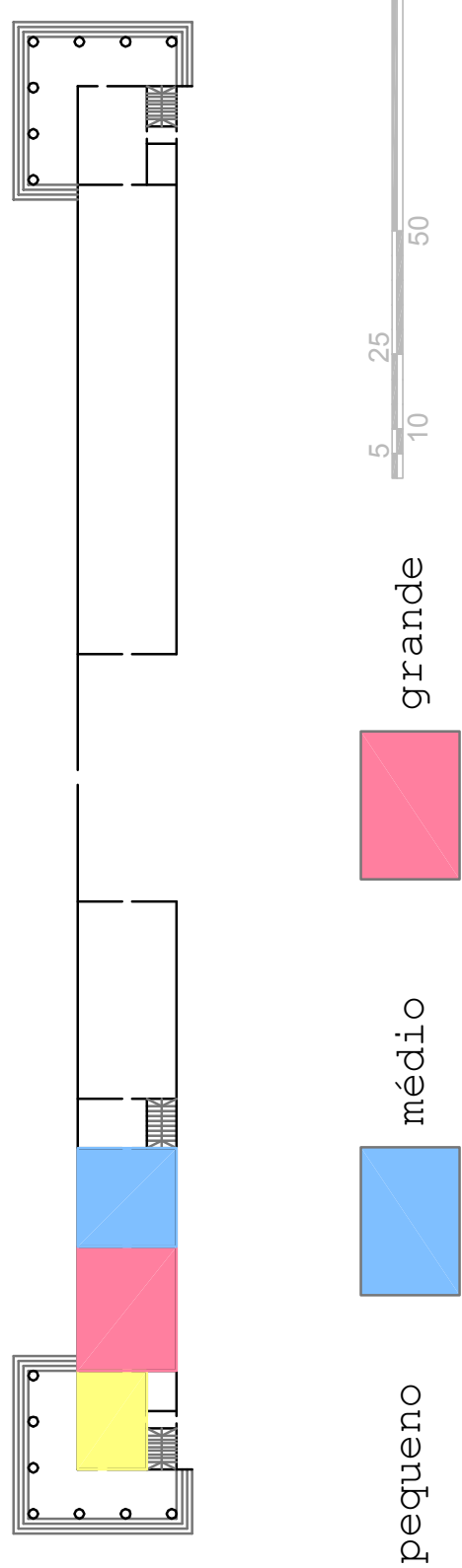

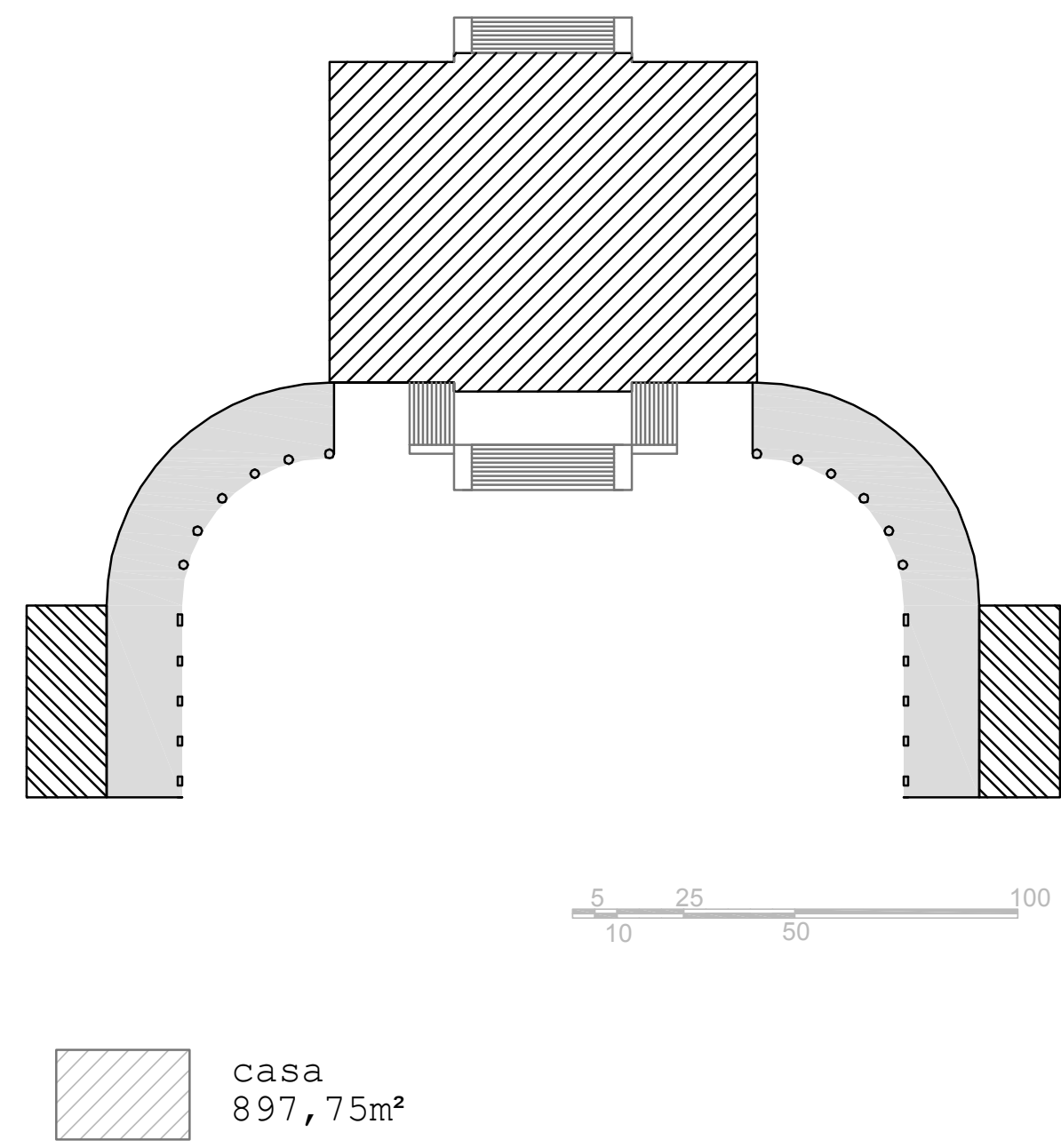

casa

$897,75 \mathrm{~m}^{2}$

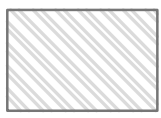

barchessa

$197,29 \mathrm{~m}^{2}$

arcadas

$473,28 \mathrm{~m}^{2}$ 
VILLA THIENE CICOGNA

Proporções dos cômodos

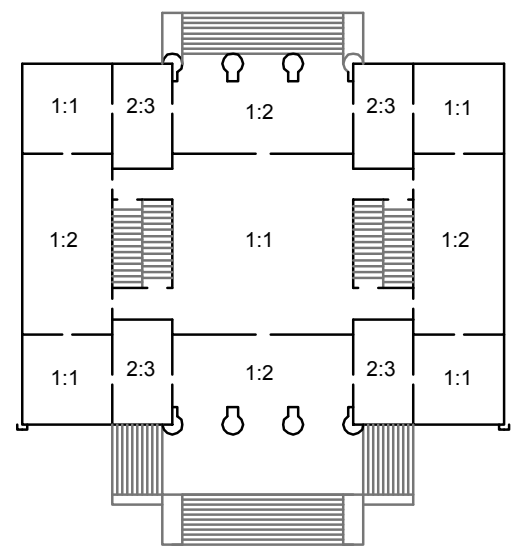

ApARtAmentos - Tamanhos dos cômodos
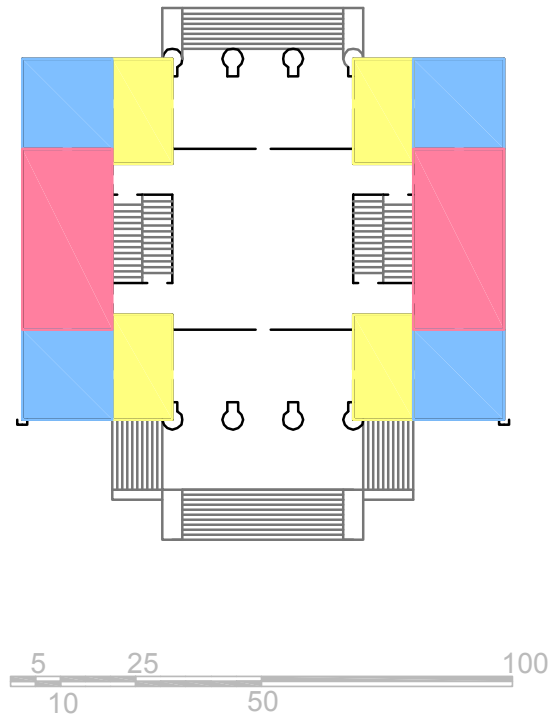

pequeno

médio

grande 

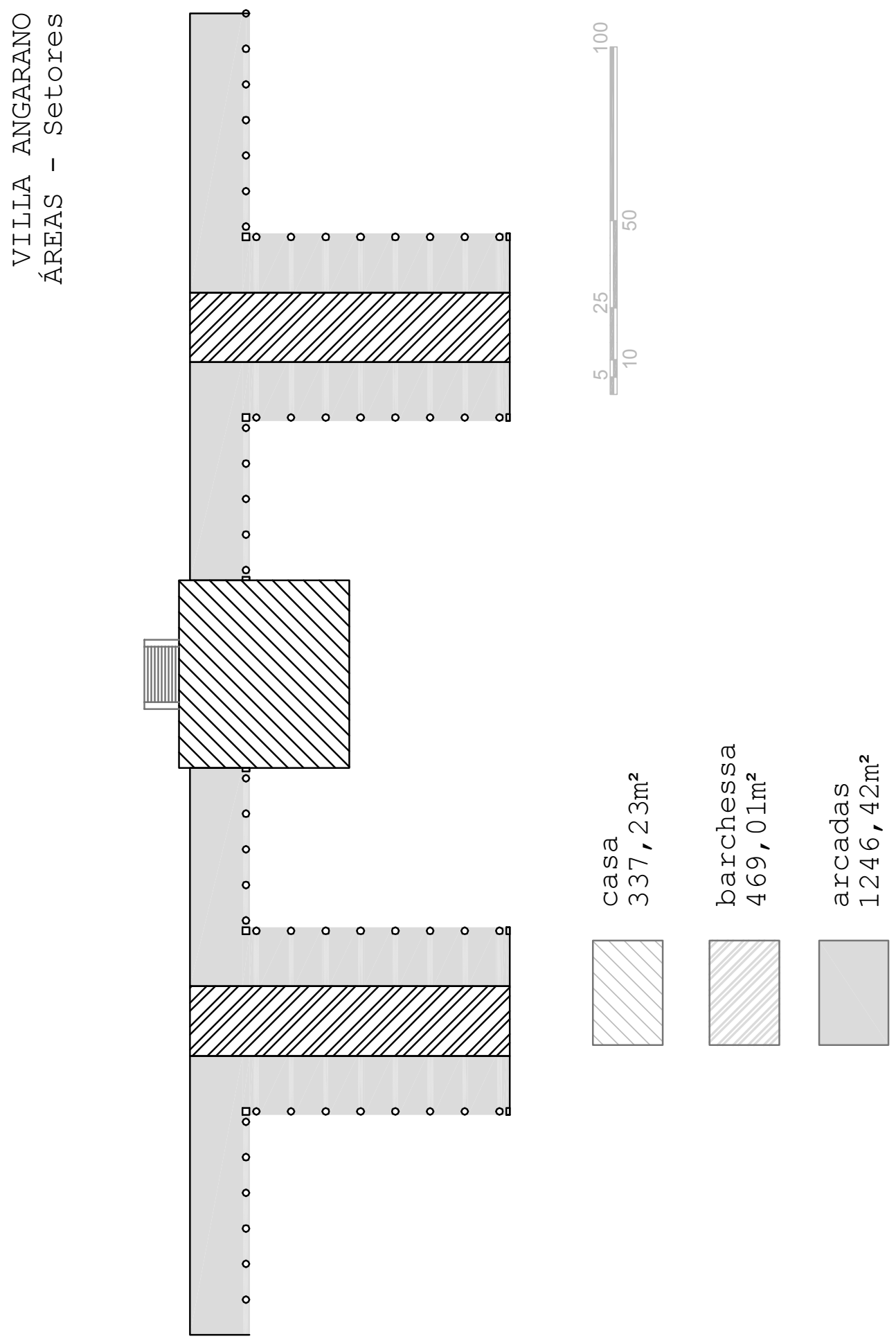
Proporções dos cômodos

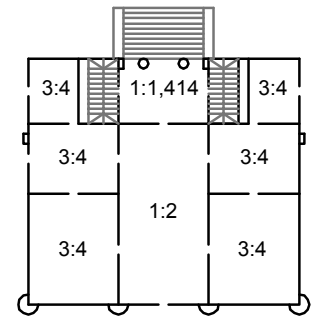

APARTAMENTOS - Tamanhos dos cômodos
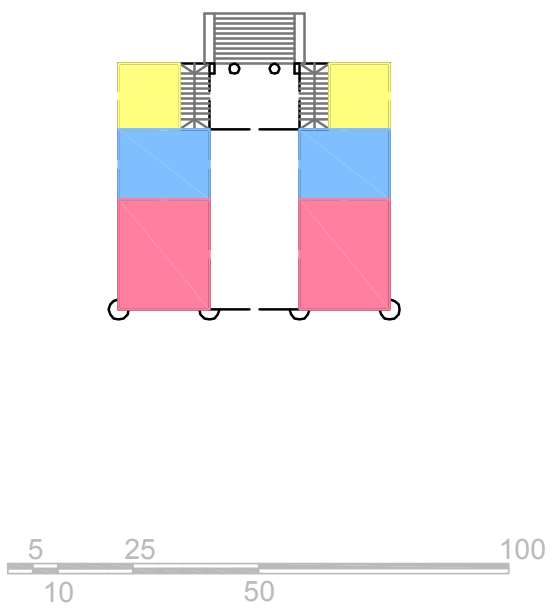

pequeno

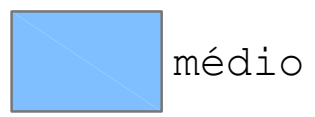

grande 


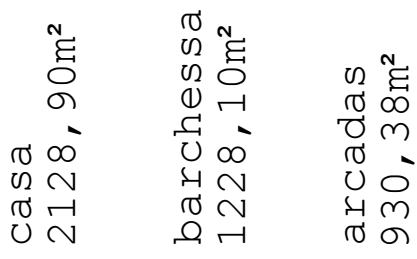

$\begin{array}{ll}0 & 0 \\ 1 & 0 \\ 2 & 4 \\ 2 & 0 \\ -1 & 0 \\ 0 & + \\ 0 & 0 \\ 0 & 0\end{array}$

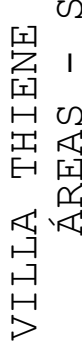

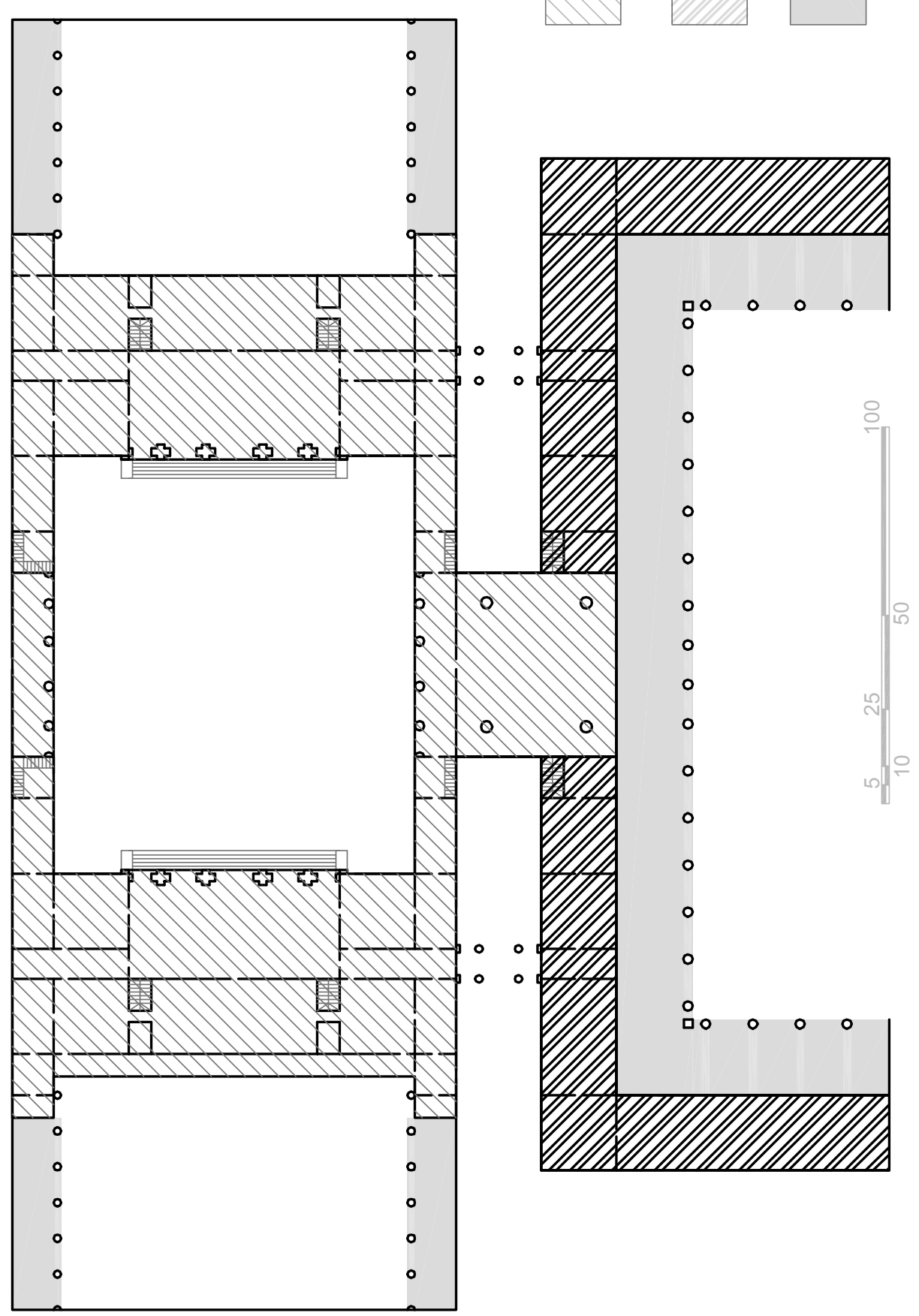


VILLA THIENE QUINTO

Proporções dos cômodos

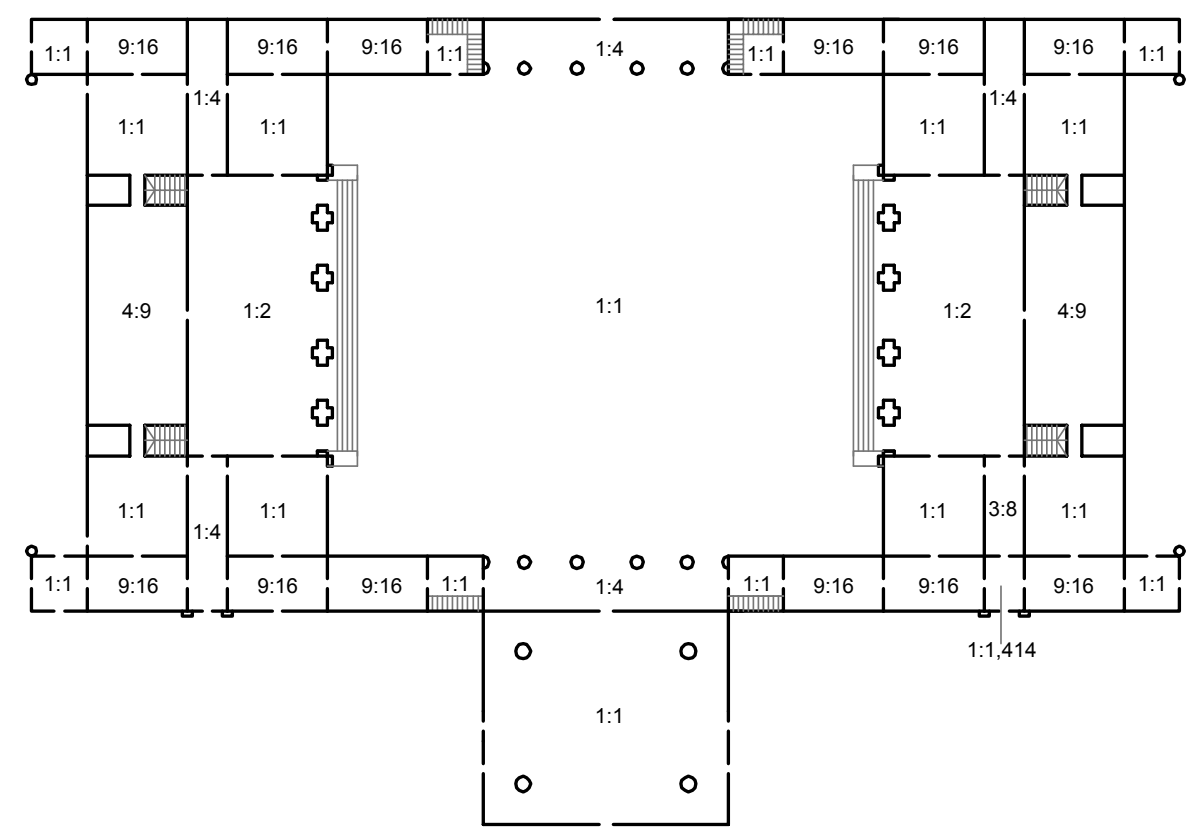

APARTAMENTOS - Tamanhos dos cômodos

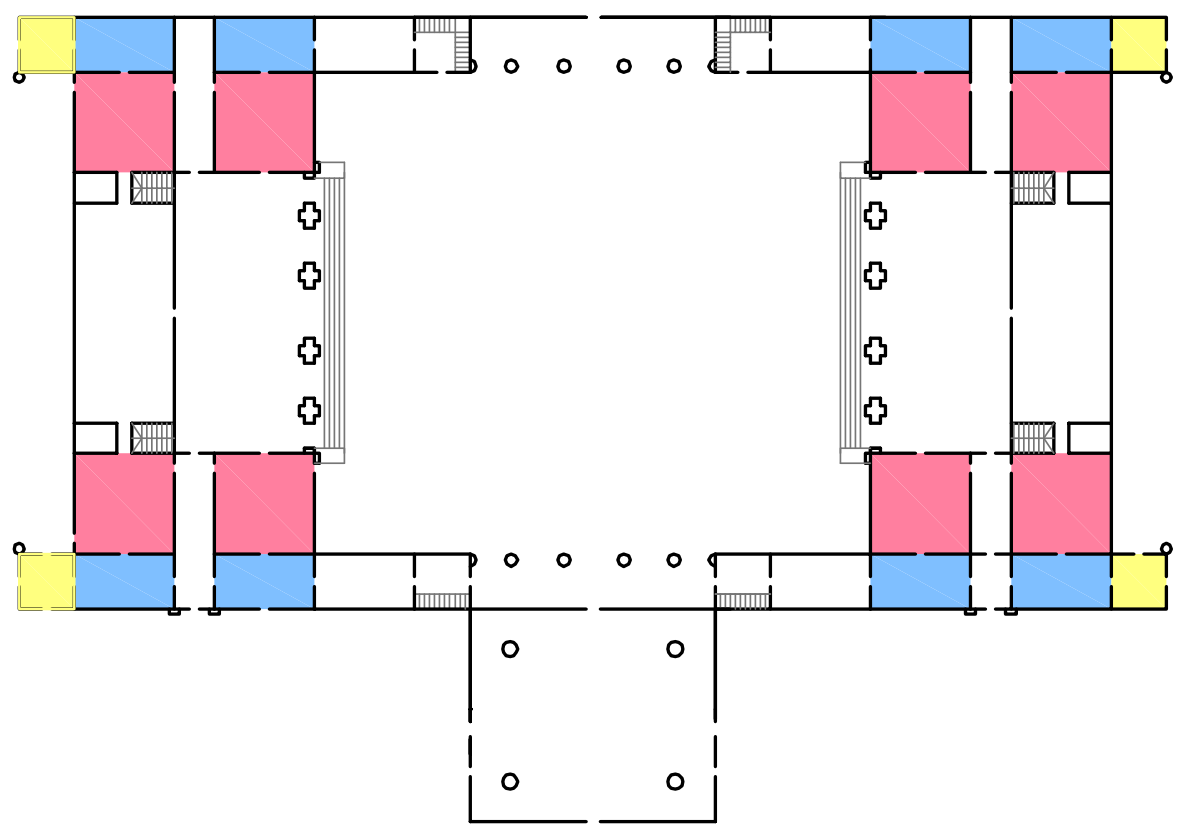




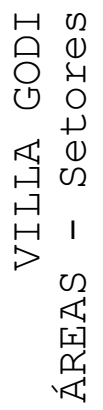
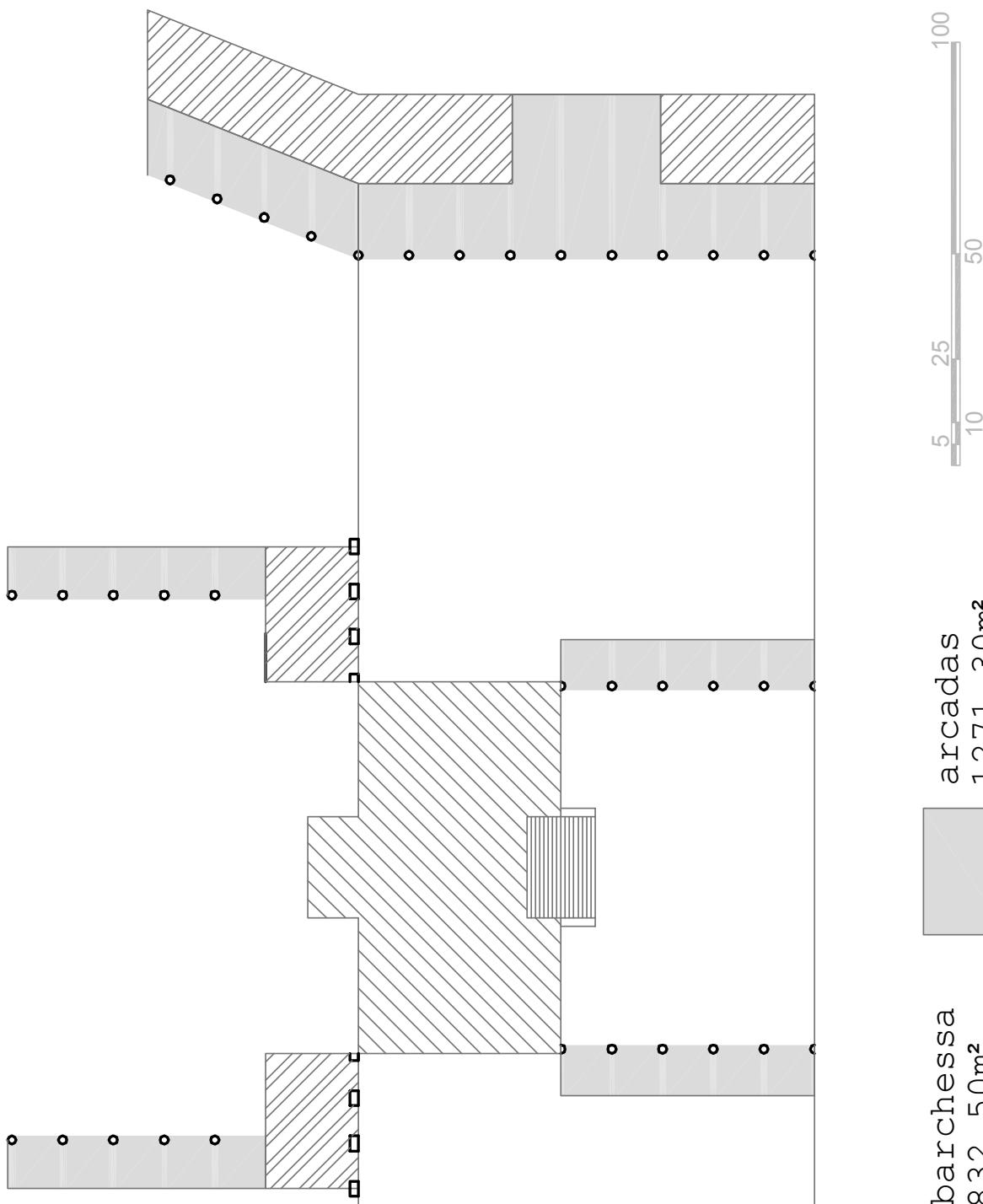

थ $\stackrel{N}{్}$ ro $\mathrm{m}$ ठ

U

$4 N$ $\sigma$

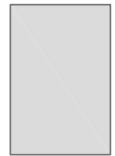

$\sigma$

U $~ N$

(1) ह 도 $4 N$ $\sigma \mathrm{m}$ ㅇ $\infty$
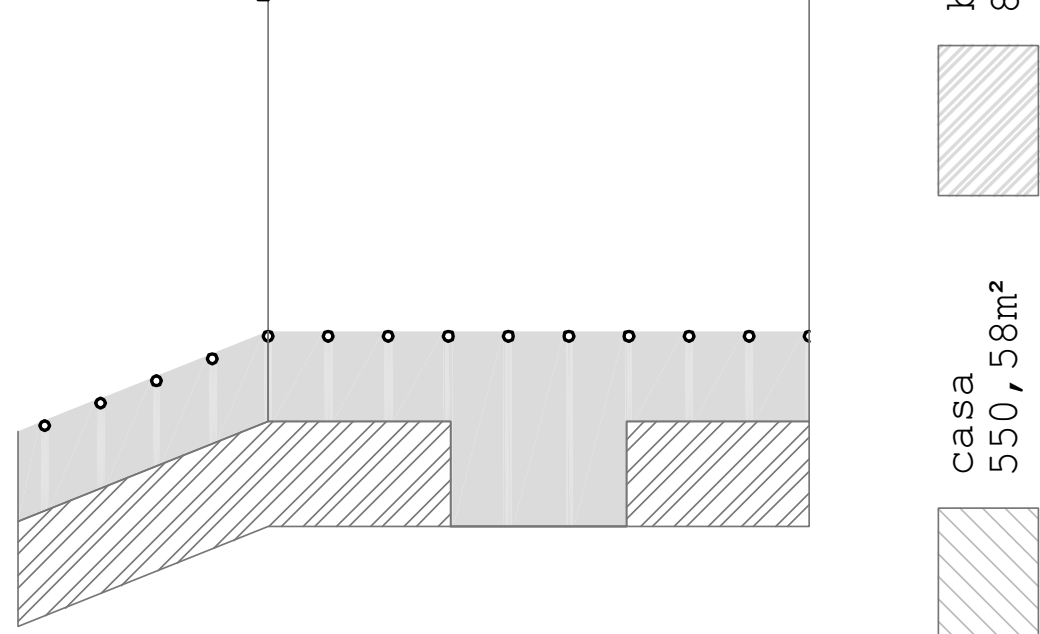

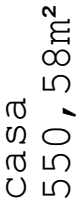


Proporções dos cômodos

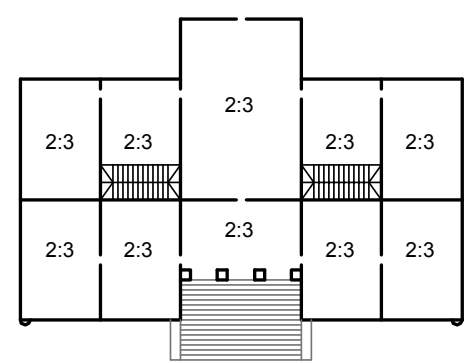

APARTAMENTOS - Tamanhos dos cômodos
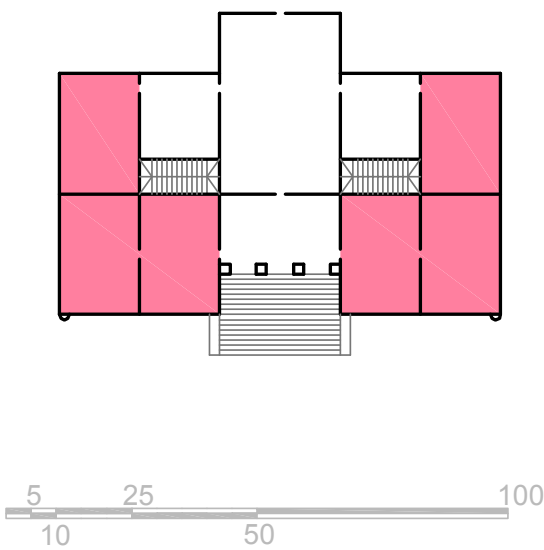
ÁREAS - Setores
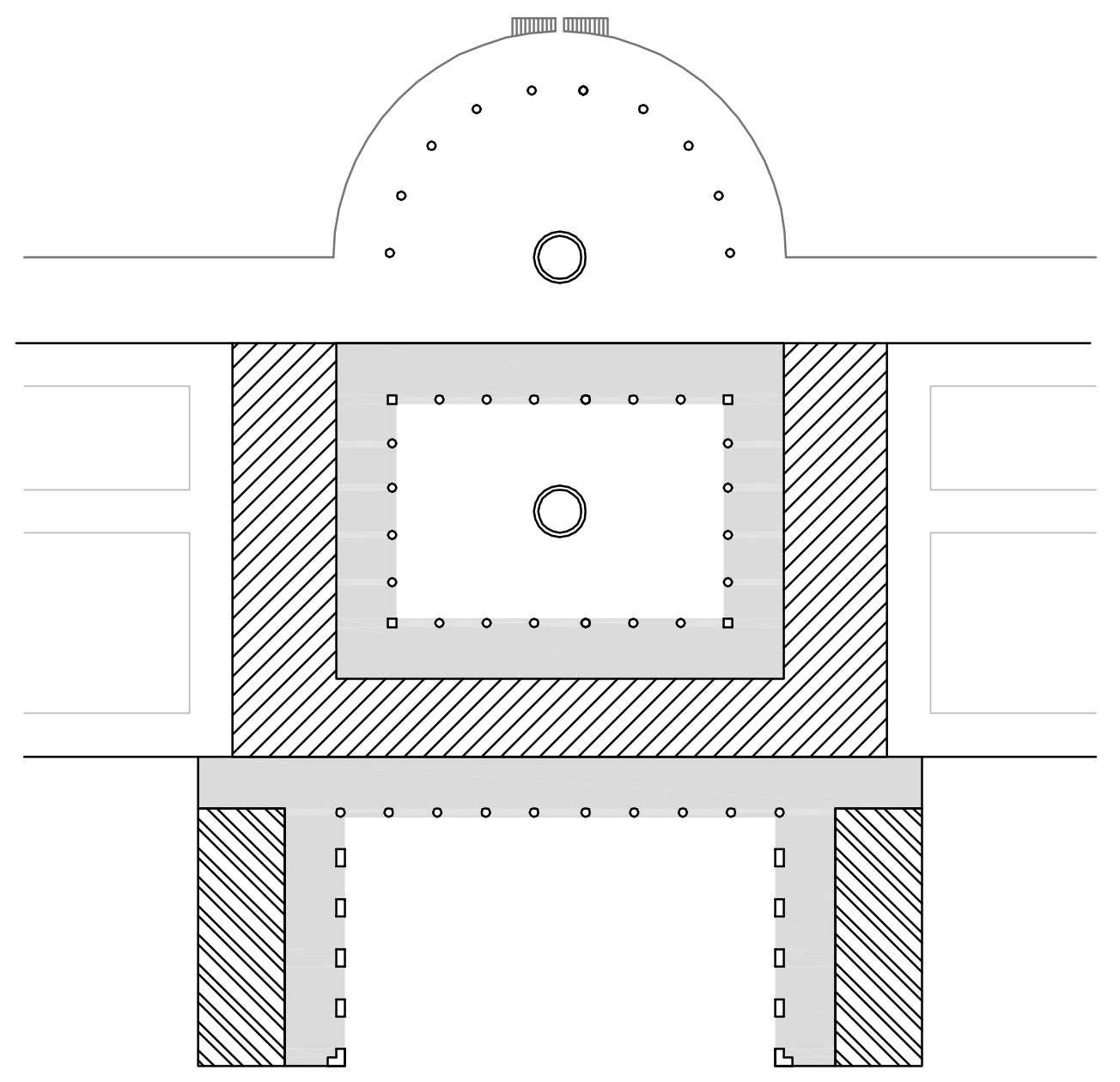

casa

$1375,43 \mathrm{~m}^{2}$

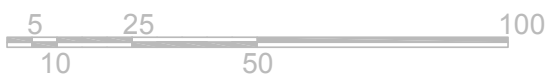

barchessa

$305,88 \mathrm{~m}^{2}$

arcadas

$1020,83 \mathrm{~m}^{2}$ 


\section{VILLA SAREGO}

Proporções dos cômodos

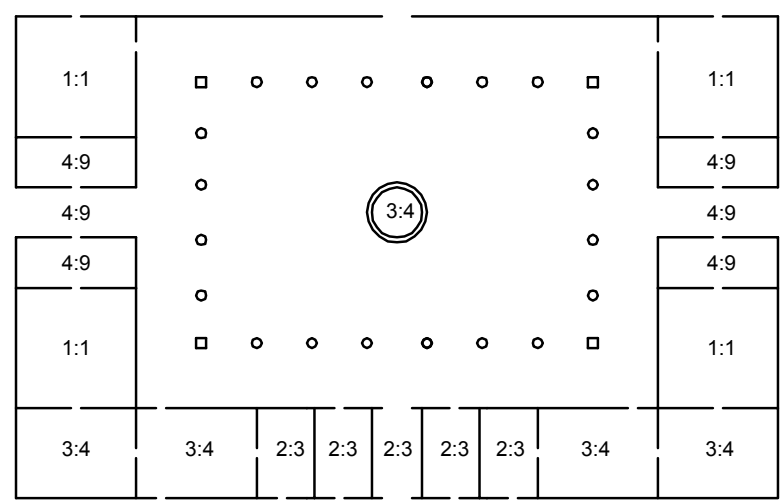

APARTAMENTOS - Tamanhos dos cômodos
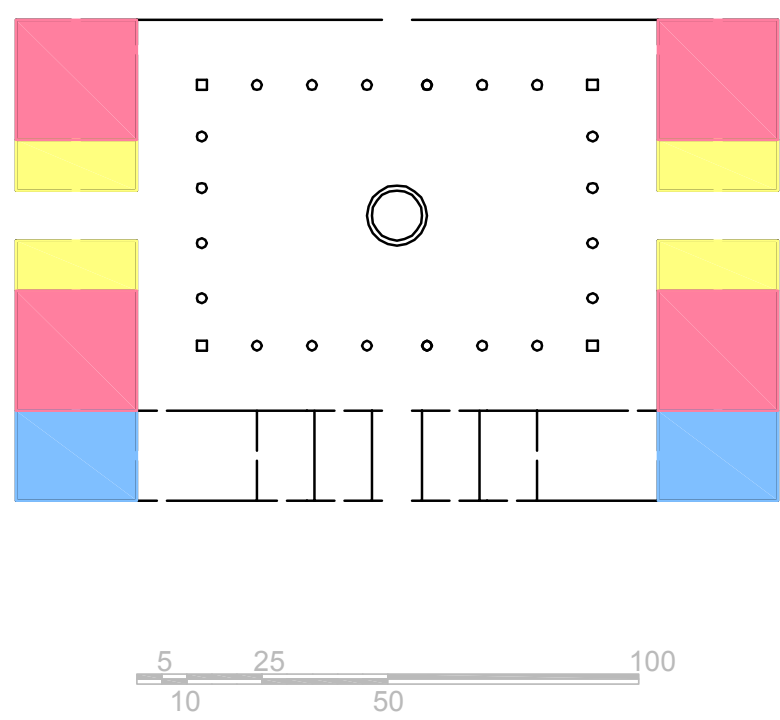

pequeno

médio

grande 
VILLA SAREGO MIGA

ÁREAS - Setores
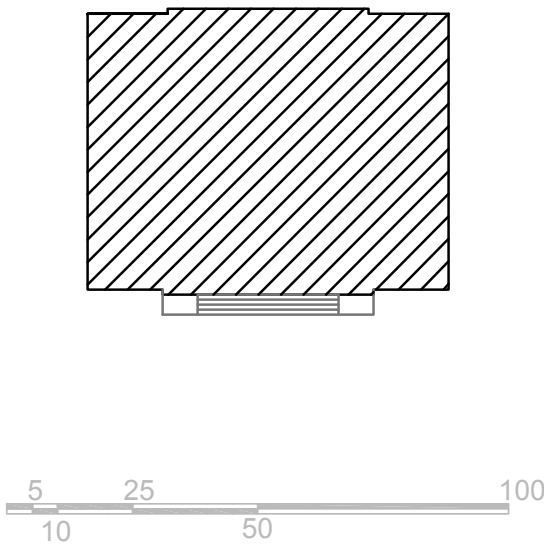

casa
$515,15 m^{2}$ 
Proporções dos cômodos

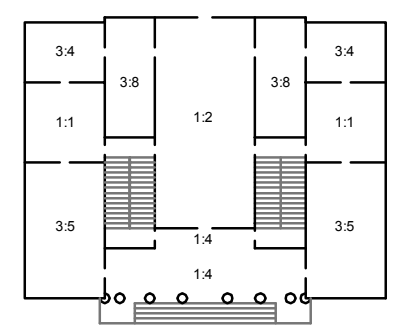

APARTAMENTOS - Tamanhos dos cômodos
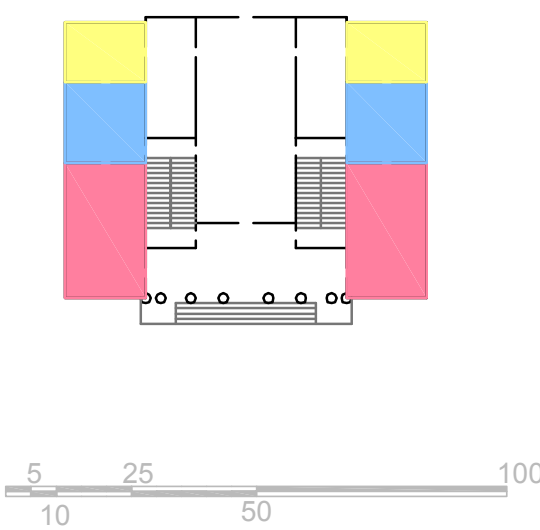

pequeno

médio

grande 

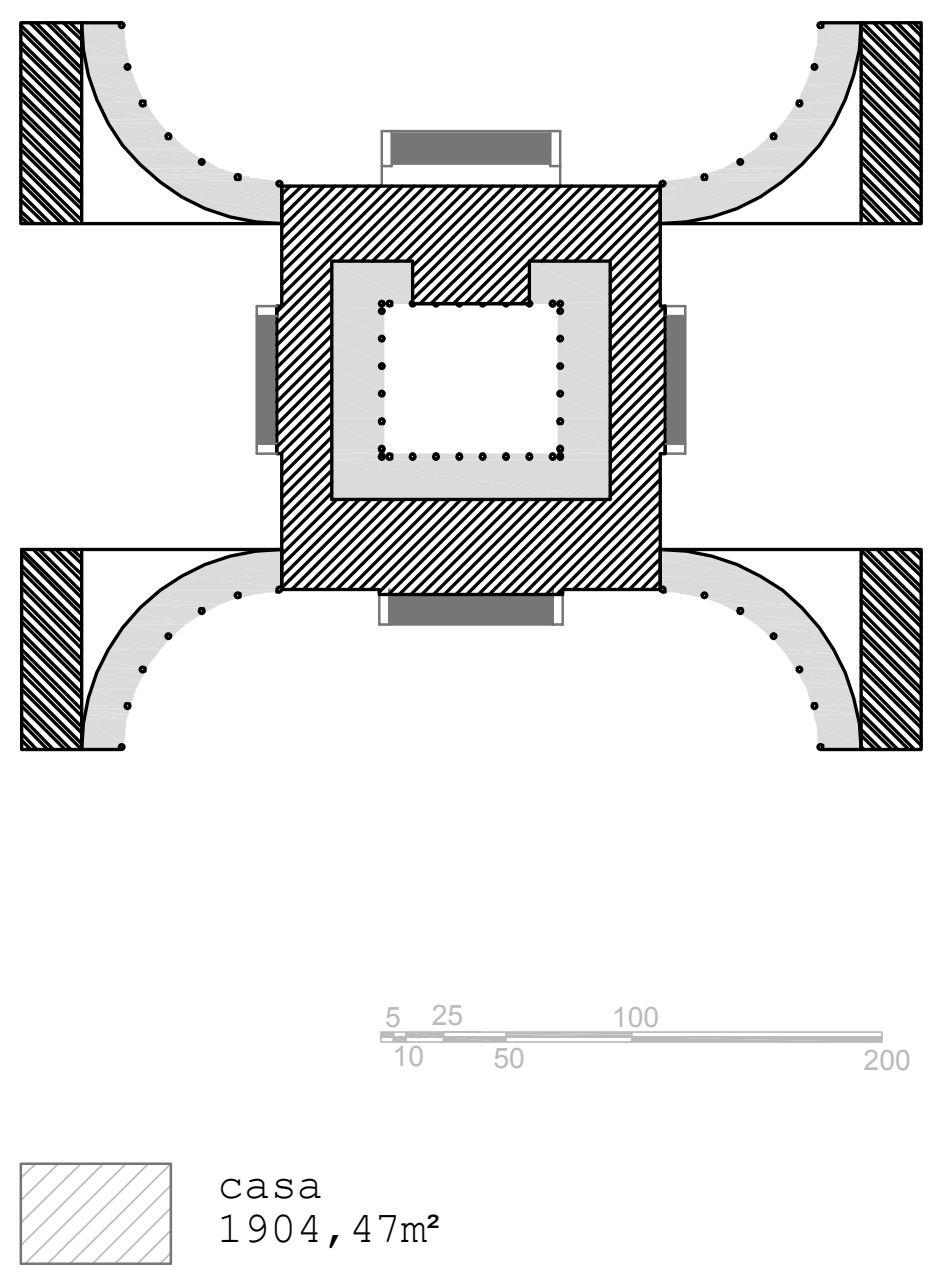

casa

$1904,47 \mathrm{~m}^{2}$

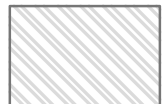

barchessa

$978,80 \mathrm{~m}^{2}$

arcadas

$962,47 \mathrm{~m}^{2}$ 
Proporções dos cômodos

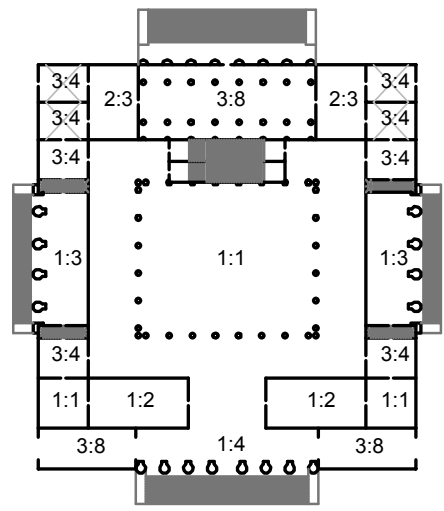

APARTAMENTOS - Tamanhos dos cômodos
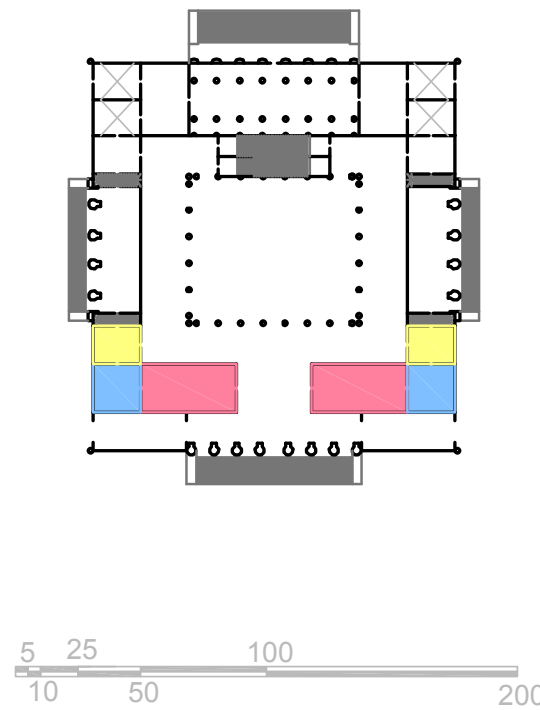

pequeno

médio

grande 